\title{
New Light on the Relationship between the Montecitorio Obelisk and Ara Pacis of Augustus
}

\author{
BERNARD FRISCHER, Indiana University, USA \\ JOHN POLLINI with NICHOLAS CIPOLLA, University of Southern California, USA \\ GIUSEPPINA CAPRIOTTI, Centro Archeologico Italiano, Cairo \\ JACKIE MURRAY, University of Kentucky, USA \\ MOLLY SWETNAM-BURLAND, William and Mary College, USA \\ KARL GALINSKY, University of Texas, USA \\ CHRYSTINA HÄUBER, Ludwig-Maximilians-Universität München, Germany \\ JOHN MILLER, University of Virginia, USA \\ MICHELE R. SALZMAN, University of California, Riverside, USA \\ JOHN FILLWALK, Ball State University, USA \\ MATTHEW R. BRENNAN, Indiana University, USA
}

The article takes as its point of departure recent work [Frischer forthcoming] critiquing the theory of Edmund Buchner about the relationship of the gnomonical instrument known as the Horologium Augusti and the Ara Pacis Augustae. As a result of this critique, the Montecitorio Obelisk could be situated with greater precision on the map of the city. A computer simulation showed that Buchner erred in positing that the shadow of the Montecitorio Obelisk went into the center of the Ara Pacis on Augustus' birthday. In this article, computer simulations are used to develop a post-Buchnerian interpretation of the relationship of the obelisk and altar. Over 230 hitherto unrecognized solar and shadow alignments are reported. The first part of the article defines four zones around the monuments where the solar and shadows observations were made. In the second part of the article, specialists interpret the significance of the annual solar and shadow spectacle from various points of view. The conclusion synthesizes the results, arguing that the monuments were intentionally aligned and situated in order to propagate the same message as the one inscribed on two sides of the Montecitorio Obelisk [CIL 6.702 = ILS 91]: that Augustus was a devoted worshipper of the sun god (Sol), who brings Rome victory in time of war, and prosperity in time of peace through his earthly representative, the emperor.

Key words:

Horologium Augusti, Montecitorio Obelisk, Ara Pacis Augustae, Unity, Stellarium, Archaeoastronomy.

SDH Reference:

Bernard Frischer et al. 2017. New Light on the Relationship of the Montecitorio Obelisk and the Ara Pacis of Augustus. SDH, 1, 1, Article 2 (March 2017), 105 pages.

DOI : $10.14434 / \mathrm{sdh} . \mathrm{V} 1 \mathrm{i} 1.23331$

First author's address: Bernard Frischer, Department of Informatics, Indiana University, 901 E. $10^{\text {th }}$ St., Bloomington, IN, USA 47408; email: bernard.d.frischer@gmail.com

Permission to make digital or hardcopies of part or all of this work is granted without fee according to the open access policy of SDH. (C) 2017 SDH Open Access Journal 


\title{
1. INTRODUCTION
}

\author{
Bernard Frischer ${ }^{1}$
}

lucem redde tuae, dux bone, patriae: / instar veris enim voltus ubi tuus / adfulsit populo, gratior it dies / et soles melius nitent.... (Horace, Odes 4.5.5-8)

From 13 to $9 \mathrm{BC}$ Augustus initiated projects in the Northern Campus Martius to erect the Ara Pacis, Montecitorio Obelisk, and the gnomonical device generally known as the Horologium Augusti. ${ }^{2}$ The projects had two motivations closely related to the two ways we can couple the monuments: obelisk-gnomonical device and obelisk-Ara Pacis. The obelisk-gnomonical device pair is functionally bound, serving the purposes of accurate time-keeping. The obelisk supported a sphere on a rod attached to the top of its pyramidion, and the shadow of the sphere hit a crosshatch inscribed on the meridian line at local noon each day of the year. The obelisk-Ara Pacis pair appears to have served the purpose of expressing the symbolism of imperial ideology, since the two monuments are visually bound but have no functional connection. They have a similar orientation, and the obelisk stands athwart an extension westward of the altar's axis of symmetry. In recent years, the attention of scholars has been concentrated more on the first than on the second pair.

This paper shifts the focus to the second pair and its motivation. It has two goals: to present a series of recently discovered solar and shadow axial alignments between the sun, the Ara Pacis, and the Montecitorio Obelisk that could be seen in the Campus Martius and Campus Agrippae during the reign of Augustus and beyond (for the location of these monuments, see the map on figure 1), and to interpret these alignments from various, mutually reinforcing points of view. We shall argue that the major motivation in erecting the monuments and siting them as they were was to create a recurrent sun and shadow spectacle that would have impressed the

\footnotetext{
${ }^{1}$ I am pleased to acknowledge that the research project on which I report in this paper was supported by the following: Zukunftskolleg, University of Konstanz; School of Informatics and Computing, Indiana University; the Netherlands Institute for Advanced Study in the Humanities and Social Sciences; the National Science Foundation (grant \#IIS-1014956). I take this opportunity to thank Francesco Prosperetti, Superintendent of the Soprintendenza Speciale per il Colosseo, il MNR e l'Area Archeologica di Roma, for permission to take geological cores and to pursue campaigns of ground penetrating radar in the area of the Campus Martius where the Horologium Augusti is suspected to have extended. For her support and cooperation, I am grateful to Marta Baumgartner, the Superintendency's official responsible for the area in question. I am indebted to Marina Sapelli Ragni and Anna Maria Reggiani, the members of the Scientific Advisory Committee for this project, for giving so generously of their time, advice, and insights. I wish to thank the following for their indispensable help in researching this article: Paolo Albèri Auber, Maria Elena Bertoldi, Heinz Beste, Michele Bilancia, Ralf Bill, Matthew R. Brennan, Jane Crawford, David Dearborn, Stefano Floris, Egbert Friedrich, Guido Giordano, Chrystina Häuber, Robert Hannah, Lothar Haselberger, Paul Humphreys, Günter Leonhardt, Paolo Liverani, Frans Maes, Ismini Miliaresis, Adalberto Ottati, Alberto Pichardo, Marco Ricci, Pietro Roccasecca, Rosella Roccasecca, Orietta Rossini, Michael Schütz, Claudio Soccodato, Magda La Torre, Giuseppe Tosti, Vance Tiede, Ursula Vedder, and Georg Zotti. I express my deep appreciation to Sig. Giuseppe Brunelli for permission to visit, survey, and take a core through the section of the meridian located in the basement of the building he owns at Via di Campo Marzio 48, Rome. I thank Sig. Brunelli's staff, especially Carla Coglitore and Giuseppe Cantiello, for their help and cooperation in arranging many visits to the site. I am grateful to Christof Schuler, Director of the Kommission für Alte Geschichte und Epigraphik of the German Archaeological Institute, Munich, for permission to consult the Edmund Buchner Archive and to publish the archival materials used in this article; and to Ortwin Daly, Director of the German Archaeological Institute, Rome, for permission to consult Edmund Buchner's geological cores as well as documents in the Friedrich Rakob Archive. Finally, I am happy to acknowledge the contributions made by the three anonymous referees of this paper. They are clearly highly informed, qualified, and perceptive readers, and their input has improved this paper in numerous ways. Peer review works!

${ }^{2}$ Hereafter also called the "gnomonical instrument," "gnomonical device," or "calendrical device". The Latin nomenclature used for the device is either Horologium or Solarium. All these terms are used interchangeably in this article.
} 
ancient viewer with the emperor's learning, power, and religious commitment to Sol, the god to whom he explicitly dedicated the obelisk [CIL $6.702=$ ILS 91; for the text, see n. 56 and the end of this article].

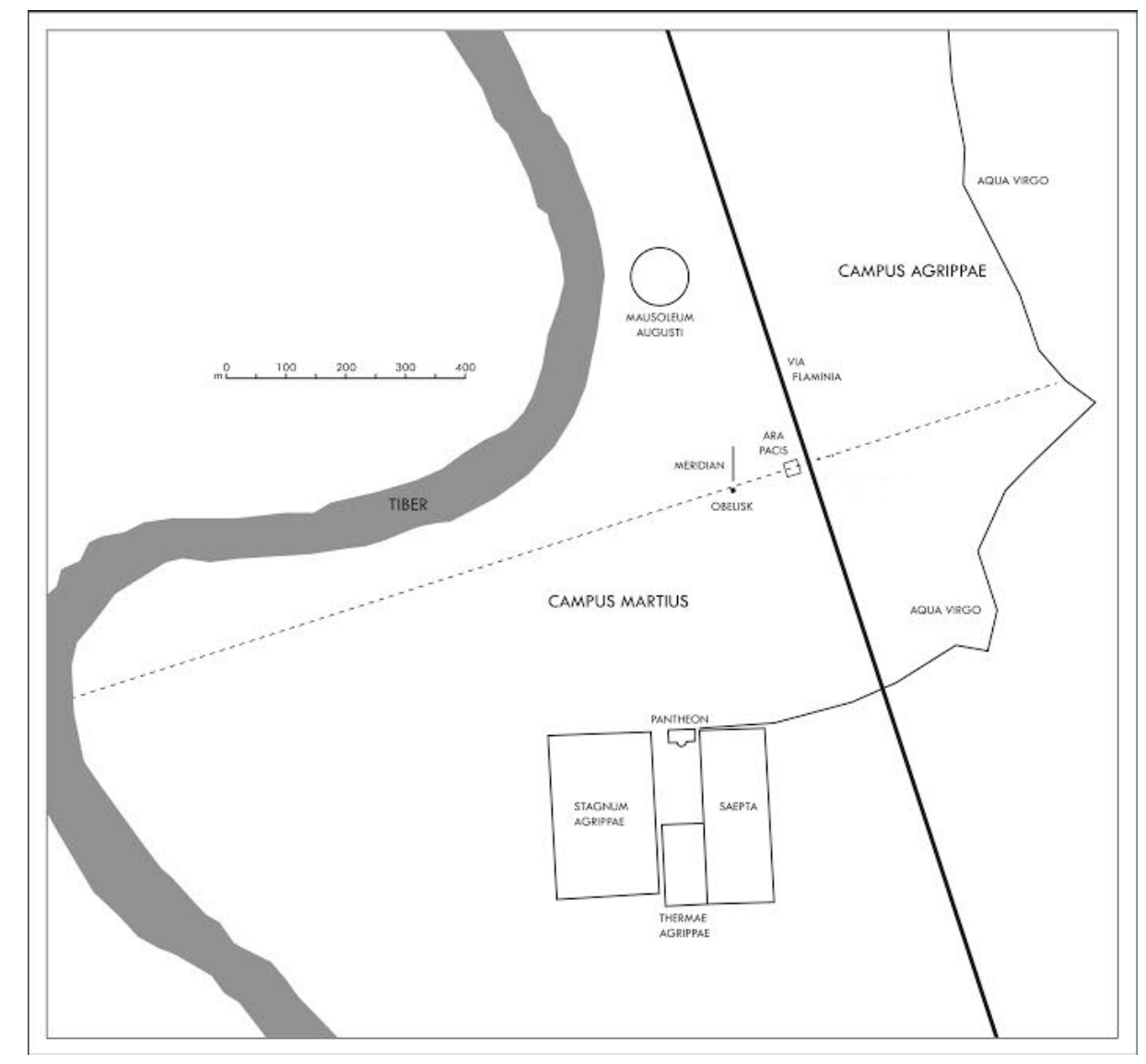

Figure 1. Map of the northern Campus Martius, ca. 9 BC, showing monuments discussed in this article. Scale in meters. Source: Matthew R. Brennan, Virtual World Heritage Laboratory, Indiana University.

The background of our study is the theory of Edmund Buchner about the Horologium Augusti and its reception by scholars since the first version of the theory was published in 1976. In a recent publication [Frischer forthcoming], we have traced the development of Buchner's theory and have brought to bear new evidence (partly found among the unpublished materials in Buchner's archive now available for consultation in the Commission for Ancient History and Epigraphy in Munich) casting doubt on its validity. In this article, we take our conclusions in that paper as the point of departure for a new, post-Buchnerian approach to the problem. Given the central role played by Buchner's ideas since his first publication on the problem in 1976, it will be useful to begin by giving a summary of Buchner's theory and our stance toward it.

Buchner's theory had three elements: (a) the siting of the Ara Pacis, Montecitorio Obelisk, and the gnomonical instrument; (b) the environmental effect caused by the siting; (c) the ideological message implicit in the environmental effect. Regarding element (a), Bucher 1976 proposed that the gnomonical instrument was a horizontal sundial inscribed on a monumental pavement; in the 1980s and 1990s, Buchner's thinking about 
the exact design of the instrument evolved. Several of Buchner's critics in the past ten years have interpreted the gnomonical instrument as a meridian [Heslin 2007; Albèri Auber 2011-2012; Albèri Auber 2014]. At present, all we may safely say is that new fieldwork is required to resolve the debate about this matter.

Buchner thought that the environmental effect (element b) was the projection of the shadow of the obelisk into ${ }^{3}$ the center of the Ara Pacis on Augustus' birthday (September 23). We have shown elsewhere that, once we correct Buchner's errors about the siting and phasing of the gnomonic device, the obelisk's shadow does not penetrate into the center of the Ara Pacis on that date. We also mooted the possibility that what was as relevant as the projection of the obelisk's shadow onto the altar was the appearance of the sun's disk centered on the top of the obelisk. We preliminarily reported that we had observed a single solar axial alignment observed east of the Ara Pacis on October 9 each year, and we suggested that this alignment might have been decisive in the siting of the monuments [Frischer and Fillwalk 2014: 88]. In a more recent article, we noted that further research has revealed that similar alignments occur on at least 224 days of the year, making it unlikely that a single date such as October 9 was driving the arrangement of the monuments. We promised to follow up in a subsequent article with the details and a new interpretation, which we hereby do. We will also propose a new interpretation of the environmental effect based on the idea that what was significant was the cumulative effect of the sun and shadow spectacle staged by Augustus each year in the new public parks in the northern Campus Martius and the adjacent Campus Agrippae.

In an earlier publication, we also noted that attributing this role to the sun's disk should not be ruled out of consideration for the simple reason that "everyone knows you shouldn't look at the sun." In fact, the modern understanding of the risk of solar retinitis caused by looking at the sun was not something known to medical science before 1894; ${ }^{4}$ and that naked eye observation of the sun is attested for millennia [Vázquez and Vaquero 2009]. Here we also note that we have evidence of such observation from ancient Rome: in the period of ca. 450 to $260 \mathrm{BC}$, an attendant of the consuls had the duty of observing the sun prior to publicly declaring the noon hour and last hour of business in the Roman Forum [Pliny, HN 7.60]. Aulus Gellius [7.4] recounts the story of the torture of Marcus Atilius Regulus by the Carthaginians during the First Punic War. We are told that Regulus, who served as a famous exemplum virtutis to generations of Roman schoolchildren, was imprisoned in a dark dungeon and then, as part of the regimen of torture to which he was subjected, he was brought outside and forced to gaze directly at the sun with his eyelids forced apart and sewn open. We are not, however, told that, as a result of this mistreatment, Regulus lost his vision. ${ }^{5}$ In other words, we have no evidence that the Romans connected gazing at the sun with blindness. So there is no obvious reason that would have prevented the Augustan designer from basing the alignment of the Ara Pacis and obelisk on the sun's disk as well as on the obelisk's shadow projected onto the altar.

Buchner thought that the message transmitted by the effect (element c) was that Augustus was natus ad pacem. In this article, we work out the interpretative consequences of the numerous solar and shadow alignments we

\footnotetext{
${ }^{3}$ Recently, there has been some debate about whether Buchner's theory was that the shadow would go "into" the center of the Ara Pacis on Augustus' birthday or merely "toward” the center. For the latter view, see Haselberger 2014a: 179. We have presented clear evidence from Buchner $(\dagger 2011)$ himself that he meant the former (Frischer forthcoming: section 2 ).

${ }^{4}$ Mackay 1894; note especially the following on the article's first page: “...one is surprised to find how few cases of ocular injury from such exposure have been recorded.” See Frischer and Fillwalk 2014: 88.

${ }^{5}$ I thank Chris Johanson for bringing this passage to my attention. On Tubero, the late-republic historian, as Gellius' source, see Hosius 1903: xxxvii.
} 
have discovered and propose a new message. We should note at this point that, although we clearly do not agree with some details of Edmund Buchner's theory, we acknowledge his undisputed importance in both defining the problem and undertaking the fieldwork that, among other things, brought to light part of the meridian under the building at Via di Campo Marzio 48 and also produced evidence about where the obelisk stood beneath the building at Piazza del Parlamento 3.

This paper has three main sections: (1) a description of the computer simulations, including their archaeological and astronomical basis, and the solar and shadow alignments they revealed; (2) interpretations of the newly discovered alignments from various points of view; and (3) a final section with a summary and a conclusion in which we propose a new message implicit in the environmental effects.

\section{THE COMPUTER SIMULATIONS AND SOLAR ALIGNMENTS}

Bernard Frischer

The research reported here was undertaken with the aid of computer simulations of the northern Campus Martius in the period $9 \mathrm{BC}$ to $\mathrm{AD} 40 .{ }^{6} \mathrm{We}$ therefore begin with a description of the simulations and the related archaeological and celestial data incorporated in them.

\subsection{Archaeological data}

The simulations incorporate 3D digital reconstruction models of the Augustan Campus Martius between the Via Flaminia on the east and the Mausoleum of Augustus on the northwest and the Pantheon on the southwest. Also included is the portion of the Campus Agrippae across the Via Flaminia from the Ara Pacis. The features of the Pantheon, ${ }^{7}$ Mausoleum, and Via Flaminia still exist and thus can be put into the computer simulation with great confidence in the right place and at the right quota level. ${ }^{8}$ The Ara Pacis was surveyed by Moretti, who published a plan showing its footprint superimposed over the modern Palazzo Fiano-Almagià [Moretti 1948: vol. 2, fig. 36]. It can thus also be accurately situated in the simulation in terms of quota level and location.

The final component of the simulation is the Montecitorio obelisk. This monument was excavated in 1748 and restored and re-erected ca. $220 \mathrm{~m}$ to the south in $1792 .^{9}$ The mid-eighteenth century interventions were well described in Bandini 1750 but, unfortunately, they were not sufficiently documented cartographically to allow us to know exactly where the obelisk stood in terms of the modern city. What is certain is that the base, rotated $15^{\circ} 10^{\prime}$ off the cardinal points, ${ }^{10}$ was found beneath the modern building at Piazza del Parlamento 3, a building whose footprint is ca. $22.6 \times 23.5$ meters. Precise positioning of the obelisk within the building's perimeter thus requires an inferential method, whose results can be controlled by the data produced by unpublished corings

\footnotetext{
${ }^{6}$ The time period reflects the fact that the Ara Pacis and Montecitorio obelisk were completed by 9 BC and, according to Pliny $[H N$ 36.73] the gnomonical device ceased to render accurate time by ca. 40 AD.

${ }^{7}$ For the temple's design in the Augustan period, we have followed the indications of Virgili and Battistelli 1999; Virgili $2006: 167$.

${ }^{8}$ For the footprint and orientation of the Augustan Pantheon, see Virgili and Battistelli 1999: 137-154.

${ }^{9}$ Ciampini 2004: 143. For the measurement, we relied on Google Earth. On the high accuracy of Google Earth for surveys in the city of Rome, see Pulighe, Baiocchi, and Lupia 2015.

${ }^{10}$ See Stuart in Bandini 1750: LXXIII; n. 110 in Frischer forthcoming.
} 
undertaken by Edmund Buchner. The fact that a gnomon must be positioned due south (in the northern hemisphere) of a meridian allows us to infer with precision the east-west position (longitude) of the obelisk, since we know the longitude of the part of the meridian found by Buchner under the modern building at Via di Campo Marzio 48. ${ }^{11}$ The obelisk's north-south position (latitude) is less certain. In principle, it could be calculated if we knew the exact height of the center of the sphere above the quota level of the meridian, but we do not. Recent estimates vary from 29.6/30.0 meters [Albèri Auber 2014: 73; Albèri Auber 2016] to 30.7 meters [Schütz 2014: 44]. For example, on the equinoxes, as compared to an obelisk with sphere $29.6 \mathrm{~m}$ high, a sphere whose center is $30.6 \mathrm{~m}$ off the pavement necessitates a movement of the obelisk ca. $90 \mathrm{~m}$ to the south on the extension of the meridian line. ${ }^{12}$ Additional evidence about the location of the obelisk derivable from Buchner's unpublished corings in the basement of the building at Piazza del Parlamento 3 is presented in Frischer forthcoming, section 9. The corings support our placement of the base of the obelisk. Settling these matters is critical for understanding the timepiece, but, as our stress tests will show (see section 2.5), it is not so for defining the alignments between the Ara Pacis, obelisk, and the sun.

Regarding the controversial matter of whether Novius Facundus' project to use the obelisk as the support for the sphere was planned right from the start or was a later idea, ${ }^{13}$ we are agnostic for two reasons. First, even if the sphere (or, finial) was part of the original plan, its umbral shadow could not reach as far as the Ara Pacis, only its much fainter penumbral shadow. Secondly, the shadow that concerns us is the umbral shadow of the trunk of the obelisk, which, without doubt, would have reached as far as the Ara Pacis. Thus, the answer to the question of whether or not, right from the beginning, there was a finial atop the obelisk has no bearing on the new theory we develop in this article.

Finally, we note that there is no archaeological evidence that the western extension of the axis of symmetry of the Ara Pacis, running from the altar toward the obelisk and beyond, was ever paved. ${ }^{14} \mathrm{We}$ base this statement on the absence of finds of ancient paving in the Carta Archeologica di Roma. The simulations we created have a pathway which is hypothetically restored; our theory does not depend on the validity of the hypothesis, only on the absence of any structure obstructing the movement or the the sightline from the Ara Pacis to the obelisk and beyond. As we will see, this is the case. From the east entrance of the Ara Pacis to the Via Flaminia, we do

\footnotetext{
${ }^{11}$ See Frischer forthcoming, where two independent surveys are reported, both of which agree with the surveys by Bill and Leonhardt found in the Buchner Archive. So the exact position on the modern map of the meridian discovered by Buchner is not in dispute. We note here that Ottati's survey, reported in Frischer forthcoming, and Bill's survey (unpublished document, Buchner Archive) agree in finding that the meridian line excavated by Buchner runs almost exactly due north: any error is less than one-half a degree. Valerio Baiocchi is presently engaged in research trying to define the deviation from geographic north with even more precision; he agrees that the error is under one-half degree (personal communication to B. Frischer, November 5, 2016), an amount which gnomonist Paolo Albèri Auber describes as trivial and having no bearing on the ability of the gnomonical device to operate reliably (personal communication to B. Frischer, July 2015).

12 The reader can confirm this observation by positioning himself just south of the equinoctial line, setting the time for March 22,9 BC, at 11.30 (i.e., 11:18 am GMT/UHT), and using the sliders on Model 1 labeled Obelisk Height Adjust and Obelisk North/South to change the height of the obelisk by $+1.1 \mathrm{~m}$ and its position $-.90 \mathrm{~m}$.

${ }^{13}$ On the basis of the obelisk's orientation, rotated 15 degrees countercloswise from true north, Stuart 1750: LXXIV first proposed the two-phase theory, which Bandini 1750: 72 accepted. This theory has been revived in modern times by Schütz 2011: 82-83 (=Schütz 2014: 47-48), Albèri Auber 2014: 69; Heslin forthcoming: 14. In contrast, Buchner assumed that the gnomon was planned from the beginning and the project was unitary, a position recently argued by Pollini and Cipolla 2014: 54 and also below in this article. Other co-authors disagree, but the matter is tangential to our main argument and so will left in abeyance here.

${ }_{14}$ There has been speculation to the effect that it was, e.g., in the physical model of the area on display in the Museum of the Ara Pacis in Rome.
} 
have evidence that the axial line was paved. ${ }^{15}$ Farther east, across the Via Flaminia in the Campus Agrippae, we have no evidence of a paved road or of obstructions along our axial line for some distance. The first known obstruction occurred ca. 450 meters east of the Ara Pacis, when the axial line crossed the Aqua Virgo, which is reported by the Carta Archeologica di Roma to have been running above ground at that point. ${ }^{16}$ The intersection is farther to the east than the area we studied and hence has no impact on our results.

In general, we argue that elements (b) and (c) of Buchner's theory are in logical and practical terms independent of element (a). Whether the gnomonical device was a horizontal sundial or a meridian has no necessary relationship to the nature and purpose of the alignment between the Ara Pacis and the obelisk. As long as the issues of the exact height and position of the obelisk are settled within the current range under debate, the alignments that we report here will remain valid.

\subsection{Computer simulations}

Using these archaeological data, we created a number of simulations of the northern Campus Martius in the time of Augustus. What may be called the "base simulation" differed from the others in that it has a gnomon that is $29.6 \mathrm{~m}$ off the level of the meridian. We have one version of the base simulation in the game engine Unity, first created in 2012 (see Model 1), and a second in the planetarium software Stellarium, created in 2015. ${ }^{17}$ Besides our base simulation in Stellarium, we also used that software to create variants to support empirical studies necessitated by research: in one, the gnomon is set at $30.7 \mathrm{~m}$ off the level of the meridian, and the obelisk is accordingly moved ca. $1 \mathrm{~m}$ to the south. In another, we add to the base Stellarium simulation the Ara Providentiae in the position hypothesized by Coarelli 1983 (referencing the work of Scheid and Broise 1980). All of these simulations allow the user freely to explore the scene, the northern Campus Martius in the Augustan age, and to change the position of the sun on a minute-by-minute basis for the period $9 \mathrm{BC}$ to 40 AD. Each sets the camera at approximately average adult eye level-the Unity simulation at $1.58 \mathrm{~m}$ off the virtual ground, the Stellarium simulation at $1.65 \mathrm{~m} .{ }^{18}$

The Unity simulation published here as "Model 1" supports various views of the scene. In "Ground View," the user can freely explore the entire area contained within the model. In "Ara Pacis View", the user is locked on the line of axial symmetry of the Ara Pacis, and the camera is positioned at $1.58 \mathrm{~m}$ off the ground to approximate adult human vision. This facilitated studies of alignments involving the sun's disk, since it was found in "ground view" that the observer could easily deceive himself and create false alignments by moving even as little as a meter off axis. "Top View" facilitates studies of the obelisk's shadow, since the viewer can easily see the entire sweep of the shadow cast by the obelisk within the zone modeled. The clock in the Unity simulation works in units of one minute of equinoctial time. The Unity simulation also includes various resources that can be superimposed over the Top View, including a contemporary aerial photograph of the zone, the city's cadastral map, a drawing of the segment of the meridian found by Buchner under the building at Via di Campo Marzio 48, and the plan of the foundations of the Ara Pacis published by Moretti. Finally, the Unity simulation

\footnotetext{
${ }^{15}$ Carta archeologica di Roma: no. 85 on the map.

${ }^{16}$ In the modern city, the aqueduct ran between the Via Due Macelli and the Via Gregoriana. The distance from the east entrance of the Ara Pacis given above is based on using the measurement tool in Google Maps.

${ }^{17}$ http://stellarium.org/ Our Stellarium model can be downloaded here; for instructions on how to use it, see: http://www.stellarium.org/wiki/index.php/3D_Sceneries_plugin

${ }^{18} \mathrm{See}$ http://www.ergotron.com/Portals/0/literature/whitePapers/english/ergonomics arms data.pdf
} 
supports research on the impact that a change in the height and position of the obelisk would have on the environmental effects of the obelisk's shadow and the position of the sun in the sky. The obelisk can be raised or lowered from its default value of $29.6 \mathrm{~m}$ by as much as $2.0 \mathrm{~m}$. It can similarly be moved as much as $2.0 \mathrm{~m}$ north or south from its default position on an extension of the line of axial symmetry of the Ara Pacis. We used these features to support various experiments, or "stress tests," to understand if changes in the height or position of the obelisk would affect our results. This matter is discussed below in section 2.5. Here we may note that the ability of simulations to support such empirical work is a powerful new tool in the toolkit of archaeology [cf. Frischer forthcoming, section 15].

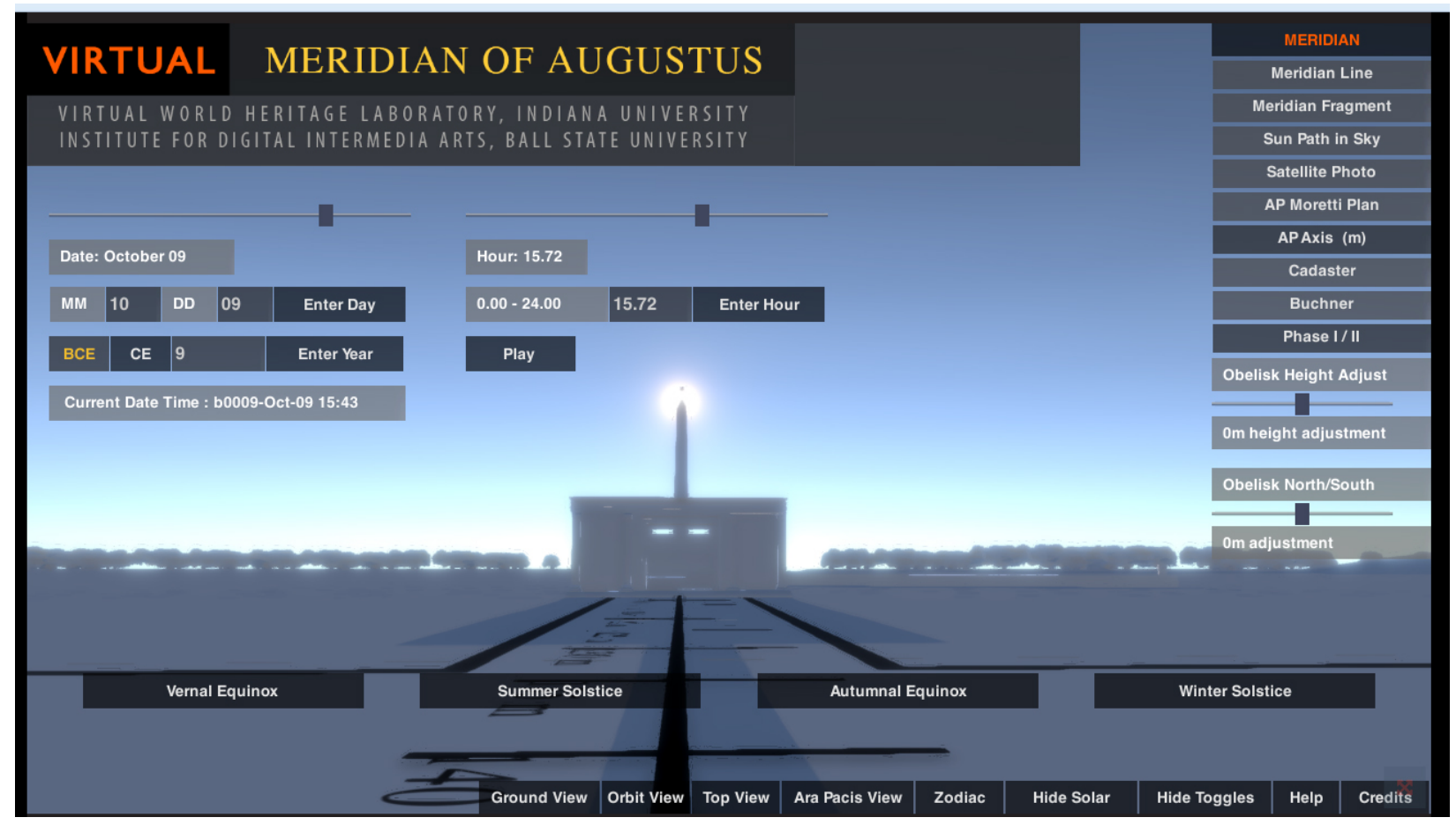

Model 1. Screen shot of the Unity version of the Virtual Meridian of Augustus. Click here to run it interactively in a browser such as Chrome, Firefox, Opera, or Safari, which supports WebGL. For instructions on how to use the model, see Appendix I. Source: Institute for Intermedia Arts, Ball State University, in collaboration with the Virtual World Heritage Laboratory, Indiana University.

The Stellarium simulation was a resource whose main purpose was to offer independent confirmation of the alignments uncovered by the Unity simulation while also improving precision. It, too, supports free movement through the area modeled. It has one advantage and one disadvantage as compared to the Unity simulation. On the positive side, Stellarium prints to the screen the camera's current coordinates and calculates time to the second (features lacking in the Unity simulation), and this increases the precision with which terrestrial positional data for a given alignment can be defined and reported. In contrast, it is not currently possible in Stellarium to lock the camera to a fixed path, such as the line running between the midpoints of the Ara Pacis and Obelisk, as we did in the Unity version. Thus, although Stellarium reports our position with greater accuracy than is the case with Unity, we are less certain that we are exactly on the line tying together the midpoints. A final advantage of Stellarium was not directly relevant to our study but should be mentioned: it has a correctly rendered dynamic night sky, which is a feature not currently available in the Unity simulation. 
We plan to use this affordance to investigate possible alignments of the monuments with the visible planets, the moon, and the constellations.

The two simulations provided independent confirmation of each other's solar alignments because each uses a different method in calculating the earth's ephemerides (or, if you will, the sun's apparent movement across the sky over time). Stellarium uses the method known as VSOP87; ${ }^{19}$ Unity uses the JPL Development Ephemeris (JPL DE431). ${ }^{20}$ Thus, in using the same archaeological data to find solar alignments calculated in two different ways, we were able to replicate our results before accepting them as valid and reporting them here.

\subsection{Rules of investigation}

Before reporting the solar alignments we observed in both simulations, we make explicit the rules of investigation we applied. Rules are useful for two reasons: in the area studied, there are almost twelve billion possible solar observations one can make during the course of a year. ${ }^{21}$ So having rules was useful, first of all, to quantify the scope of the problem and to reduce the number of possible solutions to something more manageable. Secondly, it is not clear from an ancient source whether the alignments reported here were ever noticed and, if so, what, exactly, constituted the preconditions to be fulfilled before an alignment could be said to have occurred. Where did you have to stand? What were you supposed to see? Thus, the second use of rules was to define as clearly as we can what we consider to be an alignment. This allowed us to be consistent and also to invite our readers to judge whether or not they consider our approach reasonable. Regarding the absence of an ancient source explicitly discussing an alignment, we should simply note that the surviving documentation is scarce. In fact, the most informative source-Pliny HN 36.71-73-does not treat the obelisk-Ara Pacis alignment, only the obelisk in relation to the gnomonical instrument. Thus, the absence of explicit attestation that the alignments reported here were noticed and considered important in antiquity cannot fairly be taken as evidence against the project, initiated by Buchner 1976 and continued by other scholars, to find and interpret alignments between the altar and obelisk. It is not as if we have many ancient reports about the Ara Pacis and obelisk, none of which mention their alignment. In fact, we have no ancient source at all discussing one monument in reference to the other, and we have precious few about either monument taken alone. ${ }^{22}$

The rules we use derive, in part, from those implicitly observed by earlier scholars writing about the Buchner thesis, starting with Edmund Buchner himself. For Buchner, the rule was that the shadow of the obelisk had to enter into the middle of the Ara Pacis. This was a rather vague definition: he did not state what the length of the shadow would be, whether he was referring to the umbral or penumbral shadow (or both), where, exactly, the shadow entered and how far it penetrated into the interior of the altar. He also did not specify where the ancient viewer should, ideally, have stood to watch this spectacle. In pointing out these issues, we are not

\footnotetext{
${ }^{19}$ See www.stellarium.org/wiki/index.php/Precision

${ }^{20}$ https://en.wikipedia.org/wiki/Jet_Propulsion_Laboratory_Development_Ephemeris

${ }^{21}$ Here is how the above estimate was calculated. The area of interest is $150 \mathrm{~m}$ in a N-S direction and $600 \mathrm{~m}$ in an E-W direction. Consider that one's view of the scene defined by the sun in the sky and the monuments on the ground noticeably shifts every time one moves out of a zone that measures 1 x 1 meter. Let us call such a zone an "observational unit." Then there are 90,000 such units in the area of interest (i.e., $600 * 150$ ). Next, consider that the sun appears to be moving through the sky at a rate of 1 solar diameter every 2.1 minutes. Let us call two minutes a "solar unit." Each movement of the sun by one unit perceptibly changes the scene. There are ca. 263,000 minutes of daylight each year, or 131,500 solar units. So the total number of possible observations in our area of interest is: (number of observational units) $*$ (number of solar units) $=90,000 * 131,500=11.835$ billion.

${ }^{22}$ For a collection of ancient sources mentioning the Ara Pacis, see Centanni and Cianni 2007.
} 
necessarily making a criticism: clearly, the shadow effect is quite subjective, and scientific measurements are not to be expected.

In the case of the solar alignments of interest to us, this is all the more the case in that no one can look at the sun for more than a few seconds (of course, today we know that you should never look at the sun so readers are urged not to try doing this), and this does not allow enough time for more than a vague impression to form in the observer's mind. Moreover, the eyes tend to blur when looking at the sun high in the sky, and this also works against precise observation. It should be noted that the finial atop the obelisk eclipsed the sun, at least in part ${ }^{23}$ and this would have helped protect the eyes and reduced the blurring. That said, in this study we have striven to make our observations as precise as possible, even if the degree of precision we achieved was in excess of what was required. This was motivated less by a pedantic desire for accuracy than by the desire to give exact times and geocoordinates so that the reader can use the simulations we publish here to attempt to replicate any or all of the hundreds of observations found in our tables in the appendix.

When the results of our simulations are checked by readers, we claim an accuracy of \pm 30 minutes and \pm 10 meters. Greater precision than this is not possible given the tools available, the remaining uncertainties about the archaeological facts on the ground, and the enormous passage of time. Moreover, greater precision (however desirable as a scientific end in itself) is not pertinent to our argument. We are interested here in the fact that on a certain day, there was a solar alignment vieweable by someone standing somewhere along the axial line at some moment in time. The spatio-temporal coordinates we give have the purpose of facilitating the reader's ability to control the results we report by consulting the tables and harmonizing the simulation on their screens to our settings. With this background in mind, let us now state the rules of investigation that we used.

The first rule is axiality. The observer must stand on an extension of the line of axial symmetry of the Ara Pacis, whether to the east or to the west. The monuments as well as the obelisk's shadow or the sun must also appear to be in axial alignment. Applying this rule sharply reduces the area of interest (from $600 \times 150 \mathrm{~m}$ to $600 \times 1$ $\mathrm{m}$ ) and thereby reduces the number of possible observations from the intial ca. 12 billion to ca. 79 million. We note here that axiality has long been recognized to be a hallmark of Roman architectural design. ${ }^{24}$

Next, there is the rule of superimposition. The environmental effect (whether, in this case, the obelisk's shadow or the sun's disk) must appear to be superimposed over or behind one of the monuments of interest. Superimposition was stressed by Buchner: the shadow of the obelisk was only significant when it was projected into the middle of the Ara Pacis. In terms of a sun-obelisk alignment, our report is based on the assumption that the desired effect was the obelisk's pyramidion centered on the sun's disk (for a photograph of how this

\footnotetext{
${ }^{23}$ We do not know the diameter of the finial, so we cannot tell whether it entirely or only partially eclipsed the sun (for how this appears today in the modern restoration see figure 2). Either way, because of atmospheric refraction, which (as can be seen in Model 1) greatly increases the sun's apparent diameter, the viewer could easily tell when he had achieved the maximum alignment of the sun with the top of the obelisk.

${ }^{24}$ Axiality, along with symmetry and frontality, is a hallmark of Roman architectural design. See, for example, in the older literature: von Gerkan 1924: 146-148, 160-161; Kaschnitz von Weinberg 1944: 89-128; Boethius 1935: 184f.; Boethius 1948; von Blanckenhagen 1954: 21; Brown 1967: 20, 27; Castagnoli 1971: 121; cf. the perceptive remark in Clarke 1991: 4: "Strangely, Vitruvius and other writers on the domus are silent on the subject of the fauces-atrium-tablinum axis, probably because it was such an obvious and invariant feature."
} 
appears today, see figure 2). ${ }^{25}$ That such an effect was considered by the Egyptians as particularly relevant to the sun cult is clear from the determinative of the sun tangent to the top of an obelisk (figure 3), which is found in some Fifth Dynasty texts and is used in connection with sun temples [Schäfer 1929; Bonnet 1952: 539; Ricke 165: 5]. We do not claim that knowledge of this determinative was available after the Fifth Dynasty, only that the sign is evidence of an early conception behind the symbolism of the obelisk. Later Egyptian and, indeed, Roman texts make it clear that the obelisk was thought to represent a sun beam [Quirke 2001; see also section 4 below]. It is a short step from that conception to the notion that the hierophany of the sun occurs when the sun is directly over its symbolic sun beam. That is a notion that was always implicit and which could be spontaneously reactivated from time to time, even if the Fifth Dynasty explicit association had long since been forgotten.

For the sun-Ara Pacis alignment, we assume that the desired effect was the appearance of the sun centered behind the Ara Pacis at some point after sunrise, as seen by someone standing to the west of the altar with the obelisk at his back. In Egypt, this recalls the hieroglyph known as the akhet, which is associated with sunrise over the horizon (see below, section 3.2). For the shadow alignment we follow Buchner in looking for the shadow of the obelisk (not of the sphere, whose umbral shadow would not have been salient to the distance of the west façade of the Ara Pacis) projected onto the center of the west façade of the altar. As we will see, application of this rule effects a further reduction of possible observations from approximately 79 million to under three hundred.

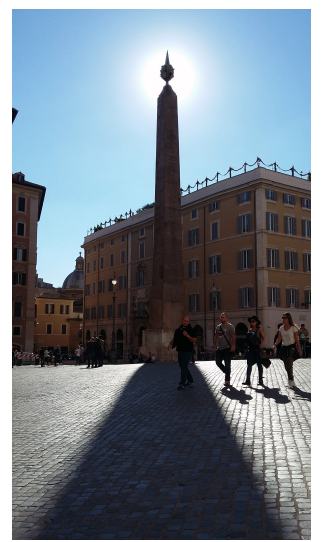

Figure 2. Sun atop and centered over Montecitorio obelisk. Source: photograph by Bernard Frischer.

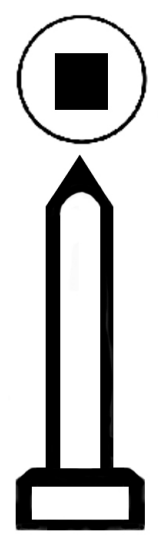

Figure 3. Determinative in Old Egyptian for a solar cult. Source: Bernard Frischer after Schäfer 1929: 721.

The third rule is spatial relatedness. Since the problem under study is the relationship of the obelisk and the altar, the obvious and most convincing explanations are those that put both monuments in a direct line of sight with each other, or else that require the observer to be positioned between both monuments. As an example of

\footnotetext{
${ }^{25}$ The alternatives to the finial-gnomon are: (1) the base of the sun's disk tangent to the top of the obelisk. This relationship will, however, vary according to the atmospheric refraction, something that does not affect the juxtaposition of the finial or tip of the obelisk and the center of the solar disk. (2) The tip of the pyramidion of the obelisk. While certainly possible, we consider this less likely since at the design stage, the height to the finial-gnomon was an exactly known quantity, whereas that to the top of the pyramidion may have been less certain.
} 
the latter, one may cite Buchner's interest in the obelisk's shadow projected onto the west façade of the Ara Pacis. This is something best seen by someone standing with the obelisk to his back in the area between the obelisk and the west façade. The first variant of spatial relatedness is called intervisibility; the second, interpositionality, or to use the geometric term, betweenness. ${ }^{26}$ In what follows, if a view is said to be intervisible, that means that it includes both the obelisk and the Ara Pacis; if it is called interpositional, that implies that the viewer must stand between the two monuments while looking at one of them. This rule has no impact on the statistical analysis of possible observations since it is, in effect, another way of formulating the first rule of axiality with reference to where the human observer is standing and gazing.

Finally, there is the fourth rule of frequency. The rule is also applied in two ways. If the environmental effect happens relatively infrequently throughout the year, then, when it occurs, it can strike observers as particularly compelling and worthy of note. This is clearly the case if the occurrence coincides with an appropriate cultural custom or event, such as a religious holiday or, as Buchner assumed, the emperor's birthday. Contrariwise, an effect that occurs very frequently can imply that the general phenomenon, apart from the specific cultural event(s) with which it may be associated, is the point that is being emphasized. Once again, application of this rule does not affect the number of possible observations; it pertains to how we interpret our observations.

Granted, there is a subjective factor in deciding what should be considered "rare" or "very frequent" and what not. In weighing the matter, we must bear in mind that, except for the solstices, the sun is in the same position in the sky on two days of the year, given the fact that it retraces its apparent path through the sky between one solstice and the other. This means that most alignments are likely to occur, at a minimum, not once per year but at least twice or, depending on the amount of space where the observer could conceivably have stood, some multiple of two.

As we have seen, Buchner assumed that rareness was the way this rule should be applied: he focused exclusively on Augustus' birthday, September 23. In doing so, he did not point out that the sun is in the same position on a corresponding date of the year, viz., March 23. The same can be said of an early critic of Buchner, Schütz, who proposed April 21 (Parilia) as the key date driving the alignment of the Ara Pacis, but who does not note that the sun is in the same position on August 27. ${ }^{27}$ Both Buchner and Schütz ought to have pointed out the second date and explained why they preferred the member of the date-pair they chose to emphasize. Finally, neither Buchner nor Schütz gave any indication that they considered the scope of the problem and how many solutions were possible. Each appears to have seized on some particular date and time of alignment solely because it seemed, a priori, the logical solution to the problem they were addressing. A sounder approach, we argue, is empirical: making all possible observations first and only later deciding which, if any, were significant.

This raises the issue of when one might expect that the point of an environmental effect is its rareness and when its high frequency. Here the built environment can be suggestive. If the space is small and delimited by a wall, then the number of possible celestial observations is reduced as compared to a large, open space with its ample

\footnotetext{
${ }^{26}$ Cf. Scholander 1952: 372: "Betweenness. We now consider a set $S$ of elements a, b, c, in which, for each ordered set of three elements a, b, and c, there holds or fails to hold a relation denoted by abc and read "b is between a and c."

${ }^{27}$ See Schütz 2011: 85. Note that the critique in Frischer and Fillwalk 2014: 85-85 should be modified to say that Schütz ought to have specified whether his April 21 alignment was based on the sun's first gleam while bisecting the horizon line, or the moment when the solar disk is tangent to the horizon. On these two possibilities, see Hawkins 1966: 5. We assumed (perhaps unfairly) he meant the latter. On the former possibility see Tiede 2016, who at p. 270 reports that the sun bisects the horizon on axis with the Ara Pacis on both April 21 and August 27. Using our Model 1 we confirmed this observation.
} 
sightlines and viewsheds. So, in the case of a small built environment closed off from its surroundings by walls, we would expect—all things being equal—that the rare variant of the frequency rule is operative. ${ }^{28}$ Of course, there are exceptions. If, for example, there are observational markers in a large area, then, clearly, the ancient viewer was interested primarily in those environmental effects perceptible from the markers. The best evidence of a marker is physical: we expect a built feature with the right orientation and with an alignment occurring on a date with cultural significance. In prehistoric cultures, this was typically a solar event such as a solstice or an equinox. In historical cultures, the range of culturally significant dates known to us, typically through literary remains, is much broader. If there are no physical remains of such a marker, then, at least in the case of a literate culture, there may be written or inscriptional evidence that survives, referencing the fact that there once was a marker. Hence, in the case of a large, open space, it is possible in principle that the rare variant of the rule could be applied. On the other hand, absent special markers (or at least textual attestation of lost markers), it is not unreasonable to find that a large space exemplifies the high-frequency variant of the rule. Of course, it is possible to imagine a tertium quid in which there are both solar markers used on specific dates and also other-and more frequent-alignments seen in a variety of spots in a large, open area. In fact, we will see that this final possibility offers a plausible explanation for our findings about the Augustan solar program in the northern Campus Martius and Campus Agrippae.

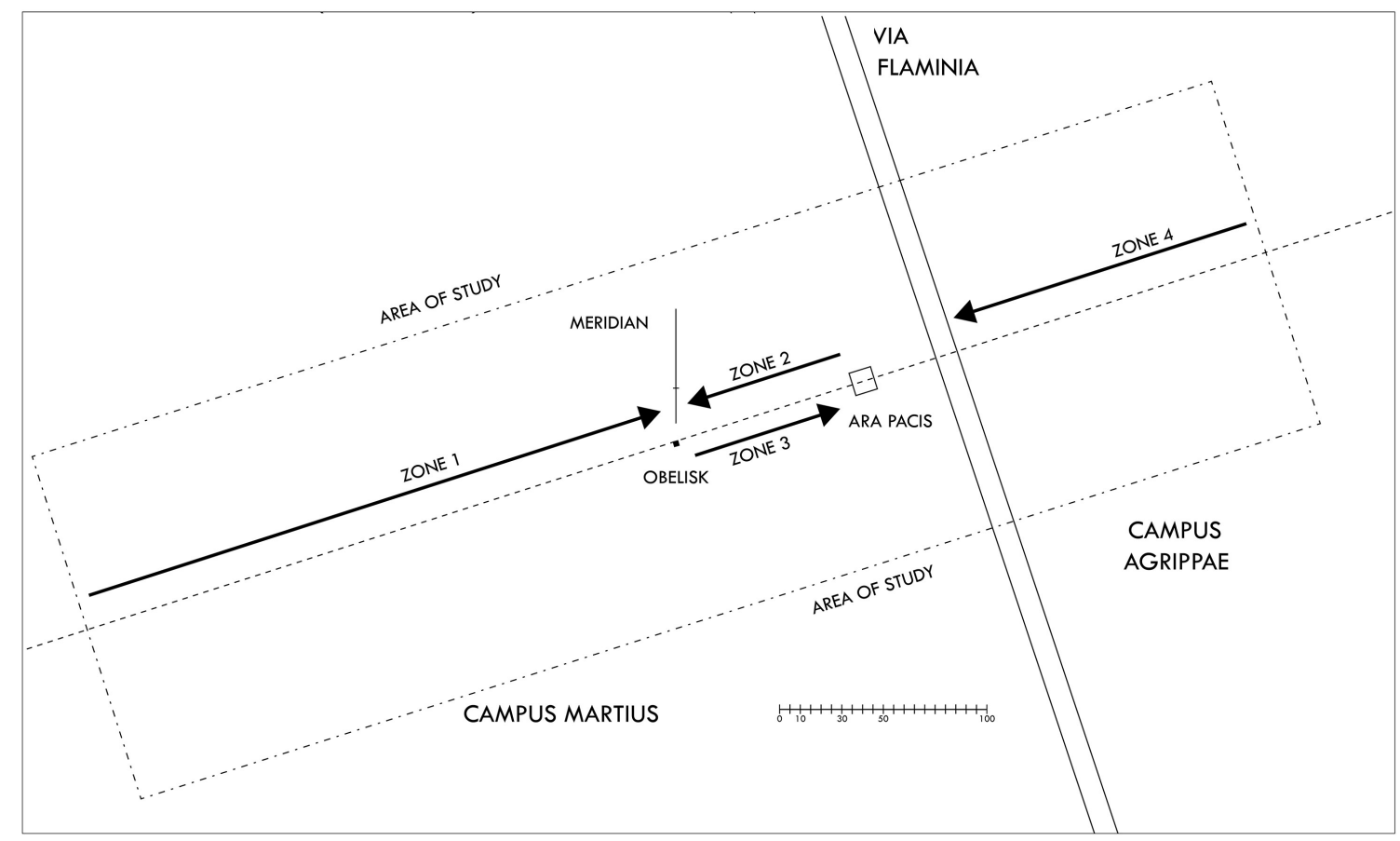

Figure 4. Map showing area where solar and shadow alignments were investigated. Source: Matthew R. Brennan, Virtual World Heritage Laboratory, Indiana University.

\footnotetext{
${ }^{28}$ For an example, see Frischer and Fillwalk 2012 on the alignment occurring on the summer solstice in the lower sanctuary of Roccabruna at Hadrian's Villa.
} 
The area in which the Ara Pacis and obelisk were sited was quite large. We cannot specify the exact dimensions, but we can say that there is no evidence of Augustan urban development in at least a $600 \mathrm{~m}$ (NE-SW) x $150 \mathrm{~m}$ (NW-SE) rectangle around these monuments (figure 4), which could, indeed, have extended much farther, especially in the east-west direction. As part of the public parks of the Campus Martius and Campus Agrippae, this area was not enclosed by walls. No Augustan solar markers have been found, nor are any mentioned in the surviving ancient texts. Hence, in principle, we would not expect the single alignment theory such as that proposed by Buchner to be valid. Rather, we would expect there to be so many alignments that focusing on just one can only be termed arbitrary and a case of selective observation.

At any rate, we have limited our study to just this area of ca. $600 \mathrm{~m} \mathrm{x} 150 \mathrm{~m}$ because it was, as far as we know, free of buildings that could have interfered with the intervisibility of the monuments of interest to us. In particular within this zone we investigated the area $295 \mathrm{~m}$ west of the obelisk and $190 \mathrm{~m}$ east of the Ara Pacis (=290 $\mathrm{m}$ east of the obelisk) all along the extension of the axis of symmetry of the Ara Pacis.

\subsection{The solar alignments}

There are two purely intervisible zones (figure 4) where alignments were observed such that, from the point of view of someone stationed on the axis formed by connecting the mid-points of the Ara Pacis and the obelisk, the mid-point of the obelisk's finial overlapped the middle of the solar disk: Zone 1 west of the obelisk (Appendix table 1; figure 5) and Zone 4 to the east of the Ara Pacis (Appendix table 4; Model 1). The areas studied could be extended farther in both directions. Assuming there were no buildings obstructing the way, ${ }^{29}$ the Tiber, ca. $1.2 \mathrm{~km}$ from the obelisk, would have provided the natural limit for Zone 1 to the west.

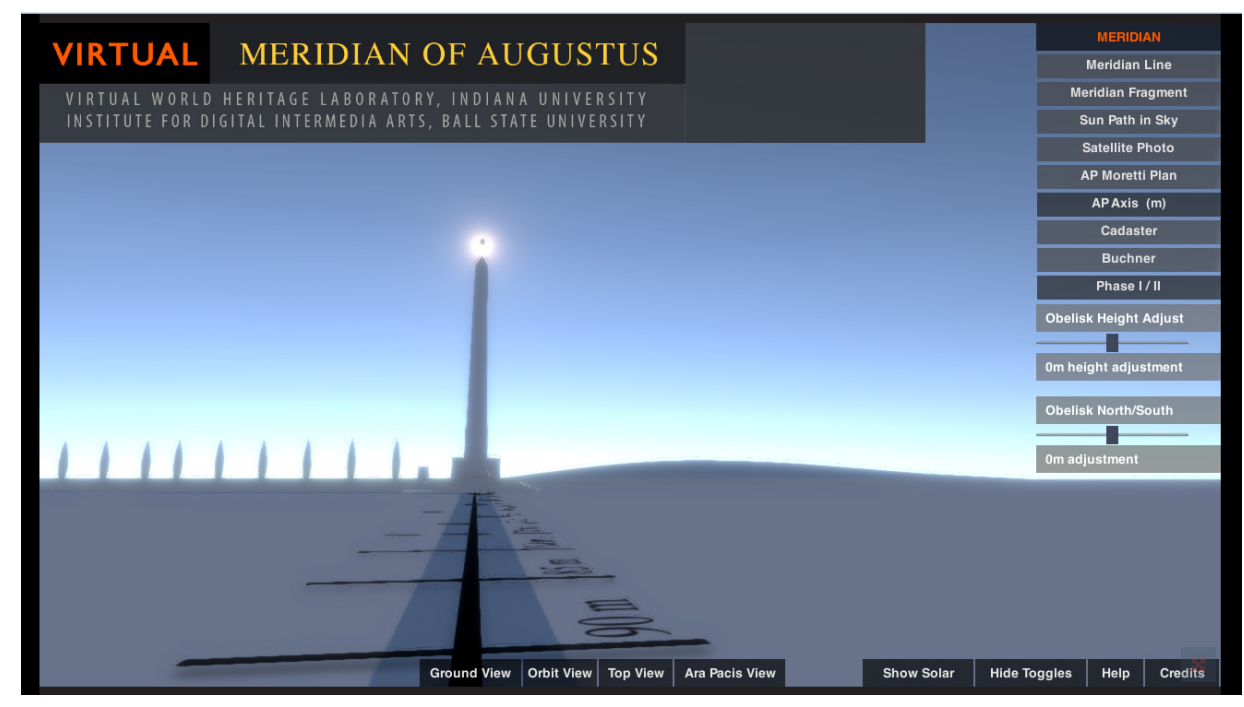

Figure 5. Zone 1: the sun is centered over the obelisk as observed by someone standing ca. $100 \mathrm{~m}$ west of the obelisk. The Ara Pacis is seen in the background. Source: Institute for Intermedia Arts, Ball State University, in collaboration with the Virtual World Heritage Laboratory, Indiana University.

\footnotetext{
${ }^{29}$ Dumser 2002 has no other Augustan features in this area. See also the related Digital Augustan Rome: http://digitalaugustanrome.org/
} 
Similarly, the area studied in Zone 4 to the east of the Ara Pacis across the Via Flaminia is not known to have offered obstructions and formed part of the public park known as the Campus Agrippae, the exact bounds of which are not known but which certainly reached even farther north than the Ara Pacis. ${ }^{30}$

The first known potential obstruction of the axial sightline was the raised section of the Aqua Virgo ca. $475 \mathrm{~m}$ east of the Ara Pacis. ${ }^{31}$ This falls well outside the area we studied. Another potential obstacle (the Tiberian Ara Providentiae) will be discussed below (section 11).

Zone 3, the ca. 90 meters from the base of the obelisk to the west entrance of the Ara Pacis, is purely interpositional (figure 6). When one stood somewhere between the obelisk to one's back and the west façade of the Ara Pacis, it afforded views of the rising sun east on axis behind the Ara Pacis (Appendix table 3).

Finally, one area is both interpositional and intervisible: Zone 2, in the 100-m area between the west entrance of the Ara Pacis and the obelisk (Appendix table 2; figure 7). The interpositional part of this zone falls inside the western precinct of the Ara Pacis from which, on several dates, one can see the sun over the obelisk to the west; on most dates, however, one must stand somewhere west of the Ara Pacis to see this effect. On these dates, the zone is characterized by interpositionality.

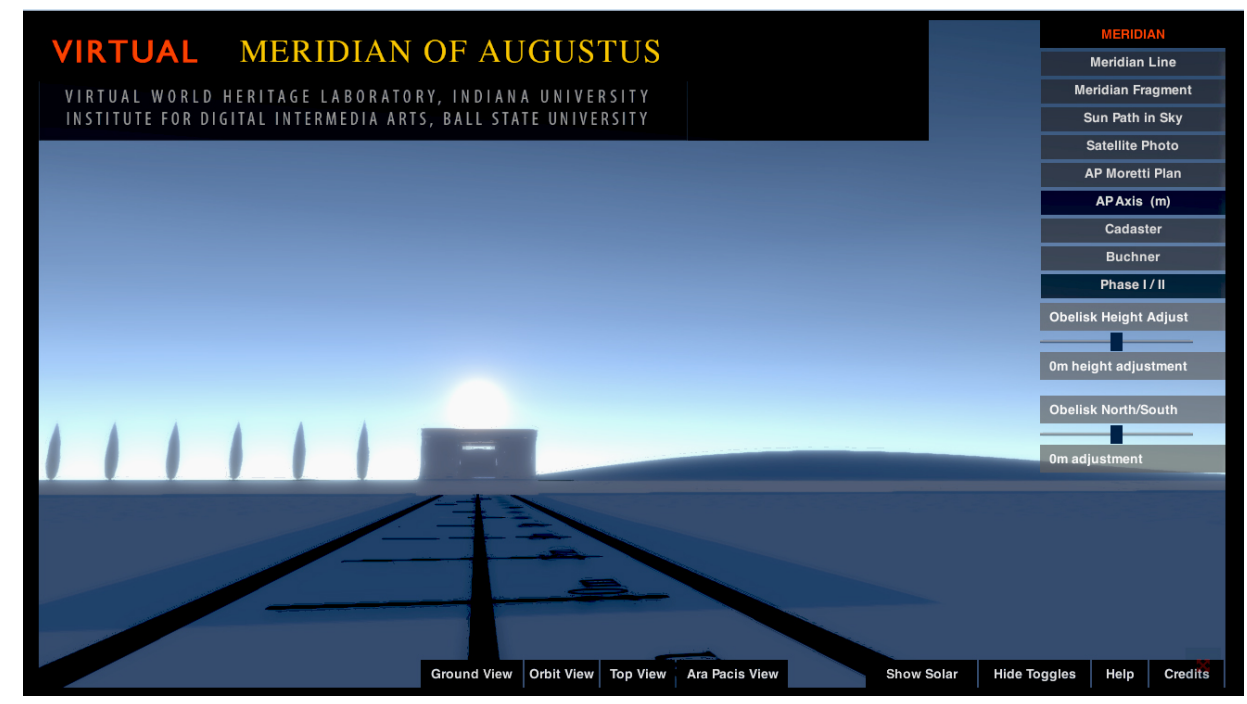

Figure 6. Sunrise seen in Zone 3. Source: Institute for Intermedia Arts, Ball State University, in collaboration with the Virtual World Heritage Laboratory, Indiana University.

\footnotetext{
${ }^{30}$ As indicated on the Digital Augustan Rome map; http://digitalaugustanrome.org/. That the area across the Via Flaminia from the Ara Pacis belonged to the Campus Agrippae is suggested by the fact that the Temple of the Sun in campo Agrippae was built in this general area under Aurelian; see Liverani 2006-2007. Before Aurelian's temple—of obvious significance for our theme in this study (see Salzman's contribution below in section 12) — there is no definite evidence that this section of the Campus Agrippae was occupied by any buildings (on the possibility that the Ara Providentiae stood in the area, see below, section 11).

${ }^{31}$ Frontinus 1.22 tells us that "the arches of the Virgo begin below the Horti Lucullani," i.e., in an area in or near the northeast part of the Campus Agrippae. Thus the arches will have intersected our axial line. For the location, see the map in Dumser 2002.
} 
The four zones provided optimal viewsheds for seeing the axial alignments: Zones 1, 2 (except for the interior of the Ara Pacis) and 3 are flat; at its eastern extreme Zone 4 encountered a rise up the southern extension of the Pincian, which, however, only increased the visibility of the obelisk. As far as we know, there were no obstructions to the sightlines in the Augustan age all the way in Zone 1 to the Tiber, $1.2 \mathrm{~km}$ from the obelisk, although the validity of this claim is not important for our argument, which, as noted, is limited to the area $295 \mathrm{~m}$ west of the obelisk: it provides alignments enough to prove our point. To the east, in the Augustan period, there are no securely known obstructions in Zone 4 for the ca. $585 \mathrm{~m}$ east of the obelisk until, as already noted, the superstructure of the Aqua Virgo was reached. ${ }^{32}$ Viewshed analysis shows that, absent obstructions, an obelisk with a height of $29.6 \mathrm{~m}$ could potentially ${ }^{33}$ be seen as far as $19 \mathrm{~km}$ in all directions, so its visibility in the limited area we studied is beyond question. The Ara Pacis, whose exact height is not known since the superstructure does not survive but which can be estimated to have stood 4.5 to $5.0 \mathrm{~m}$ high, was potentially visible for 7.6 to $8.0 \mathrm{~km} .{ }^{34}$ Hence, it, too, was certainly visible within the area we studied.

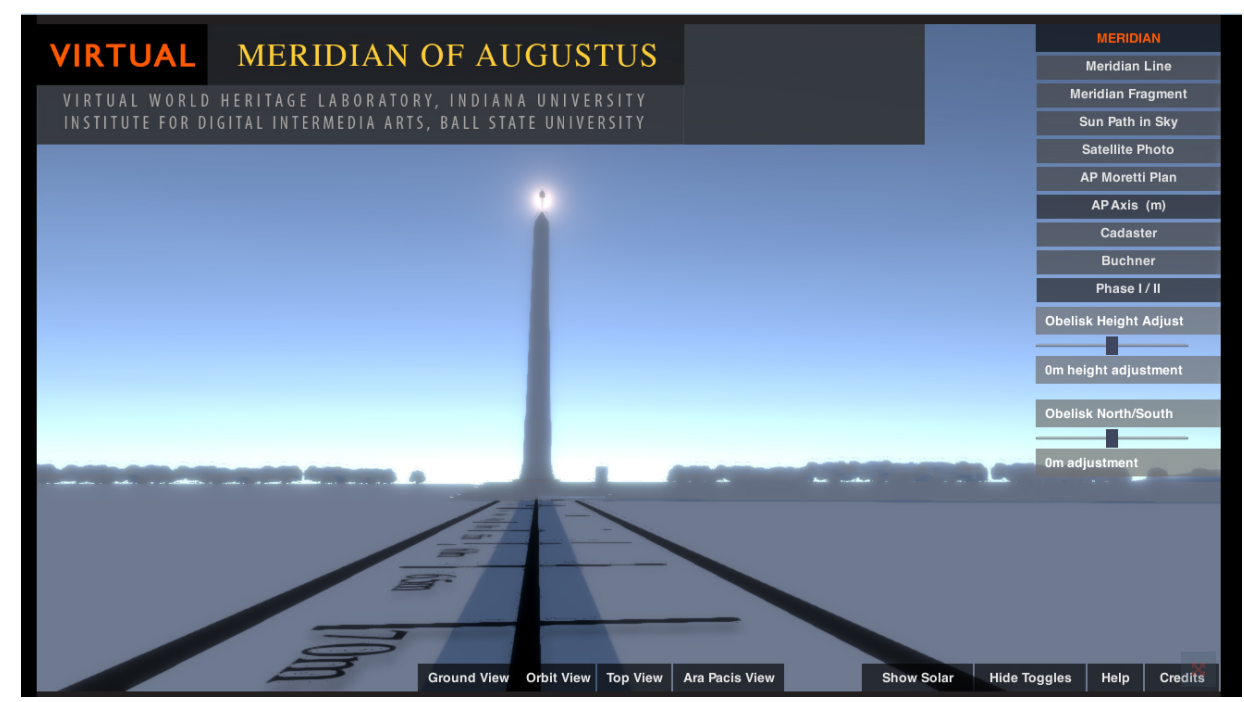

Figure 7. Zone 2. Source: Institute for Intermedia Arts, Ball State University, in collaboration with the Virtual World Heritage Laboratory, Indiana University.

We may conclude that, barring other unknown obstructions, the two monuments were readily visible along their axial line in the area we studied.

\footnotetext{
${ }^{32}$ That the Ara Providentiae stood on the axial line of the Ara Pacis about $30 \mathrm{~m}$ east of the Via Flaminia is merely speculation and, if true, does not contradict the interpretation we offer here. See below, section 11.

33 "Potentially" means that atmospheric refraction was at a minimum.

${ }^{34}$ The formula for calculating the visibility of an object on a flat landscape is the square root of $13 h$, where $h$ is the height of the object [see Magli 2017: 7]. Assuming good atmospheric conditions and barring any physical obstructions, Neil Devadasan, lead systems engineer and technology manager of the Polis Center of Indiana University-Purdue University Indianapolis, calculates that the visibility of the obelisk could have extended for $19.43 \mathrm{~km}$. Applying the same formula to the Ara Pacis, the results are $7.576 \mathrm{~km}$ for a façade that was $4.5 \mathrm{~m}$ high and $7.986 \mathrm{~km}$ for a façade that was $5.0 \mathrm{~m}$ high. Buchner 1976: 33, figure 11 reports the surviving portion of the Ara Pacis' west facade to be $4.01 \mathrm{~m}$. Bernard Frischer thanks Dr. Devadasan and Prof. David Bodenhamer, executive director of the Polis Center, for their help in making this determination.
} 
In Zone 1 (Appendix table 1), we found forty-seven pairs of dates with intervisible alignments of the sun's disk seen over the obelisk, to which can be added the summer solstice, giving us 95 individual alignments in all. The dates in the area studied range from May 8 to August 10 and occur in the early morning not long after sunrise. If the zone is extended all the way to the river, then the range of dates is increased by about two weeks into midApril and another two weeks to late August. ${ }^{35}$

The Ara Pacis is located ca. $90 \mathrm{~m}$ from the obelisk. In Zone 2, running westward from the west entrance of the altar to the obelisk, there are 189 alignments of the sun over the obelisk seen from the altar to a point ca. 23.5 $\mathrm{m}$ from the obelisk, when the summer solstice is reached; after the solstice, one slowly retraces one's steps back toward the altar to see the alignments. In addition to the summer solstice, there are the two groups of dates running from March 19 to June 23 and from June 25 to September 27 (see Appendix table 2). The solar alignments occur in the mid- to late afternoon. The first two pairs of alignments occur inside the western part of the Ara Pacis and hence entail intervisibility. For the other pairs, only the obelisk is visible in front of the observer while the Ara Pacis is to his back. So these alignments exemplify interpositionality.

In Zone 3, exemplifying interpositionality, we found 111 dates on which a person standing on the axial line with the obelisk to his back and facing the Ara Pacis would have seen the sun rise on axis with the Ara Pacis (Appendix table 3).

Zone 4 is characterized by intervisibility, and in the area studied alignments of the sun seen over the obelisk were found in the mid to late afternoon for the period from February 28 to March 13 and from October 3 to October 17 (Appendix table 4). The first pair of alignments is visible at ca. 14 meters east of the east entrance of the Ara Pacis. While standing any closer to the altar, the observer's view of the obelisk is blocked by the east façade of the Ara Pacis. Since, as far as we know, there was no building occupying the land immediately to the east of the Via Flaminia in this area, ${ }^{36}$ the ancient observer might have continued several hundred meters farther east into the Campus Agrippae, finding ever new alignments into mid February and late October. We explored in detail as far as $190 \mathrm{~m}$ from the Ara Pacis (=ca. $290 \mathrm{~m}$ east of the obelisk).

To summarize, the dates when solar alignments were found range from February 28 to October 17. Had we continued our study beyond $290 \mathrm{~m}$ to the east of the obelisk and $295 \mathrm{~m}$ to its west, we could have extended the range of dates from at least mid-February to late October. But limiting ourselves only to the alignments we recorded, there were solar alignments on a minimum of 224 days of the year along the line connecting the middle of the Ara Pacis and the Montecitorio Obelisk, as documented on Appendix tables 1-4 and summarized on Appendix table 6.

A second environmental effect of equal interest to us is the shadow cast by the obelisk into the interior of the Ara Pacis. This effect is clearly also solar in the sense that only sunlight striking the obelisk could cause it to cast its shadow across the Campus Martius. As noted above, Buchner's theory held that the shadow reached the mid-point of the altar on September 23, Augustus' birthday, so he was already thinking in terms of this effect. Our simulations show that Buchner's hypothesized shadow did not travel, as he imagined, into the west entrance

\footnotetext{
${ }^{35}$ Noreña 2013 speculated that the Ustrinum of Augustus stood at the intersection of our axial line with the line from the mid-point of the Pantheon and Mausoleum. According to our measurements, the two lines do not, in fact, intersect at this point but ca. 8 meters north of the midpoint of the Pantheon-Mausoleum line.

${ }^{36}$ For the so-called Arco di Portogallo and the Ara Providentiae, see below section 11.
} 
of the altar on that date, so his theory is not valid [Frischer forthcoming, section 12]. But we found that what Buchner imagined might happen on one date actually did occur at many other times, viz., on twenty-four pairs of dates (Appendix table 5). These occur in the late afternoon and cover the periods from February 25 to March 21 and from September 27 to October 21.

To conclude this section, adding the dates of shadow alignments to those of solar allows us to report with certainty that there was at least one solar or solar-shadow event in this part of Rome every day during 239 days in the period from February 25 to October 21 . Some dates had more than one alignment event. For an overview of all the alignments throughout the year, see Appendix table 6 .

Finally, we note that in this section we are simply reporting the facts as observed using the new virtual simulation; we are not yet interpreting the phenomena. We should, however, clarify here that, in our interpretation to follow, we will claim no specific significance for the individual dates in the period running from February 25 to October 21. Our point is that significance arises from the dates in the aggregate. Taking this approach to its logical conclusion, one might ask why we do not find solar alignments every day of the year. The reason is clear: the Ara Pacis was oriented to the pre-existing Via Flaminia, which is rotated $18^{\circ} 37^{\prime}$ west of north. To obtain solar alignments every day of the year, the axial line joining the Ara Pacis and obelisk would have to have been aimed at sunset on the winter solstice, i.e., rotated $23^{\circ} 30^{\prime}$ west of north. The need for the Ara Pacis to respect the orientation of the pre-existing Via Flaminia was apparently a given of the design program.

Of course, the altar could have been erected elsewhere, and/or it could have been given a different orientation. So it is intriguing to speculate that, in addition to purely aesthetic considerations of creating a parallelism between the eastern façade and the nearby thoroughfare, the Augustan planner was motivated to give the Ara Pacis this particular orientation in order to facilitate an alignment of the altar with the first gleam of the sun on the Parilia, April 21 [Tiede 2016, confirmed by our Model 1 on April 21, 9 BC, at 4:15 UTC]. Following this line of reasoning, the project to construct the Ara Pacis off the Via Flaminia (securely datable on the basis of ancient sources to $13 \mathrm{BC}$ ) will have preceded that to site the obelisk ca. 90 meters down the line of symmetry of the Ara Pacis. The obelisk, dedicated in 10/9 BC on the basis of still extant dedicatory inscription (see $\mathrm{n}$. 56), will have been added as a compatible, secondary elaboration of the original plan. It related the Ara Pacis to the sun, as before, but now on a great many days of the year, no longer on a single festival day, and it also tethered the altar to a monument symbolic of the sun to its west, instead of simply to a single sunrise on the horizon to the east.

\subsection{Stress tests of the alignments}

It is important to discuss two possible factors that could potentially affect the results thus far reported: the cycle of four years from one leap year to the next; and the matter of the height of the obelisk.

To begin with the first factor, we have noted that Appendix tables $1 \mathrm{~A}-4 \mathrm{~A}$ report on observations for the year 9 BC. Appendix tables $1 \mathrm{~B}-4 \mathrm{~B}$ take a random sample of two dates from $1 \mathrm{~A}-4 \mathrm{~A}$ and report the observations for them during the following two years of the four-year cycle from one leap year to the next (in the fourth year, the sun returns to its position in the first year, so it is not included). As will be seen, none of the alignments is invalidated, though the exact position where one must stand as well as the time of day changes slightly (in some cases by as much as 24 hours). 
As noted above, there is a scholarly debate about the height of the obelisk with sphere. Under consideration are heights of $29.6 \mathrm{~m}$ [Albèri Auber 2014: 72] and $30.7 \mathrm{~m}$ [Schütz 2011: 78-79]. The higher value requires that we move the obelisk $0.90 \mathrm{~m}$ farther south with reference to the lower. So the current range of values under consideration is ca. $1.00 \mathrm{~m}$ in height and $0.90 \mathrm{~m}$ in latitude. Our Unity and Stellarium simulations make it possible to raise or lower the obelisk $\pm 2 \mathrm{~m} .{ }^{37}$ We can also move the obelisk along the southern extension of the meridian by the same amount. Using these two simulations, we performed "stress tests" to see if the solar alignments reported above could survive if we change the height used in the simulation from $29.6 \mathrm{~m}$ to $30.7 \mathrm{~m}$ with a related shift southward by $0.90 \mathrm{~m}$ of the obelisk. The results are presented on Appendix tables 1C-4C. Because of the sun's apparent angular motion through the sky, we found that generally these changes did not invalidate any of the alignments reported here: all one needs to do is slightly adjust one's position and/or the time of day to compensate for the obelisk's altered position (figure 8). There were exceptions: the shadow alignments of March 20 and 21 seen with the $29.6 \mathrm{~m}$ obelisk do not occur with the $30.7 \mathrm{~m}$ obelisk. In compensation, though, with the taller obelisk we observed fifteen alignments that did not occur with the shorter obelisk (see Appendix table 4D). So the taller obelisk-far from invalidating our results—would give us a net gain of thirteen new shadow alignments.

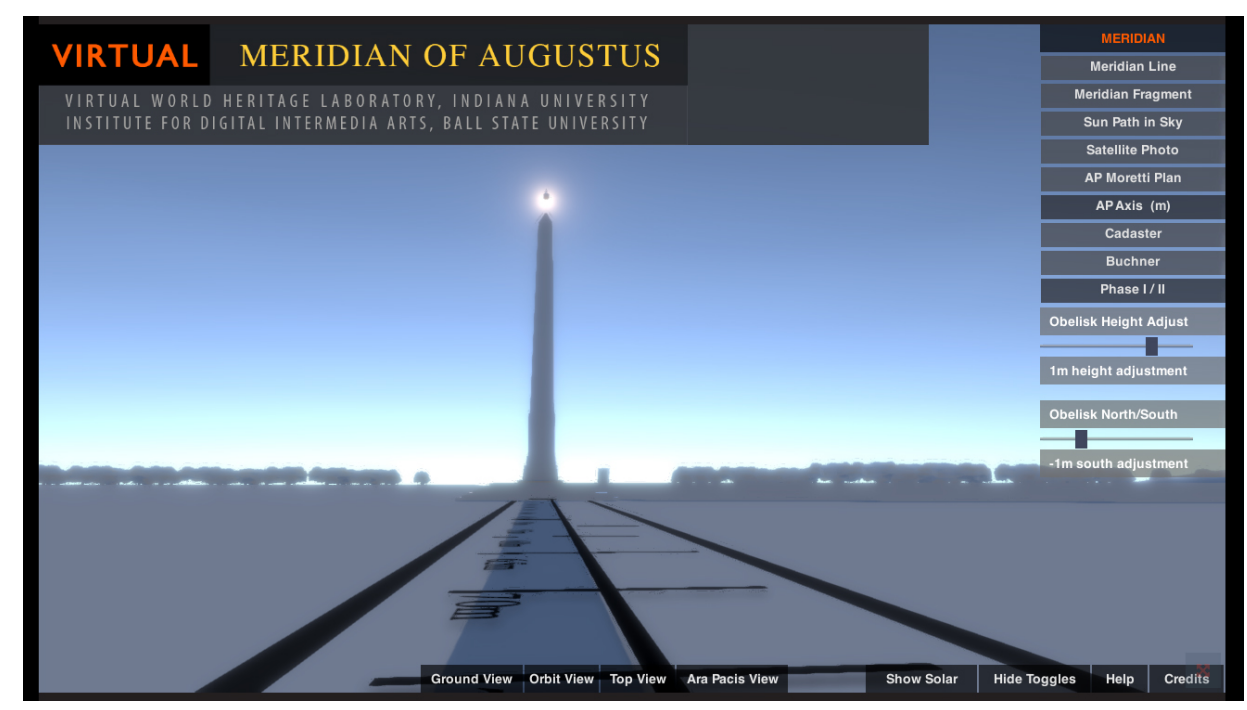

Figure 8. Stress test in Zone 2 at same date and time seen in figure 7, with obelisk raised to $30.7 \mathrm{~m}$ and moved south by $1 \mathrm{~m}$. Source: Institute for Intermedia Arts, Ball State University, in collaboration with the Virtual World Heritage Laboratory, Indiana University.

To summarize, the northern Campus Martius and adjacent Campus Agrippae were the stage for a recurrent light and shadow show of alignments between the sun, obelisk, and Ara Pacis. At a minimum, alignments of sun or shadow took place 239 days each year in the period from February 25 to October 21 (Appendix table 6). The details of exact time and place change slightly in the second and third years of the leap-year cycle. Even if the height of the obelisk is increased to $30.7 \mathrm{~m}$, and the position of the obelisk is adjusted accordingly, essentially the same series of alignments is attested, and, indeed, the number of dates increases to 254 in the

\footnotetext{
${ }^{37}$ Even though a flexibility of height and position of $\pm 1 \mathrm{~m}$ would have sufficed in the light of the current state of scholarship, we designed the simulation to support changes of $\pm 2 \mathrm{~m}$ in case future discoveries require greater adjustments.
} 
period from February 17 to October 28. It is for this reason that we stated earlier that the debate about the exact nature and design of the Augustan timepiece is not pertinent to our study of the relationship of the Ara Pacis and Montecitorio Obelisk.

We turn next to our interpretation of this new information revealed by the computer simulations about the Augustan solar program in the northern Campus Martius and Campus Agrippae. We will show that the solar program is appropriate in view of the dedication of the Montecitorio Obelisk to Sol, Augustus' role as king of Egypt, and Augustan propaganda which closely linked Augustus to Apollo, a god with a strong solar aspect. We will also show that later emperors protected the Augustan solar program and in at least two cases may even have enhanced it with new features. Finally, in the Conclusion (section 13.2), we consider the issue of whether the recurrent annual light and shadow spectacle was likely to be intentional or accidental. We begin with the Egyptian background and in this connection flag the highly pertinent remarks in Herklotz 2007: 209-229 about Augustus' relationship to the Sun god.

\section{EGYPTOLOGICAL REFLECTIONS ON THE ARA PACIS}

\section{Giuseppina Capriotti Vittozzi}

The position of the Ara Pacis and its newly discovered relationship with the Montecitorio obelisk of Augustus suggest an Egyptological approach to the monument. ${ }^{38}$ Such an approach will look to the presence of Egypt in Rome in forms that are sometimes explicit, sometimes mediated, and are expressions of that Mediterranean koiné to which Egypt offered a notable contribution.

The obelisk is definitely a product of Egypt, while the Ara Pacis at first glance incorporates classical forms. Researchers of the altar it have properly sought possible models in the Greek and Italic context while recognizing unique elements of its design [Trimble 2007]. Trimble noted that on account of the great variety of potential models, none exactly replicated in the Ara Pacis, "in the current view the Ara Pacis is understood to embody a multi-layered appropriation of the past, recombined in sophisticated and innovative ways to meet the needs of the present" [Trimble 2007: 11]. The hypothesis that is presented here springs from the observation of the monument not from a stylistic or iconographic point of view but from that of its function in relation to a topography that included the obelisk. This study has been made possible thanks to the simulations conducted by Bernard Frischer, who has brought to light special visual relationships at specific times of the year between the sun, the obelisk, and the Ara Pacis. Thus we present here an hypothesis which looks at the possible function as the construction of a sacred landscape inspired by analogous sacred areas of a different tradition.

The appropriation of foreign motifs [see Trimble 2007] and, in particular, those from pharaonic Egypt, had various intensities and nuances at Rome, characterized by the Romans' ability to adapt, translate and attribute new meanings to foreign cultural traditions [Capriotti Vittozzi 2013]. In the Ara Pacis one may thus imagine an ambiguity of architectonic language which can at once express a creative bond with traditions like those of Greece and Italy while at the same time charging them with new meaning by alluding to different and important traditions that entered at a later date into the cultural sphere of Rome.

\footnotetext{
${ }^{38}$ See Capriotti Vittozzi 2013 and for Egyptianizing decorative elements of the Ara Pacis, see P. J. E. Davies 2011: 360.
} 
Augustus' decision to bring to Rome the obelisk of Psametik II to serve as the support for the gnomon of a monumental meridian in the Campus Martius may be read in the light of what Ammianus Marcellinus (17.4.12-15) recounts about the desire of the princeps to transport to Rome the "unique obelisk" of Karnak, a monolith and the object of cult. Augustus abandoned this project, and the obelisk reached Rome much later and today stands before St. John Lateran (hence its alternative name, the "Lateran obelisk"). ${ }^{39}$ The obelisk, originally located in the eastern area of the great temple complex of Karnak [Barguet 1950], dedicated to the solar cult, was associated with the solar god and, by projecting its shadow onto the earth, it rendered the god present and indicated his passage through the sky [Bell 2002: 23; Capriotti Vittozzi 2013: 160]. The construction of Augustus' solar park, as Frischer calls it above, must have represented a variation on ancient themes and new functions, yet it still referred to Egyptian models, albeit reinterpreted.

\subsection{The Ara Pacis and the "horned altar"}

The peculiar external architectural design of the Ara Pacis as a cubic structure crowned on the corners by acroteria $^{40}$ (figure 9) evokes, at least to an Egyptologist, the monumentalized form of the so-called "altar with horns." Its origin is debated, ${ }^{41}$ but in the Hellenistic period it imposed itself, in particular in explicit association with Greco-Roman cults.

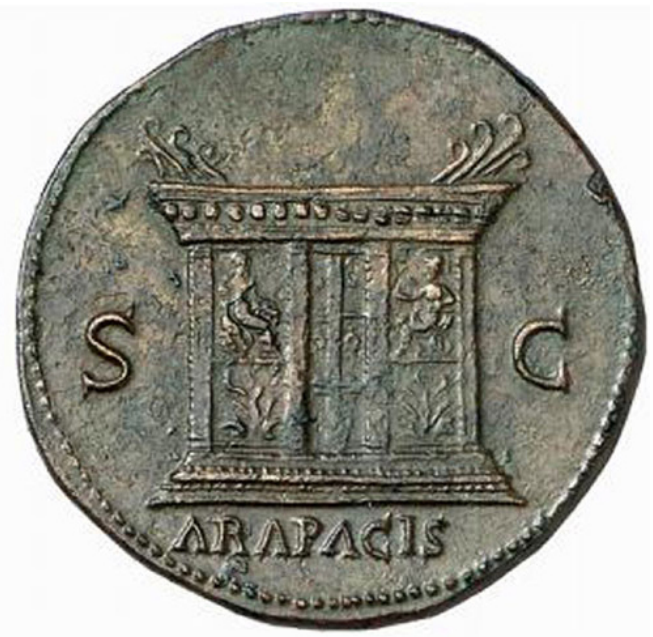

Figure 9. Bronze as coined at Lugdunum, ca. 64-67 AD, reverse illustrating the Ara Pacis. Note the volutes atop the façade. Source: courtesy of Helios Numismatik.

The oldest horned altar known in Egypt is found near the temple-tomb of Petosiris near Hermopolis Magna (figure 10), a strongly international site dated between the end of the fourth and beginning of the third century BC. During the Hellenistic period, the type spread both as an architectural structure used in temples and also

\footnotetext{
${ }^{39}$ Capriotti Vittozzi 2013: 158-160, with earlier bibliography.

${ }^{40}$ The acroteria are seen on coins of Nero and Domitian. The excavator noted that "one unrecoverable loss must be lamented: that of the crown with the obligatory frieze and probable acroteria." See Moretti 1938: 490 (translation by B. Frischer). For the coins, see Calandra di Roccolino 2007.

${ }^{41}$ It is attested from very ancient times in the Middle East and has been placed into a Minoan context; see, for example, Quaegebeur 1970: 195; Hitchcock 2002.
} 
as portable furniture, including in funerary contexts [Soukassian 1983]. The type is found again in Isiac contexts, for example in the temple of the Egyptian divinities on Delos [Deonna 1938: 387; Soukassian 1983: 331-332]. The case of Delos appears particularly instructive for the relationship which has been suggested between this kind of cult structure and the so-called horned altar of Phoebus [Deonna 1938: 436; Quaegebeur 1970: 195], cited in Callimachus' second hymn to Apollo [Bruneau 1995]. On Faience oionochoai (figure 11), the Ptolemaic queens depicted with cornucopias execute a rite before this kind of altar [Burr Thompson 1973].

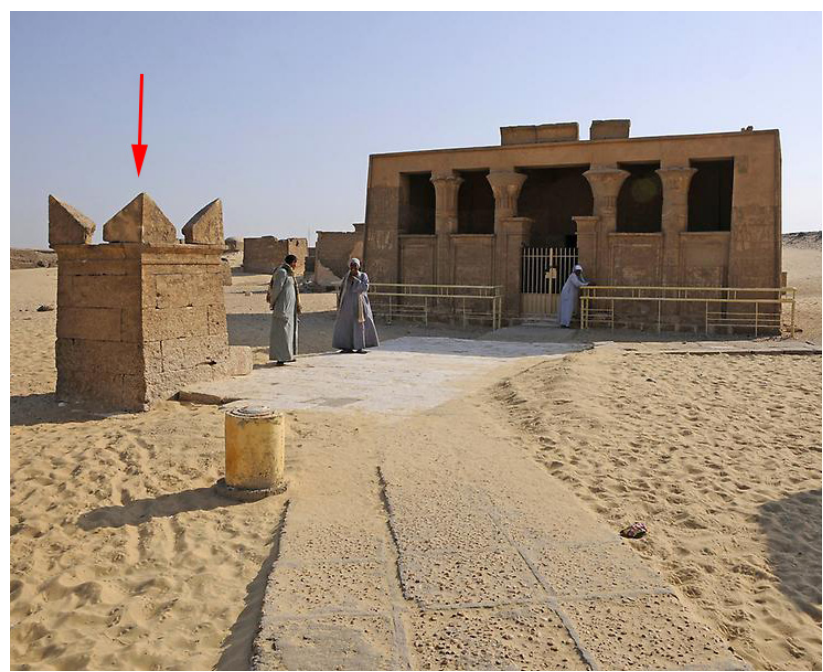

Figure 10. Horned altar (red arrow), in front of the temple-tomb of Petosiris near Hermopolis Magna. Source: courtesy of Gerhard Huber, copyright 2009.

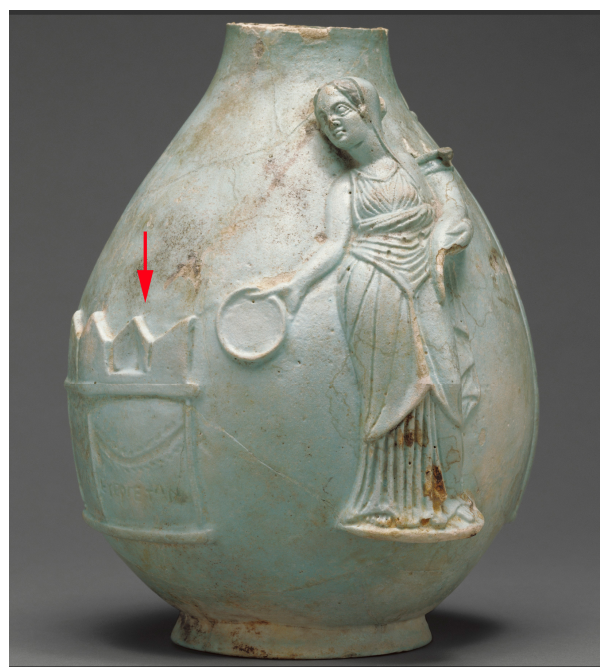

Figure 11. Faience oinochoe, ca. 243-221 BC, showing Berenike II holding a cornucopia while standing before a horned altar (red arrow). J. Paul Getty Museum, inventory 96 AI 58. Source: used with kind permission of the J. Paul Getty Museum.

One may also imagine that the altar had a solar function: ${ }^{42}$ on it fire consumed the sacrifice. ${ }^{43}$ As Soukassian emphasizes, the holocaust could be offered to various divinities; however it was intended to destroy the enemies of both the solar god [Quaegebeur 1993] and the king himself, evoking the battle between the sun and his enemies which was renewed each morning near the eastern horizon. ${ }^{44}$ A great structure of this kind is present right in the eastern area of the temple of Karnak, ${ }^{45}$ and it has been related by Klotz to the "Unique Obelisk" and with the so-called "Contra Temple" decorated in the reign of Domitian [Klotz 2008]. According to Klotz, the situation of the horned altar in the area of the solar cult of Karnak has a precise meaning in relation to the topography of Karnak as "a projection of the solar cycle, and the Contra Temple represents the Eastern Horizon...the location of the... 'place of destruction,' where the enemies of Re are ultimately destroyed by the newborn and recharged solar disk in a fiery bloodbath, the cause of the red sky immediately before sunrise"

\footnotetext{
42 This did not seem obvious to Soukassian [1983: 320].

${ }^{43}$ According to Deonna 1938, just the perfumes; for another view see Quaegebeur 1970: 19-197; Soukassian 1983: 330-331;

Quaegebeur 1993. See, recently, Nachtergael 1998; Klotz 2008: 71, with earlier bibliography.

${ }^{44}$ On the various traditions and in particular the Heliopoitan, see Yoyotte 1978; Yoyotte 1981: 84-90.

${ }^{45}$ Chevrier 1949; http://dlib.etc.ucla.edu/projects/Karnak/resource/ContraTemple/428
} 
[Klotz 2008: 75]. In myth, the god is reborn every day on the eastern horizon after the bloodbath of battle, inaugurating a new era.

\subsection{The horned altar as the Eastern Horizon}

This function of the horned altar and its particular history in Greco-Roman Egypt leads to a further thought. Soukassian has emphasized that it is difficult to trace in the Egyptian tradition a comparable structure, and thus we might well be faced with an emprunt [Soukassian 1983: 328]: such a loan, however, was evidently acquired and reinterpreted in accordance with tradition, given its broad use in temple contexts thousands of years old. Quaegebeur [1970: 196 n. 4] has noted that the horned altar may have been at the root of a new kind of altar attested in the Ptolemaic period which is also seen in a hieroglyphic sign (figure 12): it is made up of a strut, already known from the Egyptian tradition, surmounted by a kind of table with raised sides, which resembles precisely the sign for the horizon (figure 13). ${ }^{46}$
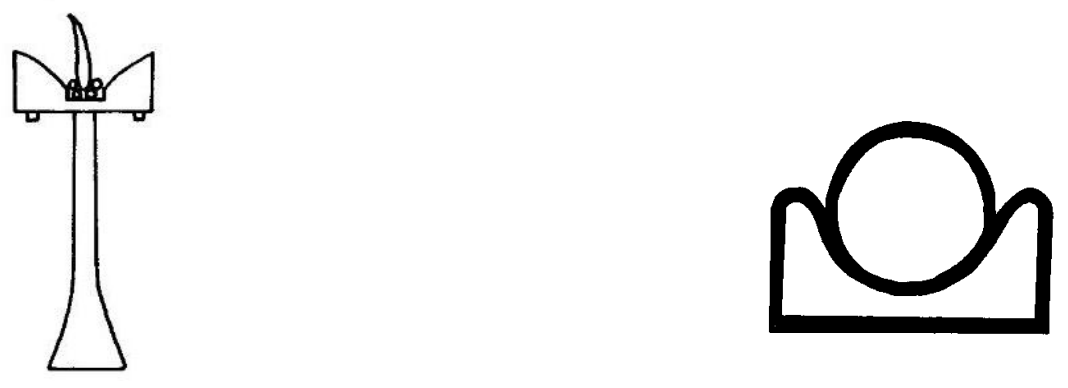

Figure 12. Horned altar as hieroglyph in Ptolemaic inscriptions; Figure 13. The Akhet hieroglyph. Cf. Frischer's zone 3 (figure 6). see Quaegebeur 1970:196n4.

In the Egyptian tradition, such a sign represents the two mountains framing the reborn sun, that is to say, the place, par excellence, of the divine epiphany. In Ptolemaic and Roman times it is attested in this sense as an indicator of the temple itself. ${ }^{47}$ The connection made by Klotz between the eastern horizon and the horned altar, as well as the dependence of the altars formed by the sign of the horizon on the pedestal emphasized by Quaegebeur, seem to reveal the Egyptian interpretatio of the horned altar as a model capable of making present the place of battle between the solar god and his enemies at the moment of his rebirth. The loan assumed from the Egyptian tradition becomes particularly suggestive when we consider an image preserved in the Book of the Dead, in which the tomb is represented as the solar horizon and thus as a place of rebirth [Chapter 192, figure 7]. Furthermore, research conducted by Lehner and others on the Giza Plateau underlines a very ancient tradition regarding the monumental construction of the akhet sign in order to focus the sunlight at the horizon. Indeed, the pyramids of Khufu and Kafra provide the frame for sunset on the summer solstice. ${ }^{48}$

\footnotetext{
${ }^{46}$ See also Soukassian 1983: 323, 325 figs. 12-13.

${ }^{47}$ Wörterbuch der ägyptische Sprache, vol. 1, 17-19.

${ }^{48}$ In this case the sunset is consistent with the funerary purpose of the area; see Lehner 1985; Dash 2011. That the effect waas intentional was argued by Shaltout et al. 2007, Magli 2009, Magli 2011.
} 
Augustus' interest in Karnak and, in particular, in the eastern area and the Unique Obelisk make particularly appropriate the vision of the Ara Pacis out of which the sun seems to rise on axis, as demonstrated above by Frischer for his zone 3 (figure 6, and see Appendix table 3 for the dates). Such a choice inevitably imposed a precise meaning, and it poses, yet again — but in a new way-the old problem of the princeps' employment of Egyptian experts [Capriotti Vittozzi 2013: 85-87].

\section{THE MONTECITORIO OBELISK AS SOLAR SYMBOL}

\section{Molly Swetnam-Burland}

Understood as a functional monument - that is, as the support of the meridian's gnomon - the Montecitorio Obelisk (figures 2,14) has long stood at the center of debate about meaning-making in advertising the power of the new regime. It reminded viewers of Augustus' co-option of the new province, and its transportation from Egypt and re-erection in Rome were technological marvels. Yet most scholarly discussion has focused on the movement of its shadow, forging ideological connections in the Campus Martius as it traversed the pavement. Roman understandings of the symbolism and history of Egyptian obelisks, as dedications to the sun and embodiments of its rays, also enhanced the relationship between the Montecitorio Obelisk and the other structures situated in close proximity. ${ }^{49}$

The Montecitorio Obelisk was already centuries old when it was brought to Rome in 10/9 BC, and had a long history and rich symbolism in its own right. It was commissioned by the second and third kings of the $26^{\text {th }}$ Dynasty, Necho II and his son Psametik II (r. 610-595 BC and r. 594-589 BC). It is the first extant obelisk from the Late Period, a time of intense construction in Egypt that witnessed a deliberate return to language and monumental forms of the past. It was most likely one of a pair, as were most Egyptian obelisks, erected in the city of Heliopolis [Swetnam-Burland 2010: 139 - 141]. Generally speaking, in Egyptian culture the form of the obelisk symbolized the sun's benefits to the lands of Egypt, and even distributed the sun's regenerative powers. The rose granite material of which most were fashioned was reflective when polished, and some obelisks were faced with gleaming precious metals [Iversen 1968; D’Onofrio 1967; Habachi and Van Siclen 1974; Curran et al. 2009]. The Egyptian inscription on the monument - though only partially preserved, for the obelisk was heavily repaired when moved to stand in front of the Palazzo Montecitorio - states that this obelisk honored the sun god Re-Harakhti, an incarnation of the sun god that celebrated his rise at dawn. ${ }^{50}$ The text of the Montecitiorio Obelisk affirms his role in granting the king life, happiness, and power; and it praises Psametik as the ruler of Heliopolis and recently reunited Upper and Lower Egypt. ${ }^{51}$

Certainly, in its original context, the obelisk celebrated the divine rights of the king and honored the Sun god. As a monument, it was also efficacious: it both embodied the sun's rays, and reflected its benefits upon the land

\footnotetext{
${ }^{49}$ What follows draws upon my previous work on this monument, Swetnam-Burland 2010 and Swetnam-Burland 2015. I have been particularly inspired by new approaches to obelisks that investigate their biographies, diachronic history, and meaning in Roman contexts. For new approaches, Collins 2000; Parker 2003, 2007; Safran 1993; Schneider 2004, 2005; Sorek 2010. I am grateful to Bernard Frischer for the invitation to contribute to this exciting project.

${ }^{50}$ On the place of Re-Harakhti in Egyptian religion, Assman 1983: 21-143; Leitz 2002, IV: 630-632, s.v. Re-Harachte, an the encyclopedia entry listing all known titles and monuments associated with Re-Harakhti.

${ }^{51}$ For transcription and translation into Italian, Ciampini 2004: 143-149.
} 
and people. Its removal for use in the Augustan Campus Martius, however, abrogated this context and altered site- and culture-specific interpretations of its significance. In considering what this Egyptian monument "meant" in its Augustan context, therefore, it is important to keep in mind that what Romans knew of Egyptian history, culture, and religion as well as the way they constituted that knowledge differ in many ways from our own understandings. ${ }^{52}$

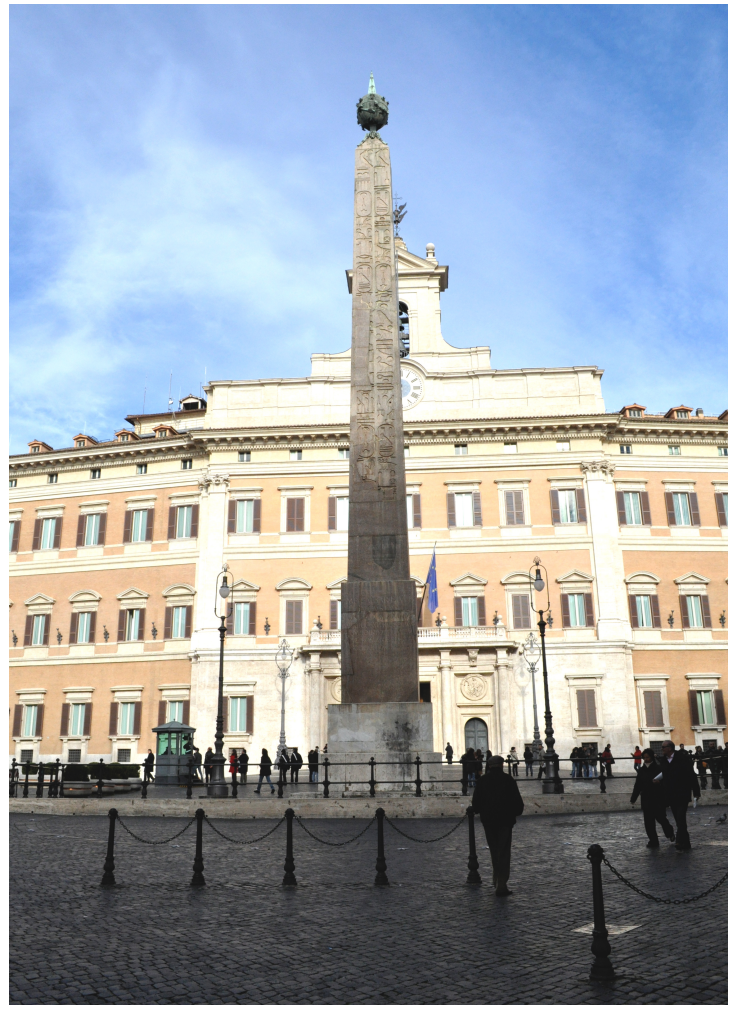

Figure 14. Montecitorio Obelisk, Rome. Source: photograph by Bernard Frischer.

Pliny the Elder, our best ancient source for the Montecitorio Obelisk and the manner of its display, refers to the king who commissioned it as Psemetnepserphreus. The name appears to derive from a transliteration of the name Psametik and the king's "good" name, Neferibre. This name suggests that Pliny's information did not come from the Greek historiographical tradition, and it is possible that his source for this unusual name may have been the obelisk itself [Swetnam-Burland 2010: 143]. A few monuments from the imperial period show that there were some people in Italy able to compose meaningful texts in hieroglyphic script, and thus presumably able to translate their texts. ${ }^{53}$ But this was a rare skill, associated chiefly with religious contexts. Hermapion's "translation" of the Piazza del Popolo obelisk is the only such document preserved by the literary

\footnotetext{
${ }^{52}$ Scholars often interpret the evidence for Egyptian influence on Roman culture in different ways, according to their training (that is, as Romanists or Egyptologists). For an Egyptological perspective this case, see Gregory 2012; Capriotti, above, section 3.

53 On Egyptians in Rome, see Noy 2004; Swetnam-Burland 2011; Swetnam-Burland 2015.
} 
tradition. The translation does not offer a word-for-word key to the text but rather interprets it, at once rendering the hieroglyphic script into Greek and making its content more understandable to readers of a different culture [Lambrecht 2001]. It is clear that Roman audiences did not interpret obelisks as would scholars today, or as would have Egyptians - either those of the past, when the obelisk was commissioned, or of the Roman-period. Even so, the "Egyptian" symbolism of the monuments was important to Italian audiences, and it appears that some members of the elite, like Pliny, had access to specialized, albeit partial, sources of information about their content.

How, then, might contemporary audiences have understood this symbolism? In addition to recording the name of the Egyptian king who commissioned the Montecitorio Obelisk, Pliny the Elder transmitted detailed information about its role as the gnomon in the meridian (also noting that, in his own lifetime, it had ceased to function accurately [Pliny HN 36.72-73]). For present purposes, however, his general description of obelisks takes precedence. Though Pliny offers many anecdotes about the commissioning and quarrying of these monuments, he attributes the same generalized function to all: "kings fashioned slabs of it [i.e., Aswan granite], in a certain kind of rivalry, calling them obelisks, sacred to the divine power of the sun. Their motif is in the representation of its rays, and is so signified by the Egyptian name... for truly, those carvings and representations which we see are Egyptian letters." ${ }^{44}$ Writing centuries later, Ammianus Marcellinus [17.4.6] similarly stressed that obelisks transmitted Egyptian wisdom, and that their shape emulated the rays of the sun. He also quoted a long section of a book about obelisks by Hermapion. Though the translation belongs to Augustus' other obelisk, set in the Circus Maximus and standing today in the Piazza del Popolo, this text also serves as confirmation of the solar properties of obelisks more generally, revealing an association between Apollo and Helios, the sun. The text repeatedly invokes Apollo as the child of the sun and, in places, conflates him with the earthly king, Ramestes; it casts Apollo as the recipient of the sun's benefits, and the intermediary who transmits this power to the world, by conquest and various acts of dedication and benefaction [Ammianus Marcellinus 17.4.17-23]. For Romans, then, obelisks, as a category of monument, were seen to bear meaningful texts that transmitted wisdom; they were religious in purpose, honoring the gods and commemorating prayers; and their form was believed to refer to the sun's rays, the engine by which the sun transmitted energy and light to the earth.

Though all of these sources post-date the Augustan period, there is contemporary evidence to suggest that early imperial audiences may have viewed obelisks' symbolism similarly. First, there is significant debate about the date of Hermapion's book, of which the preserved section is just one part; some believe that it may belong to the early first century AD [Benaissa 2013]. Thus, it is possible that contemporary audiences had access, in some form, to information about the Egyptian language on Augustus' obelisks. Though this must remain a matter of speculation, it is also clear that there was popular interest in their inscriptions. Two extant cameo-glass vessels, a type of luxury-ware that was produced in Italy only during the early empire, depicted obelisks. One of them, today in the Getty Villa, included characters that were carefully modeled on Egyptian hierolgyphs - all 'real', though they do not preserve a word in its entirety (figure 15). This vessel, too, included a depiction of an Egyptian king making offerings at an altar with the obelisk in the background, confirmation of their seemingly

\footnotetext{
${ }^{54}$ Plin. HN 36.64: trabes ex eo fecere reges quodam certamine, obeliscos vocantes Solis numini sacratos. radiorum eius argumentum in effigie est, et ita sigificatur nomine Aegypto. ... etenim scalpturae illae effigiesque quas videmus Aegyptiae sunt litterae.
} 
religious function..$^{55}$ Above all, Augustus re-dedicated both obelisks to the Roman god Sol, or Sol Indiges, as evidenced by the inscriptions on their bases - deliberately playing upon their solar associations and known function as dedications, according to Roman understandings of their "Egyptian" symbolism. ${ }^{56}$

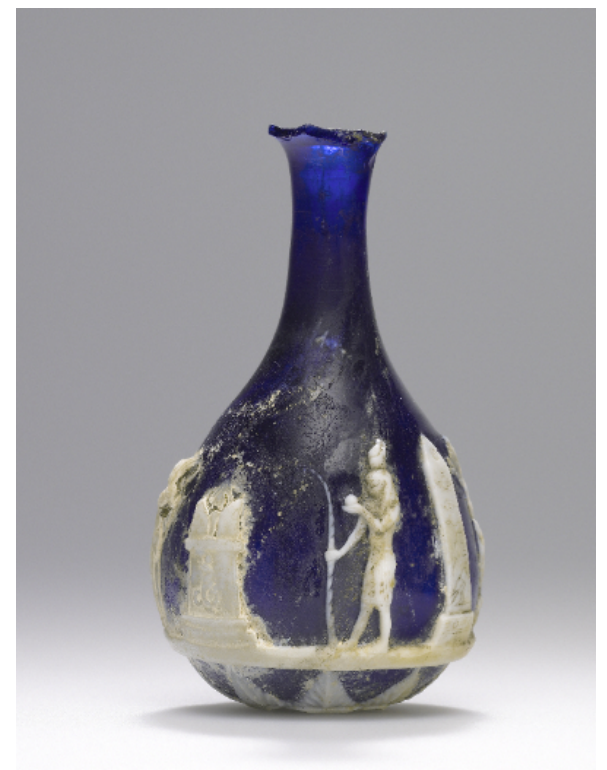

Figure 15. Roman glass flask, ca. 25 BC - 25 AD; J. Paul Getty Museum inv. 85.AF.84. Source: J. Paul Getty Museum.

Sol Indiges was the Latin version of the Sun god, and a deity featured prominently in the religious renaissance of Augustan Rome. There was a shrine to Sol in the Circus Maximus (which, in part, explains the dedication of the obelisk in that context), and the Augustan calendars reveal that rituals were performed in Sol's honor on August 9 on the Quirinal Hill, in commemoration of Julius Caesar's victory at Pharsalus. ${ }^{57}$ In addition, Horace invoked Sol in the Carmen Saeculare, performed in 17 BC. He addressed him as a god of rejuvenation ("Reviving Sol, you who in your gleaming chariot bring forth and hide the day, are born again and the same, may you be able to see nothing greater than the city of Rome") and equated him with Augustus' patron Apollo, echoing a religious association between the deities attested in Italy as early as the fourth century BC. ${ }^{58}$ The solar symbolism of the monument, combined with the close relationship between Sol and Apollo it suggested, resonated with themes prevalent throughout the art and literature of the period: agricultural fertility, healing, and rebirth and

\footnotetext{
${ }^{55}$ On the Getty flask, see Wight and Swetnam-Burland 2010; Swetnam-Burland 2015, and sources cited. For discussion of other fragments of cameo class, including one that shows an obelisk featuring 'fantastic' hieroglyphs, see van Aerde 2013.

${ }^{56}$ CIL 6.701, 6.702: Imp(erator) Caesar divi f(ilius) / Augustus / pontifex maximus / imp(erator) XII co(n)s(ul) XI trib(unicia) pot(estate) XIV / Aegupto in potestatem / populi Romani redacta / Soli donum dedit.

${ }^{57}$ Inscr. Ital. 13. 2.191 9: E V np Soli Indigeti in colle |quirinale fer(iae) q(uod) e(o) die |C. Caes(ar) c. f. pharsali devicit, "To Sol Indiges on the Quirinal Hill. Feriae, because on that day C. Caesar was victorious at Pharsalus." See also the Fasti Allifani, Inscr. Ital. 13 2.181; Fasti Antiates, Inscr. Ital. 13 2.208.

${ }^{58}$ Hor. Carm. saec. 9-12: alme Sol, curru nitido diem qui | promis et celas aliusque et idem | nasceris, possis nibil urbe Roma|visere maius. See on the role of Sol here Miller 2009: 279-81. For the early association of Usil (the Etruscan deity assimilated with Sol) and Apollo in Italy, see de Grummond and Simon 2006: 61.
} 
regeneration, much needed in the city's recovery after a long and bloody conflict. That Sol was honored in association with Julius Caesar's victories in civil war, too, reinforces this interpretation.

Better awareness of the Montecitorio obelisk as a monument with multiple and complex symbolic associations will enable deeper inquiries, considering its relationship with the other monuments of the Augustan Campus Martius afresh - as it related to the Egyptianizing elements incorporated in the Mausoleum, for instance, and to the lower friezes of the Ara Pacis, with their image of controlled but abundant natural landscape. ${ }^{59}$ On many levels, the Egyptian symbolism of the Montecitorio obelisk, as it was understood in Augustan Rome, enriched its function in the meridian. Because its form was understood as a representation of the sun's rays, the path the monolith traced on the pavement served as an ever-changing, yet perpetual, reminder of the sun's might. It made visible in shadow what could not be viewed directly by human eyes. As a symbol of Sol/Apollo, it echoed and reinforced an emerging Augustan ideology. And, as a symbol of Egypt's history and traditions, it proclaimed Augustus the new governor of the territory and the inheritor of its riches and wisdom.

\section{PTOLEMAIC BACKGROUND}

Jackie Murray

Although possible, as we have just seen in Swetland-Burland's contribution above, it remains hard to prove that Romans in the first century $\mathrm{BC}$ would have had direct access to Egyptian religious ideas from the pharaonic period about the sun and about how they informed monumental building. On the other hand, it is difficult to deny that Augustus and his contemporaries had direct access to the Ptolemaic version of these ideas and how they applied to contemporary monumental building in Egypt. Accordingly, it is worth coming to grips with certain fixed associations in Ptolemaic royal ideology, namely the fusion of Apollo and Horus and astronomical alignment, in order to make sense of why the Montecitorio Obelisk was dedicated to Sol. ${ }^{60}$

It is well known that as early as the fifth century Greeks identified their gods with those of the Egyptians, notably, for our purposes, Apollo with the Egyptian Horus [Hdt.2.144; 2.166.5]. On what grounds this equation was made is unclear, since Greeks in Herodotus' day probably did not understand the Egyptian religion of the time well enough to know all of the attributes of Horus, who was simultaneously the sun, the protector of the pharaoh and the living pharaoh himself. What concerns us is that the Ptolemies, who did have access to Egyptian religious ideas, promoted the integration of Apollo and Horus in Egypt and exploited the long-standing co-existence of Greek and Egyptian cults in Cyrene. There the syncretism of Apollo, the patron of the state, with Horus the divine pharaoh began early in its history as a Greek kingdom under the Battiad dynasty. Small votive Horus-falcons dating from the sixth century on into the Hellenistic age have been found in the extramural precinct of the sanctuary of Demeter [Warden 1990: 3-13], whom the Greeks identified with Isis. In the fourth century a temple to Isis was built adjacent to the Temple of Apollo in the center of the city, and beginning in the Ptolemaic period statues of Isis nursing Horus-the-Child were set up in the sanctuary of

\footnotetext{
${ }^{59}$ For illustration of the atef crown incorporated into the sculptural decoration of the Mausoleum, see de Vos 1980, frontispiece; for discussion, Söldner 2000; Schneider 2004, n. 76 for bibliography. For the Alexandrian-inspired construction of the mausoleum, see Davies 2000: 51-60. On the floral friezes of the Ara Pacis, which made reference in several ways to deities including Apollo and Dionysus, see Castriota 1995. For further dicussion of their role in the architectural program, see Pollini, section 8.

${ }^{60}$ On the relationship of theory and practice of Augustan and Ptolemaic rule in Egypt, see Herklotz 2007: $402-411$.
} 
Apollo [Paribeni 1959: no. 409-20]. The evidence of continuous worship of Horus from the archaic period into the Ptolemaic suggests that the Ptolemies were building on well-established foundations.

In Egypt, from Ptolemy Soter to Ptolemy Caesar, all the Ptolemies identified themselves with Horus and took on the five titles that the Egyptian religious conception of kingship demanded: Horus, Two Ladies, Golden Horus, Throne, and Son of Re. The Ptolemies also used the pre-existing Apollo-Horus as a cornerstone of their royal ideology. In Cyrene, Philadelphus' half-brother, Magas, was certainly exploiting the local Apollo-Horus syncretism when he took on the position as priest of Apollo in order to legitimate his position as king [SEG 18:743]. The youthfulness of the two gods seems to have provided important ground on which to merge them. Whereas Soter took a Horus name that emphasized his military prowess, "Horus whose might is great, the valorous ruler" (wr-pHti nsw-qnj [Naville 1890:62]), he did introduce from Sinope the syncretic cult of Serapis in which Harpocrates, Horus-the-Child, was prominent. Accordingly, when Philadelphus took his Horus name, he chose one that could link him to Harpocrates: "Child Triumphant" (Hwnw qnj [Lepsius 1849: vol. IV, plate $7 \mathrm{~g}$, Qus pyl]). The court poets helped articulate this fusion to the Greek-reading intelligentsia. Callimachus' Hymn to Delos [160-195] expresses the ideas behind Philadelphus' Horus name by associating the king closely with triumphant youthful Apollo [Koenen 1983: 174-190; Mineur 1984; Hölbl 2001: 111]. Callimachus' Hymn to Apollo also links the reigning Ptolemy to Apollo as the protector of kings: "whoever fights with my

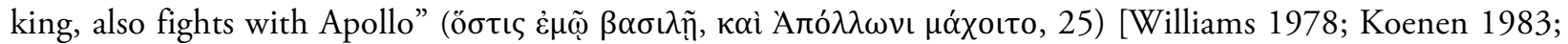
Bing 1988; Cameron 1995: 407-409; Stephen 2003; and, especially, Selden 1998]. As Selden 1998: 387 points out, outside of the Ptolemaic orbit, the presentation of Apollo as the protector of kings would have been an alien notion to a Greek audience. It was all the more alien when Hesiod's pronouncement on the matter is brought to mind contrasting Apollo's authority over poets with Zeus' authority over kings [Hes. Th. 94-96]. The innovative conjunction of kingship and Apollo's power in the Apolline hymns of Callimachus (who, not coincidentally, grew up in Cyrene) was introduced in a milieu where Apollo had long been assimilated to Horus [Selden 1998: 391-392]. By the reign of Ptolemy III Euergetes, people made very little distinction between Harpocrates, Horus-the-child and Apollo. ${ }^{61}$ The identification of the reigning Ptolemy with Harpocrates/Horus-the-Child persisted into Augustus' day. Cleopatra's father Ptolemy XII's elaborate Horus name reads:

The perfect youth, pleasant in his popularity, whose Ka distinguishes the Two Ladies with the people, who the wonderful Khnum praises so that he receives the crown as king, who unites himself with the works (of his father) in joy like that which his father protects, who is shining at birth on the throne of his father like Horus, the strong bull, the lord who lights up Egypt like the living Apis, to whom many great Sed festivals will be given through Ptah-Tennen, the father of the gods. ${ }^{62}$

\footnotetext{
${ }^{61}$ OGIS 89 where the dedication is made to Isis, Sarapis and Apollo. See Selden1998: 389-390.

${ }^{62}$ C. Bennett's translation 2001-2012 [http://www.tyndalehouse.com/egypt/ptolemies/ptolemy_xii_fr.htm] based on the transliteration from Lepsius 1849: IV, plate 49b: Hwnw-nfr bnr-mrwt Tnj-sw-nbt-rxyt-Hna-kA.fdwA.n.f-xnmw-Sps-r-Szp-n.f-xa(t)-mnsw snsn.n-sHnw-m-Haaw-mj-ND-jt.f THn-msw(t)-Hr-nst-jt.f-mj-Hr-kA-nxt jty-psD-m-tAmrj-mj-Hpw-anx rdj-n.f-HAbw-sd-aSAw$w r w-m j-P t H-t A T n n-j t-n T r w$.
} 
Caesarion's Horus name, "Perfect youth, pleasant in his popularity" (Hwnw-nfr bnr-mrwt), ${ }^{63}$ and his connection to Harpocrates was reinforced by Cleopatra, who, on monumental images, styled herself as Isis suckling him. ${ }^{64}$

Apollo also starts to take on Horus' solar attributes under the early Ptolemies, both in literature and in the public perception. In Apollonius' Argonautica, Apollo makes two epiphanies to the Argonauts. In the first, after the Argonauts come through the Clashing Rocks and are safely resting on a tiny deserted island reminiscent of Delos in the Black Sea, Apollo, whose youthfulness is stressed by the narrator, appears to them just before sunrise. Following Orpheus' instructions, they build an altar and worship the god as "the Lord appearing at Dawn," 'É́toc. They dance as Orpheus sings a hymn echoing the content of the Homeric Hymn to Apollo, all as if they were at Delphi [2.687-719]. Similarly, in an episode on their return voyage, Apollo appears again in response to Jason's prayers, and he brings the dawn back for the Argonauts after a sudden chaotic darkness endangers them [4.1690-1718]. ${ }^{65}$ Around the same time that this poem was produced, an inscription was set up in the precinct of the Serapeum to Apollo with the epithet Bladoui (A $\pi$ ó $\lambda \lambda \omega v \iota$ B $\lambda \alpha$ ó $\delta o v \iota)$. Selden argues convincingly that this otherwise unattested epithet of Apollo, B $\lambda \alpha$ ó $\delta$ ovı, is most likely "a deformation of an epithet of Horus, perhaps $B l-d w 3 y$, 'Eyes of the Dawn," which has a parallel in the ritual texts on the walls of the Temple of Horus at Edfu, which was begun under Ptolemy III and completed by Ptolemy XI, Cleopatra VII and her brothers [Breccia 1911: no. 168; Selden 1998: 389-390]. The Edfu texts refer to "Horus the Behdetite, the great god of the sky, who ascends on the horizon of the East ... his eyes illuminate the circle of the lands, he mounts the distant sky at dawn" [Selden1998: 390; Alliot 1949-1954: vol. 1, 414].

Monumental building was an important way in which the Egyptian king demonstrated his right to rule. From pre-dynastic times on, Horus was the god of monumental architecture, and building temples to the gods was thought to be a reenactment of the primeval creation of the world [Hornung 1992]. For Greeks, however, Apollo was not really a god of architecture or primeval creation in the same way Prometheus or Hephaestus was. He was, however, the god of creation in poetry and music, and in poetry Apollo is associated with building. In the Iliad, Homer says that Apollo and Poseidon built the walls of Troy [Il. 7.452-53]; in the Elegies of Theognis, Apollo built the walls of Megara [773-74]; and, most significantly, in the Homeric Hymn to Apollo, the god himself lays the foundations for his own temple at Delphi [287-95]. In support of the early Ptolemies' promotion of the synthesis of Apollo and Horus as primeval architect, Callimachus and Apollonius highlighted Apollo's connection to the construction of the temple at Delphi. In his Hymn to Apollo, Callimachus alludes to the image of Apollo building his temple at Delphi in the Homeric hymn in his own description of Apollo weaving the altar for himself and Artemis on Delos. Callimachus sets this event prior to Apollo's foundation of Cyrene in Libya, which in turn precedes his slaying of the snake Pytho. In effect, in Callimachus' hymn Apollo's building activity antedates his building of the temple in Delphi, making the altar on Delos and the laying the foundations of Cyrene the first acts of construction in the world [Selden 1998]. As noted above, Apollonius also uses the Homeric Hymn to Apollo as the primary intertext for the first epiphany of Apollo in his Argonautica. After celebrating Apollo 'É́tos, the Argonauts are inspired to swear an oath to protect one another forever and

\footnotetext{
${ }^{63}$ Lepsius 1849: IV, plate 61a.

${ }^{64}$ Cleopatra VII struck coins on Cyprus some time after Caesarion's birth depicting him at her breast with the double cornucopia on the reverse and with the legend "Cleopatra the Queen"; for the images see Poole 1883: ix-xxiii (pl. xxx,6), Walker and Higgs 2001: 178 (cat. No. 186). For discussion of the monuments depicting Cleopatra as Isis suckling Osiris, see Tyldesley 2008: 118-122.

${ }^{65}$ On the date of the Argonautica see Murray 2014: 247-284.
} 
to build a shrine to the goddess Opovoí $\alpha$, Concord, to commemorate the oath. And according to the narrator the shrine was still standing in his day [2.685-719]. This picture Apollonius paints frames all the monumental building of the Ptolemies in terms of pious devotion to the gods that has its model in the heroic age.

The Ptolemies pursued a policy of active temple building to make their rule consonant with ancient pharaonic ideology about the king's role. This led to a proliferation of temple architecture, especially in the south [Hölbl 2000: 257-285]. Here it is worth focusing on the Temple of Horus at Edfu, because of its connection to Apollo. It is the best preserved of all Ptolemaic temples and its building inscriptions provide details from every phase of construction [Cauville and Devauchelle 1984]. It was started at the high point of the dynasty by Ptolemy III Euergetes in $237 \mathrm{BC}$, the year following his jubilee and his introduction of the first calendar with 365 and onequarter days, the basis of the Julian calendar [Pfeiffer 2004]. The inscription describes the initial act of foundation, i.e. the stretching of the cord to determine the proper cosmic alignment. What is interesting in this inscription is that Ptolemy III claims to have observed the Egyptian constellation Meskhet(yu), which corresponds to our Big Dipper, while carrying out the stretching of the cord ceremony with the goddess Seshat [Chassinat and Cauville 1990: 31, 2ff; Wainwright 1932: 373]. This claim is repeated by his son Philopator 25 years later in $212 \mathrm{BC}$ [Furth et al. 2004: 44, $7 \mathrm{ff}$ ]. The inscription preserves the earliest explicit statement that astronomical observation was involved in aligning temples in Egypt [Belmonte et al. 2009]. Egyptologists are not completely in agreement about exactly how observation of this constellation determined the alignment, but there is general consensus that astronomical observation best explains the near perfect North-South axis of the Temple, which is significantly different from the earlier pharaonic era Birth-House, the axis of which is roughly East-West [Zaba 1953: 58-73; Shaltout and Belmonte 2005: 273-298; Leitz 1989; Waitkus 1983]. Regardless of exactly how observation of the the constellation factored into the physical orientation of the Temple, it certainly was consistent with contemporary Ptolemaic royal ideology. It can hardly be coincidental that the same king who brought order to the heavens by introducing a new calendar is also the king who initiated the building of the temple to Apollo by aligning its foundations to the heavens. The final phase of construction was finished by Ptolemy XI Auletes in 57 BC, leaving the decorations and statuary to Cleopatra VII and her brothers. Ptolemy XIII is depicted on the pylons in the traditional pharaonic smiting scene, whereas in front of these pylons Cleopatra added the large Horus falcons protecting an almost life-size Caesarion. These images express Ptolemaic kingship and imperial ambition in traditional Egyptian terms.

Let us return now to Rome, to the Campus Martius where we observe the triple alignment of the sun-obeliskAra Pacis on many days of the year. The obelisk, in its original Egyptian context in Heliopolis, was a symbol of pharaonic conquests and Egyptian empire. Thus, its transportation and re-erection in Rome enacted the conquest it commemorates as well as the reorientation of the imperial center of the world from Egypt to Rome. The Ara Pacis commemorates all of Augustus' conquests, which amount to an end of all wars, an end to the succession of empires.

Bringing to bear the aspects of Ptolemaic royal ideology that we have been discussing sheds some light on how these three monuments work together. First, Roman Apollo was not the archaic or classical Apollo of the Greeks. Roman Apollo was born in the Hellenistic era. Roman Apollo was a Sun god and, as argued above, it was under 
the influence of Ptolemaic royal ideology that Apollo became strongly marked as a Sun god ${ }^{66}$ In other words, the Apollo Augustus identifies with was closely related to the Ptolemaic Apollo-Horus. That being the case, Dundas' observations about the changes that Augustus made to the traditional pharaonic titulary gain significance in relation to the conjunction of the sun, the obelisk, and the Ara Pacis. Whereas the Ptolemies maintained the traditional five-part protocol, Augustus reduced it to one, the Horus name. The short version of his Horus name is usually simply Autokrator, but the longer version ends with this remarkable phrase: "...whose power is incomparable in the city par excellence that he loves, Rome" [translation by Dundas 2002: 445; see Grenier 1995]. As Dundas points out, Augustus' Horus name is a declaration that Rome has been chosen by the god over Egypt as the new center of the world. Hence, we might be tempted to read the conjunction of the sun, the obelisk, and the Ara Pacis as an expression of Augustus' Horus name in monumental terms.

\section{AUGUSTUS' RÔLE AS PHARAOH OF EGYPT - PAX AUGUSTA - GOLDEN AGE - FELICITAS TEMPORUM - ARA PACIS ${ }^{67}$}

Chrystina Häuber

In $30 \mathrm{BC}$, Octavian/Augustus became the pharaoh of Egypt and, as such, was believed by the Egyptians to be the son of the sun god Re. ${ }^{68}$ The claim, "I, Augustus, am the son of the sun god (Apollo/Re)," ${ }^{69}$ is made visible by the Ara Pacis, and no other Augustan building would better qualify to convey this message. In particular, the iconography of the Ara Pacis, of course, shows the achievements of Augustus' reign, but those blessings are exactly the same that the king of Egypt in pharaonic times had long been expected to bestow upon his people. The sun god Re was (among other things) the force that enabled the pharaoh to provide his subjects with these benefits. Therefore, the pharaoh was the bringer of prosperity because his most important duty-to be realized by actions and rituals he had to perform on a daily basis or on special occasions — was to establish Maat ("world order") [Assmann 2006]. The pharaoh's establishment of Maat resulted in justice and peace on earth and in the sphere of the gods [Herklotz 2014: 221 with n. 595], resulting in universal prosperity for his people. ${ }^{70}$

Precisely these positive results of the monarch's reign were represented on a marble altar at Praeneste, which was dedicated posthumously to the deified Augustus (figure 16). On it Augustus is seen wearing a radiate crown, the (lost) metallic parts of which, representing the rays of the sun, were inserted into holes drilled into the marble. The cornucopiae on this altar symbolize, according to Zanker, the universal prosperity brought about by Augustus. In his discussion of this altar, Zanker also mentions the Ara Pacis as "symbol of peace and of

\footnotetext{
${ }^{66}$ To be sure, there are earlier attestations of the association of Apollo with Helios (e.g., Euripides, Phaethon fr. 781.11-12, a reference I owe to an anonymous referee of this article, who justly writes, "Ptolemaic ideology presumably built upon this association rather than inventing it").

${ }^{67}$ The ideas presented here are discussed in more detail in Häuber 2016.

${ }^{68}$ Hölbl 2004; Herklotz 2007: 209-220 with n. 589, and passim, p. 209; Häuber 2014: 735 with n. 68.

${ }^{69}$ Herklotz 2007: 209-211 with nn. 519, 520; pp. 218-219, 220 with n. 589; pp. 227-228.

${ }^{70}$ Goyon 1988: 29-30; Goyon 1989: 33-34; Häuber 2014: 733-735; Assmann 2006: 226-228.
} 
universal well-being" ${ }^{11}$ because both monuments express basically the same meaning. ${ }^{72}$ Clearly, the Ara Pacis is the building par excellence celebrating Augustan peace and prosperity. The message of the marble altar in Praeneste turns out to be that Augustus ${ }^{73}$ was the founder of a new Golden Age—hence the cornucopiae —and thus the guarantor of prosperity and of temporum felicitas ("felicity of the times"). Needless to say, the prerequisite of all this was peace. Berges has observed that the iconography of the altar's fruit-laden cornucupiae with globular lower end resembles the famous Ptolemaic dikeras ${ }^{74}$ (two parallel cornucopiae). According to Rice, "the dikeras, filled to overflowing ... obviously emphasizes the role of the monarchs [of Egypt, king Ptolemaios II and his wife Arsinoe II] as the joint source of blessings and abundance to the kingdom." 75 was to develop into the attribute par excellence of the wealth and tryphe ("opulence") of Ptolemaic rulers, and hence of Egypt.

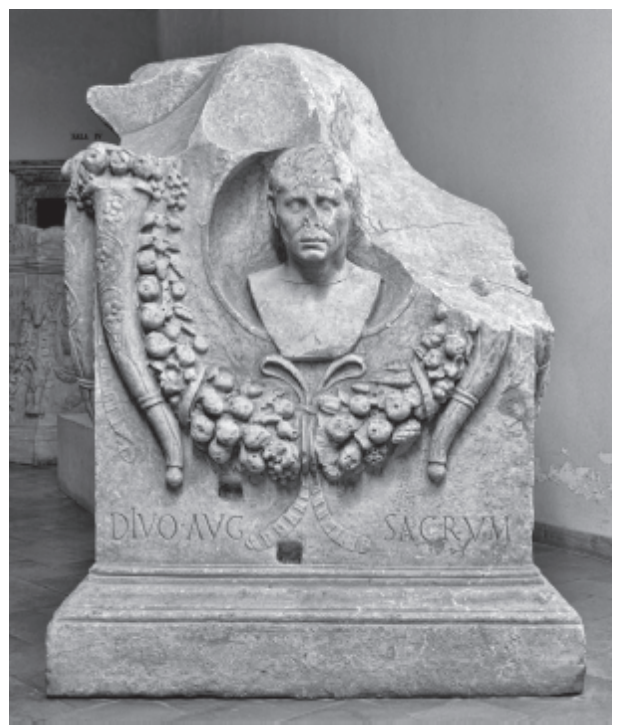

Figure 16. Marble altar dedicated to Divus Augustus. Museo Archeologico Nazionale, Palestrina.

Thus Berges notes "the tangible promise of prosperity, which is expressed by the cornucopia," and further interprets the "unusual altar" in Praeneste in this way: "it is certainly no accident that this motif [scil., of the cornucopia] appears on a monument which was dedicated to Augustus, the founder of imperial rule in Rome, who at the same time inherited power from the Ptolemies, and whose domestic program strove to communicate

\footnotetext{
${ }^{71}$ Zanker 2006: 325, caption of fig. 240: “... Il ritratto di Augusto era munito di una corona di raggi. Le cornucopie indicano in lui l'artefice della prosperità universale."

${ }^{72}$ Cf. Häuber 2014: 716 n. 240, quoting Zanker 2006: 325, caption of fig. 240 (on the altar, here figure 16); cf. p. 334, caption of fig. 247: "Altare da un santuario per la gens Augusta, eretto a Cartagine dal liberto P. Perellio Edulo. Roma con la Vittoria davanti a un monumento che celebra la pace e la prosperità universale. Prima età imperiale;" pp. 333-334 on the same relief of this altar: “... La composizione va intesa come una versione semplificata di quelle che è, sull'Ara Pacis, la coppia Roma-Pax ... simbolo della pace e del benessere universale;" cf. Zanker 1987: 304, fig. 240.

${ }^{73}$ For “... zwei antithetisch aufgestellte Füllhörner als Zeichen des goldenen Zeitalters [in the Augustan period].” See also Schneider 1997: 103; Pollini and Cipolla, in section 7 below: "An implied sexual connection between the obelisk and the Ara Pacis would have highlighted Augustus' bringing to the world felicitas (good fortune), with its attendant fertility and prosperity, requisite for the rebirth of the Golden Age."

${ }^{74}$ Berges 1995: 103; Häuber 2014: 714 with n. 223 and 603 with n. 15.

${ }^{75}$ Rice 1983: 203, 204; Häuber 2014: 604 with n. 24.
} 
through the concept of Pax Augusta the same promise of prosperity which long before him the Ptolemies had expressed through the imagery of the dikeras." 76

The Praeneste altar was dedicated to Divus Augustus posthumously, but we can nevertheless be sure that he himself was quite familiar with the meaning of the iconography. On one of the first coins that he minted in Alexandria (before 9/10 AD) a portrait of his wife Livia appears on the obverse with the legend Livia Sebastou ("Livia, the wife of Augustus"). On the reverse we see the legend Patros Patridos (referring to Augustus' title Pater Patriae, bestowed upon him in $2 \mathrm{BC}^{77}$ ) as well as the Ptolemaic dikeras (two parallel cornucopiae), which contain, as usual, poppies and ears of wheat and are wound about with a tainia (the royal diadem of the Ptolemies). At about the same time Augustus issued coins in Alexandria with a portrait of himself on the obverse with the legend Pater Patridos and on the reverse the dikeras with the legend Sebastos ("Augustus") [Häuber 2014: 715, n. 234]. He could not have chosen better iconographic motifs to proclaim that now the imperial couple guaranteed "prosperity" ("Wohlfahrt," Berges) in exactly the same fashion as the Ptolemaic rulers had done.

Considering what was said above, we may ask ourselves whether or not the ideological basis for Augustus' claim to good leadership is actually indicated in the iconography of the Praeneste altar, viz., the radiate crown worn by Augustus (figure 16). We know that he was the first Roman emperor to wear a radiate crown [Bergmann 1998]. The hypothesis proposed here can only be true if the sun-rays must be explained by the fact that Augustus was also the first Roman leader who was the pharaoh of Egypt and thus believed by the Egyptians to be the son of the sun god Re. ${ }^{78}$ Here, again, as with the cornucopia, Augustus' precedent came from Ptolemaic royal imagery [Bergmann 1998: 112-115]. As observed by Musso, the Roman emperor was regarded as "parens mundi, producer of good governance and in turn governor of fate. In the official terminology, the quality of guarantor of the cosmic order is transmuted into imperial virtue." ${ }^{79} \mathrm{La}$ Rocca writes under the rubric "Augustus' political vision" that "Augustus was born for the welfare of mankind" [La Rocca 2014, 157]. All this sounds exactly like the theological construction of the image of the Egyptian pharaoh, as discussed above. In a relief at the temple of Esna in Egypt, the emperor Caracalla is shown as pharaoh in the act of harvesting wheat, and the inscription calls him "guarantor of fertility and nourisher of the people." ${ }^{00}$ The inscription on the Antinous obelisk at Rome even reads: "Hadrian, supported by the Nile god, is the guarantor of fertility for the entire world." ${ }^{11}$

\footnotetext{
${ }^{76}$ Berges 1995: 95 with n. 25; p. 103 with n. 64; Taf. 26,3, which quotes Zanker 1987: 304. German passages translated by B. Frischer.

${ }^{77}$ Cf. R. Hanslik, s.v. Augustus, Der Kleine Pauly, vol. 1, 1979, col. 752; Häuber 2014: 715 with n. 232.

${ }^{78}$ For other interpretations, cf. Musso 2000: 378; Frischer, below section 11, on the Ara Providentiae.

${ }^{79}$ Musso 2000: 378 with nn. 64, 65; cf. Häuber 2014: 715 with n. 231. Italian translated by B. Frischer.

${ }^{80}$ Hölbl 2004: 529 with n. 14, fig. 7; Häuber 2014: 736 with n. 71.

${ }^{81}$ Hölbl 2004: 529; Häuber 2014: 736 n. 72.
} 


\title{
7. THE BIRTH OF AUGUSTUS, THE SOLARIUM AUGUSTI, AND THE LIFE-GIVING ASPECTS OF APOLLO AND SOL IN AUGUSTAN VISUAL CULTURE
}

\author{
John Pollini ${ }^{82}$ with Nicholas Cipolla
}

In $12 \mathrm{BC}$, Augustus became Pontifex Maximus, a position that gave him control of the Roman calendar and thereby also, in a sense, control of time itself. One of his first and most important tasks as supreme pontiff was to correct the Julian calendar following an error introduced by the pontifices shortly after Julius Caesar's death. ${ }^{83}$ To correct this mistake, which may have involved the inclusive Roman method of counting intercalary days, and to check the Roman calendar on a daily basis throughout the year, Augustus made plans for a great calendrical meridian line, to be laid out in the open space of the Campus Martius [cf. Macrobius, Sat. 1.14.1315]. The meridian made use of an Egyptian obelisk for its pointer, or gnomon. The meridian line and gnomon functioned together as a calendrical "solar device," or calculator. ${ }^{84}$ For the pointer of this special type of solarium, an obelisk originally set up by the Pharaoh Psametik II (594-589 BC) at Heliopolis, Egypt was erected in the Campus Martius in Rome. ${ }^{85}$ The very transporting of such granite behemoths on specially constructed ships was itself considered a wondrous feat of Roman engineering that was credited to Augustus. ${ }^{86}$ To immortalize his victory over Cleopatra (and Antony), which also marked the end of the Roman civil war period, this obelisk in its new context was made roughly 100 Roman feet high, a number that had great symbolic value, since the Roman numeral C (= 100) was closely associated with the concept of immortality and eternity. ${ }^{87}$ In order to

\footnotetext{
${ }^{82}$ I would like to thank Bernard Frischer, Paolo Albèri Auber, David Dearborn, and Matthew Brennan for information and discussions about various aspects of the Solarium - Ara Pacis complex and the new Frischer-Fillwalk Virtual Meridian Simulation. Special thanks are also owed to Nicholas Cipolla, who collaborated on the models for my book (Pollini 2012), and for discussion and comments on both of my essays published in this series of contributions. In addition, I thank Lothar Haselberger for inviting me to participate in recent scholarly discussions regarding the Solarium (Horologium) Augusti and to contribute an article in a collection of essays published in JRA Suppl. 99 (2014) 53-61. To reduce the bibliography to a minimum, I have cited where applicable my recent book (Pollini 2012), in which a number of these themes have been explored at greater length and with further bibliography. New ideas and observations are also incorporated here. See also in general Galinsky 1996.

${ }^{83}$ See Stern 2012: 214-216, nn. 163-164.

${ }^{84}$ A scholarly debate has arisen on the use of the correct terminology to describe both the meridian and the colossal obelisk used as its gnomon, since objections have been raised to referring to these two objects together by the synonymous terms horologium and solarium, both of which are commonly used to mean a "sundial" in the sense of a diurnal clock. For this debate, see most recently Haselberger 2014: 171-73. In fact, neither term was used in the ancient sources to describe Augustus' meridian with its obelisk gnomon-pointer. Since the word horologium puts emphasis on the horae, or hours of the day, we prefer to use the term solarium in describing this gnomon-meridian device for no other reason than the term solarium places emphasis on the "sun," and therefore literally means in Latin a "sun thing/device." Consequently, we employ the modern term "Solarium Augusti" to describe the gnomon-meridian in the sense that it was a calendrical solar device. For a discussion of the various types of solaria, see Varro (Ling. 6.4) and Pliny (HN 7.214). See also Cicero (Nat. D. 2.87) for the seemingly odd use of the term solarium ex aqua for a water clock.

${ }^{85}$ For this obelisk, see Swetnam-Burland 2010: 53. Another colossal obelisk imported by Augustus was that of Seti I, later erected by his son Rameses II. This obelisk was set up originally on the spina of the Circus Maximus, but was re-erected in modern times in the Piazza del Popolo. Pliny (HN 36.71) confuses these two obelisks and their original locations.

${ }^{86}$ For a description of the transportation of such colossal obelisks, the ships used to carry them, and the obelisk that Augustus set up on the spina of the Circus Maximus, see Pliny (HN36.70).

${ }^{87}$ This is implied by the predilection for propitious hundred-foot monuments among both the Greeks (e.g., hekatompedon temples) and the Romans (e.g., the colossus of the god Sol set up by Nero, as well as the Columns of Trajan and of Marcus Aurelius). Also relevant is the anecdote recounted by Cassius Dio (56.29.4) that a thunderbolt (a divine sign) struck a statue of Augustus on the Capitoline and obliterated the "C" in his (inscribed) name "Caesar." This led seers to conclude that 100 days hence Augustus would attain divine status, thus becoming a god (divus), as he did, since the word "Caesar" is composed of the letter "C," signifying 100
} 
achieve this height (ca. $29.60 \mathrm{~m}),{ }^{88}$ a granite base and a once gilded bronze finial, or top ornament, were added to the obelisk's shaft, which originally stood only $21.79 \mathrm{~m}$ high. ${ }^{89}$ The shadow cast by the obelisk with its finial would have fallen along the long bronze meridian line with short bronze cross-bar markers (regulae), which was laid out on large white travertine flagstones with markings indicating the path of the sun at noon each day over the course of a year, probably from about $9 / 8 \mathrm{BC}$ on..$^{90}$ Bronze letters in Greek for the signs of the zodiac and the winds were also set into the travertine pavement of the meridian to indicate the periods and seasons of the year. As Pliny tells us [HN 36.72], the gilded sphere that formed part of the finial was attached to the pyramidion, the pyramid-shaped capstone of the obelisk, to give greater clarity or definition to the shadow cast on the meridian line, an arrangement inspired by the shadow cast by the head of a human body.

As with Augustus' other great urban projects in Rome, his calendrical Solarium would serve both a practical and an ideological function. Besides its use as the gnomon for the meridian, there were a number of important symbolic and ideological aspects to Augustus' obelisk, especially in connection with the nearby Ara Pacis Augustae and more distant Mausoleum Augusti. In Egyptian religion, rose-colored granite obelisks are sacred to the sun god Re, and their pyramidion-shaped capstones, probably gilded, are symbolic of the triangle that the sun's rays form, especially when seen on a cloudy day as they break through clouds. In fact, as Pliny [ $H N$ 36.64] tells us, the Egyptian word tekhen is the same for "sunbeam" and "obelisk." Rose-colored granite used for obelisks was emblematic of the fiery sun itself and was understood as such even in Roman times, as suggested by the Greek word pyrrhopoekilos ("red-spotted") for this type of bespeckled rose-colored stone [Pliny $H N$ 36.64]. In discussions about the significance of the sun and the Obelisk of Augustus, it has been generally overlooked that engraved in negative relief at the very pinnacle of the four sides of the pyramidion of this obelisk is the sacred Egyptian scarab, symbolic of the creator god Khepri, pushing the solar disc across the heavens over the course of the day.

among the Latins (Romans), while the rest of the name "aesar" signified "god" among the Etruscans. Secondarily, Roman architects liked even numbers, especially multiples of 10 units. It was also well known that the Greek philosopher Pythagoras had established 10 as the perfect number, since it contained in itself the first four integers - one, two, three, and four $[1+2+3+4=10]$. The isosceles triangular figure (tetractys), produced when ten points are arranged in four rows with one, two, three, and four points in each row, became a mystical symbol. The number 100 (i.e., $10 \times 10$ ) might be thought to be beyond a human concept of perfection and thus came to be associated with the divine, as well as with immortality and eternity.

${ }^{88}$ The Roman pes ("foot") as used in various monuments and buildings varies from ca. 29.40 to $29.60 \mathrm{~cm}$. We thank Robert Cohon for discussions on this matter and permitting us to read his article before it was published. See now Cohon 2015, especially 80-81.

${ }^{89}$ We are skeptical about the two separate phases proposed by P. Albèri Auber 2011-12: 469, 501; 2014: 68-69; namely, that the meridian and the spherical finial which were added to the obelisk were part of some practical "afterthought" or secondary plan after the obelisk had been set up to serve only an ideological need (i.e., as a victory monument). In our opinion, the obelisk and the meridian would have been planned together from the outset shortly after Augustus became Pontifex Maximus, when he then had the right and duty to rectify problems with the calendar. This "unitary project" was proposed by E. Buchner and L. Haselberger: See Haselberger 2011: 53-55, and his recent criticism of Albèri Auber on this matter, 2014: 193-94. There are too many unknowns to be definitive on this matter. Nevertheless, this problem deserves further study. In any case, even if there were two distinct phases, the meridian would most likely have been in place very soon after the setting up of the obelisk, probably at the latest by $8 \mathrm{BC}$, several years after the Julian calendar was recognized to have been in error. If it were a two-step process, the addition of the finial would have given even greater meaning to the relationship of the monuments.

${ }_{90}$ The year $8 \mathrm{BC}$ was the final year that an incorrect intercalary day was inserted into the Julian Calendar. After that year Augustus suspended all leap years until AD 4 in order to correct the calendar. See Stern 2012: 214-15 with nn. 161-62. 


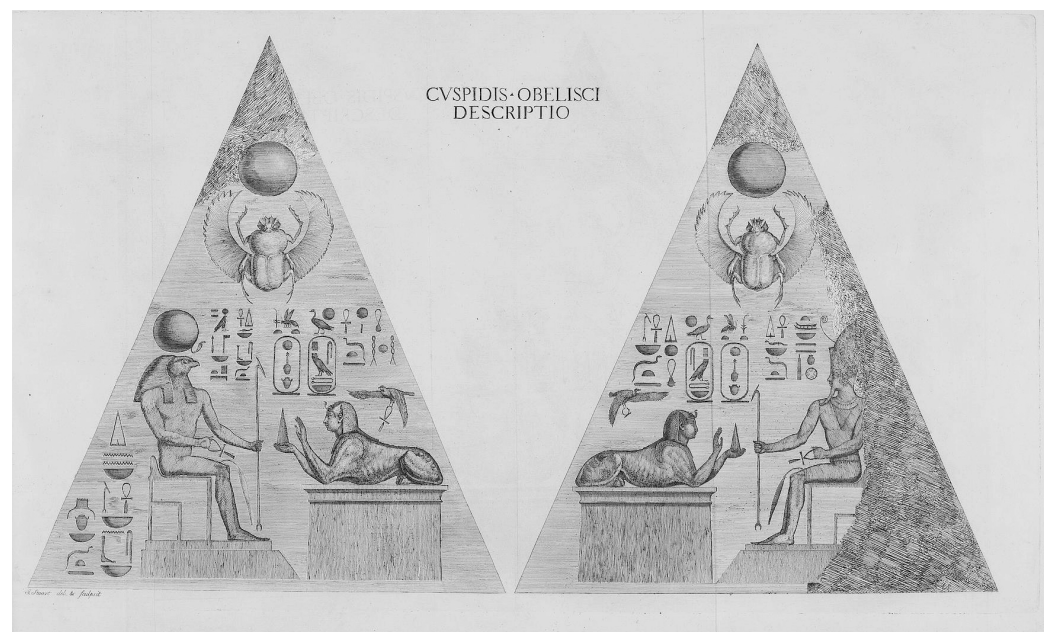

Figure 17. James Stuart's engraving of the pyramidion of the Montecitorio Obelisk; Bandini 1750: plate III.

This engraved image, drawn by Stuart in the mid- $18^{\text {th }}$ century from the fallen obelisk (figure 17), finds an analogue in the movement of the obelisk's shadow over the course of the day. ${ }^{91}$

Though generally also not commented on, the gilded sphere affixed to the top of the pyramidion of Augustus' obelisk suggested the very form of the sun in all its golden brilliance and was symbolic of the sun god Re, who in this new Augustan context was to be thought of as the Roman sun god Sol (or Helios, as he was known to the Greeks). The pertinent part of the Latin inscription on the base of the obelisk makes clear that it was to be understood as a Roman victory monument dedicated to Sol: Augustus... Aegypto in potestatem populi Romani redacta Soli donum dedit (“... with Egypt restored to the power of the Roman people, Augustus dedicated [this] to Sol”) [CIL 6.702 = ILS 91]. With Egypt again under Roman sway, Augustus had now become the direct successor of the Ptolemies and the official upholder of ancient Egyptian religious traditions. ${ }^{92}$

But victory was only one of the two principal pillars of Augustus' verbal and visual ideology; the other was peace. The Roman concept of "peace through victory" was, in fact, one of the fundamental ideological messages of Augustus' great urban projects, or as Augustus himself expressed it more fully in his Res Gestae (13): per totum imperium populi Romani terra marique ... parta victoriis pax ("throughout the entire empire of the Roman people, both on land and sea peace [was] brought forth by victories"). ${ }^{93}$ For this reason, the base of Augustus' obelisk was set in near axial alignment with the Ara Pacis Augustae ("Altar of Augustan Peace"), a pendant monument voted by the Senate in 13 BC. The Ara Pacis was located just under $90 \mathrm{~m}$ to the east of the obelisk. At a distance

\footnotetext{
${ }^{91}$ Because of the height of the obelisk and the slope of the pyramidion, this feature is almost imperceptible from the ground. For this illustration, see Stuart 1750, pl. III. For the hieroglyphs on the obelisk, see Ciampini 2004: 142-49 (no. 6).

${ }^{92}$ Prior to Octavian's conquest of Egypt in $30 \mathrm{BC}$, the country under the Ptolemies had become so weakened that it became de facto a protectorate of Rome -- hence Caesar's intervention on the matter of who would rule Egypt. This is why the specific verb redacta ("having been restored/brought back") is used with Aegyptus (f.) in the dedicatory inscription. Importantly, Julius Caesar was probably first introduced to the Egyptian solar calendar when he was in Alexandria in $48 \mathrm{BC}$. He is also said to have planned to improve on the calendar of Eudoxos of Cnidus (fourth century BC): See Luc.10.186-187. Pliny (HN 18. 211-212) mentions that Sosigenes of Alexandria assisted Caesar in the implementation of the new Julian calendar.

${ }^{93}$ For the Roman concept of "peace through victory," see Pollini 2012, especially 178-190.
} 
of about 35 to $36 \mathrm{~m}$ to the east of the Ara Pacis and running parallel to it was the Via Flaminia (Via Lata), the roughly north-south main thoroughfare leading out of Rome which Augustus himself had recently restored $[R G$ 20]. In order for the calendrical Solarium to function, the meridian had to be placed in north-south alignment at an angle of about $15^{\circ}$ to the axis of the obelisk. Together, the Solarium, with its obelisk/gnomon celebrating victory, and the Ara Pacis, heralding Augustan peace, would convey Augustus' principal ideological concept of "peace through victory." Of all his achievements, peace through victory was his most important and the one that would eventually lead to his apotheosis after death, as even Ovid recognized in his Metamorphoses [15.86870].

Augustus' birth and accomplishments in life were connected symbolically with his death and future deification through the axial alignment of the obelisk and his great dynastic Mausoleum to the northwest. As testimony to his right to apotheosis, Augustus indicated in his will his desire that his achievements be engraved on bronze tablets flanking the entrance to his Mausoleum [Suet. Aug. 101.4]. ${ }^{94}$ At the heading of this posthumous public record of his official accomplishments were the words Res Gestae Divi Augusti [see also Suet. Aug. 101.2]. In this way, the Solarium-Ara Pacis complex was brought into an intimate relationship with the Mausoleum Augusti, which had been finished around 25 BC. From the optimum viewing angle of these three monuments, an observer could synoptically appreciate the concept of peace through victory leading to the apotheosis of Augustus, whose image atop his Mausoleum most likely represented him in a triumphal chariot (in quadrigis) to celebrate his triple triumph in Rome in $29 \mathrm{BC}$, just after construction had commenced on his great dynastic tomb. With such a quadrigate image towering over the Campus Martius at a height of about 150 Roman feet, Augustus would have appeared to an approaching viewer (especially from the south) as though he were ascending to heaven like Romulus in the chariot of his father Mars, an event which is said to have occurred to the south near where the Agrippan Pantheon was built. ${ }^{95}$

As in the case of dedications of Roman temples, association with imperial birthdays and anniversaries also played an important role in the Solarium-Ara Pacis complex. ${ }^{96}$ The Ara Pacis itself was dedicated on January 30 in 9 BC, the 50th birthday of Augustus' wife Livia. As for the obelisk, the inscription on its base indicating offices held by Augustus makes it clear that the obelisk was dedicated around the same time, between June of 10 and June of 9 BC. In my view, the specific date is likely to have been the birthday (dies natalis) of Augustus, on September 23 in 10 BC. That year marked the vicennalia (20th anniversary) of Augustus' great military success over Cleopatra. It is also noteworthy that Augustus' 50th birthday fell in the year 13 BC, when the Ara Pacis was constituted (constitutio) by the Roman Senate. ${ }^{97}$ Even in the Roman provinces, Augustus' birthday was a significant occasion; for example, at the time of the construction of the Solarium-Ara Pacis project in Rome, the Koinon of the Hellenes in Asia (Minor) voted that their New Year begin on Augustus' birthday. Recognizing

\footnotetext{
${ }^{94}$ Buchner discovered the foundations of these two pillars: Buchner 1996: 161-68; Pollini 2012: 251, pl. XXVIII.

${ }^{95}$ For these ideas, including new models of the Mausoleum Augusti and the circumstantial evidence for the image of Augustus atop his Mausoleum being of the quadriagate form rather than the assumed statua pedestris (on foot) type, see Pollini 2012: 248-56 with further bibliography.

${ }^{96}$ For the six Roman temples that we know were rededicated on Augustus' birthday (Sept. 23) after restoration, see Gros 1976: 33-34. Although the Ara Pacis was not an aedes (a "temple" in the modern sense of the word), it was a templum in Latin terminology, in that it was a sacred inaugurated precinct, marked out on the ground by augurs: Pollini (2012) 227. This was also true in the case of the majority of Roman aedes.

${ }^{97}$ For a discussion of the constitutio in relation to the inauguratio of the Ara Pacis and the event represented on the two processional friezes of the altar, as well as its dedicatio and consecratio, see Pollini 1978: 95-99.
} 
the importance of that date, Buchner, who excavated a section of the Augustan meridian, concluded that the shadow cast by the obelisk pointed directly toward the center of the Ara Pacis in the afternoon of Augustus' birthday on September 23, indicating that Augustus was born to bring peace to the world ("natus ad pacem"). ${ }^{98}$

The new simulations published here are based on Frischer's forthcoming correction of Buchner's positioning of the meridian fragment and obelisk on the map of contemporary Rome, and they also update the position of the shadow in relation to the Ara Pacis on Augustus' birthday. They show that at that time the shadow of the obelisk with its finial fell on the western staircase of the altar (figure 18). The inscription of the Koinon of the Hellenes also noted the felicitous and momentous near-coincidence of his birthday with a cosmic event, namely, the autumnal equinox. ${ }^{99}$ Augustus' birthday would in all probability have been highlighted with a sacrifice at the altar in the afternoon, when priests and spectators would have witnessed the penumbral shadow of the obelisk falling on the staircase leading to the entrance. ${ }^{100}$ Although the shadow pointed toward the Ara Pacis on other days as well, the birthday sacrifice would have given special meaning then to the location and orientation of the shadow of the obelisk with its finial. ${ }^{101}$ To be sure, the shadow would have been somewhat diffused by the time it reached the Ara Pacis' western (front) entrance at around 4:22 pm (=16:22 CET). ${ }^{102}$ Nevertheless, it would still have been clearly visible, especially on the white marble stairs, as calculations of the penumbra of the obelisk's sphere and comparative studies of the shadows of other obelisks have shown. ${ }^{103}$ The shadow of the obelisk's finial would have fallen near the top of the staircase (figure 18), or may have just pierced the western entrance of the Ara Pacis on September 23 and September 24 (figure 19), ${ }^{104}$ while on September 26, the darker, umbral shadow of the shaft of the obelisk itself would have pierced this entrance. This phenomenon would have had great visual symbolism, as we shall see. ${ }^{105}$ We may note here that Augustus' birthday was actually celebrated formally on both September 23 and 24 - a biduum ("double-day") celebration. ${ }^{106}$ It is therefore quite possible

\footnotetext{
${ }^{98}$ For this neologism, see Buchner 1982: 37.

${ }^{99}$ Haselberger 2011, no. 12 and 2014: 34-35 with further references.

${ }^{100}$ Sacrifices were made to Augustus' genius on many occasions and in many places by vote of the Senate starting in 30 BC: Cassius Dio, 51.19.7. See also Taylor 1931: 151-52; Pollini 2012, especially 330-31 et passim.

${ }^{101}$ It is important to remember that such an alignment happens twice a year, once in the fall and once in the spring. We thank Bernard Frischer for emphasizing this point. The alignment in the fall (September 23) is clearly the more important one, since that was the birthday of Augustus, when a crowd would have gathered for the birthday sacrifice, as noted above.

102 The shadow shown in some simulations is slightly darker than it would have been in reality because the simulation does not represent penumbral (soft) shadows accurately. See here, however, figures 18-19, which show more accurately the penumbral shadow of the finial.

${ }^{103}$ We thank astrophysicist Dr. David Dearborn of NASA Ames Research Center for calculating the degree of saliency of the penumbral shadow at a distance of ca. $90 \mathrm{~m}$ (only $32 \%$ as bright as the surrounding sunlit area) and corroborating that the shadow of the obelisk with its sphere-and-spike finial could indeed be seen at that distance. For an approximation of the diffusion of this penumbral shadow based on the shadows cast by actual obelisks, cf. Pollini 2012: 215, figure V.7e, and especially Pollini 2014: 55-56, 59-60, figs. 2-5.

${ }^{104}$ From the perspective of a viewer standing on the ground the shadow would have appeared at the top of the stairs. See the following note.

${ }^{105}$ How high on the staircase or how near the western entrance of the Ara Pacis the shadow of the finial fell cannot be determined exactly because the true height of the obelisk with its finial is only a close approximation to the roughly 100 Roman feet already discussed. See Pollini 2014: 54-55.

${ }^{106}$ See Degrassi 1963: 514 for Sept. 24 in the Fasti. On this day the Arvals also sacrificed. Cf. Pollini 2012: 213-16, with fig. V.7e, where in our first published computer simulation of the Solarium/Ara Pacis complex we had already recreated this phenomenon, although the actual piercing of the doorway (with its symbolic significance) may have occurred on the second day of the biduum of Augustus' birthday instead of the first.
} 
that on these two days, birthday sacrifices would have been performed in front of the Ara Pacis at the time the shadow of the finial first approached (Sept. 23) and then approached even closer to the entrance (Sept. 24), as suggested here in figures 18 and 19.

Equally important, as the new simulations reveal, if one looked west from the customary place of sacrifice in front of the Ara Pacis' staircase, the sun's disk would have appeared to hover directly over the top of the obelisk, as recreated in figure 7 (September 23) and reported by Frischer in Appendix table 2. This phenomenon, which we observed and note here for the first time, would have also underscored the importance of Augustus' birth in connecting the obelisk with the Ara Pacis. Indeed, the alignment seen at the bottom of the staircase was repeated each day for the next five days. Each day, the best vantage point was ca. $1 \mathrm{~m}$ farther east along the axial line running up the staircase until reaching the interior of the Ara Pacis on September 26 (see Appendix table 2 for that date).

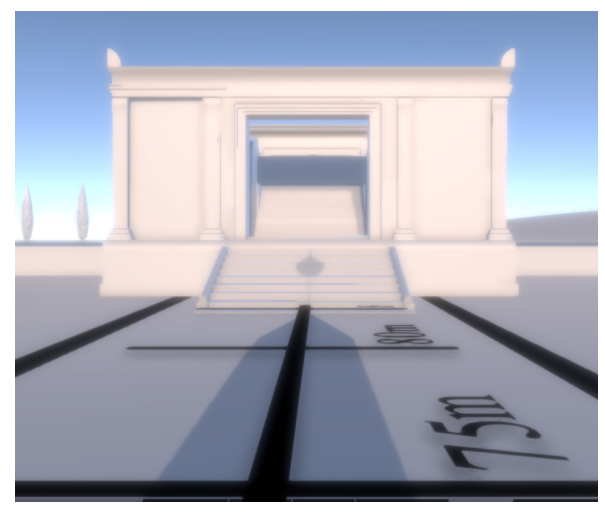

Figure 18. Frischer-Fillwalk simulation showing shadow of finial hitting front stairs of the western façade of the Ara Pacis at 16:22 CET on September 23, 9 BC. Note that Unity does not render the penumbral shadow, so the shadow of the finial has been lightened in Photoshop to suggest how it might have actually appeared.

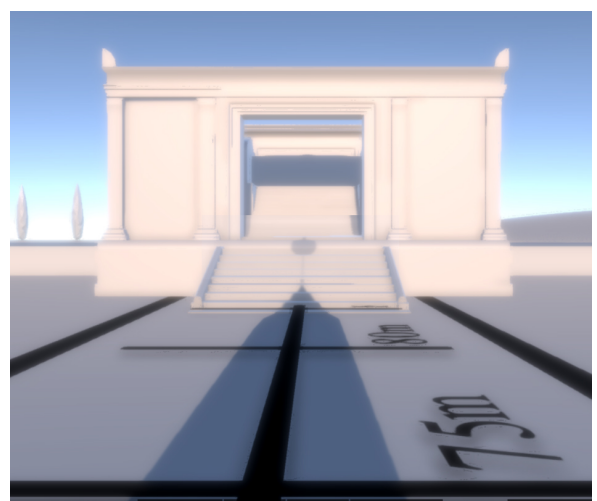

Figure 19. Frischer-Fillwalk simulation showing shadow of finial hitting front stairs of the western façade of the Ara Pacis at 16:23 CET on September 24, 9 BC. Note that Unity does not render the penumbral shadow, so the shadow of the finial has been lightened in Photoshop to suggest how it might have actually appeared.

In this context we should recall that the obelisk was an Egyptian phallic symbol stressing the life-giving force of Re, reborn into the world of man each day at Heliopolis, where his sacred obelisk-like bnbn stone was enshrined and revered [Quirke 2001:135]. In a graphic representation of Re-Harakhti ("Re-Horus of the Horizon") on the painted funerary stele of Tapéret in the Louvre (ca. 1000 BC), rays emanating from the solar disc take the form of rows of lotus blossoms. ${ }^{107}$ The ancient Egyptians regarded the lotus as the primordial symbol of creation, out of which the newly born sun was said to have arisen. The "penetration" of the stairs of the Ara Pacis and likely also its west entrance by the solar alignment, as well as by the shadow of the sphere atop the obelisk, would have great symbolic value in terms of cosmic birth or rebirth, especially since the Egyptian word for "obelisk" (tekhen) derives from the verb "to pierce," which can have sexual overtones in terms of regeneration, or rebirth, as a result of piercing or penetration. ${ }^{108}$ Moreover, the Latin word obeliscus derives from the Greek

\footnotetext{
${ }^{107}$ Louvre, inventory E 52. For an illustration, see http://www.louvre.fr/oeuvre-notices/stele-de-la-dame-taperet

${ }^{108}$ See Swetnam-Burland 2010: 139 with n. 27. See also her section 4 above.
} 
obeliskos, meaning "small spit," or "skewer," which undoubtedly also had sexual overtones, given its obviously phallic shape. Sexual overtones in the context of cosmic birth and rebirth are to be found, after all, in Augustus' own expression in his Res Gestae [13], parta victoriis pax ("peace brought forth by victories"), since the Latin perfect passive participle parta is from parīe, that is, "to bring forth" in the sense of procreation, or "to give birth to." The notion of birth and rebirth are also symbolized in the floral scroll reliefs of the Ara Pacis, as we shall see below. An implied sexual connection between the obelisk and the Ara Pacis would have highlighted Augustus' bringing to the world felicitas ("good fortune"), with its attendant fertility and prosperity, requisite for the rebirth of the Golden Age.

Augustus' birthday was also linked to Felicitas, as evidenced by the contemporary decree of the Koinon of Hellenes of Asia (Minor), noted above, and a letter of its proconsular governor Paulus Fabius Maximus,

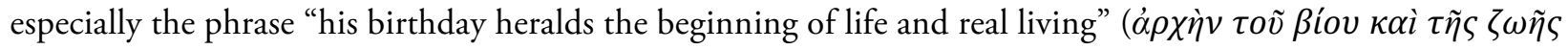

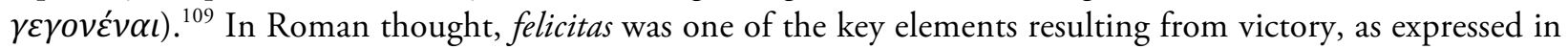
the triumphal formula, auspicio, imperio, felicitate, ductuque ("through auspices, legal authority, good fortune, and military leadership"). ${ }^{10}$ It is worth noting as well that the Temple of Felicitas in Rome was one of the six temples associated with Augustus and rededicated on his birthday [Gros 1976; Degrassi 1963: 512].

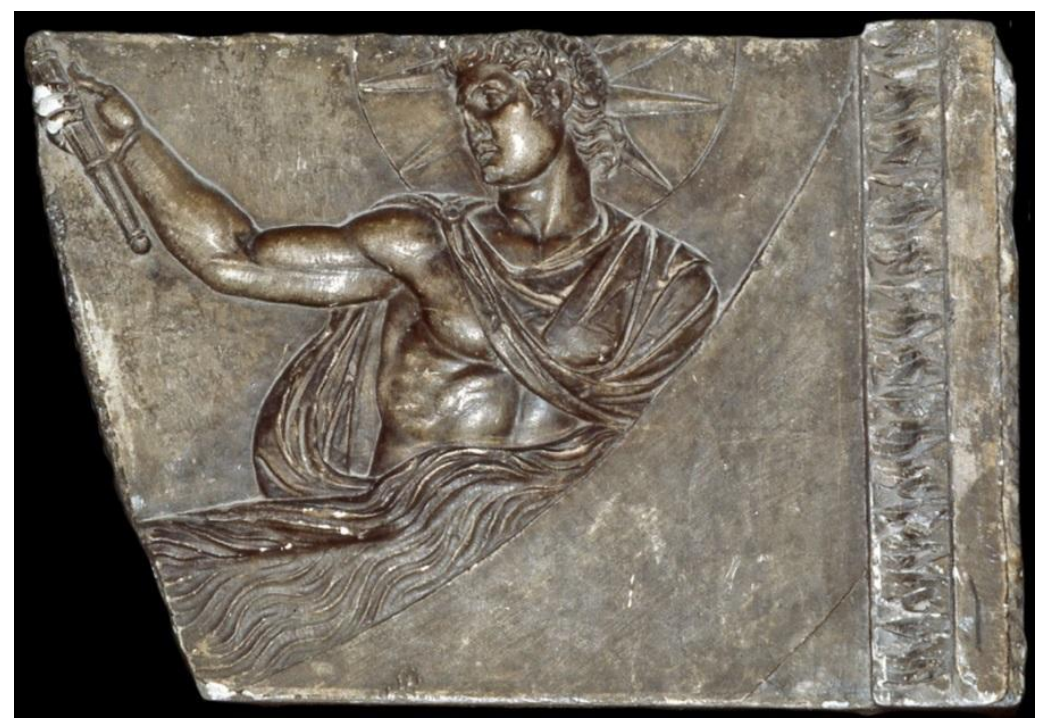

Figure 20. Fragment of a relief from Vienne showing Sol rising from the sea. Musée Lapidaire, Vienne. Source: John Pollini.

All these blessings and fruits of peace, birth, and regeneration as a result of victories were possible because Augustus was the charismatic leader chosen by the gods to govern on earth.

The messages of peace and prosperity and the prophesied return of the Golden Age under Augustus and Apollo/Sol were all given verbal and visual expression in Augustan private literature and art, as discussed by Miller below. In non-official arts, such as a relief from Vienne in southern France representing Sol rising out of

\footnotetext{
${ }^{109}$ For the preserved Greek and Latin texts with commentary, see Sherk 1969: 328-37 (no. 65); for the quotation from the Epis. Pauli Fabii Maximi 10, see 329.

${ }^{110}$ See, e.g., Livy 40.52.5. For a discussion of the meaning of the words in this Roman triumphal formula, see Versnel 1970: $356-371$.
} 
the sea (figure 20), ${ }^{111}$ the god looks somewhat like Augustus because of the strongly idealized facial features of Augustus in some of his portraits. Private or non-official sentiments such as these find close parallels in other private works of art of the Augustan Age, most notably in the Gemma Augustea. ${ }^{12}$ On this large, magnificent sardonyx cameo Augustus is presented Jupiter-like, holding a ruler's staff and augural lituus. To the left of the head of Augustus is represented a solar disc (nimbus) with the rays of the sun inscribed within it. Overlaying this is Capricorn, Augustus' natal sign [Suet. Aug. 94.12]. Together, the sun and Capricorn allude to Augustus' birth and future apotheosis, for, in Hellenistic solar theology, it was believed that divine monarchs descended to earth from the sun, king of the stars, and that after death they would return to the sun to dwell as gods in the heavens [Vell. Pat. 2.123.2; Man. Astron. 1.799-804].

Stories were also told that Augustus' father Octavius dreamt that before the birth of his son, the sun rose from the womb of Augustus' mother Atia and that Augustus himself was the product of a virgin birth, in that Apollo had come to Atia in the form of a snake (that is, a genius, or divine spirit) [Suet. Aug. 94.4]. On another occasion his father dreamt that his son appeared to him wearing the sun's radiant crown, dressed like Jupiter and with the god's insignia [Suet. Aug. 94.6]. It was also said that Augustus himself took special pride in thinking that the glance of his eyes was like the radiance of the sun [Suet. Aug. 79.2].

The co-numinous workings of Augustus' patron god Apollo-Sol are underscored in the Ara Pacis Augustae, a premier example of Augustan official art. ${ }^{113}$ Although there are no exact equivalents in Greek and Roman religion to the Egyptian sun god Re, Apollo and Sol overlap in relation to the physical sun and its life-giving powers. As a god of regeneration and of light - clearly attested in his epithets "Phoibos" and "Lykios" - Apollo is intimately associated with the personified sun, Sol (Helios). ${ }^{114}$ So closely related were Phoibos Apollo and Helios/Sol in Greek and Roman times that they were considered a numen mixtum, or mixed divine entity. Even though the two were separate divine forces, many ancients considered them to be the same [Plut. Mor. 386B, 393D, 1130A]. Their close tie was also visually attested in other forms of Augustan art. In the imperially commissioned statue of Augustus from Prima Porta, Helios/Sol is represented driving his solar chariot across the heavens at the top of Augustus' breastplate, while lower down on the left appears Apollo, playing his lyre and seated on his sacred griffin, a fabled animal long associated with the sun. ${ }^{115}$ Both gods are likewise found in close association with Augustus and his Temple of Apollo Palatinus, since the statue of Helios/Sol riding a chariot once served as the central acroterium of this temple [Prop. 2.31.11].

Specifically in connection with the notion of rebirth in nature, Helios/Sol is found represented in art rising out of an acanthus, itself a symbol of regeneration. In Hellenistic Egypt this motif was apparently adapted from

\footnotetext{
${ }^{111}$ Musée Lapidaire, Vienne: Pollini 1993a: 282, figure 85. A statue of Apollo in the library of Augustus' house on the Palatine is also said to have borne the features of Augustus. If so, it was probably set up after his death and deification; if set up by Augustus himself, it is highly unlikely that the features of the god Apollo would have been assimilated to his own, given his propriety in such matters. This would not, of course, have prevented someone from reading into the idealized facial features of the god a portrait of Augustus. For problems associated with the appearance of this statue, see Pollini 2012: 70-71; for the differences between official and nonofficial art, see Pollini 2012: 69-161.

${ }^{112}$ For the Gemma Augustea and the complexity of its visual language, see Pollini 1993a. It should also be noted that ideas expressed in this private work of art differ radically from those expressed in Augustus' official public arts after the founding of the Principate in 27 BC. See also previous note.

${ }^{113}$ For the Ara Pacis, see Pollini 2012: 204-308.

${ }^{114}$ For the many aspects of Apollo and Helios/Sol, see Pollini 2012: 271-308.

${ }^{115}$ See Pollini 1995, with further bibliography.
} 
earlier Egyptian works showing the sun god Re rising for the first time out of the primeval lotus blossom. Because of the acanthus' symbolic importance, especially in connecting Apollo and Dionysos as gods of fertility in the cycle of life, death, and regeneration, it is the dominant plant form in the floral scroll reliefs of the Ara Pacis. ${ }^{16}$ Out of its many lituoid, or lituus-like, convoluted vines grow other plant forms in a fantastic manner intended to recall the return of the Golden Age, when nature is renewed by the life-giving forces of the sun, as alluded to by the numinous presence and workings of Sol and Apollo.

Among the various animal forms on the Ara Pacis that herald this new Golden Age dawning under Augustus are the reiterated augural swans, which grace the tops of the candelabrum-like acanthus stalks. Swans were said to have attended the birth of Apollo and to have borne the god in a chariot to his oracular shrine at Delphi. On the Ara Pacis they underscore the altar's augural aspects because swans were given the gift of prophecy by Apollo [Cic. Tusc. 1.30.73], the augur god of mighty Jupiter [Verg. Aen. 4.376-378]. ${ }^{117}$ With widespread wings they are represented enframed on the Ara Pacis by another Apolline emblem, the palm, which takes the form of sickle-shaped split palmettes that resemble the wings of a bird. These split palmettes are the most frequently appearing floral forms on the Ara Pacis after the acanthus. They also are very similar to the acroteria on the corners of the Ara Pacis, as represented on the reverses of Roman coins such as the one illustrated above by Capriotti (figure 9). Palm (phoinix), too, is a symbol of victory. In Greek it is the same word ( fabled Phoinix (Lat. Phoenix), the solar bird of Arabia, or the East, where the sun rises. It also symbolizes regeneration and rebirth, as it periodically and victoriously arose from its own ashes on widespread wings to live again.

The many alignments reported above in the first part of this article also associate the gods Sol and Apollo with the Obelisk of Augustus and the Ara Pacis. As already noted, the base of the obelisk and the Ara Pacis are in near axial alignment. And, as we know from other monuments, Roman architects and urban planners were obsessed with axial alignments and with the "linear manipulation" of viewers to create specific visual and symbolic effects. ${ }^{118}$

Through these new computer simulations, it was discovered that when one stood on an extension of the axial line joining the Ara Pacis and the obelisk, there were several hundred days on which a solar alignment could be seen, whether in the early morning, when viewed from the west (Frischer's zone 1), or in the afternoon, when viewed from the east (Frischer's zone 4). Moreover, there were many days on which the ancient viewer could see the sun rising on axis behind the Ara Pacis (Frischer's zone 3), and others on which the obelisk's shadow pointed toward the direct center of the Ara Pacis, as Frischer shows in Appendix table 5. These solar alignments bring to mind Augustus' special relationship with Apollo, especially Apollo Palatinus, with his strong solar aspect, which is discussed below by Galinsky (section 9). This phenomenon also played off Augustus' birth, since another very important Temple of Apollo, that in Circo Flaminio (also known as the Temple of Apollo

\footnotetext{
${ }^{116}$ For the divine associations and meaning of acanthus, especially in connection with the Ara Pacis, see Pollini 2012: 278-96.

${ }^{117}$ For the augural aspects of the Ara Pacis' scroll reliefs, see Pollini 2012: 296-99. For the importance of augury in the figural friezes of the Ara Pacis in general, see also Pollini 2012: 204-308, et passim, and in my other essay, "Aeneas, Augury, and Dynasty and Destiny in the Ideology of Augustan Visual Culture," below, section 8.

${ }^{118}$ Cf. above n. 24. On the sight lines, linking various monuments associated with Augustus in the Campus Martius, especially the optimum viewing angle of the Mausoleum of Augustus, the Solarium's Obelisk, and the Ara Pacis Augustae, as well as their ideological significance see Pollini 2012: 210-11, figs. V.5 \& V.9, pl. XX. For Roman architects' use of sight lines and reading urban structures in context, see, in general, Favro 1996.
} 
Sosianus), was rededicated on Augustus' birthday. It was in this temple that the Senate met to deliberate on the awarding of triumphs, which soon only members of the imperial family were to be granted. ${ }^{119}$ Thus, important dates of dedication involving Augustus, his birth, his patron god Apollo, and the Roman sun god Sol were given visual form and great ideological significance in some of the greatest urban monuments in the iconosphere of Augustan Rome.

\section{AENEAS, AUGURY, AND DYNASTY AND DESTINY IN THE IDEOLOGY OF AUGUSTAN VISUAL CULTURE}

John Pollini

The concept of "peace through victory," (parta victoriis pax) emphasized by Augustus himself in his Res Gestae $[13],{ }^{120}$ found visual form in the Obelisk of Augustus (celebrating his victory over Egypt) and the Ara Pacis (heralding Augustan peace). These two monuments were axially aligned. As demonstrated by the new FrischerFillwalk Virtual Meridian Simulation of the obelisk and the Ara Pacis, after the shadow of the top of the pyramidion with its sphere-and-spike finial fell near the top of the western staircase or just into the entrance of the Ara Pacis on the biduum of September 23 (figure 18) and September 24 (figure 19), ${ }^{121}$ the shadow veered south and passed to the right of the entrance of the Ara Pacis, climbing up the right side of the precinct wall until, at ca. 16:33 CET the shadow of the finial first fell upon the figure of Aeneas in the "Aeneas panel" (figure 21) and then, moving a little further to the right, fell upon the figure of Aeneas' son Iulus at ca. 16:35. ${ }^{122}$ In this way, a visual link was established not only between Aeneas and Augustus but also with Iulus, the founder of the Julian House. The narrative of dynasty and destiny, underscored by the many augural aspects of the Ara Pacis, was thereby extended. The cycle of time from Aeneas to Augustus was now completed, and an auspicious future was to be expected to continue under the future leaders of the Julian House, who appear with Augustus in the processional friezes of the Ara Pacis Augustae.

Trojan Aeneas held a special place in the ideology of Augustus, figuring prominently both in Augustan public and private arts and in the literature of the Augustan Age, most notably in Vergil's epic poem the Aeneid. ${ }^{123}$ In official Augustan art, best exemplified in the related representational programs of the Forum of Augustus and the Ara Pacis, Aeneas played a particularly significant role in promoting the Augustan concepts of dynasty and destiny. ${ }^{124}$ Aeneas was considered the father-founder of the Roman race (gens Romana) and the archetypal ancestor of the Julian House through his son Iulus, the homonymous progenitor of the gens Iulia. Already uniquely positioned in the State as the son of Divus Iulius, Augustus, by virtue of his adoption into the Julian

\footnotetext{
${ }^{119}$ For sources, see Richardson 1992: 12-13, s.v. "Apollo, Aedes."

${ }^{120}$ For the Augustan/Roman concept of “peace,” see especially Pollini 2012: 178-190.

${ }^{121}$ See section 7 above with nn. 105 and 106.

${ }^{122}$ Some years ago, in the 1980s, I had asked Edmund Buchner if the shadow of the obelisk would have fallen on the figure of Aeneas on some day during the year. His reply was "no." However, in viewing the new simulation of the solarium with Bernard Frischer, Orietta Rossini noticed that the shadow indeed pointed toward Aeneas on the birthday of Augustus. I thank Bernard Frischer for passing on her observation to me.

${ }^{123}$ To reduce the bibliography to a minimum, I have cited where relevant my recent book (Pollini 2012), in which most of these themes have been explored at greater length and with further bibliography. See also in general Galinsky 1996.

${ }^{124}$ For the creation of dynastic narratives in Augustan art and thought, see Pollini 2012: 204-270.
} 
House, ${ }^{125}$ could claim direct descent not only from Aeneas but also from the immortal gods, in that Venus was the mother of Aeneas by his father Anchises. Augustus' birthright served, too, to validate further his status in the State as Princeps, or "First Citizen" of Rome, as well as highlight his superior auctoritas.

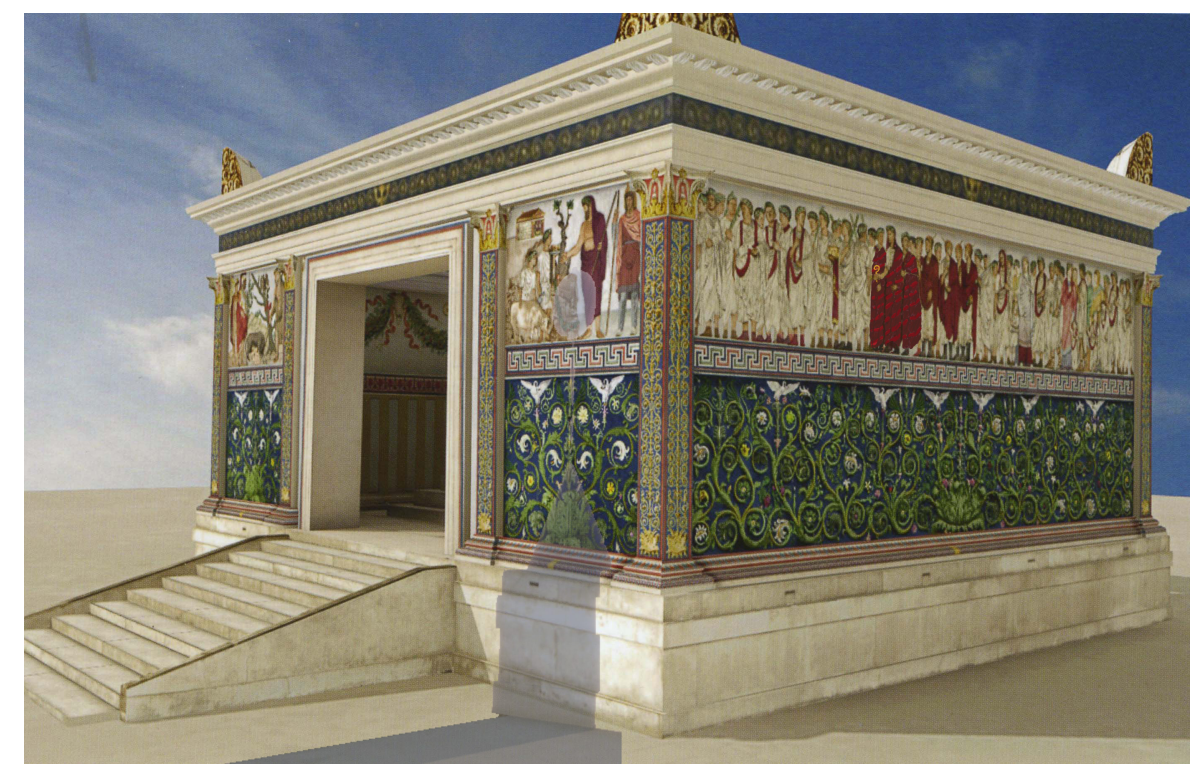

Figure 21. Shadow of Frischer-Fillwalk simulation added to Pollini's slightly altered photorealistic reconstruction of the Ara Pacis (see n. 132). Date: September 23, 9 BC at 16:33 CET. Note that to suggest the penumbral shadow of the sphere, it has been lightened in Photoshop. Source: Bernard Frischer.

One of the most important visual expressions of these ancestral and ideological connections was the over lifesize sculptural group of pius Aeneas, with his aged father Anchises (alluding to the past) on his shoulders and his small son Iulus (referencing the future) by his side, in the center of the left hemicycle of the Forum of Augustus in Rome. ${ }^{126}$ Dominating this forum was the great Temple of the Roman war-god Mars, the father of the City's founding hero Romulus, who became a god himself and was worshiped under the name Quirinus in his own temple on the Quirinal Hill. His statue, representing him in armor and shouldering a military trophy, was located in the center of the right hemicycle of the Augustan forum, as a pendant to the Aeneas group in the left hemicycle. These two state heroes, Aeneas and Romulus, were also linked through parental love, expressed in the union between Aeneas' mother Venus and Romulus' father Mars.

As Augustus had brought Mars, the god of war, within the sacred pomerium of the city, where peace was to reside, so too he "planted" the Ara Pacis Augustae in the northern Campus Martius. Many of the same underlying ideological concepts and the emphasis on dynasty and destiny, going back to Rome's founding

\footnotetext{
${ }^{125}$ For Julius Caesar in Augustan visual culture and rhetoric, see Pollini, 2012: 133-161. Koortbojian 2013 has also recently published on the divinization of Caesar and Augustus.

${ }^{126}$ This famous lost sculptural group, alluding to Aeneas' flight from Troy, was also reflected elsewhere in Rome, Italy, and the provinces in different artistic media. For this statue group and the statue of Romulus in the opposite hemicycle, as well as for the Forum Augustum itself, see Pollini 2012: 22-25, pl. II, especially with n. 58 for further bibliography.
} 
heroes Aeneas and Romulus, also find expression in the visual program of the Ara Pacis, which the Senate voted to Augustus in $13 \mathrm{BC}$ for his safe return from Rome's western provinces. This altar was set up in the northern sector of the City. Several years earlier, in 19 BC, the Senate had voted him another altar, the Ara Fortunae Reducis ("Altar of Fortuna [Patroness of] Returning"), set up in the southern sector of the City for his safe return from the eastern provinces. ${ }^{127}$ It has not been previously noted that the four cardinal points of the compass are thus symbolically referenced in these two N. and S. Augustan altars for his safe return from the W. and E. respectively. In this way, the safety of Augustus, wherever he found himself, became increasingly equated with the safety of the state itself.

The panel to the right of the entrance of the Ara Pacis depicts the archetypal ancestral hero Aeneas sacrificing over a rustic altar to his household gods, the youthful Penates, who appear in the porch of their temple. ${ }^{128}$ These gods are highly significant, since they are connected with Jupiter in augury, a point stressed by the two augural litui that appear in the pediment of their temple. Guided by the Penates and Apollo through augural signs, Aeneas had made his way to Italy, which he had learned through prophecy was the true ancestral home of the Trojans [Aen. 3.250-257]. ${ }^{129}$ To the right in the panel is a partially preserved figure wearing distinctive Trojan dress, most likely Aeneas' son Iulus, who, as noted, was regarded as the founder of the Julian House. Also represented in this panel are two attendants leading to sacrifice the famous "Sow of Lavinium," which, as was also prophesied, would lead Aeneas to the site of the future city of Lavinium. ${ }^{130}$

It is significant that Aeneas appears here no longer as youthful and beardless, attended by the child Iulus in the flight from Troy, but rather as the elderly, bearded Pater Aeneas. Having been "much buffeted on land and sea," Aeneas was destined to come to Italy, where he would "build a city [Lavinium] and bring his [household] gods to Latium, from which would spring the Latin race, the lords of Alba, and the lofty walls of Rome" (Verg. Aen. 1.1-7). Having left Troy years earlier, Iulus was now a young man (iuvenis), represented in this panel on the Ara Pacis carrying a cornel-wood spear. ${ }^{131}$ Aeneas is posed in a way that is very similar to that of Augustus in the south frieze of the Ara Pacis, though they perform different ritualistic acts. Both Aeneas and his descendant Augustus have their heads veiled and wreathed with laurel, the crown that also signifies victory. Like a visual simile, these two figures could be seen at one and the same time by those approaching the Ara Pacis on its southwest side, an optimum viewing angle (figure 21), which explains in part why the figures of Aeneas and Augustus are positioned on contiguous sides at this corner of this monumental altar. ${ }^{132}$ There is, moreover, another implied comparison and sense of emulation: in bringing peace and prosperity to the Roman world,

\footnotetext{
${ }^{127}$ Richardson 1992: 157, s.v. "Fortuna Redux, Ara."

${ }^{128}$ More than a decade ago Rehak 2001, following in part an interpretation of his mentor Lawrence Richardson, Jr., identified the stately figure not as Aeneas but as the second king of Rome, Numa Pompilius, sacrificing not to the Penates but to Jupiter and Dis. For a rebuttal of this view, see Pollini 2012: 242-247.

${ }^{129}$ That is, the original home of Dardanus, from whom the Trojans also take the name Dardani ("Dardanians").

${ }^{130}$ That this is a sow can be determined from her teats. One of her offspring might have been represented in the broken section behind her as a token figure for her brood of 30 piglets, see Pollini 2012: 221 with figure V11c.

${ }^{131}$ For the cornel-wood spears borne by Iulus and other Trojan youth: Verg. Aen. 5.557. For an older, bearded Aeneas and a grown Iulus still wearing Trojan dress to remind Romans of their Trojan origin, see Pollini 2012: 242-244, figures V.31a-c.

${ }^{132}$ For the three-quarter optimum view from the SW corner and its significance, see Pollini 2012: 239 with figure V.5 and pl. XX. Note that in my pl. XX, I altered slightly the colorized original published image in order to represent Augustus and the two figures flanking him wearing the crimson trabea of the augurs with its distinctive scarlet stripes. I have also added the augural lituus to Augustus' right hand. Figure 21 above was modified to reflect the same changes.
} 
which had been torn apart by more than a hundred years of civil wars and foreign conflicts, Augustus has even outstripped the achievement of his great ancestor Aeneas.

On the Ara Pacis the themes of foreordained peace and prosperity are also figuratively underscored in the magical scroll-reliefs, with vegetation of different seasons growing out of the dominant acanthus plant and vines, which themselves signify rebirth and regeneration of the prophesied Golden Age now dawning under Augustus. ${ }^{133}$ This fantastic floral scrollwork garden is inhabited by various creatures through whose sounds and movements the gods made their will known to man by augury. Beneath the great acanthus plant a snake slithers up to a nest of fledglings. This imagery recalls the omen foreshadowing the fate of Troy in Homer's Iliad [2.311320]. However, the Homeric portent of a doomed Troy is transformed on the Ara Pacis into a good omen: One of the fledglings flees the nest to safety, undoubtedly an oblique allusion to Aeneas' fleeing Troy and becoming the father-founder of the Roman race, the Aeneadae ("descendants of Aeneas"), who are represented directly above in the processional frieze [Pollini, 1993b: 214-15, idem. 2012: 296-298]. Without the fall of Troy, there could have been no Rome [cf. Prop. 4.1.87; Verg. Aen. 1.206]. ${ }^{134}$ The enormous, curling, lituuslike acanthus vines literally surround and bind together all of the figural reliefs of the altar's outer precinct walls. The message of the entire sculptural program of the Ara Pacis is clear: an auspicious future is to be expected under the guidance of Augustus, appearing in the exterior friezes with his family and the pious leaders of the state. With their assistance, Augustus has achieved the correct relationship with the gods, what the Romans called the pax deorum ("peace of the gods"), which was essential to the realization of the Pax Augusta, the very concept embodied in the Ara Pacis Augustae.

\section{APOLLO PALATINUS, SOL/HELIOS, AND AUGUSTUS}

Karl Galinsky

The solar and shadow alignments of the Montecitorio Obelisk with the Ara Pacis on over two hundred days of the year provide a splendid example of Augustan sophistication and make excellent sense. Buchner's hypothesis privileged a rather one-dimensional message: September 23 is the birthday of the man who was natus ad pacem. The new hypothesis proposed here that sees significance in the aggregated annually recurrent sun and shadow spectacle, by contrast, opens up wider horizons, including a closer connection with the obelisk and its dedication to Sol/Helios. In this connection it is useful to delve into the solar aspect of Augustus' tutelary deity and putative father, Apollo.

The close association between Augustus and Apollo thrived especially in the mythology of his life and in Augustan poetry [Zanker 1987: 149]. It powerfully influenced interpretations of the archaeological evidence on the Palatine, especially Carettoni's finding that the "House of Augustus" was connected to the Temple of Apollo Palatinus by a ramp [Carettoni 1983: 9 and 45 with plan 1]. That hypothesis is the Palatine equivalent

\footnotetext{
${ }^{133}$ For acanthus as a symbol of rebirth and regeneration, as well as this magical scroll-work garden with its animal life, see Pollini 2012: 271-308 with further bibliography, as well as section 7 above. For the flora represented in the scroll friezes, see also Caneva 2010.

${ }^{134}$ This was undoubtedly how the Romans could understand Troy's defeat at the hands of the Greeks and how that would be avenged. This would also explain the otherwise seemingly odd (to a modern audience) representation of Achilles killing Trojan Troilos on the breastplate of the magnificent bronze statue of Germanicus in the Archaeological Museum of Amelia: see Pollini 2017.
} 
to Buchner's, and the analogy continues as recent excavations have shown that claim to be unsubstantiated [Iacopi 2007: 7-14]. The house in question was lavish indeed, featuring two peristyles, but it was destroyed, still unfinished, for the building of the complex of the Temple of Apollo; what is shown today as Augustus' house on the upper level cannot be proved to be his [Wiseman 2014a; Wiseman 2014b; Häuber 2015: $7 \mathrm{n}$. 30].

The essential point is that neither the connecting ramp nor the "House of Augustus" are necessary for consolidating the overall picture: the Temple of Apollo was a cynosure placed next to the Augustan compound, the domus Augustana. Vowed to commemorate the hugely important victory over Sextus Pompey at Naulochus in $36 \mathrm{BC}$, its siting grew ever more extensive, leading to the teardown of the aristocratic residence under construction to make room for a Greek and a Roman library and for a large portico with statues of the Danaids. Instead of being revetted with marble, the structure was built of solid marble blocks and sent its solar reflection over a large part of the city, including the Circus Maximus; an argument has been made that its front was facing that way instead of toward the Palatine. ${ }^{135}$ Thus, there is no question but that Augustus made a statement here with a visual impact second to none.

To turn to the connections with the obelisk on the Campus Martius and the Ara Pacis, we can begin by noting that the fastigium of the temple was crowned with the chariot driven by Sol/Helios, the Sun god, ${ }^{136}$ which may have been oriented to the rising sun, the east; the representation recurs on the cuirass of the Prima Porta statue. It also looked down, as we have noted, on the Circus Maximus and the obelisk there, also imported from Heliopolis and with the identical inscription as that in the Campus: Aegypto in potestatem populi Romani redacta Soli donum dedit. Sol/Helios was, of course, identified with Apollo and a second quadriga, guided by Apollo and Diana, was placed on the arch, also on the Palatine [Pliny HN 36.26], which Augustus built in honor of his father, Octavius [Kleiner 1988]. Customarily, a statue of that honoree should have occupied the top of the arch. Here we come, of course, to a central point: the version, parallel to Zeus' fatherhood of Alexander, that Apollo was the real father of Octavian/Augustus. And Sol had yet another relevant dimension: he was the ancestor of the Latins (Helios was the father of Circe and Latinus was her son) and that may be part of the function in which he is invoked, after separate earlier invocation of Apollo, in Horace's Carmen Saeculare (alme Sol, 9), which was performed on the Palatine [Galinsky 1967]. Further, Apollo Palatinus also stood for victory, first at Naulochus and then at Actium, a dimension that was further enhanced by the proximity of the temple to the two Palatine shrines of Victoria and by the shared anniversary date with that of Venus Victrix on the Capitoline. ${ }^{137}$ Besides these multiple aspects, the significance of the temple was based on its high-profile uses, such as the repository of the Sibylline Books (transferred from the Capitoline) and frequent meetings of the senate in its libraries [Suetonius, Aug. 29.3].

In light of all this, the decision to create hundreds of annually recurring alignments of the sun, the obelisk and the Ara Pacis in the Campus Martius and nearby Campus Agrippae is extraordinarily full of meanings. One is the association of Apollo with victory, which is the precondition for pax: parta victoriis pax, as Augustus put it succinctly in Res Gestae 13. Several years before the construction of both obelisk and altar, Vergil depicted Augustus as surveying the triumphal procession, and the triumph over Egypt specifically, from in front of the

\footnotetext{
${ }^{135}$ Most recently, Zink 2012; doubted, e.g., by Claridge 2010: 142-143.

${ }^{136}$ Barchiesi 2009 ingeniously connects the Palatine Helios and the Circus Maximus with the Phaethon episode in Ovid's Metamorphoses (1.747-2.339); additional observations by Galinsky 2013: 36-38.

${ }^{137}$ Fasti Amiterni on vii id. Oct.
} 
Temple of Apollo Palatinus: sedens niveo candentis limine Phoebi [Aen. 8.720] and as affixing the gifts (dona) from the subject peoples to the temple's doors. Compare again the inscription on the obelisk: Egypt has been conquered and Augustus presents the obelisk as a donum to the Sun god, who on the Palatine is explicitly identified with Apollo. As the Frischer-Fillwalk simulations show, the shadow of the obelisk would point to the panel with the Julian ancestor, Aeneas, on September 23 (figure 21). Likewise, the impressive annually recurring solar spectacle in this part of the city recalls Palatine Sol, who was hymned, at least in part, as ancestor of the Latins in the revised celebration of the Secular Games that highlighted the increased role of the Palatine in general.

In sum, the recurrent spectacle of solar and shadow alignments reported in the beginning of this article has many dimensions - going far beyond a single date, however significant, such as September 23 — and this kind of richness of evocations and polysemous associations is quintessentially Augustan.

\section{HORACE, ODES 4.5}

John Miller

The thematic linkage between the Montecitorio Obelisk and the Ara Pacis Augustae finds parallel expression in contemporary poetry. In Odes 4.5, Horace urges Augustus to return to Rome after his long absence, since peace, prosperity, and the virtue of the nation depend upon his safety. The absence in question would be Augustus' campaigning in Gaul, whence on July 4, 13 BC he would formally enter the city accompanied by an elaborate set of ceremonies that included the inauguration of the site (the constitutio) of the Ara Pacis. ${ }^{138}$ Horace imagines Rome's plenitude and tranquility not unlike the Tellus/Pax panel on the Altar-tutus bos etenim rura perambulat, / nutrit rura Ceres almaque Faustitas, 'For the ox roams safely over the fields, and Ceres and kindly Prosperity nurture the crops' [17-18]. ${ }^{139}$ Romulus, too, figures prominently in both the ode ${ }^{140}$ and the Altar's iconography. Perhaps most striking of all in this connection, given the role of the obelisk dedicated to Sol in the Campus complex, is the powerful, salutary solar effect, that, in the opening of the poem, Horace predicts at Augustus' return [5-8]: lucem redde tuae, dux bone, patriae: / instar veris enim voltus ubi tuus / adfulsit populo, gratior it dies / et soles melius nitent, 'Restore the light, good leader, to your country: for when your face shines like spring upon the people, the day proceeds more pleasantly, and the sun shines more brightly.' Augustus, 'descended from kindly gods' (Divis orte bonis, 1), is here addressed as a quasi-sun god himself. The ode closes with the sun's movement marking day's progress as the Romans continually beseech and honor the Princeps, now directly called a god [deum, 32; tuum . . numen, 34-35]. ${ }^{141}$

\footnotetext{
${ }^{138}$ Dio 54.25 with I. Du Quesnay 1995: 135-38. For the senate's formal decision to erect the altar, the constitutio, made a feast day also for two other Augustan altars, see Aug. $R G 12.2$ and the calendars as reported in Degrassi 1963: 476; also Wissowa 1912 : 475 and Welin 1939.

${ }^{139}$ E.g., Benario 1960: 342, whose article traces parallels with the Ara Pacis throughout Odes 4; Syndikus 1973: vol. 2, 340.

140 4.5.1-2: optime Romulae / custos gentis, which triggers awareness of an Ennian passage on Romulus (Ann. 105-9 Sk.) that permeates the ode.

${ }_{141}^{4}$ 4.5.37-40: 'Longas o utinam, dux bone, ferias / praestes Hesperiae!' dicimus integro / sicco mane die, dicimus uvidi, / cum sol Oceano, a claim set up by the scene of the rustic opening condidit quisque diem (29), from which phrase emanate thoughts of the sun via its Virgilian intertexts, Ecl. 9.51-2, longos . . condere soles and G. 1.458 [Sol] referetque diem condetque relatum.
} 
From these correspondences Du Quesnay has argued that Odes 4.5 was "intended for publication and performance" at the grand celebration for Augustus' return from Gaul in July of 13 BC [Du Quesnay 1995: 182]. Not just the dramatic date, but the actual time of composition, will have antedated the emperor's return, not to mention the completion of the obelisk-Ara Pacis complex in the Campus during the years following 13 (the most commonly accepted date, too, for the publication of Odes $4^{142}$ ). But, suggests Du Quesnay, "Horace was well aware of what was being planned for the return of Augustus" [Du Quesnay 1995: 186]. While this interpretation finds support [La Rocca 1999: 155], in the absence of fuller evidence one understands the skepticism registered towards Du Quesnay's speculation that Horace's appeal for Augustus to come back was actually performed at the ceremonies for his return in 13 [Thomas 2011: $7 \mathrm{n} .13$ and 152]. It may be safer to follow Du Quesnay's alternative formulation that Odes 4.5 was “intended to evoke the carmina that formed a part of such ceremonies" [Du Quesnay 1995: 145]. Likewise, the interval of three and a half years between the adventus and constitutio of the Ara Pacis in 13 and the altar's dedication in 9, with the erection of the obelisk for Sol in between-all this should perhaps encourage us to speak in terms of Horace and the architect of the obelisk-Ara Pacis complex separately participating in the construction of Augustan ideology at a particular point in time, rather than to argue that the poet is following the lead of the architectural plan in detail. It nonetheless remains remarkable that the same nexus of ideas—return of the Princeps, sun god, peace and prosperity—recur in the two media in the same few years.

Whichever view we adopt, there emerges from the rich intertextuality of Horace's address to Augustus in solar terms [4.5.5-8] an additional correspondence that is directly relevant to the central argument of this paper. Commentators note that the image of the ruler as the sun has many precedents, and is often deployed in connection with a ruler's return. ${ }^{143}$ The cluster of solar effects here in reference to Augustus also continues the ode's engagement with Ennius' treatment of Rome longing for the deceased Romulus: 'you led us forth into the world of light' [tu produxisti nos intra luminis oras, Ann. fr. 109 Sk.]. And we have suggested that Horace's verses anticipate the obelisk dedicated to Sol in the obelisk-Ara Pacis complex. Most powerfully of all, the verses summon to mind, via poetic allusion, another spectacular Augustan monument that had captivated the imagination of Romans for more than a decade, namely the Palatine Temple of Apollo. Odes 4.5.5-8 recall another Horatian stanza addressed to the Sun god himself near the start (as here) of the Carmen Saeculare [912]: alme Sol, curru nitido diem qui / promis et celas aliusque et idem / nasceris, possis nihil urbe Roma / visere maius, 'Nourishing Sun, who in your chariot bring forth and hide the day, and are reborn new and yet the same, may you be able to see nothing greater than the city of Rome.' In both texts the sun brings day's brightness [adfulsit, dies, soles nitent; cf. Sol, nitido, diem] to Rome [patriae, populo; cf. Roma], and the two addresses are sealed with a wish or expectation marked by matching comparatives [melius; maius]. Once again, this is but part of an extensive engagement of Odes 4.5 with the Carmen Saeculare, an engagement signaled from the start (by a phrase, 4.5.1-2 Romulae... gentis, which is otherwise found only at CS 47 Romulae genti). ${ }^{144}$ In this case we

\footnotetext{
${ }_{142}$ Though there are those who argue for later dates - as late as $8 \mathrm{BC}$; for a good summary of opinions and the evidence, see Thomas 2011: 5-7.

${ }^{143}$ Du Quesnay 1995: 157 with further bibliography.

${ }^{144}$ Other connections between the two odes: fertility of the land emblematized by Ceres paired with another goddess (4.5.18 nutrit rura Ceres almaque Faustitas; CS 29-30 fertilis frugum pecorisque Tellus / spicea donet Cererem corona); the pairing of Parthians and Scythians as subdued foreign enemies, both with motifs of fear (4.5.25 quis Parthum paveat, quis gelidum Scythen; CS 54-55 Medus Albanasque timet secures, / iam Scythae responsa petunt); law guaranteeing marital virtue (4.5.21-23 nullis polluitur casta domus stupris, / mos et lex maculosum edomuit nefas, / laudantur simili prole puerperae; CS 17-20 diva, producas subolem patrumque / prosperes decreta
} 
know that a chorus did perform Horace's ode as a conspicuous part of the Saecular Games in 17 BC. And the first performance of Horace's carmen was in front of Augustus' new Temple of Apollo on the Palatine Hill, a cult with strong solar associations (see Galinsky in section 9 above). The chorus's address to Sol, himself a byform of Apollo, gestures to the site of that original performance with mention of the Sun god's chariot, which adorned the roof of Apollo's Palatine temple [Propertius 2.31.11]. ${ }^{145}$ In imaging the returning Augustus as the sun around $13 \mathrm{BC}$, therefore, Horace allusively evokes Apollo Palatinus in much the same way that the multiple solar alignments between the obelisk of Augustus and the Ara Pacis Augustae constructed in the years immediately following draw special attention to the solar cult installed by Augustus in Apollo's Palatine shrine and referenced by the dedication of the Montecitorio Obelisk in the northern Campus Martius.

\section{THE ARA PROVIDENTIAE AS SOLAR MARKER?}

Bernard Frischer

Judging by the archaeological remains, for almost three centuries Augustus' successors protected both the monuments and the axial line supporting the solar and shadow alignments reported in the first section of this paper. As is well known, in the imperial period, the Campus Martius came to be filled with dynastic monuments and temples of various kinds. It is telling that this development stopped just south what we may call the Augustan "solar park". When the Ara Pacis was at risk from the periodic flooding of the Tiber, Hadrian protected it with a retaining wall [Moretti 1948: vol. 1, 198]. When the triumphal arch of uncertain date known as the Arco di Portogallo [Torelli 1993; Liverani 2007] was erected across the Via Flaminia, it was sited just north of our axial line, which was therefore not obstructed (figure 22).

On the Apotheosis Relief decorating the Column of Antoninus Pius, the Montecitorio Obelisk is used as the attribute for the youth personifying the Campus Martius who holds it in his lap (figure 31 [Vogel 1973:3233]). This suggests that the obelisk had become by that time the identifying landmark of this entire area of the city.

There is one Tiberian monument, the Ara Providentiae, which might represent an exceptional interference with the axial line (figure 22). We shall see, however, that this was not the case. So let us next consider this monument.

super ingandis / feminis prolisque novae feraci / lege marita). Book 4 is otherwise preoccupied with the Carmen Saeculare; see, e.g., Putnam 1986: 16-20 and passim.

${ }^{145}$ Miller 2009: 247-52. Another obelisk, also dedicated by Augustus to Sol, was set up in the Circus Maximus (at about the same time as that in the Campus Martius, c. 10 BC) in a direct line of sight with Apollo's Palatine Temple. 


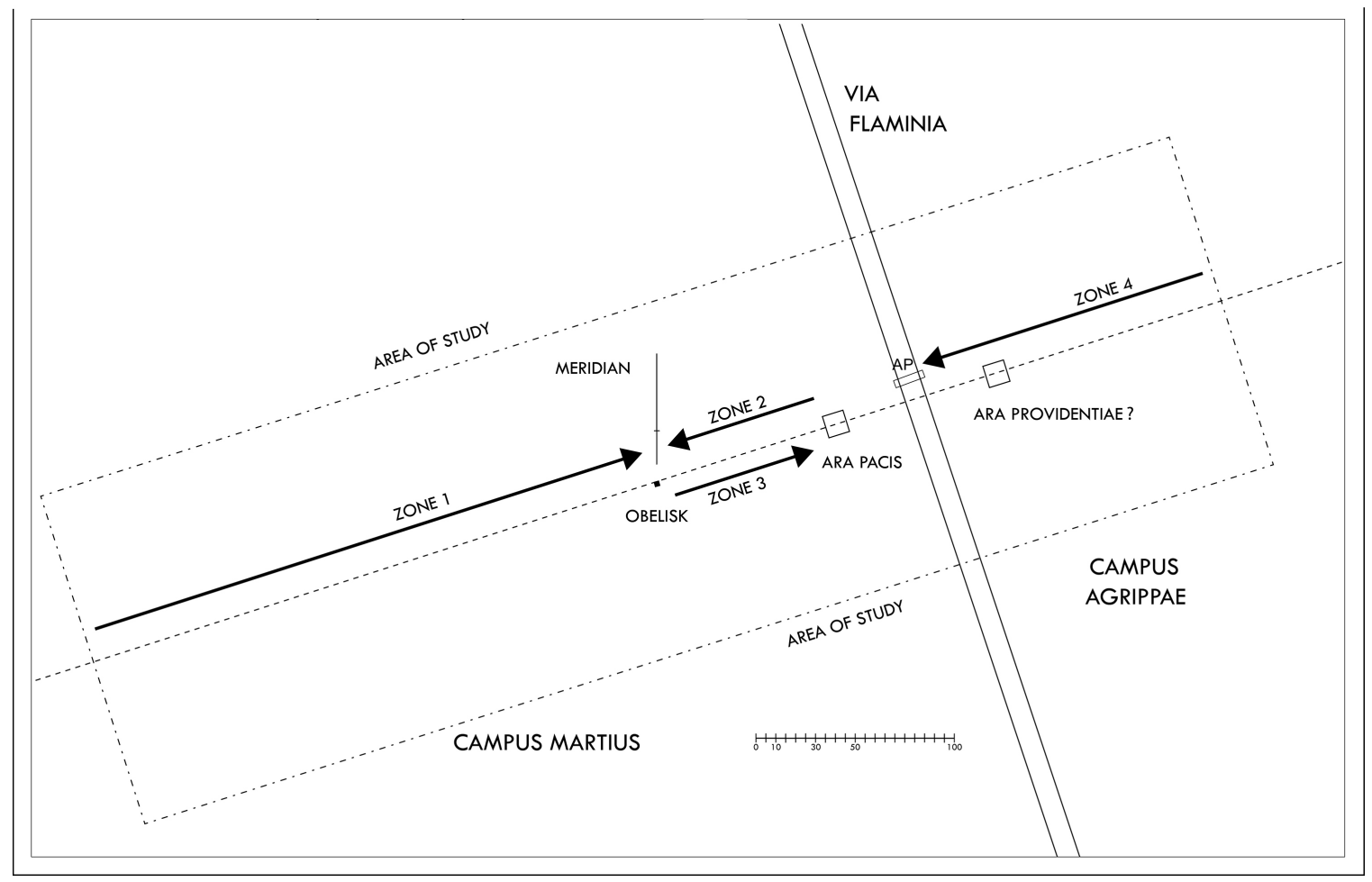

Figure 22. Map showing location of Arco di Portogallo (AP), which spans the Via Flaminia just north of the eastern extension of the axis of symmetry of the Ara Pacis. Also seen along the axial line to the east of the Via Flaminia is the hypothetical position of the Ara Providentiae.

On the basis of good numismatic evidence, ${ }^{146}$ the Ara Providentiae is known to have resembled the Ara Pacis (figure 23). It is also known to have been erected in the Campus Agrippae. ${ }^{147}$ Charlesworth argued in 1936 that the providentia honored at the altar was Augustus' foresight in choosing Tiberius to be his successor [Charlesworth 1936; Béranger 1975]. As for date, a post quem of 13 AD is provided by Augustus' latest revision of the Res Gestae, where the monument is not mentioned. The latest possible ante quem of $20 \mathrm{AD}$ is provided by the s.c. de Cn. Pisone patre, where at lines 82-84 Piso's name is ordered erased from a statue of Germanicus near the Ara Providentiae. ${ }^{148}$ It is likely that the ante quem is several years earlier. ${ }^{149}$ Once erected, the altar is recorded to have been used by the Arval Brethren on several occasions which happen to be memorialized in the preserved $a c t a$. Under Caligula in $38 \mathrm{AD}$, there was a sacrifice at the altar on June 26, probably to commemorate Augustus' adoption of Tiberius on that date in 4 AD [Scheid and Broise 1980: 234].

\footnotetext{
${ }^{146}$ See Scheid and Broise 1980: 232 n. 26.

${ }^{147}$ Cf. Scheid et al. 1998: 30 (C. César [no 11-16]), line 56: in Campo Agrippae ad aram Providentiae Augustae.

${ }^{148}$ For the text see Eck et al. 1996, and see pp. 197-202 for commentary on the passage in question; Potter and Damon 1999.

${ }^{149}$ On this matter see the discussion by Fishwick 2010: 252. Fishwick's attempt to date the Ara Providentiae to before the death of Augustus, despite Augustus' silence in the Res Gestae, is unconvincing; see ibid., 252, and cf. Lott 2014-15: 149.
} 

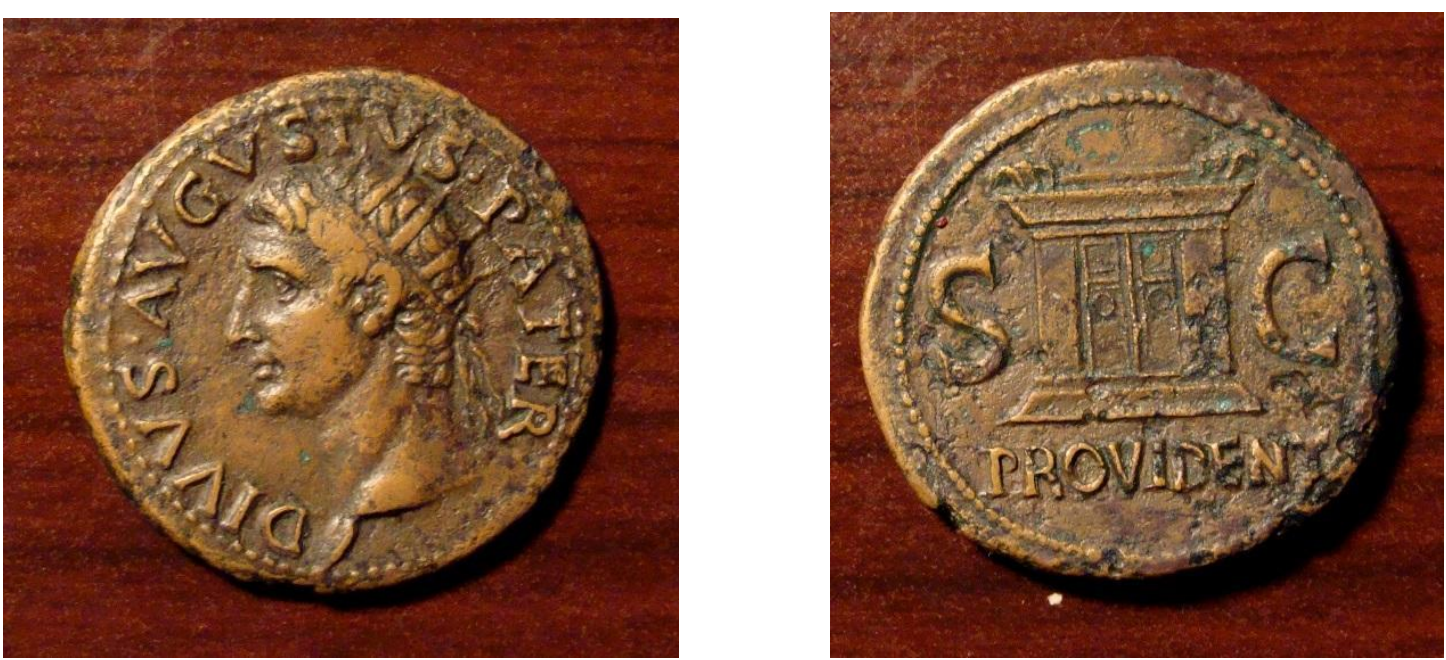

Figure 23. AE As; Rome Mint; 29mm/11g. Left: Obverse. DIVVS AVGVSTVS PATER; Radiate bust of Augustus. Right: Reverse. PROVIDENT. S. C. Facade of Ara Providentiae Augusti (Sear 1789, RIC I 81). Photograph courtesy of Philip Grathwol.

A second mention of a sacrifice at the altar, also under Caligula, occurs in a fragment of the acta that is lacking information about the date. The immediately following text includes the date of October 24/26, making it likely that the sacrifice at the Ara Providentiae occurred on the occasion of the Augustalia, held from October 3 to 12 each year. ${ }^{150}$ This festival celebrated Augustus' return from the East in 19 BC, the occasion on which the Ara Fortunae Reducis near the Porta Capena was dedicated. After Augustus' death, the festival, held on just one day in his lifetime (October 12), was extended from October 3 to 12 and included public games [Wissowa 1912: 263; Degrassi 1963: 516 (Oct. 3-12), 519 (Oct. 12); Lebek 1988].

The location of the monument in the Campus Agrippae is not known, but Scheid and Broise wrote in 1980 that "it is tempting to imagine that the architects structured the space in such a way that the view of someone looking at the altar of Providence toward the west, for example when he participated in the annual sacrifice, encompassed at the same time the Mausoleum of Augustus and the Ara Pacis: the architectural perspectives would thus also confer a meaning to the sacrifice, the meaning intended by the imperial entourage, to grasp that the Augustan Peace was guaranteed by the wide-ranging 'providence' of divus Augustus and the providential virtues of his heirs. Urbanism and ideology thus cohere in this enormous garden, this sanctuary as big as a city quarter, in order to legitimate not only the choice of a successor and his action, but also the entire Julio-Claudian dynasty through a clearly sacred conjunction between the mausoleum, the Ara Pacis, and the Ara Providentiae, between Augustus, the ruling dynasty, and peace." ${ }^{151}$ Several years later, Coarelli converted these words into the more concise topographical proposal of considering the Ara Providentiae to be a pendant

\footnotetext{
${ }^{150}$ See Scheid 1998: 38, note on fgh, 1. 9-16.

${ }^{151}$ Scheid and Broise 1980: 235-236 (translation by B. Frischer).
} 
of the Ara Pacis with the same dimensions, orientation, and distance from the Via Flaminia (figure 22). ${ }^{152}$ The position indicated on Coarelli's map has been adopted by later scholars. ${ }^{153}$

If, for the sake of argument, one accepts the Scheid-Broise-Coarelli hypothesis about the altar's location (even if-and this should be stressed—-the present author is skeptical about the hypothesis because in his experience archaeological reality seldom corresponds so neatly to our modern hypotheses), then the line of axial symmetry running east from the Ara Pacis bisects the Ara Providentiae. It is therefore important to gauge how this hypothetical location, if accepted, would impact the solar alignments we have been discussing. To do so, we created a version of the Stellarium simulation in which the Ara Providentiae corresponds to the Ara Pacis in size and orientation and is positioned an equal distance off the Via Flaminia to the east.

Moving the date forward to $\mathrm{AD} 17$, our finding was that placing the altar here caused minimal or no disruption to the pattern of solar alignments detected earlier, even though the altar would be directly on the axial line. The following table shows the dates, times, and positions of solar alignment as revealed by two variant reconstructions of the Ara Providentiae: the first, in which the interior exactly resembles that of the Ara Pacis, with a sacrificial table raised off the interior floor; the second, in which the interior was simply paved, and the sacrificial table, if present, was not raised. In both versions, the alignments on October 10 occur when the observer stood in front of the west entrance, and by October 14, the observer was well beyond the altar to the east. In table 1, the observer would have stood on the interior stairs before the sacrificial table on October 12 and 13 . In table 2 , the observer would have already been outside the altar to the east by October 12 . The following table gives the relevant data:

Table 1: Variant with raised sacrificial table

\begin{tabular}{|c|c|c|}
\hline Date (AD 17) & Time (UTC) & Coordinates \\
\hline Oct. 11 & $15: 45: 22$ & $172.27 \mathrm{~m}, 71.36 \mathrm{~m}, 0.23 \mathrm{~m}$ \\
\hline Oct.12 & $15: 46: 48$ & $173.52 \mathrm{~m}, 71.74 \mathrm{~m}, 1.24 \mathrm{~m}$ \\
\hline Oct. 13 & $15: 48: 17$ & $176.11 \mathrm{~m}, 72.52 \mathrm{~m}, 3.15 \mathrm{~m}$ \\
\hline
\end{tabular}

Table 2: Variant without raised sacrificial table

\begin{tabular}{|l|l|l|}
\hline Date (AD 17) & Time (UTC) & Coordinates \\
\hline Oct. 11 & $15: 45: 22$ & $172.27 \mathrm{~m}, 71.36 \mathrm{~m}, 0.23 \mathrm{~m}$ \\
\hline Oct. 12 & $15: 46: 48$ & $183.24 \mathrm{~m}, 74.80 \mathrm{~m}, 0.22 \mathrm{~m}$ \\
\hline Oct. 13 & $15: 48: 17$ & $204.84 \mathrm{~m}, 81.38 \mathrm{~m}, 0.22 \mathrm{~m}$ \\
\hline
\end{tabular}

The only less than perfect alignments are those of October 12 and October 13. In variant 1 on October 12 the view of an exact centering of the finial with the solar disk is blocked by the superstructure of the altar over the west doorway. However, at the time and position specified on the table, there is a good enough alignment for practical purposes. Similarly, in variant 2 on October 13, a precise centering of finial and solar disk is blocked by the superstructure over the east doorway, but the alignment seen from this position is adequate.

These results mean that not only would an Ara Providentiae located in this position not have interfered with the Augustan scheme, but it could also lend credence to the Scheid-Broise-Coarelli theory. Zone 4 is rich in October alignments. If the Ara Providentiae really was located where the theory stipulates, then it occupies a

\footnotetext{
${ }^{152}$ Coarelli 1983: 41-42, and see also the map on p. 43. Scheid 1998: 35 (on c, 1. 54-57) cites this passage with approval.

${ }^{153}$ Coarelli's view is accepted by Torelli 1999a: 166. For the same arrangement see the map of Bodel 1999: 54 . The theory is repeated in Coarelli 2007: 235.
} 
spot when the October alignments coincide with the Augustalia (October 5-12; [Lebek 1988: 62]). Some might be tempted to see this as not coincidental but evidence in favor of the Scheid-Broise-Coarelli theory.

In this connection we may note that, as Bergmann pointed out, the biggest Tiberian coin issue was the as showing the Ara Providentia on the reverse and a radiate head of Augustus on the obverse. (figure 23; Bergmann 1998: 106-107) The iconography of the radiate crown clearly links Augustus - the first emperor shown this way-with Jupiter and Apollo-Sol, as Bergmann notes [Bergmann 1998: 104]. Here, again, the s.c. de Cn. Pisone patre and its mention of a statue of Germanicus near the Ara Providentiae is relevant. Since the inscription tells us the statue was erected by the sodales Augustales [see Hemelrijk 2007: 319], it ought to have been part of a portrait group that included Augustus [Rose 1997; Boschung 2002]. One might imagine a radiate Augustus standing somewhere near the Ara Providentiae [see Pollini 2012: 355-357, fig. VII.39a-b]. Such a statue would have provided a suitable prop for the celebration here of the Augustalia by prestigious priesthoods such as the Arvals and Augustales in precisely the days when the zone 4 solar alignments are occurring nearby.

The nexus of associations seen on the as may have their topographical correlative in the Ara Providentia set on the axial line of solar alignments just in the section coincident with the climactic days of the annual festival held to honor Augustus. Assuming the Scheid-Broise-Coarelli theory is correct (and we again stress here that we do not claim that it is), then we will have to do with a solar marker analogous to the first marker at the western staircase to the Ara Pacis-yet another way the two altars will resemble each other. The fate of this monument is unknown; interestingly, one scholar has speculated that it was incorporated into Aurelian's Temple of the Sun, the subject of the next section [Torelli 1999a: 166], while another scholar has suggested that a fragmentary Julio-Claudian relief preserved in the Museo Gregoriano Profano of the Musei Vaticani may once have decorated the inner altar of the Ara Providentiae [Pollini 2012: 324, fig. VII.15].

\section{AURELIAN'S TEMPLE OF SOL INVICTUS IN ROME}

Michele R. Salzman

Aurelian dedicated a temple to Sol Invictus in Rome in 274 as a sort of ex voto for his victories over Zenobia in 272 and over Tetricius in $274 .{ }^{154}$ Considering how much has been written about the location of this temple, it is surprising how little consideration has been given to why Aurelian built it where he did. The topographical associations of this temple will be the focus of this contribution, after a brief overview of the evidence. Of particular relevance to this article is the association of Aurelian's temple to the solar monuments of the Augustan age. But as we shall see, modern topographers concur that it can be identified with the temple to the Sun in the Campus Agrippae in a position across the axial line of solar alignments in zone 4 identified above by Frischer. ${ }^{155}$

Though the temple was described as "magnificentissimum" and "the precinct was endowed with wealthy gifts," 156 nothing of it remains today. Scholars argued for some time about its exact location and its

\footnotetext{
${ }^{154}$ HA. Aurelian 39.2 and 39.4; Eutropius 9.15.1 repeat the notion of the temple being “most magnificient." See Hijmans 2010: 388 , for bibliography for the dedication year of 274.

${ }^{155}$ For possible locations of the temple, see Liverani 2006-2007.

${ }^{156}$ Aurelius Victor 35.7: His tot tantisque prospere gestis fanum Romae Soli magnificum constituit donariis ornans opulentis.
} 
orientation. ${ }^{157}$ Most scholars today, however, accept the textual evidence and agree that the temple ascribed to Aurelian in honor of Sol should be located in Region VII of the city, as it is so described by the fourth-century Origo Gentis, which lists this emperor's temple, together with a set of castra in the campus Agrippae. ${ }^{158}$ The fourth century Regionary Catalogues similarly lists a Templum Solis and castra in this Region. ${ }^{159}$ Based on this evidence, the sixteenth century drawings by Palladio that are identified with this temple on the site of San Silvestro in Capite have led most scholars to posit that the temple had an east-west orientation. ${ }^{160}$ This would be in accord with the orientation recommended by Vitruvius for temples in general, and it would seem particularly apt for a temple to Sol to have an east-west orientation. ${ }^{161}$

The sixteenth-century drawings also indicate that this temple included two buildings under whose porticoes, as noted in our fourth-century source, wine was stored; Aurelian is said to have begun the state distribution of wine at reduced prices as a right of the plebs Romana. ${ }^{162}$ An inscription $(C I L 6.1785+31931)$ records the transport of barrels from the area of the Ciconiae to the Temple; this inscription was discovered near San Silvestro in Capite and provides some additional evidence that the temple with its porticoes was the location for wine distribution.

The nature of the temple precinct-which Zosimus (1.61) mentions included statues of Belos and Heliosremains open to speculation. Since no one has identified the remains of its cella or foundations, some posited that the porticoes were in an enclosed sacred space without a temple proper, and that the Renaissance drawings are more fantasy than actual. ${ }^{163}$ Moreover, Aurelius Victor mentions that Aurelius built a fanum (or, sacred precinct) without mentioning a temple. ${ }^{164}$ The mid-fourth century Origo Gentis, Regionary Catalogues, and the author of the Historia Augusta call the construction a templum, indicating a sacred precinct and perhaps a temple. ${ }^{165}$ If this sacred precinct acquired a proper temple, it is possible-but not at all certain — that eight porphyry columns reported by an eighth-century source to have been given in ca. 536 to the church of Hagia Sophia in Constantinople were from the Aurelianic temple proper, or from one of the porticoes in the precinct. ${ }^{166}$

\footnotetext{
${ }^{157}$ For more about the dispute on its location between Lanciani, who wanted to locate the temple on the Quirinal, and Hülsen, see Calzini Gysens and Coarelli 1999: 331-332. For the finds from the temple and recent literature see Capanna 2013: $486-487$.

${ }_{158}$ Origo Gentis in the Chronogr. A. $354148 \mathrm{M}$ : templum Solis et castra in campo Agrippae dedicavit [Aurelian].

${ }^{159}$ Regionary Catalogues in Valentini and Zucchetti 1940: 111 and 219.

${ }^{160}$ Torelli 1992; Calzini-Gysens and Coarelli 1999: 331-332. See too Liverani 2006-7: 302-305; Hijmans 2010: 385-390.

${ }^{161}$ Vitruvius 10.4.5.1.

${ }^{162}$ Hist. Aug. Aureliani 25: templum Solis fundavit; 48.4: in porticibus templi Solis fiscalia vina ponuntur. Latin text here and later from LCL, ed. D. Magie. For discussion, see Calzini-Gysens and Coarelli 1999: 331-332 and Liverani 2006-7: 302-305.

${ }^{163}$ Hijmans 2010: 388 suggests that there was no actual temple building within the enclosed space of the porticoes, but this does not square well with the testimony of Zosimus. Hijmans 2010: 388 is following earlier scholars who agree that "the round peripteros, drawn by Palladio in the larger enclosure, is a Renaissance fantasy."

${ }_{164}$ Aurelius Victor 35.7.

${ }^{165}$ Hist. Aug. Aurelian. 25: sacerdotia composuit, Templum Solis fundavit et pontifices roboravit; Chronogr. A. 354148 M: templum Solis et castra in campo Agrippae dedicavit [Aurelian].

${ }^{166}$ Codrinus reports that the columns belonged to a widow, Marcia, who gave them away; see Codrinus, De antiquit. Const. 4 P 65 (p. 131-2 Bekker, Corpus Script. Hist. Byz.) and more recently, Ps.-Codrinus, Narratio de structura templi S. Sophiae, Antiquitates Constantinopolitane 4. 185 ed. Prenger 1901, I, 75-76. However, this is a text of the eighth century, so not entirely reliable. On the other hand, we do have other instances of private donations of public monuments from Rome from the fifth or sixth centuries; see Liverani 2014.
} 
Most important for our argument, Aurelian chose to build his ex voto monument to Sol in the Campus Agrippae. We do not know what was on the spot prior to this construction, but the area certainly had strong associations with Augustus and Sol for centuries. After his victory over Cleopatra and Antony, Augustus had brought an obelisk from Egypt as a gift to Sol and placed it in the Campus Martius to be used as a gnomonic device. Though the device was no longer functioning by the time of Aurelian, the obelisk and the inscription would have remained visible to visitors in late antiquity. The third-century visitor to Rome could see that Augustus had given the obelisk to commemorate his conquest of Egypt and as a "gift to Sol." ${ }^{167}$ So the memory of Augustus's victory in the East, the restoration of peace to the Empire through military success as recalled by the Ara Pacis, and his subsequent offering to Sol in the Campus Martius set a powerful precedent for Aurelian. ${ }^{168}$ Just as Augustus sought to associate his victory over the Egyptian queen Cleopatra with the divine power of his defeated enemy, so, too, Aurelian could associate his victory over the defeated Eastern queen Zenobia with the divine power of the Palmyrene Sol. Military victory had been necessary to establish peace in the time of Augustus; likewise, Aurelian's conquests would bring peace back to Rome.

Although Sol had been worshipped in Rome before this date, Aurelian's reforms of the cult signaled that his particular version of solar worship would be distinctive. First, it is worth noting that several of the sources comment on the immense size of the precinct. Second, in a clear effort to elevate this cult above others, Aurelian instituted a new college of priests, pontifices (Dei) Solis, second in rank to the pontifices maiores, who now were known as pontifices Deae Vestae. ${ }^{169}$ Third, Aurelian celebrated his cult with new sorts of public games, such as the agon Solis. ${ }^{170}$ Moreover, as I have argued elsewhere, his new cult to Sol Invictus incorporated elaborate games with some thirty races in the circus on December $25^{\text {th }}$, a few days after the winter solstice. The association of this day's games with Aurelian requires further explanation, since the Codex-Calendar of 354 and an oration of Julian provide the earliest textual evidence that December $25^{\text {th }}$ was celebrated in honor of Sol in Rome. Moreover, I would argue, as have many earlier scholars, that December $25^{\text {th }}$ was most likely the dedication day of this emperor's new temple in the city. ${ }^{171}$

The common assumption found in many publications is that the winter solstice was celebrated on December $25^{\text {th }}$, and hence it was this reason that prompted Aurelian to dedicate his temple with games to Sol Invictus on this day. Under Christian rulers, this holiday was interpreted as the celebration of the birthday of the Son of God, with metaphors, in later fourth and fifth century texts, about the light of Christ's justice abounding. ${ }^{172}$ This narrative is not quite correct, for the winter solstice in the 270s fell several days earlier. Moreover, prior to Aurelian there is no evidence that the winter solstice or December $25^{\text {th }}$ was celebrated in honor of Sol in Rome. As I have argued more fully elsewhere, the only other source for December $25^{\text {th }}$ as important for solar worshippers is an astronomical calendar from Egypt attributed to Antiochus of Athens, a document that most probably dates to the third or fourth century. ${ }^{173}$ On December $25^{\text {th }}$ in Antiochus's calendar we read: "birthday

\footnotetext{
${ }^{167}$ CIL 6. 702=ILS 91: .../Aegypto in potestatem/ populi Romani redacta/Soli donum dedit .

${ }^{168}$ Frischer and Fillwalk 2014; and Albéri Auber 2014.

${ }^{169}$ Hist. Aug. Aurelian. 25: sacerdotia composuit, Templum Solis fundavit et pontifices roboravit.

${ }^{170}$ Origo Gentis in the Chronogr. A. 354148 M: agonem Solis instituit.

${ }^{171}$ For the Calendar of 354, see Salzman 1990: 127-128; and Julian Or. 11.4.42-43. Though there is no absolute evidence that the December $25^{\text {th }}$ day noted as the Natalis Invicti was the dedication day of Aurelian's temple, it seems most likely since only recent imperial holidays were honored with so many circus games in the mid-fourth century. For an alternative view, see Hijmans 2010. ${ }^{172}$ This is the common view, as noted by Hijmans 2010: 389 .

${ }^{173}$ I presented my ideas in a paper in 2015 and in print, Salzman 2017.
} 
of the sun; light increases." ${ }^{174}$ This Egyptian calendar may, however, reflect a wider Eastern understanding about the sun; only a few days after the solstice can one be certain of the sun's rising, and so celebrate it accordingly. This notion was common in Egypt, and presumably also in the East, as Julian in Antioch expressed it later. This widespread idea may explain why Aurelian chose to honor Sol Invictus on December $25^{\text {th }}$.

I am not the first scholar to propose that December $25^{\text {th }}$ was the celebration of the dedication of Aurelian's temple to Sol Invictus in the Campus Martius, but the arguments for this dedication have not given sufficient weight to the Egyptian calendar of Antiochus that reflects earlier Egyptian worship of the sun. ${ }^{175}$ Moreover, there has been little appreciation of the topographical associations for Aurelian's choice of a location for his temple. As earlier sections of this article have demonstrated, Augustus's association of military victory in the East with Sol led to the location of the Montecitorio Obelisk in association with the Ara Pacis. Augustus set a powerful precedent for Aurelian, who, similarly, was seeking to legitimate his rule through military victory. Moreover, Aurelian was, like Augustus, planning on founding a new dynasty. The conscious echoes of Augustus also emerge on Aurelian's coins, another way in which Aurelian could tie his rule to that of the originator of the imperial system. ${ }^{176}$ Finally, as an emperor seeking to unite the East and the West in a time of peace, Aurelian, like Augustus, was aware of the universal appeal of solar cults across the empire.

If I am correct, the celebration of the dedication of Aurelian's temple on December $25^{\text {th }}$ in the Campus Agrippae area follows Augustan precedent by linking Aurelian's victory and solar worship with Augustus's victory and the Egyptian Sol. What better place to build his temple to Sol than in an area already associated with Augustus's recurrent solar spectacle. Aurelian's precinct probably straddled the axial line of the solar alignments in Frischer's zone 4. In any event, it stood within the viewshed of the Montecitorio Obelisk, whose duplicate inscriptions recorded its celebration of imperial victory and its dedication to the Sun god.

\section{SUMMARY AND CONCLUSION}

Bernard Frischer

\subsection{Summary}

In this collection of essays we reported on new research utilizing computer simulations of the Augustan northern Campus Martius and adjacent Campus Agrippae that showed a recurrent annual cycle of alignments between the sun, the obelisk, and the Ara Pacis. At a minimum alignments of sun or shadow took place 238 days each year from February 25 to October 21. The details of exact time and place change slightly in the second and third years of the leap-year cycle. Even if the height of the obelisk is increased to $30.7 \mathrm{~m}$, and the position of the obelisk is adjusted accordingly, essentially the same series of alignments is attested, and, indeed, the number of dates increases to 251 from February 17 to October 28. Two different visualization engines were used to run the simulations, each of which used a different method to calculate the solar ephemerides. The results of the simulations were essentially the same, and this duplication of our observations added confidence to the validity of our observations.

\footnotetext{
${ }^{174}$ Lehoux 2007: 343. CF. Wallrach 2001: 176 and n. 9.

${ }^{175}$ For a full discussion of these arguments with bibliography, see Hijmans 2003 and Wallrach 2001. See now Salzman, 2017.

176 Watson 1999: 201-202.
} 
Capriotti interpreted these findings in the light of Hellenistic Egypt. The central role played by the Sun god suggested a relationship between the architectural design of the Ara Pacis and the Egyptian "horned altar" found near temple tombs in several locations, including the temple of Egyptian deities at Delos and in the area of the east temple at Karnak where-as in the northern Campus Martius_-there was also a "unique obelisk." A function of this altar type may well have been to support burnt sacrifices offered to various gods with the goal of destroying the enemies of the Sun god and of the king. The design of the Ara Pacis reminds us of the hieroglyph akhet. The zone 3 solar alignments of the rising sun on axis behind the Ara Pacis is an apt illustration of Capriotti's interpretation.

Swetnam-Burland shifted the focus to the Montecitorio Obelisk, whose original Egyptian context is explained to provide the requisite background for understanding its adaptation in the Augustan Campus Martius. Erected by Psametik II, it honored the Sun god Re-Harakhti, the incarnation of the Sun god of the dawn. The praises recorded to him on the obelisk attribute to him the power to grant life, happiness, and power to the king. Hence, in its original Egyptian context the obelisk celebrated the divine rights of the king while honoring the Sun god who bestowed those rights on him. She next discussed how the Romans understood the obelisk, starting with the observation that they would not have had access to-or probably interest in—an exact, "scholarly" translation of its inscriptions. Yet Pliny's discussion of obelisks shows that educated, elite Romans had a basic understanding of their meaning and import. He also attests that the Romans well understand the solar symbolism of obelisks. Another relevant source is Hermapion's translation of the Flaminian Obelisk, which is preserved in Ammianus Marcellinus. Hermapion may well have lived not in the time of Ammianus but in the first century AD. At any rate, he continually invokes Apollo as the child of the Sun god and sometimes fuses him with king Ramestes. Apollo is the recipient of the sun's benefits and the intermediary who makes them available to mankind through military victory and benefactions. Augustus was clearly familiar with the solar significance of the Montecitorio Obelisk, which he dedicates to Sol. This divinity was the subject of special cult honors in Augustan Rome and was assimilated to Apollo.

Murray then picked up the theme of the ideology of kingship in Hellenistic Egypt, discussing the fusion of Apollo and Horus in relation to astronomical alignments. In Apollonius of Rhodes, Apollo is the "Lord appearing at dawn", a concept very possibly also attested on an inscription from the precinct of the Serapaeum and in ritual texts on walls of the Temple of Horus at Edfu. Another aspect of Apollo stressed by the Ptolemaic kings is his association with buildings, especially sacred buildings first reflecting astronomical alignments. Augustus, too, linked his legitimacy to rule to his special relationship with Apollo, notably in the Palatine temple, which emphasized Apollo's solar aspect. This solar Apollo derives from Hellenistic Egyptian and, ultimately, earlier fifth-century precedents. Indeed, in his capacity as king of Egypt, Augustus amplified the importance of Apollo-Horus by keeping only the Horus name and jettisoning the four other traditional regal names. Murray concludes that the conjunction of the Sun, the obelisk, and the Ara Pacis expressed Augustus' Horus name "in monumental terms."

Häuber also closely connected the Ara Pacis and the Montecitorio Obelisk to the Egyptian ideology of kingship. Her point of departure was different from Murray's: the close connection between the Sun god Re and the pharaoh, which established Maat. She interpreted the Ara Pacis as the Augustan monument par excellence expressive of this ideology of rulership. Augustus' appropriation of the radiate image and symbol of the cornucopia from his Ptolemaic predecessors also reflects the concept of Augustus as a ruler favored by the Sun god who can therefore bestow peace and prosperity on his people. 
Pollini and Cipolla focused on the Ara Pacis as an expression of the Augustan ideology of peace through victory, a message reinforced by the Montecitorio Obelisk, whose dedication was explicitly motivated by the fact that Egypt had come into the possession of the Roman people. Important in understanding the Ara Pacis is its association with imperial birthdays. It was dedicated on Livia's fiftieth birthday. One of the many solar alignments reported earlier in this article occurred on Augustus' birthday, as seen by someone standing in the architecturally strongly marked spot of the western entrance of the Ara Pacis.

A study of the shadow alignments reported here shows that they moved up the staircase and pierced, or penetrated, the altar in an almost sexual way-another allusion to fertility and birth. This phallic association of the obelisk and its shadow suggested the message that Augustus brought felicitas with its attendant fertility and prosperity to the Roman world, themes richly featured in the iconography of the Ara Pacis. Behind this iconography is the god Apollo, a Sol figure whose life-giving light and warmth is the basis of felicitas. Beyond the Ara Pacis, the iconography of Sol and Apollo bulks large in Augustan art, sometimes with the emperor himself assimilated to images of the gods in the non-official arts of the Augustan age.

Pollini next interpreted an observation made by Orietta Rossini when Bernard Frischer showed her the Virtual Meridian: on Augustus' birthday (September 23), after the shadow of the obelisk fails to reach the western entrance of the Ara Pacis, it strikes the area to the right of the doorway, pointing at the Aeneas relief. According to Pollini, this may be intentional: the shadow suggests the strong tie between Augustus and Aeneas, the ancestor of the Julian family into which Augustus was adopted by Julius Caesar.

Galinsky treated the most important Augustan monument dedicated to Apollo, the great Palatine temple. This temple has strong solar associations. In a manner reminiscent of the Ptolemaic ideology of kingship, Augustus, too, associated Apollo with military victory, which is the precondition for the peace celebrated by the Ara Pacis.

Miller explored how the association of Augustus with the Sun and the solar god Apollo were developed in several poems of Horace which reflect Augustan ideology. In Odes 4.5, Horace urges Augustus to return to Rome since the city's security and prosperity depend on his presence. At the beginning of the poem, Augustus is fused with the sun when the poet writes, "Restore the light, good leader, to your country: for when your face shines like spring upon the people, the day proceeds more pleasantly, and the sun shines more brightly" (Odes 4.5.5-8). It is remarkable that the nexus of Augustus' return from war, the Sun god, peace and prosperity occur in a relatively short period of time in Horace's poem, the iconography of the Ara Pacis, and the dedicatory inscription on the obelisk. Relevant in this connection is the fact that near the beginning of Horace's earlier poem, the Carmen Saeculare, the Sun god is addressed as the deity bringing dawn and evening and looking down on Rome in its unparalleled greatness. We know that a chorus first performed the poem in $17 \mathrm{BC}$ in front of the Temple of Apollo Palatinus.

Frischer then addressed a hypothetical obstruction of the axial line to the east: the possibility, mooted by several recent scholars, that the Tiberian Ara Providentiae, often considered a twin of the Ara Pacis in design and dimensions, was erected ca. $30 \mathrm{~m}$ to the east of the Via Flaminia on an extension of the axis of the Ara Pacis. While stressing that this siting is purely speculative (and that he is skeptical that the speculation is correct), he suggested that, even if true, the Ara Providentiae would not so much have disturbed the solar spectacles along the axial line as added a new solar marker for a relevant annual festival, the Augustalia.

Finally, Salzman looked at the later topography of the Campus Agrippae in the general area where the Ara Providentiae is presumed to have stood, across the Via Flaminia from the Ara Pacis. She suggested that it is not 
a mere coincidence that the third-century emperor Aurelian situated his Temple of the Sun in this area with its many earlier solar alignments and associations. Aurelian exploited the area's existing solar associations and by building his solar shrine here-probably stretched across a section of the axial line in zone 4-he also explicitly linked his rule with that of Augustus, whose reputation and prestige were undiminished with the passage of time.

\subsection{Conclusion}

At this point two key issues ought to be addressed: (1) Why should we imagine that the solar alignments reported and interpreted here were intentional? (2) Assuming the answer to the first question is affirmative, then was each of the alignments meant to be seen and by whom?

Regarding the first question, there are clearly three possibilities: (1) the solar alignments were the inevitable, if accidental, result of placing any two structures in fairly near proximity to each other anywhere on the ground at this latitude; (2) they were the inevitable result of intentionally creating one, key alignment (e.g., for the sake of argument, those around Augustus' birthday in zone 2); and (3) they were all intentional.

In grappling with this issue we note that, first of all, the gnomonic instrument attests that solar alignment was part and parcel of the overall Augustan design. It is true that we began by claiming that the design and operational details of the timepiece were irrelevant to our theme in this paper. That remains true. However, the instrument should be now recalled as proof positive that the Augustan designers were thinking in conscious terms of coordinating the sun, the obelisk, and the meridian. The device was based on harmonizing the (apparently) moving sun and the stable obelisk in order to render the same time (local noon) each day in the same longitude (the meridian line). The focus of the viewer's attention, if the effort was successful, was the gnomon's shadow projected onto a crosshatch (regula) on the long meridian line. The meridian has rightly been called a scientific instrument. Seeing it in operation appealed to the rational intellect more than to the viewer's emotions. The purpose of the instrument was, moreover, purely practical.

The axial system we have been studying reflects the opposite possibility: coordinating the (apparently) moving sun and the stable obelisk to create a vision of the sun, the obelisk and/or the Ara Pacis seen from different latitudes-longitudes at different times of the day on various days of the year. The effort, if successful, would not have conveyed scientific information about date and time, but would instead have both appealed to the viewer's aesthetic sensibility and aroused his feeling of religious awe. The purpose was not practical—telling time—but symbolic: creating a recurrent hierophany of the Sun god. It implicitly transmitted a message about the nature of the emperor who commissioned the complex and at the same time evoked reverential awe for the Sun god to whom the emperor dedicated the obelisk, itself a well-understood solar token.

Achieving the scientific purpose required that the obelisk be sited near the meridian line with its perpendicular metal crosshatches. To effect the emotional response it was desirable to pair it with some evocative monument such as the Ara Pacis, which used symbolism to produce a range of positive aesthetic and emotional responses. In other words, had we only been interested in alignments of the sun's disk over the obelisk without reference to the Ara Pacis, then the objection could justly have been made that once you had the obelisk and meridian, you willy-nilly got the obelisk's solar alignments, so that attributing intentionality to such phenomena is purely arbitrary. Indeed, without the Ara Pacis and its dual role of providing an axial line on which the observer had to stand as well as a sight for targeting the top of the obelisk and the obelisk's shadow, there would have been many more-indeed, millions of-potential solar alignments associated with the obelisk. 
So the presence of the Ara Pacis and its tethering role are crucial, and its decisive role in the Augustan project is revealed by the telltale sign that the obelisk is aligned not to the meridian and cardinal points, as one might well have expected, ${ }^{177}$ but to the altar 90 meters away, which is itself oriented to the Via Flaminia. At a minimum, this is telling us that the designers encouraged the ancient viewer to see the two monuments in close relationship.

Why did the designers establish such a close, visual connection between the Ara Pacis and the obelisk? At this point, the siting of each monument should be considered, a question not yet treated in previous scholarship about these monuments. If purely a visual relationship was desired, the designers could have put the two monuments somewhat closer or farther apart than they actually were. Why are they sited ca. $90 \mathrm{~m}$ apart?

The first point we can make is that the shadow alignments were not determining this choice. If they were, then the $90-\mathrm{m}$ interval would represent the maximum possible number of shadow alignments available for monuments designed in this way and standing at these particular geographical coordinates. In actual fact, however, the closer the obelisk moves toward the Ara Pacis, the more shadow alignments one gets. For example, we made two simulations in Stellarium which supported experiments in which the obelisk was moved $50 \mathrm{~m}$ east and west of its actual position. When the obelisk was $50 \mathrm{~m}$ closer to the Ara Pacis, there was a gain of seven pairs of dates before $2 / 25-10 / 21$ and nineteen pairs after 3/21 - 9/27 for a net gain of 52 dates of alignment. Contrariwise, in the version of Stellarium in which the obelisk was moved $50 \mathrm{~m}$ west of its actual position, we observed a gain of 14 dates before the pair 2/25 - 10/21, but a loss of 26 dates from 3/9 - 10/9 to 3/21 - 9/27. We conclude that 90 - $\mathrm{m}$ interval between the monuments was chosen for a reason other than maximizing the number of shadow alignments.

So let us look at the solar alignments and see what they tell us. Again, we can compare our findings with an obelisk hypothetically moved either $50 \mathrm{~m}$ farther west or $50 \mathrm{~m}$ farther east.

The maximum number of solar alignments we found occurs in zones 2 and 3. Both zones have the same spatially terminal date, the summer solstice. By "spatially terminal," we mean that at this point along the line, the viewer must step back in the opposite direction to get the dates of alignment after the summer solstice. Now, each starting point is on the two nodes-3/19 - 9/27 inside the Ara Pacis and 4/30-8/18 at the obelisk. Had the two monuments been placed closer together, then their visual alignment might have been still clearer, but the starting pairs of alignment dates in each zone would have been lost. For example, we made a version of the Stellarium simulation with the obelisk set $50 \mathrm{~m}$ to the east of its actual position (i.e., ca $40 \mathrm{~m}$ from the Ara Pacis). This simulation shows that the dates in the west entrance (i.e., Zone 2) of the Ara Pacis become 4/14 $9 / 2$. Hence we lose all the alignments from $4 / 3$ to $4 / 15$ and from $9 / 3$ to $9 / 27$. Standing at the obelisk and looking east at sunrise we find that the first dates of alignment in the reduced Zone 3 is no longer 4/30 $-8 / 18$ but 5/10 - 8/8. So, moving the obelisk $50 \mathrm{~m}$ closer to the Ara Pacis results in a loss of 46 days of alignment in Zone 2 and 18 days in Zone 3. This net loss of 54 dates of solar alignments more than cancels out the gain of 52 dates of shadow alignment.

Moving the obelisk $50 \mathrm{~m}$ to the west of its actual position adds eight pairs of alignments from $3 / 11-10 / 5$ to $3 / 18-9 / 28$ in Zone 2. The first three of these pairs we already have at the beginning of Zone 4, so they are

\footnotetext{
${ }^{177}$ And as was certainly expected by the $18 \mathrm{C}$ British surveyor, James Stuart, who found the obelisk's rotation so odd that he felt obliged to check the accuracy of his compass when it revealed the obelisk's 15 degree counterclockwise rotation; see Bandini $1750: 72$.
} 
not an real addition as compared to what we actually find. So putting the obelisk $50 \mathrm{~m}$ to the west nets five new pairs of dates. In Zone 3, we gain one pair of dates at the very beginning of the sequence, which would start with $4 / 29-8 / 19$ instead of $4 / 30-8 / 18$. This total gain of twelve days in new solar alignments exactly balances the loss of twelve days of shadow alignments. Thus moving the obelisk $50 \mathrm{~m}$ to the west results no change to the overall number of shadow and solar alignments, but with the additional $50 \mathrm{~m}$ of distance between the altar and obelisk, the purely visual relationship between them would have been attenuated.

And this brings us back to our point of departure: the siting of the Ara Pacis and the Montecitorio Obelisk does not appear to be the result of chance but of an application of the "Goldilocks" principle: ${ }^{178}$ with a separation of $90 \mathrm{~m}$, the number of shadow and solar alignments is maximized while at the same time the visual relationship between the two monuments remains strong.

One additional point that emerges from the foregoing analysis: the distillation of a solar marker from the general cloud of shadow and solar alignments along the axial line through our four zones. We have seen that the more the obelisk is moved closer to the Ara Pacis, the greater the loss of total alignments. We have also seen that moving the obelisk farther away would have provided no net gain in alignments while costing something in terms of the visual connection of the altar and the obelisk. There would have been another price to pay as well: if one moves the obelisk to the west, then one also shifts to the west all the dates of alignment we actually found. But this would mean that the specific alignment flagged by Pollini-September $23^{\text {rd }}$ at the foot of the western staircase to the Ara Pacis—would also be lost. To see this alignment, you would now have to stand $1 \mathrm{~m}$ to the west of the staircase for every $1 \mathrm{~m}$ the obelisk was moved to the west. ${ }^{179}$ This formula works in the opposite direction as well: every meter the obelisk is moved east from its current position toward the Ara Pacis causes the September 23 alignment to move one meter farther east along the axial line.

The front of the western staircase fulfills our minimum conditions of a solar marker. If the alignment of September 23 is moved to the east or west along the axial line, this becomes just another date which, however marked in Augustan culture and on its calendar, was not physically marked on the ground. ${ }^{180}$ It would thus be arbitrary to attribute any particular significance to it as opposed to the myriad other dates on the Roman religious calendar for which we also found alignments (see Appendix table 6 for the dates). The fact that the monuments are sited the way they are suggests that Pollini-Cipolla may be correct to see the foot of the western staircase as a solar/shadow marker. ${ }^{181}$ If so, then our research suggests that Buchner's most important point, while wrong in detail, was correct in general: the Ara Pacis and the Montecitorio Obelisk are connected in relation to Augustus' birthday. But now the connection is made by both a solar and a shadow alignment, and those alignments do not occur in the middle of the Ara Pacis and they have nothing to do with the (hypothetical)

\footnotetext{
${ }^{178}$ For a definition of the "just right," Goldilocks principle, see https://en.wikipedia.org/wiki/Goldilocks_principle

${ }^{179}$ The Stellarium coordinates are: $37.38 \mathrm{~m}, 29.80 \mathrm{~m},-1.50 \mathrm{~m}$.

${ }^{180}$ Note that the obelisk could have moved ca. 10 m east and still left the alignment on September 23 in a potentially marked position somewhere from the foot of the west staircase to the west entrance of the Ara Pacis. For about the next 20 m of eastward movement of the obelisk, the view is blocked of the top of the obelisk, hence no alignments would have been visible in this area. And, once we move more than ca. $16 \mathrm{~m}$ eastward from the foot of the west staircase, we are no longer inside the Ara Pacis and thus have lost our potential marker in any case.

${ }^{181}$ We may note here that the Stellarium simulation with an obelisk of $30.7 \mathrm{~m}$ shifted $1 \mathrm{~m}$ south still gives us an alignment on September 23 at the bottom of the western staircase.
} 
equinoctial line, of which Buchner made so much. So we might grant that Buchner was partially right for the wrong reason.

This suggests that at a minimum, the second of our three theoretical possibilities regarding intentionality is operative. What about the third possibility-that all the alignments were intended, not just the one on September 23? This is more difficult to demonstrate because, clearly, granting that the monuments were sited $90 \mathrm{~m}$ apart in order to create the solar alignments in the period from September 23 to September 27, the other alignments followed automatically: it was not within human power to turn the sun on and off or to vary its regular (apparent) movements through the sky.

On the other hand, if we take our point of departure from Augustus' stated intention of bringing the obelisk to Rome as a gift to the Sun god, then self-celebration by the donor is too narrow a goal. We saw in our experiments moving the obelisk closer to and farther from the Ara Pacis that this did not significantly reduce the number of shadow and solar alignments. This means that Augustus could have had it both ways: creating a specific small group of alignments associated with his birthday, while at the same time honoring the Sun god with a much larger series of solar and shadow alignments stretching through much of the year. Nothing prevented Augustus from pursuing both goals. All he needed to do was site the two monuments at the right distance to set up the birthday alignments at a marked place, and create a strong visual relationship between the two monuments. This he accomplished through a shared orientation, by siting the obelisk almost exactly on the axis of the symmetry of the altar, and by guaranteeing an unobstructed view for hundreds of meters in either direction along the axial line. We know that all these conditions were, in fact, fulfilled, not only during the reign of Augustus but for several centuries thereafter. ${ }^{182}$ Here we may draw special attention to the Arco di Portogallo, the siting of which to the east of the Ara Pacis might well suggest that the zone 4 solar alignments were considered something to be respected. Zone 4, of course, has nothing to do with Augustus' birthday and adds a new point favor of the importance of the motivation to honor the Sun god.

If we want to push further beyond the Augustan phase, we can note that each of the later known or possible enhancements to this part of the city plays on the solar theme, as if something more than a handful of solar alignments aimed at honoring one individual was occurring here. As we have seen, the first possible addition was Tiberius' erection of the Ara Providentiae at a spot along the axial line where appropriate October alignments would occur on the Augustalia, known to have been celebrated, in part, before this altar. The secondcentury conversion of the former meridian into a basin-reflecting, at once, the sky and the obelisk-has recently been interpreted in a way compatible with the solar theme we have been developing [Heslin forthcoming]. The climactic enhancement was doubtless reached with Aurelian's Temple of the Sun in the Campus Agrippae, whose exact design and location are not known. Although topographers have proposed different footprints for the sanctuary, there is general agreement in situating it in positions that would have put it athwart our axial line.

To sum up, we have some grounds for suspecting that the third possibility was operative: the logic of the layout of the monuments made it possible to honor both the dedicator and the dedicatee. The evidence that the former was done is the Ara Pacis, which stands at the right spot to mark the emperor's birthday. The evidence that the latter was also a goal is the orientation and siting of the obelisk and Ara Pacis as well as the lack of obstructions

\footnotetext{
${ }^{182}$ An observation made earlier at Moretti 1948: 115.
} 
along the entire length of the axis of symmetry of the Ara Pacis for at least $300 \mathrm{~m}$ in either direction of the obelisk.

We therefore conclude that the solar program created in the area of the Campus Martius and Campus Agrippae exemplifies the tertium quid theorized at the beginning of this article, in which hundreds of solar-shadow alignments throughout the year are combined with one or more marked alignments on a given date. Since the reason for the former is to honor Sol in the most appropriate way imaginable-using his very dedication as the "magic wand" to bring forth his hierophany-it is quite compatible with the point of the latter, which is to present Augustus as both the devotee of Sol and the man born as "the sun who arose from Atia's womb" (Suet., Augustus 94.4).

This last point explains on an ideological level why the intention to honor the dedicatee alone would have been too narrow. In discussing the Montecitorio obelisk, Herklotz, ${ }^{183}$ citing Grandet 1986, drew our attention to the same passage in Suetonius, which we now quote in full:

I have read the following story in the books of Asclepias of Mendes. When Atia had come in the middle of the night to the solemn service of Apollo, she ...fell asleep, while the rest of the matrons also slept. On a sudden a serpent glided up to her and shortly went away. When she awoke, she purified herself, as if after making love with her husband.... In the tenth month after that Augustus was born and was therefore regarded as the son of Apollo. Atia too, before she gave him birth, dreamed that her vitals were borne up to the stars and spread over the whole extent of land and sea, while Octavius dreamed that the sun rose from Atia's womb. [Suetonius, Augustus, 94.4]

She also noted that a similar story is reported by Cassius Dio 45.1.2-3:

For Caesar, being childless and basing great hopes upon him [i.e., Augustus], loved and cherished him, intending to leave him as successor to his name, authority, and sovereignty. He was influenced largely by Atia's emphatic declaration that the youth had been engendered by Apollo; for while sleeping once in his temple, she said, she thought she had intercourse with a serpent, and it was this that caused her at the end of the allotted time to bear a son. Before he came to the light of day she saw in a dream her entrails lifted to the heavens and spreading out over all the earth; and the same night Octavius thought that the sun rose from her womb.

In both passages we have the story that a serpent impregnated Augustus' mother, Atia, in a sanctuary of Apollo and that she and her husband, Octavius, had dreams associating the soon-to-be born Augustus with the heavens and the sun. Both versions agree in calling Apollo the father of Augustus. Herklotz follows Grandet in seeing an Egyptian background behind the story of Atia's vision that her womb spread over the sky: the sky goddess Nut devours the Sun every evening so that he can be reborn the next morning. ${ }^{184}$ The pharaoh was the offspring of his goddess mother and his divine father, the Sun god. As such, "the pharaoh is the earthly incarnation of the Sun god," ${ }^{185}$ just as Apollo-Sol is the father of Augustus. At Rome, this parentage bolstered Augustus' claim to power; in the Greek world, it associated him with another divinely-engendered figure, Alexander the Great;

\footnotetext{
${ }^{183}$ Herklotz 2007: 209.

${ }^{184}$ Herklotz 2007: 219; Grandet 1986: 370-373.

${ }^{185}$ Herklotz 2007: 219.
} 
and in Egypt, it was consistent with Augustus' role as pharaoh. ${ }^{186}$ Herklotz recalls the Egyptian ideology of kingship in which the pharaoh is "s3 Re," the "son of Re," something exemplified, as Swetnam-Burland noted above, on the Montecitorio Obelisk itself. Moreover, this concept could also be behind the architectural design of the Ara Pacis, if Capriotti's suggestion is accepted that it derives from the horned altar associated in Egypt with the rebirth of the sun and the related daily battle it fights at dawn against its enemies and the enemies of the pharaoh. So if the alignments at the Ara Pacis evoke Augustus' birth, then those along the entire axis can be related to the sun's (re)birth. Both involve epic battles against enemies: Re is only reborn each morning after fighting victoriously over his enemies during the night. The Ara Pacis was built to celebrate Augustus' victories from one end of the empire to the other. In pursuing the double goal of celebrating himself and the Sun god, Augustus was not simply sharing an honor with another; he was simultaneously emphasizing the strong bond that existed between himself and his putative father.

Of course, as Capriotti Vittozzi noted, the Romans did not simply translate elements of Egyptian culture in their pure, original form to Rome but always adapted them to their own needs and traditions. ${ }^{187}$ Our study presents a case in point. To mention only the major differences: apart from the unique obelisk of Thutmose II and IV in the Amun-Re-Harakhty Temple at Karnak East (called a "striking exception" by Bell), ${ }^{188}$ the Egyptians generally used obelisks in pairs, not as singletons. ${ }^{189}$ We have no evidence that they created axes of solar alignment with obelisks in or around their sanctuaries. Indeed, without the leap year in their 365-day calendar, they could not do this, since whatever date-specific alignment they chose would soon cease to be valid as time advanced through the 1,460 astronomical years of the Sothic cycle.

Hence, one implication of the Augustan program is connected, at a deep level, with the gnomonic device: like the operation of the latter, the solar spectacle of the obelisk-altar alignment demonstrated the advantage of the Roman calendar: it was harmonized with the ephemeris of the sun such that it was possible to set up an alignment of the sun over the obelisk that would recur at more or less the same time and place each yearsomething the Egyptians were never able to achieve, even if the Fifth Dynasty determinative (figure 3) suggests that they might have occasionally wished to do so. Although we know that the gnomonic device ceased to render accurate time by ca. AD 40 (almost certainly because, as Stuart discovered in the eighteenth century, the obelisk had subsided by $5 \mathrm{~cm}$ to the southwest), the computer simulations show that this slight shift-however fatal to the scientific instrument-would not have affected the sun's alignment with the Ara Pacis and Montecitorio Obelisk (see Appendix tables 1D-4D). Augustus' sun and shadow show was not stopped by any physical defect or astronomical miscalculation. This is why the third-century emperor Aurelian found it worthwile to enhance the spectacle with the addition of an impressive solar sanctuary athwart the axial line.

This brings us to the second question raised at the beginning of this section: was each of the solar alignments meant to be seen, and by whom? The only answer we can honestly give is that we simply do not know. All we

\footnotetext{
${ }^{186}$ Herklotz 2007: 219-220.

${ }^{187}$ See also the survey of recent scholarship on this issue in Versluys 2015.

${ }^{188}$ Bell 2002: 23.

${ }^{189}$ McKenzie traces this Roman habit to the single obelisk erected by Ptolemy II Philadelphus in the Arsinoeion; see McKenzie 2007: 33. The determinative of the sun atop the obelisk discussed above suggests that the Egyptians would have liked to achieve what Augustus did, but because their calendar lacked the leap year, they were unable to coordinate the solar ephemeris with a fixed time and date. Cf. Schäfer 1929: 723: "Die religiöse Vorstellung, dass der Gott auf dem Obelisken ruhe, war in den Schreibern so lebendig, dass sie wieder einmal, wie so oft, eine in ihrer bildhaften Schrift gegebene Möglichkeit zur Symbolik hübsch benutzt haben.”
} 
can say is that an ex silentio argument against our interpretation based on the lack of an eyewitness account in the surviving ancient literary record would be unjustified. The literary notices of the monuments in question are too scanty to build a case along the lines, "surely if Frischer et al. were correct, then Roman author X would have mentioned these alignments." It is worth noting, in the connection, that such an ex silentio argument was rarely, if ever, raised against the theory of Edmund Buchner, which our new interpretation would replace.

This brings us to the matter of how, in conclusion, we would update Buchner's view that the obelisk-altar relationship implicitly propagated the message that Augustus was natus ad pacem. If a new slogan is sought, one might emend Buchner's text to read: "Augustus was natus ad pacem because of his devotion to Sol-Apollo." That is, Augustus' ability to bring Rome victory in war and prosperity in time of peace was made possible by the divine origin and sanction of his rule as well as by his own pietas. On an objective, scientific level, this meant that it was Augustus who was the one to correctly implement Julius Caesar's calendar. On a subjective, religious level, it meant that he felt a special relationship with Apollo and Sol, insofar as they were separable deities in his mind. The solar alignments discussed in this paper provided unmistakable evidence of the emperor's piety toward Sol-Apollo. In terms of power, the obelisk-altar project showed that the emperor had the massive human and material resources required to bring an obelisk from Egypt to Rome and to have it erected with great precision both to serve the needs of a great scientific instrument, the gnomonic device, and to express his deep religious devotion through the recurrent sun and shadow spectacle he created in the Campus Martius and nearby Campus Agrippae.

In short, our new interpretation views the relationship of the Ara Pacis and Montecitorio Obelisk as an expression in the language of monuments and astronomy of the still-extant words inscribed on two sides of the plinth of the obelisk [CIL $6.702=I L S$ 91]:

IMP CAESAR DIVI F

AVGVSTVS

PONTIFEX MAXIMVS

IMP $\overline{\mathrm{XII}} \operatorname{COS} \overline{\mathrm{XI}}$ TRIB POT $\overline{\mathrm{XIV}}$

AEGYPTO IN POTESTATEM

POPVLI ROMANI REDACTA

SOLI DONVM DEDIT
Emperor Caesar Augustus,

son of the deity,

chief priest,

serving with imperial power 12 times, as consul

11 times, and with tribunician power 14 times,

because Egypt had been brought under the

power of the Roman people,

gave this as a gift to the sun god. 


\title{
14. APPENDIX I - TABLES
}

\author{
Bernard Frischer
}

Appendix Table 1: Report on solar alignments west of obelisk

Zone: 1

Software used: Stellarium

3d plug-ins: 3d Sceneries (a) Meridian Augusti revised (=29.6 m obelisk); (b) 30.7m Obelisk (used in stress tests)

Settings: View-Markings-Projection: Perspective.

Height of gnomon: $29.6 \mathrm{~m}$ (100 Roman feet)

Year investigated: 9 BC (“- 8 ” on Stellarium's clock)

Time: UTC

Alignment: obelisk's finial centered on sun's disk

Year: $9 \mathrm{BC}^{190}$

Observer: Bernard Frischer Date: 8/12/2015

Note 1: Sun is never high enough in sky for an alignment until the observer is at least 80 meters west of the obelisk. In practice, as the table shows, there is no solar alignment closer than ca. 98 meters to the obelisk.

Note 2: Observations arbitrarily stopped at 196 meters west of obelisk. In the modern city, this corresponds to the intersection of the modern Via di Pallacorda and the Via Metastasio. There is no evidence of imperial building in the zone studied, which appears to have retained its nature as a public park by (cf. Strabo 5.3.8) long after the reign of Augustus. If one wanted, the study of solar alignments could be extended farther to the west until the Tiber is reached more than $1 \mathrm{~km}$ away from the obelisk along the line running from the middle of the Ara Pacis and the middle of the obelisk. ${ }^{191}$

Note 3: On the following table, the measurements in meters are approximate and are offered to give users a quick idea of where to move Stellarium's camera. The Grid Coordinates are exact.

Note 4: On the table, Date-1 and Time-1 give the times when the centers of the finial and solar disk closely coincide. Date-2 and Time2 give the equivalent dates later in the year. Usually, the centers do not coincide as closely on these latter dates. The slight difference is detectable at the small FOVs used for analytical purposes but not at the more realistic FOV of $90^{\circ}$ which approximates what the ancient observer will have seen.

Note 5: In the published version of the simulation, the user may go directly to the grid coordinates indicated on the table. To do so, open the Configuration Window (the wrench icon on the left side of the screen). Select Plugins and click "configure" in the bottom left. In the 3d Scenery window, click on "Load/save viewpoints." A list of stored viewpoints is displayed. Click on the date as per Date1 on the tale below. Stellarium moves the camera to the appropriate grid coordinates. Stellarium does not, however, change the date or

\footnotetext{
${ }^{190}$ In using the year $9 \mathrm{BC}$, we are aware of the fact that in that year, the calendar had not yet been re-synched to the leap year. That would not happen until AD 4. But the Romans were already aware of the problem and were addressing it. So the obelisk-Ara Pacis alignment will have been based on the corrected Julian calendar. Here and in the other tables, we have therefore "proleptically corrected" the solar data for 9 BC (see: https://en.wikipedia.org/wiki/Proleptic_Julian_calendar).

${ }^{191}$ In the area not studied, one interesting zone is the modern Piazza S. Apollinare where, according to Palmer 1990: 15-17, the games celebrating Augustus' return in 13 and $7 \mathrm{BC}$ were held. The games of 13 were votive games given by Tiberius on the occasion of Augustus' return from Spain, Gaul, and Germany. They are thus closely connected with the festivities that saw the Senate's vow of the Ara Pacis. The line running from the center of the Ara Pacis to the obelisk passes through this general area. The distance to the piazza from the obelisk is ca. $435 \mathrm{~m}$. A solar alignment with the obelisk is seen in this area on August 13 (Feriae Jovi). Presumably, Tiberius' games took place during the Ludi Romani (sacred to Jupiter) in September, not during the festival on August 13. The Tiber sets a limit of late April=late August to possible alignments that could be viewed in the Campus Martius.
} 
time. Do this by click on the clock icon on the left side of the screen. Set the date to 132 (AD); and key in the appropriate month, day, hour, minute, and second, as per the table below.

Note 6: On Table B we present the observations for three randomly selected dates listed on Table A. Only one date in a date-pair was studied.

Note 7: Since at present it is not possible to lock the camera onto a fixed path in Stellarium, the data that follows below are only approximately correct. We estimate they are accurate to $\pm 10.00 \mathrm{~m}$ and \pm 30 minutes. Since the point of the table is to show that, without doubt, there are many solar alignments in the area of the Ara Pacis and obelisk, we consider this degree of accuracy to be acceptable.

Appendix Table 1A: Dates and times of alignment (29.6 m obelisk)

\begin{tabular}{|c|c|c|c|c|c|}
\hline $\begin{array}{c}\text { Meters from } \\
\text { obelisk } \\
\text { (estimate) }\end{array}$ & Date-1 & Time-1 & Date-2 & Time-2 & Grid Coordinates \\
\hline 292 & $5 / 8$ & 04:33:19 & $8 / 10$ & $04: 42: 54$ & $-277.18 m,-67.24 m,-1.50 m$ \\
\hline 272 & $5 / 9$ & 04:34:30 & $8 / 9$ & $04: 44: 25$ & $-258.06 m,-61.27 m,-1.50 m$ \\
\hline 255 & $5 / 10$ & $04: 35: 33$ & $8 / 8$ & $04: 45: 42$ & $-242.75 m,-56.56 m,-1.50 m$ \\
\hline 240 & $5 / 11$ & $04: 36: 50$ & $8 / 7$ & 04:47:09 & $-228.12 \mathrm{~m},-52.01 \mathrm{~m},-1.50 \mathrm{~m}$ \\
\hline 226 & $5 / 12$ & $04: 37: 54$ & $8 / 6$ & $04: 48: 18$ & $-216.08 m,-48.39 m,-1.50 m$ \\
\hline 216 & $5 / 13$ & 04:38:58 & $8 / 5$ & $04: 49: 33$ & $-205.11 \mathrm{~m},-45.04 \mathrm{~m},-1.50 \mathrm{~m}$ \\
\hline 206 & $5 / 14$ & 04:40:06 & $8 / 4$ & $04: 50: 46$ & $-195.28 m,-42.04 m,-1.50 m$ \\
\hline 196 & $5 / 15$ & $04: 41: 24$ & $8 / 3$ & 04:52:09 & $-186.93 m,-39.36 m,-1.50 m$ \\
\hline 189 & $5 / 16$ & $04: 42: 31$ & $8 / 2$ & $04: 53: 23$ & $-179.31 \mathrm{~m},-37.05 \mathrm{~m},-1.50 \mathrm{~m}$ \\
\hline 182 & $5 / 17$ & $04: 43: 40$ & $8 / 1$ & $04: 54: 32$ & $-171.45 m,-34.56 m,-1.50 m$ \\
\hline 175 & $5 / 18$ & 04:44:45 & $7 / 31$ & $04: 55: 41$ & $-164.85 m,-32.57 m,-1.50 m$ \\
\hline 167.5 & $5 / 19$ & $04: 45: 48$ & $7 / 30$ & $04: 56: 48$ & $-158.34 m,-30.56 m,-1.50 m$ \\
\hline 162 & $5 / 20$ & $04: 46: 52$ & $7 / 29$ & $04: 57: 34$ & $-152.88 \mathrm{~m},-28.89 \mathrm{~m},-1.50 \mathrm{~m}$ \\
\hline 156 & $5 / 21$ & $04: 47: 58$ & $7 / 28$ & $04: 58: 56$ & $-147.78 m,-27.31 \mathrm{~m},-1.50 \mathrm{~m}$ \\
\hline 151 & $5 / 22$ & 04:49:08 & $7 / 27$ & $04: 59: 53$ & $-142.89 \mathrm{~m},-25.78 \mathrm{~m},-1.50 \mathrm{~m}$ \\
\hline 147.5 & $5 / 23$ & 04:50:03 & $7 / 26$ & 05:00:49 & $-139.11 \mathrm{~m},-24.67 \mathrm{~m},-1.50 \mathrm{~m}$ \\
\hline 143.5 & $5 / 24$ & $04: 51: 14$ & $7 / 25$ & 05:01:50 & $-135.12 m,-23.38 m,-1.50 m$ \\
\hline 140 & $5 / 25$ & 04:52:09 & $7 / 24$ & 05:02:46 & $-131.75 \mathrm{~m},-22.37 \mathrm{~m},-1.50 \mathrm{~m}$ \\
\hline 136 & $5 / 26$ & $04: 53: 18$ & $7 / 23$ & 05:03:40 & $-127.64 m,-21.06 m,-1.50 m$ \\
\hline 134 & $5 / 27$ & $04: 54: 16$ & $7 / 22$ & 05:04:28 & $-125.14 m,-20.33 m,-1.50 m$ \\
\hline 131 & $5 / 28$ & 04:55:11 & $7 / 21$ & $05: 05: 16$ & $-122.23 \mathrm{~m},-19.44 \mathrm{~m},-1.50 \mathrm{~m}$ \\
\hline 128 & $5 / 29$ & 04:56:14 & $7 / 20$ & $05: 05: 18$ & $-119.58 m,-18.60 m,-1.50 m$ \\
\hline 125 & $5 / 30$ & $04: 57: 03$ & $7 / 19$ & $05: 06: 47$ & $-117.09 \mathrm{~m},-17.90 \mathrm{~m},-1.50 \mathrm{~m}$ \\
\hline 123 & $5 / 31$ & 04:58:02 & $7 / 18$ & 05:07:27 & $-113.84 m,-17.18 m,-1.50 m$ \\
\hline
\end{tabular}


The Relationship between the Montecitorio Obelisk and the Ara Pacis 1:87

\begin{tabular}{|l|l|l|l|l|l|}
\hline 120.5 & $6 / 1$ & $04: 59: 02$ & $7 / 17$ & $05: 08: 07$ & $-112.39 \mathrm{~m},-16.41 \mathrm{~m},-1.50 \mathrm{~m}$ \\
\hline 118 & $6 / 2$ & $05: 00: 01$ & $7 / 16$ & $05: 08: 46$ & $-110.70 \mathrm{~m},-15.89 \mathrm{~m},-1.50 \mathrm{~m}$ \\
\hline 116.5 & $6 / 3$ & $05: 00: 45$ & $7 / 15$ & $05: 09: 19$ & $-108.80 \mathrm{~m},-15.31 \mathrm{~m},-1.50 \mathrm{~m}$ \\
\hline 114 & $6 / 4$ & $05: 01: 36$ & $7 / 14$ & $05: 08: 04$ & $-107.03 \mathrm{~m},-14.76 \mathrm{~m},-1.50 \mathrm{~m}$ \\
\hline 111 & $6 / 5$ & $05: 02: 26$ & $7 / 13$ & $05: 10: 23$ & $-105.35 \mathrm{~m},-14.25 \mathrm{~m},-1.50 \mathrm{~m}$ \\
\hline 109 & $6 / 6$ & $05: 03: 14$ & $7 / 12$ & $05: 10: 52$ & $-103.89 \mathrm{~m},-13.79 \mathrm{~m},-1.50 \mathrm{~m}$ \\
\hline 108 & $6 / 7$ & $05: 03: 58$ & $7 / 11$ & $05: 11: 17$ & $-102.40 \mathrm{~m},-13.34 \mathrm{~m},-1.50 \mathrm{~m}$ \\
\hline 107 & $6 / 8$ & $05: 04: 43$ & $7 / 10$ & $05: 10: 15$ & $-101.09 \mathrm{~m},-12.94 \mathrm{~m},-1.50 \mathrm{~m}$ \\
\hline 106 & $6 / 9$ & $05: 05: 42$ & $7 / 9$ & $05: 12: 15$ & $-99.76 \mathrm{~m},-12.45 \mathrm{~m},-1.50 \mathrm{~m}$ \\
\hline 105 & $6 / 10$ & $05: 06: 25$ & $7 / 8$ & $05: 12: 25$ & $-98.63 \mathrm{~m},-12.07 \mathrm{~m},-1.50 \mathrm{~m}$ \\
\hline 104 & $6 / 11$ & $05: 07: 08$ & $7 / 7$ & $05: 12: 59$ & $-97.66 \mathrm{~m},-11.78 \mathrm{~m},-1.50 \mathrm{~m}$ \\
\hline 103.5 & $6 / 12$ & $05: 07: 43$ & $7 / 6$ & $05: 13: 05$ & $-96.80 \mathrm{~m},-11.54 \mathrm{~m},-1.50 \mathrm{~m}$ \\
\hline 103 & $6 / 13$ & $05: 07: 53$ & $7 / 5$ & $05: 13: 20$ & $-95.98 \mathrm{~m},-11.29 \mathrm{~m},-1.50 \mathrm{~m}$ \\
\hline 102.5 & $6 / 14$ & $05: 08: 53$ & $7 / 4$ & $05: 13: 26$ & $-95.29 \mathrm{~m},-11.08 \mathrm{~m},-1.50 \mathrm{~m}$ \\
\hline 102 & $6 / 15$ & $05: 09: 25$ & $7 / 3$ & $05: 13: 35$ & $-94.57 \mathrm{~m},-10.87 \mathrm{~m},-1.50 \mathrm{~m}$ \\
\hline 101 & $6 / 16$ & $05: 09: 57$ & $7 / 2$ & $05: 13: 39$ & $-94.11 \mathrm{~m},-10.73 \mathrm{~m},-1.50 \mathrm{~m}$ \\
\hline 100 & $6 / 17$ & $05: 10: 25$ & $7 / 1$ & $05: 13: 31$ & $-93.54 \mathrm{~m},-10.61 \mathrm{~m},-1.50 \mathrm{~m}$ \\
\hline 99 & $6 / 18$ & $05: 10: 53$ & $6 / 30$ & $05: 13: 43$ & $-92.97 \mathrm{~m},-10.38 \mathrm{~m},-1.50 \mathrm{~m}$ \\
\hline 98.5 & $6 / 19$ & $05: 11: 21$ & $6 / 29$ & $05: 13: 40$ & $-92.54 \mathrm{~m},-10.25 \mathrm{~m},-1.50 \mathrm{~m}$ \\
\hline 98 & $6 / 20$ & $05: 11: 44$ & $6 / 28$ & $05: 13: 17$ & $-92.62 \mathrm{~m},-10.37 \mathrm{~m},-1.50 \mathrm{~m}$ \\
\hline 98 & $6 / 21$ & $05: 11: 46$ & $6 / 27$ & $05: 13: 11$ & $-92.35 \mathrm{~m},-10.28 \mathrm{~m},-1.50 \mathrm{~m}$ \\
\hline 98 & $6 / 22$ & $5: 12: 20$ & $6 / 26$ & $05: 13: 14$ & $-91.84 \mathrm{~m},-10.08 \mathrm{~m},-1.50 \mathrm{~m}$ \\
\hline 97 & $6 / 23$ & $5: 12: 36$ & $6 / 25$ & $05: 13: 04$ & $-91.81 \mathrm{~m},-10.07 \mathrm{~m},-1.50 \mathrm{~m}$ \\
\hline 97 & $6 / 24192$ & $5: 12: 51$ & ---- & & $-91.78 \mathrm{~m},-10.06 \mathrm{~m},-1.50 \mathrm{~m}$ \\
\hline & & & & & \\
\hline
\end{tabular}

Appendix Table 1B: Observations of years 1, 2, and 3 of the four-year leap-year cycle for a random sample of alignments listed on Appendix Table 1A.

\begin{tabular}{|l|l|l|l|l|l|}
\hline $\begin{array}{c}\text { Year in } \\
\text { cycle }\end{array}$ & \multicolumn{1}{|c|}{ Date-1 } & \multicolumn{1}{|c|}{ Time-1 } & \multicolumn{1}{|c|}{ Date-2 } & \multicolumn{1}{c|}{ Time-2 } & \multicolumn{1}{c|}{ Grid Coordinates } \\
\hline 1 & $5 / 20$ & $04: 46: 52$ & $7 / 29$ & $04: 57: 34$ & $-152.88 \mathrm{~m},-28.89 \mathrm{~m},-1.50 \mathrm{~m}$ \\
\hline 2 & « & $04: 46: 27$ & “ & $04: 57: 46$ & $-153.92 \mathrm{~m},-29.29 \mathrm{~m},-1.50 \mathrm{~m}$ \\
\hline 3 & “ & $04: 46: 12$ & “ & $04: 57: 58$ & $-155.45 \mathrm{~m},-29.75 \mathrm{~m},-1.50 \mathrm{~m}$ \\
\hline 1 & $5 / 30$ & $04: 57: 03$ & $7 / 19$ & $05: 06: 47$ & $-117.09 \mathrm{~m},-17.90 \mathrm{~m},-1.50 \mathrm{~m}$ \\
\hline 2 & « & $04: 56: 46$ & “ & $05: 06: 45$ & $-117.97 \mathrm{~m},-18.17 \mathrm{~m},-1.50 \mathrm{~m}$ \\
\hline
\end{tabular}

\footnotetext{
${ }^{192}$ The summer solstice in 9 BC according to NASA's calculator: http://data.giss.nasa.gov/ar5/srvernal.html
} 


\begin{tabular}{|l|l|l|l|l|l|}
\hline 3 & “ & $04: 56: 29$ & “ & $05: 06: 47$ & $-118.37 \mathrm{~m},-18.30 \mathrm{~m},-1.50 \mathrm{~m}$ \\
\hline 1 & $6 / 17$ & $05: 10: 16$ & $7 / 1$ & $05: 13: 31$ & $-93.54 \mathrm{~m},-10.61 \mathrm{~m},-1.50 \mathrm{~m}$ \\
\hline 2 & “ & $5: 10: 11$ & “ & $05: 13: 30$ & $-93.69 \mathrm{~m},-10.66 \mathrm{~m},-1.50 \mathrm{~m}$ \\
\hline 3 & “ & $5: 10: 10$ & “ & $05: 13: 30$ & $-93.69 \mathrm{~m},-10.66 \mathrm{~m},-1.50 \mathrm{~m}$ \\
\hline
\end{tabular}

Appendix Table 1C: Stress tests with 30.7 m obelisk

\begin{tabular}{|l|l|l|l|l|l|}
\hline $\begin{array}{c}\text { Meters from } \\
\text { obelisk } \\
\text { (estimate) }\end{array}$ & Date-1 & \multicolumn{1}{|c|}{ Time-1 } & \multicolumn{1}{|c|}{ Date-2 } & \multicolumn{1}{c|}{ Time-2 } & \multicolumn{1}{c|}{ Grid Coordinates } \\
\hline 170 & $5 / 21$ & $04: 45: 16$ & $7 / 28$ & $04: 56: 06$ & $-160.72 \mathrm{~m},-33.66 \mathrm{~m},-1.50 \mathrm{~m}$ \\
\hline 165 & $5 / 22$ & $04: 46: 18$ & $7 / 27$ & $04: 57: 08$ & $-155.69 \mathrm{~m},-32.07 \mathrm{~m},-1.50 \mathrm{~m}$ \\
\hline 159 & $5 / 23$ & $04: 47: 21$ & $7 / 26$ & $04: 58: 09$ & $-150.65 \mathrm{~m},-30.48 \mathrm{~m},-1.50 \mathrm{~m}$ \\
\hline 105 & $6 / 22$ & $5: 09: 17$ & $6 / 26$ & $05: 10: 17$ & $-98.90 \mathrm{~m},-14.08 \mathrm{~m},-1.50 \mathrm{~m}$ \\
\hline 103 & $6 / 23$ & $5: 09: 48$ & $6 / 25$ & $05: 10: 11$ & $-98.90 \mathrm{~m},-14.08 \mathrm{~m},-1.50 \mathrm{~m}$ \\
\hline 103 & $6 / 24$ & $5: 09: 58$ & ---- & & $-98.24 \mathrm{~m},-13.89 \mathrm{~m},-1.50 \mathrm{~m}$ \\
\hline
\end{tabular}

Appendix Table 1D: Stress tests of $29.6 \mathrm{~m}$ obelisk with $5 \mathrm{~cm}$ of subsidence to the southwest

Year: 9 BC

Method: three randomly chosen dates from Appendix Table $1 \mathrm{~A}$ were tested to see if the dates of alignment would be changed or invalidated after the $29.6 \mathrm{~m}$ obelisk had subsided $5 \mathrm{~cm}$.

\begin{tabular}{|l|l|l|l|l|l|}
\hline $\begin{array}{c}\text { Meters from obelisk } \\
\text { (estimate) })^{193}\end{array}$ & Date-1 & Time-1 & \multicolumn{1}{|c|}{ Date-2 $^{\text {194 }}$} & Time-2 & \multicolumn{1}{c|}{ Grid Coordinates $^{\text {195 }}$} \\
\hline $\begin{array}{l}194 \\
(182)\end{array}$ & $5 / 15$ & $4: 41: 40$ & $\begin{array}{l}8 / 3 \\
(8 / 1)\end{array}$ & $4: 52: 33$ & $\begin{array}{l}-184.61 \mathrm{~m},-38.62 \mathrm{~m},-1.50 \mathrm{~m} \\
(-186.93 \mathrm{~m},-39.36 \mathrm{~m},-1.50 \mathrm{~m})\end{array}$ \\
\hline $\begin{array}{l}138 \\
(140)\end{array}$ & $5 / 25$ & $4: 52: 33$ & $7 / 24$ & $5: 03: 09$ & $-131.00 \mathrm{~m},-22.21 \mathrm{~m},-1.50 \mathrm{~m}(-$ \\
116 & $6 / 2$ & $5: 00: 33$ & $7 / 16$ & $5: 09: 25$ & $\begin{array}{l}-109.62 \mathrm{~m},-15.56 \mathrm{~m},-1.50 \mathrm{~m} \\
(-110.70 \mathrm{~m},-15.89 \mathrm{~m},-1.50 \mathrm{~m})\end{array}$ \\
\hline
\end{tabular}

${ }^{193}$ Number in parentheses is estimated of meters from obelisk in the simulation without subsidence of the $29.6 \mathrm{~m}$ obelisk.

${ }^{194}$ Date in parentheses is best date of the second alignment in the year in the simulation without the subsidence of the $29.6 \mathrm{~m}$ obelisk.

${ }^{195}$ Coordinates in parentheses are those of the simulation without subsidence of the $29.6 \mathrm{~m}$ obelisk. 
The Relationship between the Montecitorio Obelisk and the Ara Pacis 1:89

Appendix Table 2: Report on solar alignments from the west entrance of the Ara Pacis to the obelisk

Zone: 2

Software used: Stellarium

3d plug-ins: 3d Sceneries (a) Meridian Augusti revised (=29.6 m obelisk); (b) 30.7m Obelisk (used in stress tests)

Settings: View-Markings-Projection: Perspective.

Height of gnomon: $29.6 \mathrm{~m}$ (100 Roman feet)

Year investigated: 9 BC (“- 8 ” on Stellarium's clock)

Time: UTC

Alignment: obelisk's finial centered on sun's disk

Year: 9 BC

Observer: Bernard Frischer Date: 8/12/2015

Note 1: On the following table, the measurements in meters are approximate and are offered to give users a quick idea of where to move Stellarium's camera. The Grid Coordinates are exact.

Note 2: On the table, Date-1 and Time-1 give the times when the centers of the finial and solar disk closely coincide. Date-2 and Time2 give the equivalent dates later in the year. Usually, the centers do not coincide as closely on these latter dates. The slight difference is detectable at the small FOVs used for analytical purposes but not at the more realistic FOV of $90^{\circ}$ which approximates what the ancient observer will have seen.

Note 3: In the published version of the simulation, the user may go directly to the grid coordinates indicated on the table. To do so, open the Configuration Window (the wrench icon on the left side of the screen). Select Plugins and click "configure" in the bottom left. In the 3d Scenery window, click on "Load/save viewpoints." A list of stored viewpoints is displayed. Click on the date as per Date1 on the tale below. Stellarium moves the camera to the appropriate grid coordinates. Stellarium does not, however, change the date or time. Do this by click on the clock icon on the left side of the screen. Set the date to 132 (AD); and key in the appropriate month, day, hour, minute, and second, as per the table below.

Note 4: Since at present it is not possible to lock the camera onto a fixed path in Stellarium, the data that follows below are only approximately correct. We estimate they are accurate to $\pm 10.00 \mathrm{~m}$ and \pm 30 minutes. Since the point of the table is to show that, without doubt, there are many solar alignments in the area of the Ara Pacis and obelisk, we consider this degree of accuracy to be acceptable.

Note 5: As noted in the text, the first two alignments (at ca. 90 meters and 89 meters) are intervisible. The rest are interpositional.

Appendix Table 2A: Dates and times of alignment (29.6 m obelisk)

\begin{tabular}{|l|l|l|l|l|l|}
\hline $\begin{array}{c}\text { Meters from } \\
\text { obelisk } \\
\text { (estimate) }\end{array}$ & Date-1 & \multicolumn{1}{|c|}{ Time-1 } & \multicolumn{1}{|c|}{ Date-2 } & \multicolumn{1}{|c|}{ Time-2 } & \multicolumn{1}{c|}{ Grid Coordinates } \\
\hline 91 & $3 / 19$ & $15: 45: 21$ & $9 / 27$ & $15: 28: 21$ & $90.84 \mathrm{~m}, 45.60 \mathrm{~m}, 1.01 \mathrm{~m}$ \\
\hline 88 & $3 / 20$ & $15: 41: 13$ & $9 / 26$ & $15: 24: 46$ & $88.19 \mathrm{~m}, 45.48 \mathrm{~m}, 0.15 \mathrm{~m}$ \\
\hline 88 & $3 / 21$ & $15: 41: 28$ & $9 / 25$ & $15: 25: 37$ & $87.76 \mathrm{~m}, 44.68 \mathrm{~m}, 0.06 \mathrm{~m}$ \\
\hline 86 & $3 / 22$ & $15: 39: 31$ & $9 / 24$ & $15: 24: 16$ & $86.46 \mathrm{~m}, 44.30 \mathrm{~m},-0.49 \mathrm{~m}$ \\
\hline 85 & $3 / 23$ & $15: 37: 29$ & $9 / 23$ & $15: 22: 49$ & $85.00 \mathrm{~m}, 43.88 \mathrm{~m},-0.89 \mathrm{~m}$ \\
\hline 84 & $3 / 24$ & $15: 35: 30$ & $9 / 22$ & $15: 21: 29$ & $84.00 \mathrm{~m}, 43.58 \mathrm{~m},-1.50 \mathrm{~m}$ \\
\hline 81 & $3 / 25$ & $15: 33: 32$ & $9 / 21$ & $15: 20: 13$ & $81.49 \mathrm{~m}, 42.81 \mathrm{~m},-1.50 \mathrm{~m}$ \\
\hline 79 & $3 / 26$ & $15: 31: 35$ & $9 / 20$ & $15: 18: 53$ & $79.15 \mathrm{~m}, 42.12 \mathrm{~m},-1.50 \mathrm{~m}$ \\
\hline
\end{tabular}




\begin{tabular}{|c|c|c|c|c|c|}
\hline 77 & $3 / 27$ & $15: 29: 33$ & $9 / 19$ & $15: 17: 28$ & $76.85 \mathrm{~m}, 41.43 \mathrm{~m},-1.50 \mathrm{~m}$ \\
\hline 75 & $3 / 28$ & $15: 27: 32$ & $9 / 18$ & $15: 16: 06$ & $74.66 m, 40.78 m,-1.50 m$ \\
\hline 72 & $3 / 29$ & $15: 25: 36$ & $9 / 17$ & $15: 14: 44$ & $72.75 \mathrm{~m}, 40.21 \mathrm{~m},-1.50 \mathrm{~m}$ \\
\hline 70 & $3 / 30$ & $15: 23: 35$ & $9 / 16$ & $15: 13: 24$ & $70.69 \mathrm{~m}, 39.59 \mathrm{~m},-1.50 \mathrm{~m}$ \\
\hline 69 & $3 / 31$ & $15: 21: 39$ & $9 / 15$ & $15: 11: 59$ & $68.93 \mathrm{~m}, 39.07 \mathrm{~m},-1.50 \mathrm{~m}$ \\
\hline 67 & $4 / 1$ & $15: 19: 42$ & $9 / 14$ & $15: 10: 39$ & $67.19 \mathrm{~m}, 38.55 \mathrm{~m},-1.50 \mathrm{~m}$ \\
\hline 65 & $4 / 2$ & $15: 17: 27$ & $9 / 13$ & $15: 09: 23$ & $65.35 \mathrm{~m}, 38.05 \mathrm{~m},-1.50 \mathrm{~m}$ \\
\hline 64 & $4 / 3$ & $15: 14: 21$ & $9 / 12$ & $15: 07: 51$ & $63.13 m, 37.64 m,-1.50 m$ \\
\hline 62 & $4 / 4$ & $15: 12: 17$ & $9 / 11$ & $15: 05: 04$ & $61.57 \mathrm{~m}, 37.19 \mathrm{~m},-1.50 \mathrm{~m}$ \\
\hline 60 & $4 / 5$ & $15: 10: 18$ & $9 / 10$ & $15: 03: 44$ & $60.11 \mathrm{~m}, 36.76 \mathrm{~m},-1.50 \mathrm{~m}$ \\
\hline 59 & $4 / 6$ & $15: 08: 15$ & $9 / 9$ & $15: 02: 31$ & $58.71 \mathrm{~m}, 36.36 \mathrm{~m},-1.50 \mathrm{~m}$ \\
\hline 57 & $4 / 7$ & $15: 06: 31$ & $9 / 8$ & $15: 01: 21$ & $57.35 \mathrm{~m}, 35.86 \mathrm{~m},-1.50 \mathrm{~m}$ \\
\hline 56 & $4 / 8$ & $15: 04: 44$ & $9 / 8^{196}$ & 15:01:19 & $56.29 \mathrm{~m}, 35.52 \mathrm{~m},-1.50 \mathrm{~m}$ \\
\hline 55 & $4 / 9$ & $15: 02: 44$ & $9 / 7$ & $15: 00: 02$ & $54.88 \mathrm{~m}, 35.09 \mathrm{~m},-1.50 \mathrm{~m}$ \\
\hline 54 & $4 / 10$ & $15: 00: 57$ & $9 / 6$ & $14: 58: 40$ & $53.93 \mathrm{~m}, 34.80 \mathrm{~m},-1.50 \mathrm{~m}$ \\
\hline 53 & $4 / 11$ & $14: 59: 10$ & $9 / 5$ & $14: 57: 22$ & $52.89 \mathrm{~m}, 34.48 \mathrm{~m},-1.50 \mathrm{~m}$ \\
\hline 52 & $4 / 12$ & $14: 56: 58$ & $9 / 4$ & $14: 55: 28$ & $51.70 \mathrm{~m}, 34.18 \mathrm{~m},-1.50 \mathrm{~m}$ \\
\hline 50 & $4 / 13$ & $14: 54: 53$ & $9 / 3$ & $14: 54: 07$ & $50.54 \mathrm{~m}, 33.86 \mathrm{~m},-1.50 \mathrm{~m}$ \\
\hline 49 & $4 / 14$ & $14: 52: 45$ & $9 / 2$ & $14: 52: 45$ & $49.43 m, 33.57 \mathrm{~m},-1.50 \mathrm{~m}$ \\
\hline 48 & $4 / 15$ & $14: 50: 40$ & $9 / 1$ & $14: 51: 01$ & $48.39 \mathrm{~m}, 33.29 \mathrm{~m},-1.50 \mathrm{~m}$ \\
\hline 47 & $4 / 16$ & $14: 48: 36$ & $8 / 31$ & $14: 49: 28$ & $47.41 \mathrm{~m}, 33.02 \mathrm{~m},-1.50 \mathrm{~m}$ \\
\hline 46 & $4 / 17$ & $14: 46: 31$ & $8 / 30$ & $14: 47: 50$ & $46.39 \mathrm{~m}, 32.75 \mathrm{~m},-1.50 \mathrm{~m}$ \\
\hline 45 & $4 / 18$ & $14: 44: 31$ & $8 / 29$ & $14: 46: 40$ & $45.52 \mathrm{~m}, 32.51 \mathrm{~m},-1.50 \mathrm{~m}$ \\
\hline 44 & $4 / 19$ & $14: 42: 29$ & $8 / 28$ & 14:46:09 & $44.55 \mathrm{~m}, 32.25 \mathrm{~m},-1.50 \mathrm{~m}$ \\
\hline 44 & $4 / 20$ & $14: 42: 18$ & $8 / 27$ & $14: 45: 18$ & $44.24 \mathrm{~m}, 31.88 \mathrm{~m},-1.50 \mathrm{~m}$ \\
\hline 43 & $4 / 21$ & $14: 40: 37$ & $8 / 26$ & $14: 43: 37$ & $43.42 \mathrm{~m}, 31.62 \mathrm{~m},-1.50 \mathrm{~m}$ \\
\hline 43 & $4 / 22$ & 14:39:01 & $8 / 25$ & $14: 42: 50$ & $42.88 \mathrm{~m}, 31.45 \mathrm{~m},-1.50 \mathrm{~m}$ \\
\hline 42 & $4 / 23$ & $14: 34: 29$ & $8 / 25$ & $14: 40: 08$ & $42.08 m, 31.16 m,-1.50 m$ \\
\hline 41 & $4 / 24$ & $14: 35: 21$ & $8 / 24$ & $14: 41: 38$ & $41.24 \mathrm{~m}, 30.92 \mathrm{~m},-1.50 \mathrm{~m}$ \\
\hline 40 & $4 / 25$ & $14: 33: 32$ & $8 / 23$ & $14: 40: 20$ & $40.64 m, 30.74 m,-1.50 m$ \\
\hline 40 & $4 / 26$ & $14: 31: 54$ & $8 / 22$ & $14: 38: 54$ & $39.79 \mathrm{~m}, 30.48 \mathrm{~m},-1.50 \mathrm{~m}$ \\
\hline 39 & $4 / 27$ & $14: 30: 17$ & $8 / 21$ & $14: 37: 38$ & $39.27 \mathrm{~m}, 30.31 \mathrm{~m},-1.50 \mathrm{~m}$ \\
\hline 38 & $4 / 28$ & $14: 28: 38$ & $8 / 20$ & $14: 36: 25$ & $38.67 \mathrm{~m}, 30.13 \mathrm{~m},-1.50 \mathrm{~m}$ \\
\hline 38 & $4 / 29$ & $14: 26: 55$ & $8 / 19$ & $14: 25: 16$ & $38.07 \mathrm{~m}, 29.94 \mathrm{~m},-1.50 \mathrm{~m}$ \\
\hline 37 & $4 / 30$ & $14: 25: 22$ & $8 / 18$ & $14: 33: 53$ & $37.46 \mathrm{~m}, 29.76 \mathrm{~m},-1.50 \mathrm{~m}$ \\
\hline
\end{tabular}

$1969 / 8$ is a better fit than $9 / 7$. 
The Relationship between the Montecitorio Obelisk and the Ara Pacis 1:91

\begin{tabular}{|c|c|c|c|c|c|}
\hline 37 & $5 / 1$ & $14: 23: 48$ & $8 / 17$ & $14: 32: 29$ & $36.88 m, 29.58 m,-1.50 m$ \\
\hline 36 & $5 / 2$ & $14: 22: 14$ & $8 / 16$ & $14: 31: 14$ & $36.32 \mathrm{~m}, 29.41 \mathrm{~m},-1.50 \mathrm{~m}$ \\
\hline 35 & $5 / 3$ & $14: 20: 34$ & $8 / 15$ & $14: 29: 43$ & $35.53 m, 29.18 m,-1.50 m$ \\
\hline 35 & $5 / 4$ & $14: 19: 04$ & $8 / 14$ & $14: 28: 29$ & $35.17 \mathrm{~m}, 29.07 \mathrm{~m},-1.50 \mathrm{~m}$ \\
\hline 34 & $5 / 5$ & $14: 17: 24$ & $8 / 13$ & $14: 27: 07$ & $34.62 \mathrm{~m}, 28.91 \mathrm{~m},-1.50 \mathrm{~m}$ \\
\hline 34 & $5 / 6$ & $14: 15: 57$ & $8 / 12$ & $14: 25: 46$ & $34.15 \mathrm{~m}, 28.77 \mathrm{~m},-1.50 \mathrm{~m}$ \\
\hline 33 & $5 / 7$ & $14: 14: 20$ & $8 / 11$ & $14: 24: 27$ & $33.66 \mathrm{~m}, 28.63 \mathrm{~m},-1.50 \mathrm{~m}$ \\
\hline 33 & $5 / 8$ & $14: 12: 47$ & $8 / 10$ & $14: 23: 07$ & $33.14 m, 28.48 m,-1.50 m$ \\
\hline 33 & $5 / 9$ & $14: 11: 23$ & $8 / 9$ & $14: 21: 41$ & $32.72 \mathrm{~m}, 28.35 \mathrm{~m},-1.50 \mathrm{~m}$ \\
\hline 32 & $5 / 10$ & 14:09:40 & $8 / 8$ & $14: 19: 56$ & $32.22 \mathrm{~m}, 28.15 \mathrm{~m},-1.50 \mathrm{~m}$ \\
\hline 32 & $5 / 11$ & 14:08:34 & $8 / 7$ & $14: 19: 04$ & $31.82 \mathrm{~m}, 28.09 \mathrm{~m},-1.50 \mathrm{~m}$ \\
\hline 31 & $5 / 12$ & $14: 06: 54$ & $8 / 6$ & $14: 17: 23$ & $31.40 \mathrm{~m}, 27.97 \mathrm{~m},-1.50 \mathrm{~m}$ \\
\hline 31 & $5 / 13$ & $14: 05: 41$ & $8 / 5$ & $14: 16: 12$ & $30.97 \mathrm{~m}, 27.84 \mathrm{~m},-1.50 \mathrm{~m}$ \\
\hline 30 & $5 / 14$ & 14:04:19 & $8 / 4$ & $14: 15: 19$ & $30.58 m, 27.73 m,-1.50 m$ \\
\hline 30 & $5 / 15$ & 14:03:02 & $8 / 3$ & $14: 13: 40$ & $30.19 \mathrm{~m}, 27.62 \mathrm{~m},-1.50 \mathrm{~m}$ \\
\hline 30 & $5 / 16$ & $14: 01: 39$ & $8 / 2$ & $14: 12: 39$ & $29.81 \mathrm{~m}, 27.51 \mathrm{~m},-1.50 \mathrm{~m}$ \\
\hline 29 & $5 / 17$ & $14: 00: 24$ & $8 / 1$ & $14: 11: 24$ & $29.47 \mathrm{~m}, 27.41 \mathrm{~m},-1.50 \mathrm{~m}$ \\
\hline 29 & $5 / 18$ & 13:59:11 & $7 / 31$ & 14:10:11 & $29.12 \mathrm{~m}, 27.31 \mathrm{~m},-1.50 \mathrm{~m}$ \\
\hline 29 & $5 / 19$ & $13: 57: 52$ & $7 / 30$ & $14: 08: 28$ & $28.74 m, 27.20 m,-1.50 m$ \\
\hline 28 & $5 / 20$ & $13: 56: 37$ & $7 / 29$ & $14: 07: 37$ & $28.42 \mathrm{~m}, 27.11 \mathrm{~m},-1.50 \mathrm{~m}$ \\
\hline 28 & $5 / 21$ & $13: 55: 26$ & $7 / 28$ & $14: 06: 26$ & $28.09 \mathrm{~m}, 27.02 \mathrm{~m},-1.50 \mathrm{~m}$ \\
\hline 28 & $5 / 22$ & $13: 54: 26$ & $7 / 27$ & $14: 05: 21$ & $27.82 \mathrm{~m}, 26.95 \mathrm{~m},-1.50 \mathrm{~m}$ \\
\hline 27 & $5 / 23$ & $13: 53: 21$ & $7 / 26$ & $14: 03: 37$ & $27.47 \mathrm{~m}, 26.85 \mathrm{~m},-1.50 \mathrm{~m}$ \\
\hline 27 & $5 / 24$ & $13: 52: 14$ & $7 / 25$ & 14:02:31 & $27.19 \mathrm{~m}, 26.77 \mathrm{~m},-1.50 \mathrm{~m}$ \\
\hline 27 & $5 / 25$ & $13: 51: 18$ & $7 / 24$ & $14: 01: 29$ & $26.94 \mathrm{~m}, 26.70 \mathrm{~m},-1.50 \mathrm{~m}$ \\
\hline 26 & $5 / 26$ & $13: 50: 19$ & $7 / 23$ & $14: 00: 29$ & $26.69 \mathrm{~m}, 26.63 \mathrm{~m},-1.50 \mathrm{~m}$ \\
\hline 26 & $5 / 27$ & $13: 48: 57$ & $7 / 22$ & $13: 58: 47$ & $26.31 \mathrm{~m}, 26.53 \mathrm{~m},-1.50 \mathrm{~m}$ \\
\hline 26 & $5 / 28$ & $13: 48: 13$ & $7 / 21$ & $13: 58: 08$ & $26.13 m, 26.47 m,-1.50 m$ \\
\hline 26 & $5 / 29$ & $13: 47: 30$ & $7 / 20$ & $13: 56: 49$ & $25.89 \mathrm{~m}, 26.40 \mathrm{~m},-1.50 \mathrm{~m}$ \\
\hline 26 & $5 / 30$ & $13: 46: 38$ & $7 / 19$ & $13: 55: 51$ & $25.70 m, 26.35 m,-1.50 m$ \\
\hline 25 & $5 / 31$ & $13: 45: 36$ & $7 / 18$ & $13: 54: 32$ & $25.41 \mathrm{~m}, 26.26 \mathrm{~m},-1.50 \mathrm{~m}$ \\
\hline 25 & $6 / 1$ & $13: 44: 57$ & $7 / 17$ & $13: 53: 47$ & $25.22 \mathrm{~m}, 26.21 \mathrm{~m},-1.50 \mathrm{~m}$ \\
\hline 25 & $6 / 2$ & $13: 44: 07$ & $7 / 16$ & $13: 52: 38$ & $24.98 m, 26.14 m,-1.50 m$ \\
\hline 25 & $6 / 3$ & $13: 43: 38$ & $7 / 15$ & $13: 51: 54$ & $24.79 \mathrm{~m}, 26.08 \mathrm{~m},-1.50 \mathrm{~m}$ \\
\hline 24 & $6 / 4$ & $13: 42: 54$ & $7 / 14$ & $13: 50: 54$ & $24.63 \mathrm{~m}, 26.04 \mathrm{~m},-1.50 \mathrm{~m}$ \\
\hline 24 & $6 / 5$ & $13: 42: 21$ & $7 / 13$ & $13: 50: 15$ & $24.52 \mathrm{~m}, 26.00 \mathrm{~m},-1.50 \mathrm{~m}$ \\
\hline 24 & $6 / 6$ & $13: 41: 48$ & $7 / 12$ & $13: 49: 05$ & $24.30 \mathrm{~m}, 25.94 \mathrm{~m},-1.50 \mathrm{~m}$ \\
\hline
\end{tabular}




\begin{tabular}{|l|l|l|l|l|l|}
\hline 24 & $6 / 7$ & $13: 41: 10$ & $7 / 11$ & $13: 48: 28$ & $24.14 \mathrm{~m}, 25.89 \mathrm{~m},-1.50 \mathrm{~m}$ \\
\hline 24 & $6 / 8$ & $13: 40: 33$ & $7 / 10$ & $13: 47: 28$ & $24.00 \mathrm{~m}, 25.85 \mathrm{~m},-1.50 \mathrm{~m}$ \\
\hline 24 & $6 / 9$ & $13: 40: 28$ & $7 / 9$ & $13: 46: 30$ & $23.86 \mathrm{~m}, 25.81 \mathrm{~m},-1.50 \mathrm{~m}$ \\
\hline 24 & $6 / 10$ & $13: 40: 08$ & $7 / 8$ & $13: 46: 00$ & $23.74 \mathrm{~m}, 25.77 \mathrm{~m},-1.50 \mathrm{~m}$ \\
\hline 24 & $6 / 11$ & $13: 40: 00$ & $7 / 7$ & $13: 45: 16$ & $23.74 \mathrm{~m}, 25.77 \mathrm{~m},-1.50 \mathrm{~m}$ \\
\hline 24 & $6 / 12$ & $13: 39: 29$ & $7 / 6$ & $13: 44: 29$ & $23.51 \mathrm{~m}, 25.71 \mathrm{~m},-1.50 \mathrm{~m}$ \\
\hline 23 & $6 / 13$ & $13: 38: 47$ & $7 / 5$ & $13: 43: 41$ & $23.36 \mathrm{~m}, 25.66 \mathrm{~m},-1.50 \mathrm{~m}$ \\
\hline 23 & $6 / 14$ & $13: 38: 28$ & $7 / 4$ & $13: 42: 51$ & $23.22 \mathrm{~m}, 25.62 \mathrm{~m},-1.50 \mathrm{~m}$ \\
\hline 23 & $6 / 15$ & $13: 38: 32$ & $7 / 3$ & $13: 42: 31$ & $23.18 \mathrm{~m}, 25.61 \mathrm{~m},-1.50 \mathrm{~m}$ \\
\hline 23 & $6 / 16$ & $13: 38: 29$ & $7 / 2$ & $13: 41: 58$ & $23.15 \mathrm{~m}, 25.59 \mathrm{~m},-1.50 \mathrm{~m}$ \\
\hline 23 & $6 / 17$ & $13: 38: 18$ & $7 / 1$ & $13: 41: 32$ & $23.07 \mathrm{~m}, 25.56 \mathrm{~m},-1.50 \mathrm{~m}$ \\
\hline 23 & $6 / 18$ & $13: 38: 32$ & $6 / 30$ & $13: 41: 13$ & $23.05 \mathrm{~m}, 25.56 \mathrm{~m},-1.50 \mathrm{~m}$ \\
\hline 23 & $6 / 19$ & $13: 38: 24$ & $6 / 29$ & $13: 40: 33$ & $22.97 \mathrm{~m}, 25.54 \mathrm{~m},-1.50 \mathrm{~m}$ \\
\hline 23 & $6 / 20$ & $13: 38: 33$ & $6 / 28$ & $13: 40: 11$ & $22.94 \mathrm{~m}, 25.53 \mathrm{~m},-1.50 \mathrm{~m}$ \\
\hline 23 & $6 / 21$ & $13: 38: 36$ & $6 / 27$ & $13: 39: 50$ & $22.91 \mathrm{~m}, 25.52 \mathrm{~m},-1.50 \mathrm{~m}$ \\
\hline 23 & $6 / 22$ & $13: 38: 50$ & $6 / 26$ & $13: 39: 47$ & $22.91 \mathrm{~m}, 25.52 \mathrm{~m},-1.50 \mathrm{~m}$ \\
\hline 23 & $6 / 23$ & $13: 39: 20$ & $6 / 25$ & $13: 39: 20$ & $22.91 \mathrm{~m}, 25.52 \mathrm{~m},-1.50 \mathrm{~m}$ \\
\hline 23 & $6 / 24$ & $13: 38: 58$ & ---- & & $22.90 \mathrm{~m}, 25.51 \mathrm{~m},-1.50 \mathrm{~m}$ \\
\hline
\end{tabular}

Appendix Table 2B: Observations of years 1,2, and 3 of the four-year leap-year cycle for a random sample of alignments listed on Table A.

\begin{tabular}{|l|l|l|l|l|l|}
\hline $\begin{array}{c}\text { Year in } \\
\text { cycle }\end{array}$ & \multicolumn{1}{|c|}{ Date-1 } & \multicolumn{1}{|c|}{ Time-1 } & \multicolumn{1}{|c|}{ Date-2 } & \multicolumn{1}{c|}{ Time-2 } & \multicolumn{1}{c|}{ Grid Coordinates } \\
\hline 1 & $3 / 21^{197}$ & $15: 39: 44$ & $9 / 25$ & $15: 23: 55$ & $90.52 \mathrm{~m}, 46.05 \mathrm{~m},-1.50 \mathrm{~m}$ \\
\hline 2 & “ & $15: 40: 09$ & $9 / 25$ & $15: 23: 31$ & $91.15 \mathrm{~m}, 46.26 \mathrm{~m},-1.50 \mathrm{~m}$ \\
\hline 3 & “ & $15: 40: 38$ & $9 / 26^{198}$ & $15: 24: 28$ & $91.96 \mathrm{~m}, 46.51 \mathrm{~m},-1.50 \mathrm{~m}$ \\
\hline 1 & $3 / 28$ & $15: 25: 45$ & $9 / 18$ & $15: 14: 26$ & $73.32 \mathrm{~m}, 40.81 \mathrm{~m},-1.50 \mathrm{~m}$ \\
\hline 2 & “ & $15: 26: 16$ & $9 / 19$ & $15: 15: 20$ & $73.77 \mathrm{~m}, 40.97 \mathrm{~m},-1.50 \mathrm{~m}$ \\
\hline 3 & “ & $15: 26: 44$ & “ & $15: 14: 59$ & $74.28 \mathrm{~m}, 41.13 \mathrm{~m},-1.50 \mathrm{~m}$ \\
\hline 1 & $4 / 3$ & $15: 14: 10$ & $9 / 12$ & $15: 06: 25$ & $62.80 \mathrm{~m}, 37.55 \mathrm{~m},-1.50 \mathrm{~m}$ \\
\hline 2 & “ & $15: 15: 14$ & $9 / 13$ & $15: 07: 57$ & $63.59 \mathrm{~m}, 37.71 \mathrm{~m},-1.50 \mathrm{~m}$ \\
\hline 3 & “ & & “ & $15: 07: 33$ & $63.03 \mathrm{~m}, 37.54 \mathrm{~m},-1.50 \mathrm{~m}$ \\
\hline
\end{tabular}

\footnotetext{
${ }^{197}$ Vernal equinox in 9 BC according to NASA; see: http://data.giss.nasa.gov/ar5/srvernal.html
}

${ }^{198}$ Note the change in date. 
The Relationship between the Montecitorio Obelisk and the Ara Pacis 1:93

Appendix Table 2C: Stress tests with 30.7 m obelisk

\begin{tabular}{|l|l|l|l|l|l|}
\hline $\begin{array}{c}\text { Meters from } \\
\text { obelisk } \\
\text { (estimate) }\end{array}$ & Date-1 & \multicolumn{1}{|c|}{ Time-1 } & \multicolumn{1}{|c|}{ Date-2 } & \multicolumn{1}{c|}{ Time-2 } & \multicolumn{1}{c|}{ Grid Coordinates } \\
\hline 90 & $3 / 21^{199}$ & $15: 36: 25$ & $9 / 25$ & $15: 20: 35$ & $90.34 \mathrm{~m}, 46.04 \mathrm{~m},-1.50 \mathrm{~m}$ \\
\hline 87.5 & $3 / 22$ & $15: 34: 26$ & $9 / 24$ & $15: 19: 14$ & $87.53 \mathrm{~m}, 45.15 \mathrm{~m},-1.50 \mathrm{~m}$ \\
\hline 85 & $3 / 23$ & $15: 32: 30$ & $9 / 23$ & $15: 18: 20$ & $84.94 \mathrm{~m}, 44.33 \mathrm{~m},-1.50 \mathrm{~m}$ \\
\hline 63.5 & $4 / 3$ & $15: 10: 51$ & $9 / 12$ & $15: 03: 17$ & $63.46 \mathrm{~m}, 37.50 \mathrm{~m},-1.50 \mathrm{~m}$ \\
\hline 62 & $4 / 4$ & $15: 09: 05$ & $9 / 11$ & $15: 01: 50$ & $62.08 \mathrm{~m}, 37.07 \mathrm{~m},-1.50 \mathrm{~m}$ \\
\hline 60 & $4 / 5$ & $15: 07: 04$ & $9 / 10$ & $15: 00: 24$ & $60.58 \mathrm{~m}, 36.61 \mathrm{~m},-1.50 \mathrm{~m}$ \\
\hline
\end{tabular}

Appendix Table 2D: Stress tests of $29.6 \mathrm{~m}$ obelisk with $5 \mathrm{~cm}$ of subsidence to the southwest

Year: 9 BC

Method: three randomly chosen dates from Appendix Table $2 \mathrm{~A}$ were tested to see if the dates of alignment would be changed or invalidated after the $29.6 \mathrm{~m}$ obelisk had subsided $5 \mathrm{~cm}$.

\begin{tabular}{|l|l|l|l|l|l|}
\hline $\begin{array}{c}\text { Meters from obelisk } \\
\text { (estimate) })^{200}\end{array}$ & Date-1 & Time-1 & \multicolumn{1}{|c|}{ Date-2 $^{201}$} & \multicolumn{1}{c|}{ Time-2 $^{\text {Grid Coordinates }^{202}}$} \\
\hline $\begin{array}{l}89.5 \\
(90)\end{array}$ & $3 / 21^{203}$ & $15: 39: 09$ & $9 / 25$ & $15: 23: 21$ & $\begin{array}{l}89.65 \mathrm{~m}, 45.74 \mathrm{~m},-1.50 \mathrm{~m} \\
(90.52 \mathrm{~m}, 46.05 \mathrm{~m},-1.50 \mathrm{~m})\end{array}$ \\
\hline $\begin{array}{l}74 \\
(75)\end{array}$ & $3 / 27$ & $15: 26: 57$ & $9 / 19$ & $15: 14: 48$ & $74.58 \mathrm{~m}, 41.21 \mathrm{~m},-1.50 \mathrm{~m}$ \\
& & & & $(75.36 \mathrm{~m}, 41.42 \mathrm{~m},-1.50 \mathrm{~m})$ \\
\hline $\begin{array}{l}60.5 \\
(61.5)\end{array}$ & $4 / 4$ & $15: 11: 16$ & $9 / 11$ & $15: 04: 13$ & $60.69 \mathrm{~m}, 36.87 \mathrm{~m},-1.50 \mathrm{~m}$ \\
& & & & & $(61.46 \mathrm{~m}, 37.13 \mathrm{~m},-1.50 \mathrm{~m})$ \\
\hline
\end{tabular}

\footnotetext{
${ }^{199}$ Vernal equinox in 9 BC according to NASA; see: http://data.giss.nasa.gov/ar5/srvernal.html

${ }^{200}$ Number in parentheses is estimate of meters from obelisk in the simulation without subsidence of the $29.6 \mathrm{~m}$ obelisk.

${ }^{201}$ Date in parentheses is best date of the second alignment in the year in the simulation without the subsidence of the $29.6 \mathrm{~m}$ obelisk.

${ }^{202}$ Coordinates in parentheses are those of the simulation without subsidence of the $29.6 \mathrm{~m}$ obelisk.

${ }^{203}$ Vernal equinox in 9 BC according to NASA; see: http://data.giss.nasa.gov/ar5/srvernal.html
} 
Appendix Table 3: Report on solar alignments over the Ara Pacis

Zone: 3

Software used: Stellarium

3d plug-ins: 3d Sceneries (a) Meridian Augusti revised (=29.6 m obelisk); (b) 30.7m Obelisk (used in stress tests)

Settings: View-Markings-Projection: Perspective.

Height of gnomon: $29.6 \mathrm{~m}$ (100 Roman feet)

Year investigated: 9 BC (“- 8 ” on Stellarium's clock)

Time: UTC

Alignment: center of the solar disk rising on axis over the Ara Pacis as seen by an observer looking toward the east.

Year: 9 BC

Observer: Bernard Frischer Date: 8/23/2015

Note 1. On the following table, the measurements in meters are approximate and are offered to give users a quick idea of where to move Stellarium's camera. The Grid Coordinates are exact.

Note 2: On the table, Date-1 and Time-1 give the times when the centers of the solar disk and west elevation of the Ara Pacis closely coincide. Date-2 and Time-2 give the equivalent dates later in the year. Usually, the centers do not coincide as closely on these latter dates. The slight difference is detectable at the small FOVs used for analytical purposes but not at the more realistic FOV of $90^{\circ}$ which approximates what the ancient observer will have seen.

Note 3: In the published version of the simulation, the user may go directly to the grid coordinates indicated on the table. To do so, open the Configuration Window (the wrench icon on the left side of the screen). Select Plugins and click "configure" in the bottom left. In the 3d Scenery window, click on "Load/save viewpoints." A list of stored viewpoints is displayed. Click on the date as per Date1 on the tale below. Stellarium moves the camera to the appropriate grid coordinates. Stellarium does not, however, change the date or time. Do this by click on the clock icon on the left side of the screen. Set the date to $-8\left(=9 \mathrm{BC}^{204}\right)$; and key in the appropriate month, day, hour, minute, and second, as per the table below.

Note 4: Since at present it is not possible to lock the camera onto a fixed path in Stellarium, the data that follows below are only approximately correct; moreover in the case of the alignments reported here, there was nothing like the obelisk's finial to determine the centering. We estimate they are accurate to $\pm 10.00 \mathrm{~m}$ and \pm 30 minutes. Since the point of the table is to show that, without doubt, there are many solar alignments in the area of the Ara Pacis and obelisk, we consider this degree of accuracy to be acceptable.

Appendix Table 3A

\begin{tabular}{|l|l|l|l|l|l|}
\hline $\begin{array}{c}\text { Meters from } \\
\text { west entrance } \\
\text { of Ara Pacis } \\
\text { (estimate) }\end{array}$ & Date-1 & \multicolumn{1}{|c|}{ Time-1 } & \multicolumn{1}{|c|}{ Date-2 } & \multicolumn{1}{c|}{ Gime-2 } & \\
\hline 90 & $4 / 30$ & $04: 23: 24$ & $8 / 18$ & $04: 29: 37$ & $1.43 \mathrm{~m}, 18.52 \mathrm{~m}, 0.08 \mathrm{~m}$ \\
\hline 85 & $5 / 1$ & $04: 24: 37$ & $8 / 17$ & $04: 32: 07$ & $7.74 \mathrm{~m}, 20.58 \mathrm{~m},-0.58 \mathrm{~m}$ \\
\hline 77 & $5 / 2$ & $04: 25: 15$ & $8 / 16$ & $04: 33: 15$ & $8.56 \mathrm{~m}, 20.85 \mathrm{~m},-1.02 \mathrm{~m}$ \\
\hline 75 & $5 / 3$ & $04: 25: 15$ & $8 / 15$ & $04: 34: 25$ & $9.48 \mathrm{~m}, 21.17 \mathrm{~m},-1.50 \mathrm{~m}$ \\
\hline 66 & $5 / 4$ & $04: 27: 09$ & $8 / 14$ & $04: 35: 28$ & $18.33 \mathrm{~m}, 23.68 \mathrm{~m},-1.50 \mathrm{~m}$ \\
\hline 60 & $5 / 5$ & $04: 28: 12$ & $8 / 13$ & $04: 37: 30$ & $24.81 \mathrm{~m}, 25.82 \mathrm{~m},-1.50 \mathrm{~m}$ \\
\hline
\end{tabular}

${ }^{204}$ Stellarium has $0 \mathrm{BC} / \mathrm{AD}$, a non-existent year. Hence, to get dates $\mathrm{BC}$, one must add a year. So, as in the present case, $9 \mathrm{BC}$ in Stellarium is Year -8 . 
The Relationship between the Montecitorio Obelisk and the Ara Pacis 1:95

\begin{tabular}{|c|c|c|c|c|c|}
\hline 55 & $5 / 6$ & $04: 29: 25$ & $8 / 12$ & $04: 38: 25$ & $30.83 m, 27.58 m,-1.50 m$ \\
\hline 50 & $5 / 7$ & $04: 30: 25$ & $8 / 11$ & 04:39:39 & $35.55 \mathrm{~m}, 29.13 \mathrm{~m},-1.50 \mathrm{~m}$ \\
\hline 46 & $5 / 8$ & 04:31:39 & $8 / 10$ & 04:40:55 & $39.26 \mathrm{~m}, 30.13 \mathrm{~m},-1.50 \mathrm{~m}$ \\
\hline 42 & $5 / 9$ & $04: 32: 55$ & $8 / 9$ & 04:42:49 & $43.14 \mathrm{~m}, 31.38 \mathrm{~m},-1.50 \mathrm{~m}$ \\
\hline 40 & $5 / 10$ & $04: 34: 49$ & $8 / 8$ & 04:44:37 & $46.63 \mathrm{~m}, 32.39 \mathrm{~m},-1.50 \mathrm{~m}$ \\
\hline 38 & $5 / 11$ & 04:36:00 & $8 / 7$ & $04: 45: 48$ & $49.21 \mathrm{~m}, 33.26 \mathrm{~m},-1.50 \mathrm{~m}$ \\
\hline 36 & $5 / 12$ & $04: 37: 48$ & $8 / 6$ & $04: 47: 37$ & $52.03 \mathrm{~m}, 34.22 \mathrm{~m},-1.50 \mathrm{~m}$ \\
\hline 34 & $5 / 13$ & 04:39:37 & $8 / 5$ & 04:49:32 & $54.53 \mathrm{~m}, 35.09 \mathrm{~m},-1.50 \mathrm{~m}$ \\
\hline 33 & $5 / 14$ & 04:40:32 & $8 / 4$ & 04:50:18 & $55.85 \mathrm{~m}, 35.35 \mathrm{~m},-1.50 \mathrm{~m}$ \\
\hline 31 & $5 / 15$ & $04: 43: 18$ & $8 / 3$ & 04:53:09 & $58.03 \mathrm{~m}, 36.08 \mathrm{~m},-1.50 \mathrm{~m}$ \\
\hline 30 & $5 / 16$ & $04: 43: 25$ & $8 / 2$ & 04:54:08 & $58.79 \mathrm{~m}, 36.19 \mathrm{~m},-1.50 \mathrm{~m}$ \\
\hline 29 & $5 / 17$ & $04: 43: 45$ & $8 / 1$ & 04:55:19 & $59.58 \mathrm{~m}, 36.47 \mathrm{~m},-1.50 \mathrm{~m}$ \\
\hline 28 & $5 / 18$ & 04:44:47 & $7 / 31$ & $04: 56: 14$ & $60.60 \mathrm{~m}, 36.84 \mathrm{~m},-1.50 \mathrm{~m}$ \\
\hline 27 & $5 / 19$ & $04: 45: 54$ & $7 / 30$ & $04: 57: 18$ & $61.49 \mathrm{~m}, 37.15 \mathrm{~m},-1.50 \mathrm{~m}$ \\
\hline 27 & $5 / 20$ & 04:46:18 & $7 / 29$ & 04:57:22 & $62.18 \mathrm{~m}, 37.28 \mathrm{~m},-1.50 \mathrm{~m}$ \\
\hline 26 & $5 / 21$ & 04:47:07 & $7 / 28$ & 04:57:49 & $62.97 \mathrm{~m}, 37.53 \mathrm{~m},-1.50 \mathrm{~m}$ \\
\hline 25 & $5 / 22$ & 04:48:30 & $7 / 27$ & $04: 58: 40$ & $63.75 \mathrm{~m}, 37.78 \mathrm{~m},-1.50 \mathrm{~m}$ \\
\hline 25 & $5 / 23$ & 04:49:49 & $7 / 26$ & 04:59:03 & $64.34 \mathrm{~m}, 37.97 \mathrm{~m},-1.50 \mathrm{~m}$ \\
\hline 25 & $5 / 24$ & 04:50:21 & $7 / 25$ & 05:00:11 & $65.07 \mathrm{~m}, 38.20 \mathrm{~m},-1.50 \mathrm{~m}$ \\
\hline 24 & $5 / 25$ & 04:51:11 & $7 / 24$ & 05:00:58 & $65.60 \mathrm{~m}, 38.37 \mathrm{~m},-1.50 \mathrm{~m}$ \\
\hline 24 & $5 / 26$ & 04:53:11 & $7 / 23$ & $05: 02: 25$ & $66.43 m, 38.63 m,-1.50 m$ \\
\hline 23 & $5 / 27$ & 04:54:59 & $7 / 22$ & 05:03:12 & $66.59 \mathrm{~m}, 38.70 \mathrm{~m},-1.50 \mathrm{~m}$ \\
\hline 23 & $5 / 28$ & $04: 53: 58$ & $7 / 21$ & 05:03:47 & $67.18 \mathrm{~m}, 38.87 \mathrm{~m},-1.50 \mathrm{~m}$ \\
\hline 23 & $5 / 29$ & $04: 54: 36$ & $7 / 20$ & 05:04:22 & $67.49 \mathrm{~m}, 38.96 \mathrm{~m},-1.50 \mathrm{~m}$ \\
\hline 23 & $5 / 30$ & $04: 55: 07$ & $7 / 19$ & $05: 04: 46$ & $67.66 \mathrm{~m}, 39.01 \mathrm{~m},-1.50 \mathrm{~m}$ \\
\hline 22 & $5 / 31$ & $04: 55: 20$ & $7 / 18$ & 05:05:05 & $67.72 \mathrm{~m}, 39.02 \mathrm{~m},-1.50 \mathrm{~m}$ \\
\hline 22 & $6 / 1$ & $04: 55: 32$ & $7 / 17$ & 05:05:20 & $67.91 \mathrm{~m}, 39.08 \mathrm{~m},-1.50 \mathrm{~m}$ \\
\hline 22 & $6 / 2$ & 04:56:14 & $7 / 16$ & 05:05:52 & $68.23 \mathrm{~m}, 39.16 \mathrm{~m},-1.50 \mathrm{~m}$ \\
\hline 21 & $6 / 3$ & $04: 57: 44$ & $7 / 15$ & 05:06:07 & $68.63 \mathrm{~m}, 39.28 \mathrm{~m},-1.50 \mathrm{~m}$ \\
\hline 21 & $6 / 4$ & 04:58:21 & $7 / 14$ & 05:06:11 & $68.93 \mathrm{~m}, 39.37 \mathrm{~m},-1.50 \mathrm{~m}$ \\
\hline 21 & $6 / 5$ & 04:59:11 & $7 / 13$ & 05:06:22 & $69.25 \mathrm{~m}, 39.48 \mathrm{~m},-1.50 \mathrm{~m}$ \\
\hline 20 & $6 / 6$ & 05:00:04 & $7 / 12$ & 05:06:30 & $69.45 \mathrm{~m}, 39.54 \mathrm{~m},-1.50 \mathrm{~m}$ \\
\hline 20 & $6 / 7$ & 05:00:29 & $7 / 11$ & $05: 07: 15$ & $69.81 \mathrm{~m}, 39.67 \mathrm{~m},-1.50 \mathrm{~m}$ \\
\hline 20 & $6 / 8$ & 05:01:00 & $7 / 10$ & $05: 07: 25$ & $70.02 \mathrm{~m}, 39.74 \mathrm{~m},-1.50 \mathrm{~m}$ \\
\hline 20 & $6 / 9$ & $05: 01: 25$ & $7 / 9$ & 05:07:37 & $70.11 \mathrm{~m}, 39.77 \mathrm{~m},-1.50 \mathrm{~m}$ \\
\hline 20 & $6 / 10$ & 05:01:55 & $7 / 8$ & 05:07:47 & $70.31 \mathrm{~m}, 39.84 \mathrm{~m},-1.50 \mathrm{~m}$ \\
\hline 20 & $6 / 11$ & 05:02:30 & $7 / 7$ & $05: 08: 15$ & $70.46 \mathrm{~m}, 39.89 \mathrm{~m},-1.50 \mathrm{~m}$ \\
\hline
\end{tabular}




\begin{tabular}{|l|l|l|l|l|l|}
\hline 19 & $6 / 12$ & $05: 02: 58$ & $7 / 6$ & $05: 08: 35$ & $70.59 \mathrm{~m}, 39.93 \mathrm{~m},-1.50 \mathrm{~m}$ \\
\hline 19 & $6 / 13$ & $05: 03: 35$ & $7 / 5$ & $05: 08: 42$ & $70.75 \mathrm{~m}, 39.98 \mathrm{~m},-1.50 \mathrm{~m}$ \\
\hline 19 & $6 / 14$ & $05: 04: 00$ & $7 / 4$ & $05: 08: 53$ & $70.87 \mathrm{~m}, 40.02 \mathrm{~m},-1.50 \mathrm{~m}$ \\
\hline 19 & $6 / 15$ & $05: 04: 33$ & $7 / 3$ & $05: 09: 05$ & $70.93 \mathrm{~m}, 40.04 \mathrm{~m},-1.50 \mathrm{~m}$ \\
\hline 18 & $6 / 16$ & $05: 05: 02$ & $7 / 2$ & $05: 08: 31$ & $71.11 \mathrm{~m}, 40.10 \mathrm{~m},-1.50 \mathrm{~m}$ \\
\hline 18 & $6 / 17$ & $05: 05: 30$ & $7 / 1$ & $05: 08: 41$ & $71.26 \mathrm{~m}, 40.02 \mathrm{~m},-1.50 \mathrm{~m}$ \\
\hline 18 & $6 / 18$ & $05: 05: 43$ & $6 / 30$ & $05: 08: 49$ & $71.32 \mathrm{~m}, 40.04 \mathrm{~m},-1.50 \mathrm{~m}$ \\
\hline 18 & $6 / 19$ & $05: 06: 34$ & $6 / 29$ & $05: 08: 54$ & $71.40 \mathrm{~m}, 40.07 \mathrm{~m},-1.50 \mathrm{~m}$ \\
\hline 18 & $6 / 20$ & $05: 07: 07$ & $6 / 28$ & $05: 09: 00$ & $71.47 \mathrm{~m}, 40.21 \mathrm{~m},-1.50 \mathrm{~m}$ \\
\hline 18 & $6 / 21$ & $05: 07: 34$ & $6 / 27$ & $05: 08: 46$ & $71.52 \mathrm{~m}, 40.23 \mathrm{~m},-1.50 \mathrm{~m}$ \\
\hline & $6 / 22$ & $05: 08: 26$ & $6 / 26$ & $05: 09: 08$ & $71.63 \mathrm{~m}, 40.26 \mathrm{~m},-1.50 \mathrm{~m}$ \\
\hline & $6 / 23$ & $05: 08: 43$ & $6 / 25$ & $05: 08: 43$ & $71.69 \mathrm{~m}, 40.28 \mathrm{~m},-1.50 \mathrm{~m}$ \\
\hline & $6 / 24$ & $05: 09: 13$ & --- & & $71.74 \mathrm{~m}, 40.29 \mathrm{~m},-1.50 \mathrm{~m}$ \\
\hline
\end{tabular}

Appendix Table 3B. Observations in years 1, 2, and 3 of the four-year leap-year cycle for a random sample of alignments listed on Table A.

\begin{tabular}{|c|c|c|c|c|c|}
\hline Year in cycle & Date-1 & Time-1 & Date-2 & Time-2 & Grid Coordinates $^{205}$ \\
\hline 1 & $5 / 4$ & 04:27:09 & $8 / 14$ & $04: 35: 28$ & $18.33 \mathrm{~m}, 23.68 \mathrm{~m},-1.50 \mathrm{~m}$ \\
\hline 2 & $5 / 4$ & 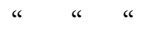 & $8 / 14$ & 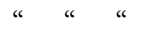 & 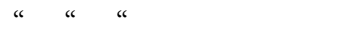 \\
\hline 3 & $5 / 4$ & “ $\quad$ " & $8 / 14$ & “ $\quad$ “ $\quad$ " & 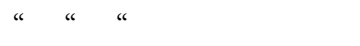 \\
\hline 1 & $5 / 7$ & $4: 30: 25$ & $8 / 11$ & 04:39:39 & $35.55 \mathrm{~m}, 29.13 \mathrm{~m},-1.50 \mathrm{~m}$ \\
\hline 2 & $5 / 7$ & " $\quad$ " $\quad$ & $8 / 11$ & " $\quad$ " $\quad$ " & 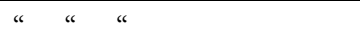 \\
\hline 3 & $5 / 7$ & 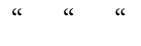 & $8 / 11$ & 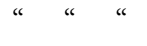 & “ $"$ " \\
\hline 1 & $5 / 13$ & $04: 39: 30$ & $8 / 5$ & $04: 49: 32$ & $54.53 \mathrm{~m}, 35.09 \mathrm{~m},-1.50 \mathrm{~m}$ \\
\hline 2 & $5 / 13$ & 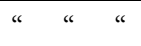 & $8 / 5$ & “ $" ~$ & “ “ \\
\hline 3 & $5 / 13$ & " $\quad$ " & $8 / 5$ & “ “ & " $\quad$ " \\
\hline
\end{tabular}

\footnotetext{
205 The grid coordinates are always those best for the Date-1 alignment.
} 
Appendix Table 4: Report on solar alignments east of Ara Pacis

Zone: 4

Software used: Stellarium

3d plug-ins: 3d Sceneries (a) Meridian Augusti revised (=29.6 m obelisk); (b) 30.7m Obelisk (used in stress tests)

Settings: View-Markings-Projection: Perspective.

Height of gnomon: 29.6 m (100 Roman feet)

Year investigated: 9 BC (“- 8 ” on Stellarium's clock)

Time: UTC

Alignment: obelisk's finial centered on sun's disk

Year: 9 BC

Observer: Bernard Frischer

Date: $8 / 12 / 2015$

Note 1: Observations arbitrarily stopped at 196 meters east of Ara Pacis. As far as is known, no other building occupied this area in Augustan Rome.

Note 2. On the following table, the measurements in meters are approximate and are offered to give users a quick idea of where to move Stellarium's camera. The Grid Coordinates are exact.

Note 3: On the table, Date-1 and Time-1 give the times when the centers of the finial and solar disk closely coincide. Date-2 and Time2 give the equivalent dates later in the year. Usually, the centers do not coincide as closely on these latter dates. The slight difference is detectable at the small FOVs used for analytical purposes but not at the more realistic FOV of $90^{\circ}$ which approximates what the ancient observer will have seen.

Note 4: In the published version of the simulation, the user may go directly to the grid coordinates indicated on the table. To do so, open the Configuration Window (the wrench icon on the left side of the screen). Select Plugins and click "configure" in the bottom left. In the 3d Scenery window, click on "Load/save viewpoints." A list of stored viewpoints is displayed. Click on the date as per Date1 on the tale below. Stellarium moves the camera to the appropriate grid coordinates. Stellarium does not, however, change the date or time. Do this by click on the clock icon on the left side of the screen. Set the date to $-8\left(=9 \mathrm{BC}^{206}\right)$; and key in the appropriate month, day, hour, minute, and second, as per the table below.

Note 5: Since at present it is not possible to lock the camera onto a fixed path in Stellarium, the data that follows below are only approximately correct. We estimate they are accurate to $\pm 10.00 \mathrm{~m}$ and \pm 30 minutes. Since the point of the table is to show that, without doubt, there are many solar alignments in the area of the Ara Pacis and obelisk, we consider this degree of accuracy to be acceptable.

Note 6: Table B presents the results using the Stellarium model with an obelisk that is $30.7 \mathrm{~m}$ and moved $1 \mathrm{~m}$ south along the extension of the meridian line. It presents the first three and last three pairs of dates on Table A.

\section{Appendix Table 4A}

\begin{tabular}{|l|l|l|l|l|l|}
\hline $\begin{array}{c}\text { Meters from } \\
\text { east entrance of } \\
\text { Ara Pacis } \\
\text { (estimate) }\end{array}$ & Date-1 & Time-1 & Date-2 & Time-2 & \multicolumn{1}{c|}{ Grid Coordinates } \\
\hline 16 & $10 / 3$ & $15: 35: 02$ & $3 / 13$ & $15: 55: 40$ & $117.08 \mathrm{~m}, 54.11 \mathrm{~m},-0.22 \mathrm{~m}$ \\
\hline 24 & $10 / 4$ & $15: 36: 09$ & $3 / 12$ & $15: 57: 24$ & $121.93 \mathrm{~m}, 55.63 \mathrm{~m},-0.22 \mathrm{~m}$ \\
\hline 29 & $10 / 5$ & $15: 37: 11$ & $3 / 11$ & $15: 59: 08$ & $127.01 \mathrm{~m}, 57.31 \mathrm{~m},-0.22 \mathrm{~m}$ \\
\hline
\end{tabular}

${ }^{206}$ Stellarium has $0 \mathrm{BC} / \mathrm{AD}$, a non-existent year. Hence, to get dates $\mathrm{BC}$, one must add a year. So, as in the present case, $9 \mathrm{BC}$ in Stellarium is Year -8 . 


\begin{tabular}{|l|l|l|l|l|l|}
\hline 35 & $10 / 6$ & $15: 38: 51$ & $3 / 10$ & $16: 01: 04$ & $133.33 \mathrm{~m}, 59.26 \mathrm{~m},-0.22 \mathrm{~m}$ \\
\hline 43 & $10 / 7$ & $15: 40: 22$ & $3 / 9$ & $16: 03: 02$ & $141.02 \mathrm{~m}, 61.56 \mathrm{~m},-0.22 \mathrm{~m}$ \\
\hline 50 & $10 / 8$ & $15: 41: 44$ & $3 / 8$ & $16: 04: 53$ & $148.84 \mathrm{~m}, 63.99 \mathrm{~m},-0.22 \mathrm{~m}$ \\
\hline 59 & $10 / 9$ & $15: 43: 04$ & $3 / 7$ & $16: 06: 43$ & $157.17 \mathrm{~m}, 66.59 \mathrm{~m},-0.22 \mathrm{~m}$ \\
\hline 68 & $10 / 10$ & $15: 44: 31$ & $3 / 6$ & $16: 08: 40$ & $166.26 \mathrm{~m}, 69.34 \mathrm{~m},-0.22 \mathrm{~m}$ \\
\hline 79 & $10 / 11$ & $15: 45: 52$ & $3 / 5$ & $16: 10: 30$ & $176.91 \mathrm{~m}, 72.66 \mathrm{~m},-0.22 \mathrm{~m}$ \\
\hline 91 & $10 / 12$ & $15: 47: 19$ & $3 / 4$ & $16: 12: 19$ & $188.75 \mathrm{~m}, 76.32 \mathrm{~m},-0.22 \mathrm{~m}$ \\
\hline 104 & $10 / 13$ & $15: 48: 44$ & $3 / 3$ & $16: 14: 11$ & $202.28 \mathrm{~m}, 80.52 \mathrm{~m},-0.22 \mathrm{~m}$ \\
\hline 118 & $10 / 14$ & $15: 50: 09$ & $3 / 2$ & $16: 16: 03$ & $218.02 \mathrm{~m}, 85.29 \mathrm{~m},-0.22 \mathrm{~m}$ \\
\hline 138 & $10 / 15$ & $15: 51: 35$ & $3 / 1$ & $16: 17: 51$ & $236.24 \mathrm{~m}, 90.93 \mathrm{~m},-0.22 \mathrm{~m}$ \\
\hline 165 & $10 / 16$ & $15: 52: 58$ & $2 / 29^{207}$ & $16: 19: 38$ & $256.40 \mathrm{~m}, 97.15 \mathrm{~m},-0.22 \mathrm{~m}$ \\
\hline 190 & $10 / 17$ & $15: 54: 21$ & $2 / 28$ & $16: 21: 28$ & $280.72 \mathrm{~m}, 104.61 \mathrm{~m},-0.22 \mathrm{~m}$ \\
\hline
\end{tabular}

Appendix Table 4B. Observations in years 1,2, and 3 of the four-year leap-year cycle for a random sample of alignments listed on Table A.

\begin{tabular}{|c|c|c|c|c|c|}
\hline Year in cycle & Date-1 & Time-1 & Date-2 & Time-2 & Grid Coordinates ${ }^{208}$ \\
\hline 1 & $10 / 5$ & $15: 37: 11$ & $3 / 11$ & $15: 59: 08$ & $127.01 \mathrm{~m}, 57.31 \mathrm{~m},-0.22 \mathrm{~m}$ \\
\hline 2 & “ « & $15: 37: 06$ & “ “ & $15: 59: 24$ & $126.20 \mathrm{~m}, 57.07 \mathrm{~m},-0.22 \mathrm{~m}$ \\
\hline 3 & “ “ & $15: 36: 42$ & $3 / 12^{209}$ & $15: 58: 01$ & $124.47 \mathrm{~m}, 56.56 \mathrm{~m},-0.22 \mathrm{~m}$ \\
\hline 1 & $10 / 9$ & $15: 43: 04$ & $3 / 7$ & $16: 06: 43$ & $157.17 \mathrm{~m}, 66.59 \mathrm{~m},-0.22 \mathrm{~m}$ \\
\hline 2 & " " & $15: 42: 41$ & “ “ & $16: 07: 04$ & $154.85 \mathrm{~m}, 65.91 \mathrm{~m},-0.22 \mathrm{~m}$ \\
\hline 3 & “ “ & $15: 42: 15$ & $3 / 8^{2}$ & $16: 05: 39$ & $152.30 \mathrm{~m}, 65.15 \mathrm{~m},-0.22 \mathrm{~m}$ \\
\hline 1 & $10 / 14$ & $15: 50: 09$ & $3 / 2$ & $16: 16: 03$ & $218.02 \mathrm{~m}, 85.29 \mathrm{~m},-0.22 \mathrm{~m}$ \\
\hline 2 & “ “ & $15: 49: 46$ & “ “ & $16: 16: 28$ & $212.60 \mathrm{~m}, 83.67 \mathrm{~m},-0.22 \mathrm{~m}$ \\
\hline 3 & " " & $15: 49: 23$ & " " & $16: 16: 48$ & $209.54 \mathrm{~m}, 82.75 \mathrm{~m},-0.22 \mathrm{~m}$ \\
\hline
\end{tabular}

\footnotetext{
${ }^{207}$ This is a hypothetical date since in this year the leap year was suppressed.

${ }^{208}$ The grid coordinates are always those best for the Date-1 alignment.

${ }^{209}$ Note the shift of one day.
} 
The Relationship between the Montecitorio Obelisk and the Ara Pacis 1:99

Appendix Table 4C: Stress tests with 30.7 m obelisk

\begin{tabular}{|l|l|l|l|l|l|}
\hline $\begin{array}{c}\text { Meters from } \\
\text { east entrance of } \\
\begin{array}{c}\text { Ara Pacis } \\
\text { (estimate) }\end{array}\end{array}$ & Date-1 & \multicolumn{1}{|c|}{ Time-1 } & \multicolumn{1}{|c|}{ Date-2 } & \multicolumn{1}{c|}{ Time-2 } & \multicolumn{1}{c|}{ Grid Coordinates } \\
\hline 15 & $10 / 3$ & $15: 31: 54$ & $3 / 13$ & $15: 52: 30$ & $116.08 \mathrm{~m}, 54.01 \mathrm{~m},-0.22 \mathrm{~m}$ \\
\hline 20 & $10 / 4$ & $15: 34: 03$ & $3 / 12$ & $15: 54: 25$ & $121.26 \mathrm{~m}, 55.69 \mathrm{~m},-0.22 \mathrm{~m}$ \\
\hline 25 & $10 / 5$ & $15: 34: 27$ & $3 / 11$ & $15: 56: 13$ & $126.60 \mathrm{~m}, 57.42 \mathrm{~m},-0.22 \mathrm{~m}$ \\
\hline 94 & $10 / 13$ & $15: 45: 36$ & $3 / 3$ & $16: 11: 08$ & $195.31 \mathrm{~m}, 79.31 \mathrm{~m},-0.22 \mathrm{~m}$ \\
\hline 114 & $10 / 14$ & $15: 47: 09$ & $3 / 2$ & $16: 13: 04$ & $209.66 \mathrm{~m}, 83.93 \mathrm{~m},-0.22 \mathrm{~m}$ \\
\hline 130 & $10 / 15$ & $15: 48: 34$ & $3 / 1$ & $16: 14: 52$ & $225.82 \mathrm{~m}, 88.97 \mathrm{~m},-0.22 \mathrm{~m}$ \\
\hline
\end{tabular}

Appendix Table 4D. Stress tests of $29.6 \mathrm{~m}$ obelisk with $5 \mathrm{~cm}$ of subsidence to the southwest

Year: 9 BC

Method: three randomly chosen dates from Appendix Table 3A were tested to see if the dates of alignment would be changed or invalidated after the $29.6 \mathrm{~m}$ obelisk had subsided $5 \mathrm{~cm}$.

\begin{tabular}{|c|c|c|c|c|c|}
\hline $\begin{array}{c}\text { Meters from obelisk } \\
\text { (estimate) }^{210} \\
\end{array}$ & Date-1 & Time-1 & Date-2211 & Time-2 & Grid Coordinates $^{212}$ \\
\hline $\begin{array}{l}21 \\
(21)\end{array}$ & $10 / 4$ & $15: 35: 52$ & $3 / 12$ & $15: 56: 58$ & $\begin{array}{l}121.21 \mathrm{~m}, 55.37 \mathrm{~m},-0.22 \mathrm{~m} \\
(121.93 \mathrm{~m}, 55.63 \mathrm{~m},-0.22 \mathrm{~m})\end{array}$ \\
\hline $\begin{array}{l}46 \\
(47)\end{array}$ & $10 / 8$ & $15: 41: 17$ & $3 / 8$ & $16: 04: 31$ & $\begin{array}{l}147.10 \mathrm{~m}, 63.42 \mathrm{~m},-0.22 \mathrm{~m} \\
(148.84 \mathrm{~m}, 63.99 \mathrm{~m},-0.22 \mathrm{~m})\end{array}$ \\
\hline $\begin{array}{l}99 \\
(101)\end{array}$ & $10 / 13$ & $15: 48: 22$ & $3 / 3$ & $16: 13: 45$ & $\begin{array}{l}200.44 \mathrm{~m}, 79.91 \mathrm{~m},-0.22 \mathrm{~m} \\
(202.28 \mathrm{~m}, 80.52 \mathrm{~m},-0.22 \mathrm{~m})\end{array}$ \\
\hline
\end{tabular}

\footnotetext{
${ }^{210}$ Number in parentheses is estimated of meters from obelisk in the simulation without subsidence of the $29.6 \mathrm{~m}$ obelisk.

${ }^{211}$ Date in parentheses is best date of the second alignment in the year in the simulation without the subsidence of the $29.6 \mathrm{~m}$ obelisk.

${ }^{212}$ Coordinates in parentheses are those of the simulation without subsidence of the $29.6 \mathrm{~m}$ obelisk.
} 
Appendix Table 5: Report on observations of shadow striking axis of façade of Ara Pacis

Date: 9 BC

Time: UTC

Software: Unity

Observer: Bernard Frischer Date: August 10,2015

Note 1: These alignments are all interpositional: the best observations of the shadow projected onto the west façade of the Ara Pacis are seen by someone standing with his back to the obelisk positioned somewhere between the obelisk and the western staircase of the Ara Pacis. No positional data are reported (in contrast to Appendix tables 1-3) because it does not matter where you stand between the obelisk and the front steps of the Ara Pacis.

Note 2: There are dates (such as March 22) when the obelisk's shadow falls onto the western staircase of the Ara Pacis. These dates are not included on the table.

Appendix Table 5A: Dates and times of shadow alignments

\begin{tabular}{|c|c|c|}
\hline Date and time-1 & Date and time- 2 & Description of shadow \\
\hline Feb. 25, 16:28 & October $21,16: 01$ & $\begin{array}{l}\text { shadow of the trunk of the obelisk } \\
\text { reaches the altar inside the Ara Pacis }\end{array}$ \\
\hline Feb. 26, 16:26 & October 20, 16:00 & “ “ \\
\hline Feb. $27,16: 25$ & October $19,15: 58$ & “ “ \\
\hline Feb. 28, 16:23 & October 18, 15:56 & “ “ \\
\hline March 1, 16:19 & October $17,15: 54$ & “ “ \\
\hline March 2, 517 & October $16,15: 53$ & “ “ \\
\hline March 3, 16:15 & October $15,15: 52$ & “ “ \\
\hline March 4, 16:13 & October $14,15: 50$ & “ “ \\
\hline March 5, 16:12 & October 13, 15:49 & “ “ \\
\hline March 6, 16:10 & October $12,15: 48$ & “ $"$ \\
\hline March 7, 16:08 & October 11, 15:46 & “ “ \\
\hline March 8, 16:06 & October 10, 15:45 & “ “ \\
\hline March 9, 16:04 & October $9,15: 43$ & “ “ \\
\hline March 10, 16:02 & October 8, 15:42 & “ “ \\
\hline March 11, 16:00 & October $7,15: 40$ & “ $"$ \\
\hline March 12, 15:58 & October 6, 15:39 & $\begin{array}{l}\text { shadow of the pyramidion reaches the } \\
\text { altar inside the Ara Pacis }\end{array}$ \\
\hline March 13, 15:56 & October $5,15: 38$ & “ $"$ \\
\hline March 14, 15:54 & October 4, 15:36 & “ $"$ \\
\hline March 15, 15:52 & October 3, 15:35 & $\begin{array}{l}\text { shadow of the pyramidion over the } \\
\text { western doorway, the trunk of the } \\
\text { obelisk over the altar inside the Ara } \\
\text { Pacis }\end{array}$ \\
\hline
\end{tabular}




\begin{tabular}{|l|l|l|}
\hline March 16, 15:50 & October 2, 15:34 & $\begin{array}{l}\text { shadow of the pyramidion over the } \\
\text { lintel of the western doorway, the } \\
\text { trunk of the obelisk reaches the steps } \\
\text { to the altar inside the Ara Pacis }\end{array}$ \\
\hline March 17, 15:48 & October 1, 15:33 & $\begin{array}{l}\text { shadow of the pyramidion over the } \\
\text { steps and lower part of the altar inside } \\
\text { the Ara Pacis }\end{array}$ \\
\hline March 18, 15:46 & September 30,15:31 & " " \\
\hline March 19, 15:45 & September 29, 15:30 & $\begin{array}{l}\text { shadow of the pyramidion over the } \\
\text { steps of the altar inside the Ara Pacis }\end{array}$ \\
\hline March 20, 15:45 & September 28, 15:28 " \\
\hline March 21, 15:45 & September 27, 15:27 & $\begin{array}{l}\text { shadow over the threshold to the } \\
\text { interior of the Ara Pacis }\end{array}$ \\
\hline
\end{tabular}

Appendix Table 5B: Observations in years 2 and 3 of the four-year leap-year cycle for a random sample of alignments listed on Table A.

\begin{tabular}{|c|c|c|c|}
\hline $\begin{array}{c}\text { Year in } \\
\text { cycle }\end{array}$ & Date and time-1 & Date and time-2 & Description of shadow \\
\hline 1 & Feb. 25, 16:26 & October 21, 16:01 & $\begin{array}{l}\text { shadow of the trunk of the obelisk reaches the altar } \\
\text { inside the Ara Pacis }\end{array}$ \\
\hline 2 & " $\quad$ " $"$ & " & " $\quad$ " $\quad$ l \\
\hline 3 & 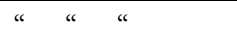 & 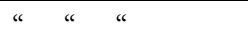 & “ “ " \\
\hline 1 & March 1, 16:18 & October $17,15: 54$ & 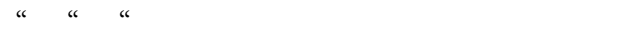 \\
\hline 2 & 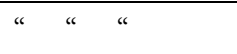 & “ $\quad$ " & 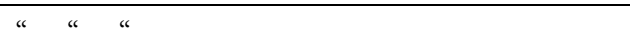 \\
\hline 3 & “ « " & “ « « & “ “ " \\
\hline 1 & March 6, 16:09 & October $12,15: 47$ & “ “ “ \\
\hline 2 & “ « " & 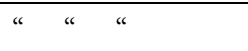 & 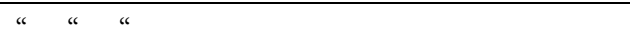 \\
\hline 3 & 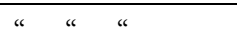 & $\begin{array}{lll} & \text { " }\end{array}$ & " \\
\hline
\end{tabular}

Appendix Table 5C.1: Stress test of the shadow alignments (30.7 m obelisk)

\begin{tabular}{|l|l|l|}
\hline \multicolumn{1}{|c|}{ Date and time-1 } & \multicolumn{1}{|c|}{ Date and time-2 } & \multicolumn{1}{c|}{ Description of shadow } \\
\hline Feb. 25, 16:23;42 & October 21, 15:57:06 & $\begin{array}{l}\text { shadow of the trunk of the obelisk } \\
\text { reaches the altar inside the Ara Pacis }\end{array}$ \\
\hline Feb. 26, 16:22:06 & October 20, 15:55:45 & “ “ \\
\hline Feb. 27, 16:20:15 & October 19, 15:54:08 “ \\
\hline March 19, 15:40:08 & & $\begin{array}{l}\text { shadow of the pyramidion on west } \\
\text { threshold of the Ara Pacis }\end{array}$ \\
\hline & September 29, 15:26:18 & $\begin{array}{l}\text { Shadow of pyramidion on steps of } \\
\text { interior altar }\end{array}$ \\
\hline
\end{tabular}




\begin{tabular}{|l|l|l|}
\hline March 20, 15:45 & & $\begin{array}{l}\text { Test failed: pyramidion on west } \\
\text { staircase (not in Ara Pacis) }\end{array}$ \\
\hline March 21, 15:45 & September 28, 15:28 & $\begin{array}{l}\text { Shadow of pyramdion on west } \\
\text { threshold of Ara Pacis }\end{array}$ \\
\hline & September 27, 15:27 & $\begin{array}{l}\text { Test failed: pyramidion on west } \\
\text { staircast (not in Ara Pacis) }\end{array}$ \\
\hline
\end{tabular}

Appendix Table 5C.2. Dates and times of shadow alignments with the $30.7 \mathrm{~m}$ obelisk that are not observed with the $29.6 \mathrm{~m}$ obelisk

\begin{tabular}{|l|l|l|}
\hline \multicolumn{1}{|c|}{ Date and time-1 } & \multicolumn{1}{|c|}{ Date and time-2 } & \multicolumn{1}{c|}{ Description of shadow } \\
\hline February 17, 16:37:21 & -- & $\begin{array}{l}\text { Shadow of trunk of obelisk covers } \\
\text { interior altar }\end{array}$ \\
\hline February 18, 16:35:25 & October 28, 16:08:02 & " “ \\
\hline February 19, 16:33:47 & October 27, 16:06:00 & “ “ \\
\hline February 20, 16:32:35 & October 26, 16:04:45 & " “ \\
\hline February 21, 16:30:35 & October 25, 16:03:14 & " “ \\
\hline February 22, 16:28:56 & October 24, 16:01:45 “ \\
\hline February 23, 16:27:15 & October 23, 16:00:10 & " “ \\
\hline February 24, 16:25:21 & October, 22, 15:58:38 & " “ \\
\hline
\end{tabular}

Appendix Table 5D: Stress tests of $29.6 \mathrm{~m}$ obelisk with $5 \mathrm{~cm}$ of subsidence to the southwest. Dates and times of shadow alignments.

Year: 9 BC

Method: three randomly chosen dates from Appendix Table $4 \mathrm{~A}$ were tested to see if the dates of alignment would be changed or invalidated after the $29.6 \mathrm{~m}$ obelisk had subsided $5 \mathrm{~cm}$.

\begin{tabular}{|l|l|l|}
\hline \multicolumn{1}{|c|}{ Date and time-1213 } & \multicolumn{1}{|c|}{ Date and time-2 ${ }^{214}$} & \multicolumn{1}{c|}{ Description of shadow } \\
\hline $\begin{array}{l}\text { Feb. 25, 16:27:04 } \\
(16: 28)\end{array}$ & $\begin{array}{l}\text { October 21, 16:01 } \\
(16: 01)\end{array}$ & $\begin{array}{l}\text { shadow of the trunk of the obelisk } \\
\text { reaches the altar inside the Ara Pacis }\end{array}$ \\
\hline March 11, 15:59:19 & $\begin{array}{l}\text { October 7, 15:40:19 } \\
(15: 40)\end{array}$ & \\
\hline March 19:00) $15: 43: 35$ & $\begin{array}{l}\text { September 29, } \\
(15: 30)\end{array}$ & $\begin{array}{l}\text { shadow of the pyramidion over the } \\
\text { steps of the altar inside the Ara Pacis }\end{array}$ \\
\hline
\end{tabular}

${ }^{213}$ The number in parentheses is the corresponding value from Appendix Table 4A.

${ }^{214}$ The number in parentheses is the corresponding value from Appendix Table 4A. 
The Relationship between the Montecitorio Obelisk and the Ara Pacis 1:103

Appendix Table 6: Overview of alignments by date, type, and zone

Note: This table aggregates the data on Appendix tables 1A-5A and shows the days on which there is either a solar or shadow alignment in the area studied.

\begin{tabular}{|c|c|c|c|c|c|c|}
\hline \multirow[t]{2}{*}{ Month } & \multirow[t]{2}{*}{ Day } & \multicolumn{4}{|c|}{ Solar alignment } & \multirow{2}{*}{$\begin{array}{c}\text { Shadow } \\
\text { alignment } \\
\text { Table } 5\end{array}$} \\
\hline & & $\begin{array}{l}\text { Zone } 1 \\
\text { Table } 1\end{array}$ & $\begin{array}{l}\text { Zone } 2 \\
\text { Table } 2\end{array}$ & $\begin{array}{l}\text { Zone } 3 \\
\text { Table } 3\end{array}$ & $\begin{array}{l}\text { Zone } 4 \\
\text { Table } 4\end{array}$ & \\
\hline \multirow[t]{5}{*}{ February } & 25 & & & & & $\mathrm{x}$ \\
\hline & 26 & & & & & $\mathrm{x}$ \\
\hline & 27 & & & & $\mathrm{x}$ & $\mathrm{x}$ \\
\hline & 28 & & & & $\mathrm{x}$ & $\mathrm{x}$ \\
\hline & (29) & & & & $\mathrm{x}$ & $\mathrm{x}$ \\
\hline \multirow[t]{29}{*}{ March } & 1 & & & & $\mathrm{x}$ & $\mathrm{x}$ \\
\hline & 2 & & & & $x$ & $\mathrm{x}$ \\
\hline & 3 & & & & $\mathrm{x}$ & $\mathrm{x}$ \\
\hline & 4 & & & & $x$ & $\mathrm{x}$ \\
\hline & 5 & & & & $\mathrm{x}$ & $\mathrm{x}$ \\
\hline & 6 & & & & $\mathrm{x}$ & $\mathrm{x}$ \\
\hline & 7 & & & & $x$ & $\mathrm{x}$ \\
\hline & 8 & & & & $\mathrm{x}$ & $\mathrm{x}$ \\
\hline & 9 & & & & $x$ & $\mathrm{x}$ \\
\hline & 10 & & & & $x$ & $\mathrm{x}$ \\
\hline & 11 & & & & $\mathrm{x}$ & $\mathrm{x}$ \\
\hline & 12 & & & & $\mathrm{x}$ & $\mathrm{x}$ \\
\hline & 13 & & & & $\mathrm{x}$ & $\mathrm{x}$ \\
\hline & 14 & & & & & $\mathrm{x}$ \\
\hline & 15 & & & & & $\mathrm{x}$ \\
\hline & 16 & & & & & $\mathrm{x}$ \\
\hline & 17 & & & & & $\mathrm{x}$ \\
\hline & 18 & & & & & $\mathrm{x}$ \\
\hline & 19 & & $\mathrm{x}$ & & & $\mathrm{x}$ \\
\hline & 20 & & $\mathrm{x}$ & & & $\mathrm{x}$ \\
\hline & 21 & & $\mathrm{x}$ & & & $\mathrm{x}$ \\
\hline & 22 & & $\mathrm{x}$ & & & \\
\hline & 23 & & $\mathrm{x}$ & & & \\
\hline & 24 & & $\mathrm{x}$ & & & \\
\hline & 25 & & $\mathrm{x}$ & & & \\
\hline & 26 & & $\mathrm{x}$ & & & \\
\hline & 27 & & $\mathrm{x}$ & & & \\
\hline & 28 & & $\mathrm{x}$ & & & \\
\hline & 29 & & $\mathrm{x}$ & & & \\
\hline
\end{tabular}

Studies in Digital Heritage, Vol. 1, No. 1, Article 2, Publication date: March 2017 


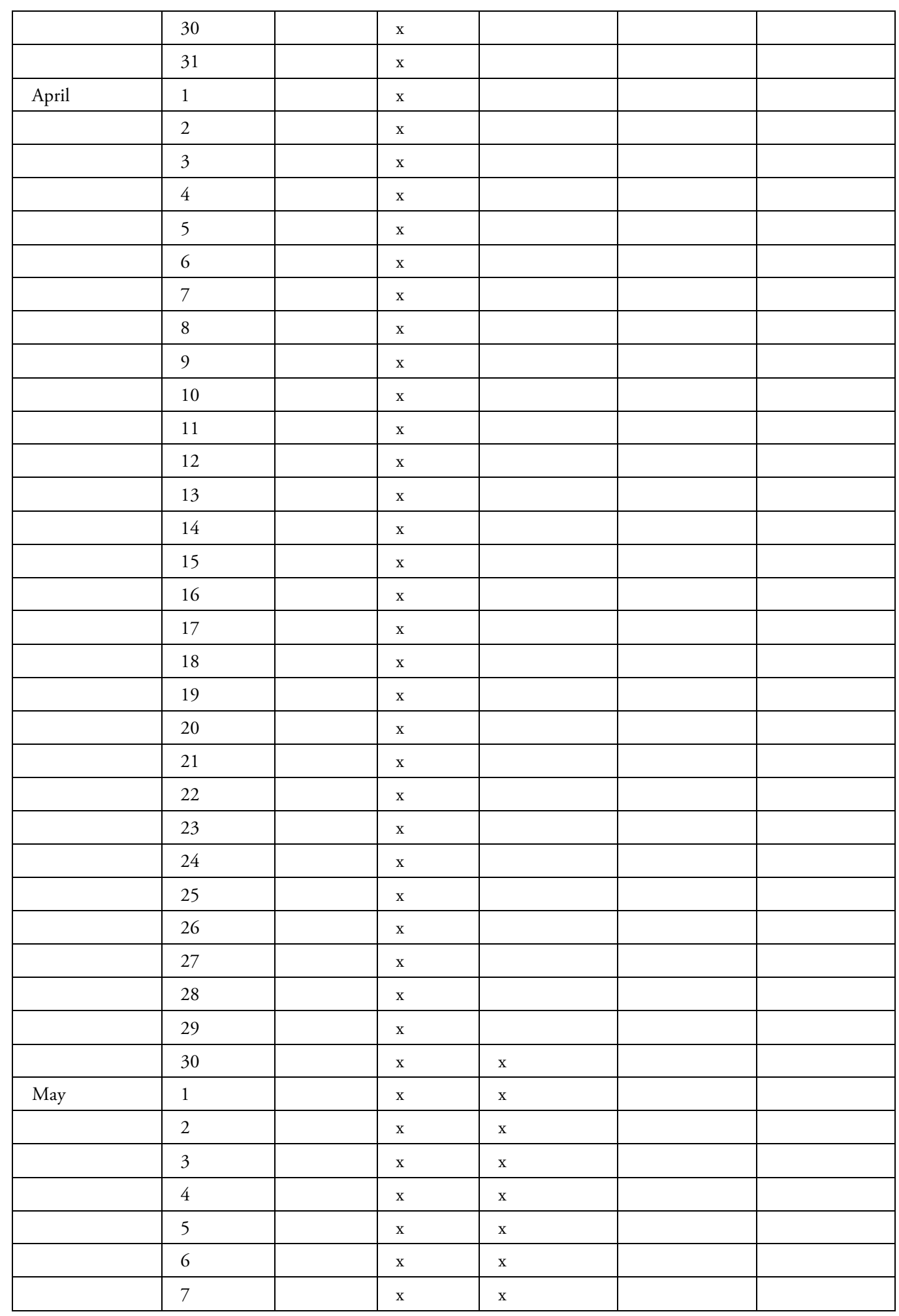


The Relationship between the Montecitorio Obelisk and the Ara Pacis 1:105

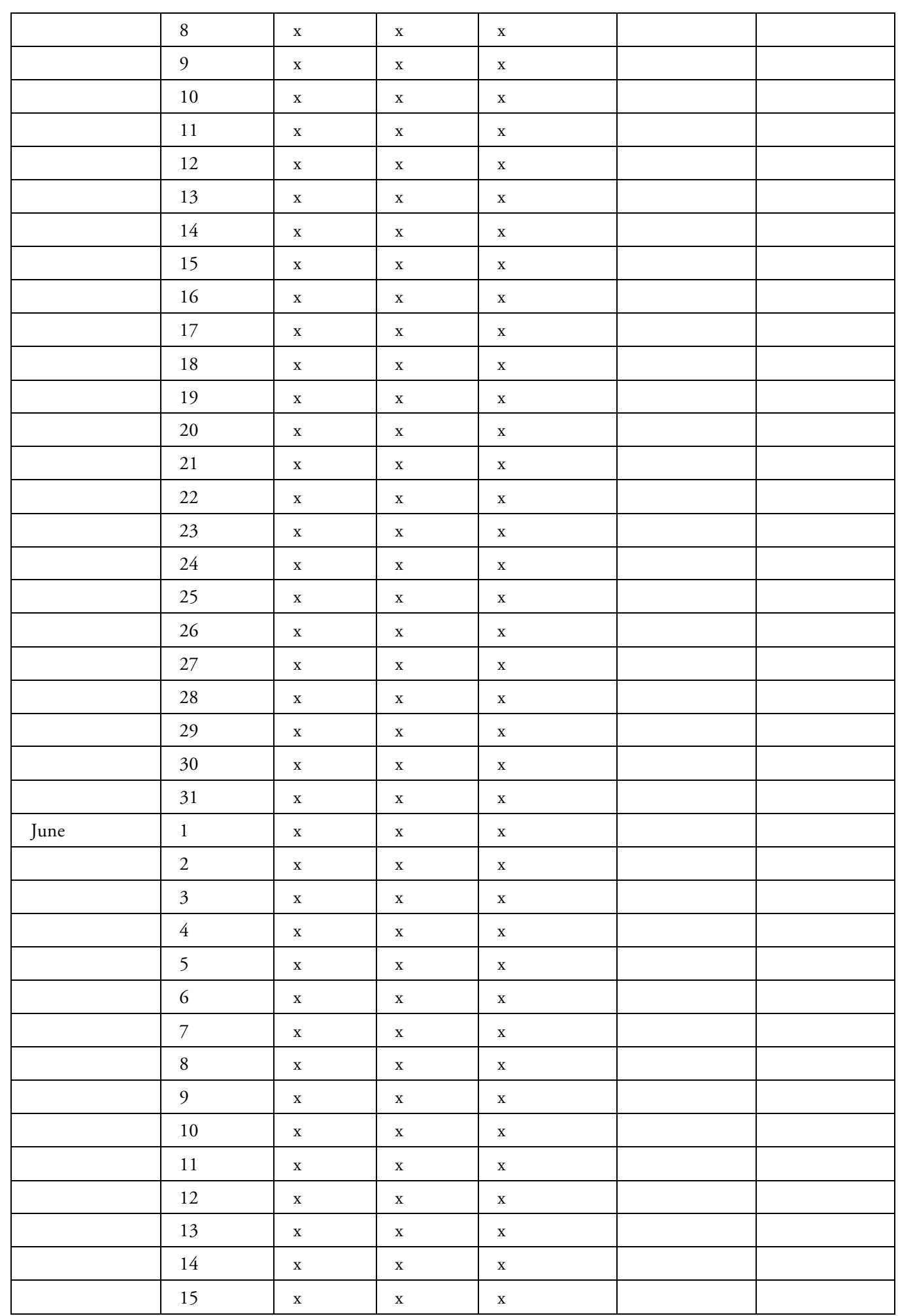

Studies in Digital Heritage, Vol. 1, No. 1, Article 2, Publication date: March 2017 


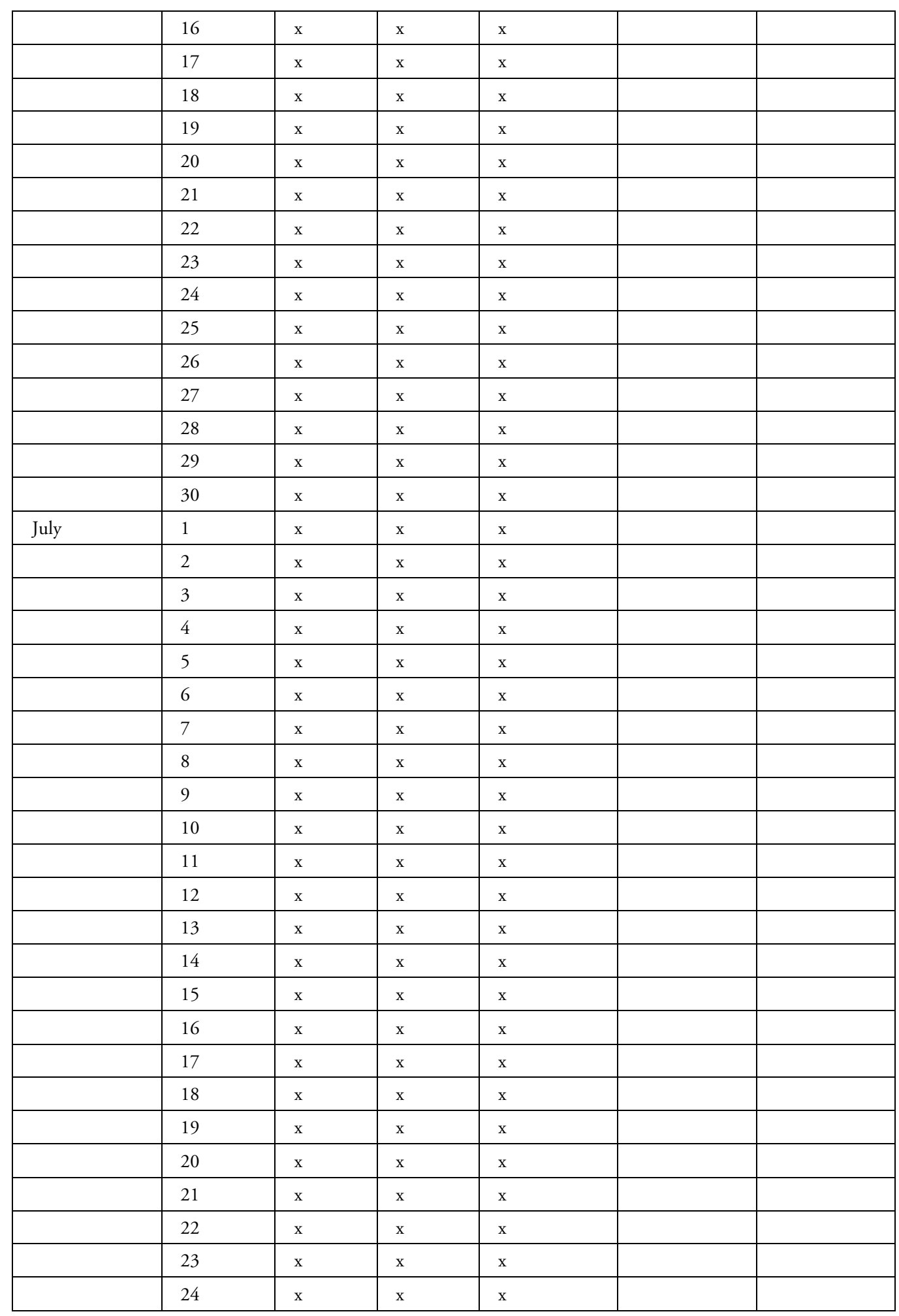


The Relationship between the Montecitorio Obelisk and the Ara Pacis 1:107

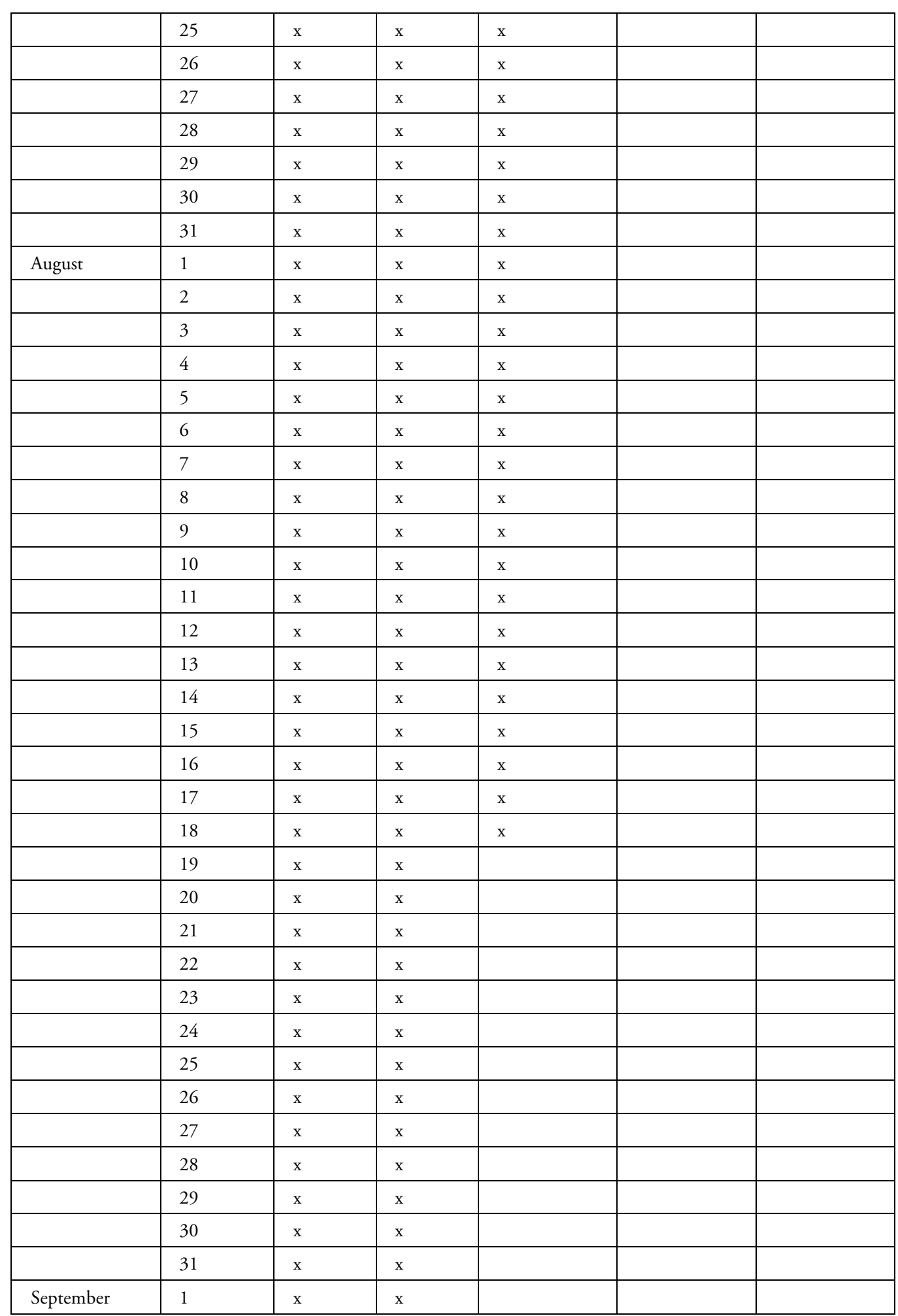

Studies in Digital Heritage, Vol. 1, No. 1, Article 2, Publication date: March 2017 


\begin{tabular}{|c|c|c|c|c|c|}
\hline & 2 & $\mathrm{x}$ & $\mathrm{x}$ & & \\
\hline & 3 & $\mathrm{x}$ & $\mathrm{x}$ & & \\
\hline & 4 & $\mathrm{x}$ & $\mathrm{x}$ & & \\
\hline & 5 & $\mathrm{x}$ & $\mathrm{x}$ & & \\
\hline & 6 & $\mathrm{x}$ & $\mathrm{x}$ & & \\
\hline & 7 & $\mathrm{x}$ & $\mathrm{x}$ & & \\
\hline & 8 & $\mathrm{x}$ & $\mathrm{x}$ & & \\
\hline & 9 & $\mathrm{x}$ & $\mathrm{x}$ & & \\
\hline & 10 & $\mathrm{x}$ & $\mathrm{x}$ & & \\
\hline & 11 & & $\mathrm{x}$ & & \\
\hline & 12 & & $\mathrm{x}$ & & \\
\hline & 13 & & $\mathrm{x}$ & & \\
\hline & 14 & & $\mathrm{x}$ & & \\
\hline & 15 & & $\mathrm{x}$ & & \\
\hline & 16 & & $\mathrm{x}$ & & \\
\hline & 17 & & $\mathrm{x}$ & & \\
\hline & 18 & & $\mathrm{x}$ & & \\
\hline & 19 & & $\mathrm{x}$ & & \\
\hline & 20 & & $\mathrm{x}$ & & \\
\hline & 21 & & $\mathrm{x}$ & & \\
\hline & 22 & & $\mathrm{x}$ & & \\
\hline & 23 & & $\mathrm{x}$ & & \\
\hline & 24 & & $\mathrm{x}$ & & \\
\hline & 25 & & $\mathrm{x}$ & & \\
\hline & 26 & & $\mathrm{x}$ & & \\
\hline & 27 & & $\mathrm{x}$ & & $\mathrm{x}$ \\
\hline & 28 & & & & $\mathrm{x}$ \\
\hline & 29 & & & & $\mathrm{x}$ \\
\hline & 30 & & & & $\mathrm{x}$ \\
\hline \multirow[t]{10}{*}{ October } & 1 & & & & $\mathrm{x}$ \\
\hline & 2 & & & & $\mathrm{x}$ \\
\hline & 3 & & & $\mathrm{x}$ & $\mathrm{x}$ \\
\hline & 4 & & & $\mathrm{x}$ & $\mathrm{x}$ \\
\hline & 5 & & & $\mathrm{x}$ & $\mathrm{x}$ \\
\hline & 6 & & & $\mathrm{x}$ & $\mathrm{x}$ \\
\hline & 7 & & & $\mathrm{x}$ & $\mathrm{x}$ \\
\hline & 8 & & & $\mathrm{x}$ & $\mathrm{x}$ \\
\hline & 9 & & & $\mathrm{x}$ & $\mathrm{x}$ \\
\hline & 10 & & & $\mathrm{x}$ & $\mathrm{x}$ \\
\hline
\end{tabular}


The Relationship between the Montecitorio Obelisk and the Ara Pacis 1:109

\begin{tabular}{|l|l|l|l|l|l|l|}
\hline & 11 & & & & $x$ & $x$ \\
\hline & 12 & & & & $x$ & $x$ \\
\hline & 13 & & & & $x$ & $x$ \\
\hline & 14 & & & & $x$ & $x$ \\
\hline & 15 & & & & $x$ & $x$ \\
\hline & 16 & & & & $x$ & $x$ \\
\hline & 17 & & & & & $x$ \\
\hline & 18 & & & & & $x$ \\
\hline & 19 & & & & & $x$ \\
\hline & 20 & & & & & $x$ \\
\hline & 21 & & & & & $x$ \\
\hline
\end{tabular}

Studies in Digital Heritage, Vol. 1, No. 1, Article 2, Publication date: March 2017 


\section{APPENDIX II - OVERVIEW OF THE VIRTUAL MERIDIAN OF AUGUSTUS AND THE CELESTIALENGINE}

John Fillwalk

Cultures throughout history have endeavored to understand the passage of time, discovering numerous approaches to mark and impart celestial significance into their environments. Archaeo-astronomers over the last several centuries have been engaged in the process of establishing a record of these techniques-decoding approaches and meaning in the potential celestial alignments of the structures of ancient peoples. Until recently, a scholar studying such alignments would need to travel to a remote physical site and apply the field tools of archaeology, surveying, and engineering to understand such phenomena. Carefully observed drawings, photographs, algorithms and measurements recorded on the dates and times of the study would have to be directly noted. With the aid of 3D modeling, virtual environments and celestial databases this process can be simulated, providing a dynamic and accurate framework of inquiry to rapidly establish potential candidates for further scholarly study. The data derived from the identified targets can then be further analyzed by specialists who can quickly begin the process of establishing significance as a celestial alignment.

IDIA Lab's CelestialEngine was designed to an evolving set of specifications mainly provided by Bernard Frischer resulting from his use of the simulation in the period 2011 to 2017 as a tool for research to assess the validity of Edmund Buchner's theory about the nature of the gnomonic instrument and the relationship of the Montecitorio Obelisk to the Ara Pacis. The simulator creates a digital representation of solar, lunar, and planetary objects as they are referenced in relation to terrestrial positioning over a span of time. The CelestialEngine was thus a key component of the Virtual Meridian of Augustus, a simulation authored in the game engine Unity specifically for this study.

After importing an accurately measured, scaled, and constructed 3D model into the simulator, the positional coordinates of the site must be calibrated. This includes obtaining precise longitude, latitude, altitude, scale and orientation of the structure(s) in relation to geographic north. Once this referencing process has taken place, ephemerides from the Horizons database (Jet Propulsion Laboratory, NASA. http://ssd.jpl.nasa.gov/ ?horizons) are integrated within the simulator. These data inform the positioning of the virtual celestial objects (proxy sun, moon or planets). In the case of the present study, the 3D model utilized was jointly developed by the IDIA Lab and by Matthew R. Brennan of the Virtual World Heritage Laboratory in collaboration with project director Bernard Frischer. Key elements in AutoCad were furnished by archaeologist-surveyors Ismini Miliaresis and Adalberto Ottati as well as by gnomonist Paolo Albèri Auber. The position of the Ara Pacis reflects Moretti 1948; the position of the section of the meridian at Via di Campo Marzio 48 corresponds to where Ottati and Miliaresis surveyed it (see Frischer forthcoming); and the position of the obelisk was determined using the data and methodology outlined by Frischer in this paper.

The Horizons System itself can generate positional data on 660,515 celestial features, including 3,298 comets, 178 planetary satellites, 8 planets, and the sun. The CelestialEngine is designed to accept any JPL provided ephemeris, driving and dynamically updating the real time-positioning of a $3 \mathrm{D}$ proxy celestial object within the virtual simulator.

Two modes of CelestialEngine have been developed and are employed depending on the requirements of a scope of study. In the case of an archaeo-astronomical project that requires a limited range of years and dates, such as 
in the Virtual Meridian of Augustus, we scrape that specific dataset and build it into the simulation, baking it into the published project. This provides an immediate response in entering various dates and times in the study of an alignment. In some simulations, however, such as in our Virtual Stonehenge project, the years of interest span millennia and involve multiple celestial objects, requiring real-time and dynamic access at the request of the investigator. Depending on network speed, this may cause a slight delay as the ephemerides are returned and the simulation's virtual celestial objects are updated. The advantage of the scraped data approach is that the simulation is self-contained and does not require a live network connection. The disadvantage of the scraping method is in factors limiting performance, since the load times and file size of the build increase with greater amounts of data.

The February 2017 version of the Virtual Meridian Augusti simulation includes several updates and features. The project was ported away from Unity's web browser plugin-based webplayer system to the new standard that is based in WebGL and executable versions. A stand-alone executable was also created which (alongside the WebGL version) employed a new Unity 5.5 lighting scheme and a Unity-based (instead of image-based) dynamic skybox. Also significant is the development of a Stellarium plugin, which allows us to toggle between Unity and Stellarium skyboxes. This gives an investigator the ability to bring in the visible planets, stars, sun, moon and comets to potentially discover other celestial alignments using the power of Stellarium merged with the 3D capabilities of Unity.

The methods that we designed for CelestialEngine to access Horizons could potentially be connected to any live 3D simulation environment to visually represent the spatial relationships of interest to archaeo-astronomers. In almost all of our celestial heritage simulations, however, we have integrated Unity 3D as the simulation environment. Unity is a platform-agnostic game engine and integrated development environment that allows developers to create dynamic virtual simulations for the web, various desktop platforms, game consoles and iOS and Android-based devices.

In the instance of a project that requires a dynamic request of celestial ephemerides, we employ a method in Unity that calls out to a URL and returns new data into the simulator. The CelestialEngine code then inspects the request to see if it has completed before refreshing and advancing the simulation. The advantage of this modality is that a scholar or student can make a request for any date or time within any frame of interest. The Horizons dataset spans the years from 9999 BC to AD 9999.

Within the simulation, the virtualized celestial objects must be referenced to the $3 \mathrm{D}$ geometries representing the virtual site. The celestial proxy objects are positioned in the virtual sky dome, which is scripted to be driven by the JPL data. The spheres or planes of the proxies are set so as always to face the perspective of the virtual observer. This creates a phenomenological problem, since, in physical reality, celestial objects are effectively at an infinite distance relative to a terrestrial observer. Any distance traveled within the scope of even a vast terrestrial site results in an insignificant change in observational angle. This is not the case in a $3 \mathrm{D}$ virtual simulation. If a virtual observer translates his position by even a small amount of distance, the angle of observation relative to the viewer and virtual object changes significantly. To overcome this phenomenon, a method had to be developed to effectively represent the viewer/object relationship continuously at infinity. This effect is accomplished within the simulation by parenting the virtual object to the viewer's camera or avatar. As the virtual observer changes his position, the proxy objects within the celestial sphere update with the new translation coordinates, thus maintaining the appropriate relationship of effective infinity. 
CelestialEngine has been employed in numerous IDIA Lab archaeo-astronomical studies that have included sites from various periods and cultures, including several UNESCO World Heritage sites. One of our projects, Virtual Stonehenge, a simulation created for the History Channel's The Universe series, investigates both lunar and solar alignments of the monument over the span of centuries of its phased development. In another study, IDIA Lab worked with Bernard Frischer and the Virtual World Heritage Laboratory at Indiana University on a complex virtual world and celestial study of Hadrian's Villa, in which investigators could examine suspected alignments of the expansive virtual restored site from any vantage point. Visitors to our Virtual Chichen Itza can study potential solar alignments along and across the axis of the ball court site. Other projects have included a lunar alignment simulation of the Temple of Artemis at Ephesus and Virtual Izapa, a Mayan site where its Group F ball court complex has a well-known solstice alignment and is considered to be the origin of the development of the Mayan Long Count Calendar.

It is the goal of virtual simulation technologies like CelestialEngine to enhance processes that might not be feasible or even possible with conventional tools of investigation, research, and measurement typically used in the sciences and humanities. 


\section{BIBLIOGRAPHY}

Stefania Adamo Muscettola. 2001. Pozzuoli, Serapide, Settimio Severo. In Atti del V Congresso Internazionale ItaloEgiziano, Faraoni come dei. Tolemei come Faraoni, Riassunti, Torino, Archivio di Stato, 9-23 Dicembre 2001, Torino, 325-333.

Paolo Albèri Auber. 2011-2012. L'Obelisco di Augusto in Campo Marzio e la sua Linea Meridiana. Aggiornamenti e proposte. Rendiconti della Pontificia Accademia Romana di Archeologia, 84 (2011-2012), 153- 285.

Paolo Albèri Auber. 2013a. La linea meridiana di Augusto. Orologi Solari, no. 2, CGI Coordinamento Gnomonico Italiano, August, 2013, 5-19.

Paolo Albèri Auber. 2013b. The Obelisk of Augustus and its Meridian Line. Part 1. The Compendium. Journal of the North American Sundial Society, September, 2013, 24-31.

Paolo Albèri Auber. 2014. Reconstructing the Montecitorio Obelisk of Augustus: A Gnomonist's Point of View. In Lothar Haselberger, ed. 2014. The Horologium of Augustus: Debate and Context. Journal of Roman Archaeology Suppl. Portsmouth (RI), 2014, 63-76.

Maurice Alliot. 1949-54. Le culte d'Horus à Edfou au temps des Ptolemées. 2 vols., Cairo: Imprimerie de l'Institut français d'archéologie orientale.

Jan Assmann. 1983. Re und Amun: die Krise des polytheistischen Weltbilds im Ägypten der 18-20 Dynastie. Orbis Biblicus et Orientalis 51, Göttingen: Universitätsverlag.

Jan Assmann. 2006, Ma'at: Gerechtigkeit und Unsterblichkeit im alten Ägypten, München: Beck 2006.

John Baines. 1970. Bnbn: Mythological and Linguistical Notes, Orientalia 39 (1970), 389-404.

Angelo Maria Bandini, et al. 1750. De obelisco Caesaris Augusti e Campi Martii ruderibus nuper eruto commentarius, Rome: Ex typographia Palladis.

Alessandro Barchiesi. 2009. Phaethon and the Monsters. In P. Hardie, ed. Paradox and the Marvellous in Augustan Literature and Culture, Oxford: Oxford University Press, 163-188.

Paul Barguet. 1950. L'obélisque de Saint-Jean-de-Latran dans le temple de Ramsès II a Karnak. Annales du Service des Antiquités de l'Égypte 50 (1950), 269-280.

Lanny Bell. 2002. Divine Kingship and the Theology of the Obelisk Cult in the Temples of Thebes. In Horst Beinlich, et al. eds., 5. Ägyptische Tempeltagung, Würzburg, 23.-26. September 1999, Akten der Ägyptologische Tempeltatungen ÄAT 33.3, Wiesbaden, 17-46.

Juan Antonio Belmonte et al. 2009. Unveiling Seshat: New Insights into the Stretching of the Cord Ceremony. In Juan Antonio Belmonte, Mosalam Shaltout, eds. In Search of Cosmic Order: Selected Essays on Egyptian Archaeoastronomy. Cairo: American University in Cairo Press, 197-212.

Amin Benaissa. 2013. Ammianus Marcellinus Res Gestae 17.4.17 and the Translator of the Obelisk in Rome's Circus Maximus. Zeitschrift für Papyrologie und Epigraphik 186 (2013), 114-118.

Janice M. Benario. 1960. Book 4 of Horace's Odes: Augustan Propaganda. Transactions of the American Philological Association 91 (1960), 339-352.

Jean Béranger. 1975. La 'prévoyance' (providentia) impériale et Tacite, Annales, I,8. In François Paschoud and Pierre Ducrey, eds., Principatus. Etudes de notions et d'histoire politiques dans l'antiquité gréco-romaine, Geneva: Librairie Droz, 331-352.

Dietrich Berges. 1995. Herrscherkult und Kultgerät. Antike Kunst 38 (1995), 92-104.

Marianne Bergmann. 1998. Die Strahlen der Herrscher. Theomorphes Herrscherbild und politische Symbolik im Hellenismus und in der römischen Kaiserzeit, Mainz: Philipp von Zabern.

Robert S. Bianchi. 1988. Cleopatra's Egypt. Age of the Ptolemies, Brooklyn (NY): The Brooklyn Museum of Art.

Peter Bing. 1988. The Well-Read Muse. Present and Past in Callimachus and the Hellenistic Poets. Hypomnemata 90, Göttingen: Vandenhoeck und Ruprecht.

John Bodel. 1999. Punishing Piso. American Journal of Philology 120 (1999), 42-63.

Axel Boethius 1935. Das Stadtbild im spätrepublikanischen Rom. Acta instituti romani regni Sueciae 4, Opuscula Archaeologica 1, Lund, 164-195. 
Axel Boethius. 1948. Three Roman Contributions to World Architecture. In Festskrift J.A. Hedvall, Göteborg: Elands Boktryckeri, 59-74.

Peter Cornelis Bol et al., eds. 2004. Fremdheit - Eigenheit. Ägypten, Griechenland und Rom, Austausch und Verständnis. Städel-Jahrbuch N. F. 19.

Hans Bonnet. 1952. Reallexikon der ägyptischen Religionsgeschichte, Berlin: De Gruyter.

Dietrich Boschung. 2002. Gens Augusta. Untersuchungen zu Aufstellung, Wirkung und Bedeutung der Statuengruppen des julisch-claudischen Kaiserhauses, Mainz: Philipp von Zabern.

Evaristo Breccia. 1911. Iscrizioni greche e latine, Cairo: Imprimerie de l'Institut français d'archéologie orientale.

Frank Brown. 1967. Roman Architecture, New York: Braziller.

Philippe Bruneau. 1995. L'autel de cornes à Délos. Comptes rendus des séances de l'Académie des Inscriptions et BellesLettres 139 (1995) 321-339.

Edmund Buchner. 1976. Solarium Augusti und Ara Pacis. Römische Mitteilungen 83 (1976), 19-65.

Edmund Buchner. 1980. Horologium Solarium Augusti. Bericht über die Ausgrabungen 1979/80. Römische Mitteilungen 87 (1980), 355-373.

Edmund Buchner. 1982a. Die Sonnenubr des Augustus, Mainz: Verlag Phillip von Zabern.

Edmund Buchner. 1982b. L'orologio solare di Augusto. Rendiconti della Pontificia Accademia Romana di Archeologia 5354 (1980-82), 331-345.

Edmund Buchner. 1983. Horologium Augusti. Neue Ausgrabungen in Rom. Gymnasium 90 (1983), 494-508.

Edmund Buchner. 1984. Sonnenuhr des Augustus und römischer Fuß. In Bauplanung und Bautheorie der Antike, Diskussionen zur Archä̈logischen Bauforschung 4, 215-219.

Edmund Buchner. 1988. Horologium solarium Augusti. In Kaiser Augustus und die verlorene Republik (exhibition catalogue, Berlin), 240-245.

Edmund Buchner. 1993-1994. Neues zur Sonnenuhr des Augustus. Nürnberger Blätter zur Archäologie 10 (1993-1994), 77-84.

Edmund Buchner. 1996a. Horologium Augusti. In Eva Margarete Steinby, ed. Lexicon Topopographicum Urbis Romae 3 , Rome: Edizioni Quasar, 35-37.

Edmund Buchner. 1996b. Ein Kanal für Obelisken. Neues vom Mausoleum des Augustus in Rom. Antike Welt 27 (1996), 161-168.

Edmund Buchner. 1999. Horologium Augusti. In Cesare D’Onofrio, ed. Via del Corso. Una strada lunga 2000 anni (exhibition catalogue, Rome) 159-163.

Giacomo Calandra di Roccolino. 2007. Ara Pacis: fonti numismatiche. Engramma 58 (June-August 2007). Published online at: http://www.engramma.it/engramma_revolution/58/058_saggi_calandra.html (seen January 29, 2017).

Alan Cameron. 1995. Callimachus and his Critics, Princeton: Princeton University Press.

Maria Cristian Capanna. 2013. Regione VII. Via Lata. In Andrea Carandini with Paolo Carafa, eds. Atlante di Roma Antica. Biografia e ritratti della città, Milan: Electa, 477-492.

Gianfilippo Carettoni. 1983. Das Haus des Augustus auf dem Palatin, Mainz: Philipp von Zabern.

Ferdinando Castagnoli. 1971. Orthogonal Town Planning in Antiquity, Cambridge, MA: MIT Press.

David Castriota. 1995. The Ara Pacis Augustae and the Imagery of Abundance in Later Greek and Early Roman Imperial Art, Princeton: Princeton University Press.

Sylvie Cauville and Didier Devauchelle. 1984. Le temple d'Edfou: Étapes de la construction et nouvelles données historiques. Revue d'Egyptologie 35 (1984), 31-55.

Monica Centanni and Maria Grazia Ciani. 2007. Ara Pacis Augustae: le fonti letterarie. Engramma 58. Published online at: http://www.engramma.it/engramma_revolution/58/058_saggi_centanniciani.html (seen January 29, 2017).

Martin Percival Charlesworth, "Providentia and Aeternitas," The Harvard Theological Review 29 (1936) 107-132.

Emile Chassinat and Sylvie Cauville. 1990. Le temple d'Edfou, II, Cairo: Institut français d'archéologie orientale.

Henri Chevrier. 1949. Rapport sur les travaux de Karnak 1948-1949. Annales du service des antiquités de l'Égypte 49 (1949), 241-267. 
Emanuele Marcello Ciampini. 2004. Gli obelischi iscritti di Roma, Rome: Poligrafico e Zecca dello Stato. Amanda Claridge. 2010. Rome: An Archaeological Guide, second edition, Oxford: Oxford University Press. John R. Clarke. 1991. The Houses of Roman Italy, 100 B.C. to 250 A.D. Berkeley: University of California Press.

Filippo Coarelli. 1983. Il Pantheon, l'apoteosi di Augusto e l'apoteosi di Romolo. In Città e architettura nella Roma imperiale, Atti del seminario del 27 ottobre 1981 nel 25 anniversario dell'Accademia di Danimarca, Analecta Romana, Supp. 10, Odense: Odense University Press, 41-46.

Filippo Coarelli. 2007. Rome and Environs. An Archaeological Guide, translated by James J. Clauss and Daniel P. Harmon, Berkeley: University of California Press.

Robert Cohon. 2015. Roman Metrics and Roman Sarcophagi. In Römische Sarkophage, Akten des internationalen Werkstattgesprächs, 11. - 13. Oktober 2012, Graz: Veröffentlichungen des Instituts für Klassische Archäologie der Karl-Franzens-Universität Graz, 74-91.

Jeffrey L. Collins. 2000. Obelisks as Artifacts in Early Modern Rome: Collecting the Ultimate Antiques. Ricerche di storia dell'arte 72 (2000), 49-68.

Brian A. Curran, Anthony Grafton, Pamela O. Long, and Benjamin Weiss. 2009. Obelisk: A History, Cambridge, MA: MIT Press.

Glen Dash. 2011. North by Northwest: The Strange Case of Giza's Misalignments. Dash Foundation. Published online at: http://www.DashFoundation.org/ North_by_Northwest.pdf (seen January 29, 2017).

Penelope J. E. Davies. 2000. Death and the Emperor: Roman Imperial Funerary Monuments, from Augustus to Marcus Aurelius, Cambridge: Cambridge University Press.

Attilio Degrassi. 1963. Inscriptiones Italiae, XIII (Fasti et Elogia) II, Rome: Istituto Poligrafico dello Stato, Libreria dello Stato.

Nancy de Grummond and Erika Simon, eds. 2006. The Religion of the Etruscans, Austin: University of Texas Press.

Waldemar Deonna. 1938. Le mobilier délien, Exploration archéologique de Délos : faite par l'École française d'Athènes, Paris: E. de Boccard.

Mariette de Vos. 1980. L'egittomania in pitture e mosaici romano-campani della prima età imperiale. Études Préliminaires aux Religions Orientales dans L'Émpire Romain 84, Leiden: Brill.

Cesare D’Onofrio. 1967. Gli obelischi di Roma, Rome: Bulzoni.

Elisha Ann Dumser, ed. 2002. Mapping Augustan Rome, directed by L. Haselberger in collaboration with D. G. Romano, Journal of Roman Archaeology, Supplement 50.

Gregory S. Dundas. 2002. Augustus and the Kingship of Egypt. Historia: Zeitschrift für Alte Geschichte 51 (2002), 433448.

Ian Du Quesnay. 1995. Horace Odes 4.5: Pro Reditu Imperatoris Caesaris Divi Filii Augusti. In S. J. Harrison, ed. Homage to Horace. A Bimillenary Celebration, Oxford: Oxford University Press, 128-187.

Victor Duruy. 1894. History of Rome and of the Roman People from Its Origin to the Invasion of the Barbarians, trans. from the French, vol. 4.1, Boston: Estes and Lauriat.

Werner Eck, et al. 1996. Das senatus consultum de Cn. Pisone patre, Vestigia 48, Munich: C. H. Beck.

Serena Ensoli and Eugenio La Rocca, eds. 2000. Aurea Roma. Dalla città pagana alla città cristiana, Rome: "L'Erma" di Bretschneider.

Diane Favro. 1996. The Urban Image of Augustan Rome, Cambridge: Cambridge University Press.

Duncan Fishwick. 2010. Agrippa and the Ara Providentiae at Rome. Zeitschrift für Papyrologie und Epigraphik 174 (2010), 251-258.

Bernard Frischer. 2008. From Digital Illustration to Digital Heuristics. In Bernard Frischer and Anastasia Dakouri-Hild, eds. Beyond Illustration: 2D and 3D Digital Technologies as Tools for Discovery in Archaeology, BAR International Series 1805, Oxford: British Archaeological Reports, v-xxiv.

Bernard Frischer and John Fillwalk. 2014. New Digital Simulation Studies on the Obelisk, Meridian, and Ara Pacis of Augustus. In Lothar Haselberger, ed. The Horologium of Augustus: Debate and Context. Journal of Roman Archaeology Supplement 99, 77-90.

Bernard Frischer. Forthcoming. Edmund Buchner's Solarium Augusti: New Observations and Simpirical Studies, with 
technical appendices by Paolo Albèri Auber, David Dearborn, John Fillwalk, Mika Kajava, and Stefano Floris, Rendiconti della Pontificia Accademia Romana di Archeologia.

Dieter Furth et al. 2004. Die Inschriften des Tempels von Edfou, Wiesbaden: Harrassowitz.

Karl Galinsky. 1967. Sol and the Carmen Saeculare. Latomus 26 (1967), 619-633.

Karl Galinsky. 1992. Venus, Polysemy, and the Ara Pacis Augustae. American Journal of Archaeology 96 (1992), 457-475.

Karl Galinsky 1996. Augustan Culture: An Interpretive Introduction, Princeton: Princeton University Press.

Karl Galinsky, K. 2013. La costruzione del mito augusteo: Some Construction Elements. In M. Labate and G. Rosati, eds., La costruzione del mito augusteo, Heidelberg: Universitätsverlag Winter, 29-48.

Marion Giebel. 1975. Augustus, Res gestae, Tatenbericht (Monumentum Ancyranum), Lateinisch, Griechisch und Deutsch, Stuttgart: Reclam.

Jean-Claude Goyon. 1988. Ptolemaic Egypt: Priests and the Traditional Religion. In Robert S. Bianchi, ed. Cleopatra's Egypt. Age of the Ptolemies, Brooklyn (NY): The Brooklyn Museum of Art, 29-39; German translation 1989: Das ptolemäische Ägypten: Priester und traditionelle Religion. In Dietrich Wildung; Sylvia Schoske, eds. Kleopatra : Ag̈pten um die Zeitenwende, Exhibition in the Kunsthalle der Hypo-Kulturstiftung, 16. Juni-10. September 1989, Mainz : Philipp von Zabern, 33-44.

Steven R. W. Gregory. 2012. The Obelisks of Augustus: The Significance of a Symbolic Element of the Architectural Landscape in the Transmission of Ideology from Egypt to Rome. Journal of Ancient Egyptian Interconnections 4 (2012), 9-30.

Jean-Claude Grenier. 1995. L'Empereur et le Pharaon. In Wolfgang Haase, ed. Aufstieg und Niedergang der römischen Welt, II.18.5, Berlin: De Gruyter, 3181-3194.

Pierre Gros. 1976. Aurea Templa: Recherches sur l'architecture religieuse de Rome à l'époque d'Auguste. Bibliothèque des Écoles françaises d'Athènes et de Rome 231, Rome: École française de Rome.

Jacqueline Calzini Gysens and Filippo Coarelli. 1999. Sol, Templum. In Eva Margareta Steinby, ed. Lexicon Topographicum Urbis Romae, vol. 4, Rome: Edizioni Quasar, 331-333.

Labib Habachi and Charles Cornell Van Siclen. 1977. The Obelisks of Egypt: Skyscrapers of the Past, New York: Scribner.

Chrystina Häuber. 2014. The Eastern Part of the Mons Oppius in Rome: The Sanctuary of Isis et Serapis in Regio III, the Temples of Minerva Medica, Fortuna Virgo and Dea Syria, and the Horti of Maecenas, with contributions by Edoardo Gautier di Confiengo and Daniela Velestino, Bullettino della Commissione Archeologica Comunale di Roma Supplement 22.

Chrystina Häuber. 2015. Rome: The City of Memories. Or, Why and How Reconstruct and Visualize Ancient and Post-antique Rome Using Digital Technologies? The "AIS ROMANA," Diachronic and Phase Maps of (Ancient) Rome in the WWW. Online at: https://epub.ub.uni-muenchen.de/24136/

Chrystina Häuber. 2016. Augustus' Rôle as Pharaoh of Egypt and Julius Caesar's Calendar Reform: The Montecitorio Obelisk, the Meridian Instrument and the Ara Pacis. In Frank Xaver Schütz and Chrystina Häuber, eds. FORTVNA Papers, vol. 2, 2016. Online at: http://www.rom.geographie.unimuenchen.de/publications/Augustus_Calendar_Obelisk_Rome.html

Robert Hannah. 2009. Time in Antiquity, London and New York: Routledge.

Lothar Haselberger. 2011. A Debate on the Horologium of Augustus. Journal of Roman Archaeology 24 (2011), 47-73.

Lothar Haselberger. 2014a. The 'Horologium': Where Do We Stand, and Where Should We Go? In Lothar Haselberger, ed. The Horologium of Augustus: Debate and Context. Journal of Roman Archaeology Supplement 99, 167201.

Lothar Haselberger, ed. 2014b. The Horologium of Augustus: Debate and Context. Journal of Roman Archaeology Supplement 99.

Gerald S. Hawkins. 1966. Astro-Archaeology. SAO Special Report\#226 (1966).

Emily A. Hemelrijk. 2007. Local Empresses: Priestesses of the Imperial Cult in the Cities of the Latin West. Phoenix 61 (2007), 318-349.

Friederike Herklotz. 2007. Prinzeps und Pharao - Der Kult des Augustus in Ägypten, Frankfurt/Main: Verlag Antike. Peter Heslin. Forthcoming. The Julian Calendar and the Solar Meridian of Augustus. Manuscript, 24 pages. 
Steven Hijmans. 2003. Sol Invictus, the Winter Solstice, and the Origins of Christmas. Mouseion 3 (2003), 377-398. Steven Hijmans. 2010. Temples and Priests of Sol in the City of Rome, Mouseion 10 (2010), 381-427.

Louise A. Hitchcock. 2002. Levantine Horned Altars: An Aegean Perspective on the Transformation of Socio-Religious Reproduction. In David M. Gunn, Paula M. Mcnutt, eds., 'Imagining' Biblical Worlds: Spatial, Soscial and Historical Constructs, Essays in Honor of James W. Flanagan, London and New York: Sheffield Academic Press, 223-239.

Günther Hölbl. 2000. A History of the Ptolemaic Empire, London: Routledge.

Günther Hölbl. 2004, Der römische Kaiser und das ägyptische Königtum. In Peter Cornelis Bol, Gabriele Kaminski, Caterina Maderna, eds. Fremdheit - Eigenheit. Ägypten, Griechenland und Rom, Austausch und Verständnis, StädelJahrbuch N. F. 19 (2004), 525-535.

Niklas Holzberg. 2009. Horaz. Dichter und Werk, Munich: C.H. Beck.

Erik Hornung. 1992. Idea into Image: Essays on Ancient Egyptian Thought, New York: Timken.

Carolus Hosius, ed. 1903. A. Gellii Noctium Atticarum Libri XX, vol. 1, Leipzig: B.G. Teubner.

Giulio Iacopi. 1973, Il santuario della Fortuna Primigenia e il Museo Archeologico Prenestino, fourth edition, Roma: Istituto Poligrafico dello Stato.

Irene Iacopi. 2007. La casa di Augusto: le pitture, Milan: Mondadori.

Erik Iversen. 1968. Obelisks in Exile, 2 vols., Copenhagen: G. E. C. Gad.

Guido Kaschnitz von Weinberg. 1944. Vergleichende Studien zur italisch-römischen Struktur. Römische Mitteilungen 59 (1944), 89-128.

David H. Kelly and Eugene F. Milone, 2011. Exploring Ancient Skies. A Survey of Ancient and Cultural Astronomy, second edition, New York, Dordrecht, Heidelberg, London: Springer.

Fred S. Kleiner. 1988. The Arch in Honor of Gaius Octavius and the Fathers of Augustus. Historia 37 (1988), 37-47.

David Klotz. 2008. Domitian at the Contra-Temple of Karnak. Zeitschrift für Ägyptische Sprache 135 (2008), 63-77.

Ludwig Koenen. 1983. Die Adaptation ägyptischer Königsideologie am Ptolemäerhof. In Edmond Van' t Dack, Peter Van Dessel, and Wilfried Van Gucht, eds. Egypt and the Hellenistic World, Studia Hellenistica 27, 143-190.

Eugenio La Rocca. 1999. Ara Pacis Augustae. In C. D’Onofrio, ed. Via del Corso. Una strada lunga 2000 anni, Rome: De Luca Editori d'Arte, 153-158.

Eugenio La Rocca. 2014. Augustus' Solar Meridian and the Augustan Urban Program in the Northern Campus Martius: An Attempt at a Holistic View. In Lothar Haselberger, ed. The Horologium of Augustus: Debate and Context. Journal of Roman Archaeology Supplement 99, 121-165.

Bérénice Lambrecht. 2001. L’Obélisque d'Hermapion. Le Muséon: Revue d'études orientales 114 (2001), 51-95.

Wolfgang Dieter Lebek. 1988. Augustalspiele und Landestrauer (Tab. Siar. Frg. II Col. A 11 -14). Zeitschrift für Papyrologie und Epigraphik 75 (1988), 59-71.

Mark Lehner. 1985. Giza. Archiv für Orientforschung 32 (1985), 136-158.

Christian Leitz. 1989. Studien zur ägyptischen Astronomie, Wiesbaden: O. Harrassowitz.

Christian Leitz. 1994. Tagewählerei, das Buch h3t nhh ph.wy dt und verwandte Texte, Ägyptologische Abhandlungen 55, Wiesbaden.

Christian Leitz, ed. 2002. Lexikon der ägyptischen Götter und Götterbezeichnungen, 7 vols., Orientalia Lovaniensia Analecta vols. 110-116, Leuven: Peeters.

Carl Richard Lepsius. 1849. Denkmäler aus Ägypten und Äthiopien, vol. 4, Berlin: Nicolaische Buchhandlung.

Paolo Liverani. 2004. Arco di Onorio. Arco di Portogallo. Bullettino della Commissione Archeologica Comunale di Roma 105 (2004), 351-370.

Paolo Liverani. 2006-2007. Templa duo nova Spei et Fortunae in Campo Marzio. Rendiconti della Pontificia Accademia Romana di Archeologia 79 (2006-2007), 291-314.

Paolo Liverani. Forthcoming. Urbanism and the Countryside. Rome. In Leonard Rutgers, Jodi Magness, Neil Christie, Robin Jensen, eds. The Cambridge Encyclopedia of Late Antique Art and Archaeology, Cambridge: Cambridge University Press.

John Bert Lott. 2014-2015. The Earliest Augustan Gods Outside Rome. Classical Journal 110 (2014-15), 129-158.

Kevin Lynch. 1959. The Image of the City, Cambridge, MA: MIT Press. 
George MacKay. 1894. Blinding of the Retina by Direct Sunlight. Opthalmic Review 13 (1894), 1-20, 41-57, and 83-96. David Magie, ed. and trans. 1982. Scriptores Historiae Augustae, 3 vols., Cambridge, MA and London: Harvard University Press.

Giulio Magli. 2009. Akhet Khufu: Archaeo-astronomical Hints at a Common Project of the Two Main Pyramids of Giza, Egypt. Nexus Network Journal - Architecture and Mathematics 11 (2009), 35-50.

Giulio Magli. 2016. The Gize 'Written’ Landscape and the Double Project of King Khufu. Time and Mind 9 (2016) 5774.

Giulio Magli. 2017. Archaeoastronomy in the Khmer Heartland. Studies in Digital Heritage 1 (2017), 1-16.

John Miller. 2009. Apollo, Augustus, and the Poets, Cambridge: Cambridge University Press.

Wilhelmus Hendrikus Mineur. 1984. Callimachus, Hymn to Delos. Introduction and Commentary. Mnemosyne Supplement 83, Leiden: Brill.

Giuseppe Moretti. 1939. Lo scavo e la ricostruzione dell'Ara Pacis Augustae. Capitolium 13 (1938) 479-490.

Giuseppe Moretti. 1948. Ara Pacis Augustae, 2 vols., Rome: Libreria dello Stato.

Jackie Murray. 2014. Anchored in Time: The Date in Apollonius' Argonautica. In Annette Harder, R. F. Regtuita and G. C. Wakker, eds. Hellenistic Poetry in Context. Hellenistica Groningana 20, Leuven: Peeters, 247-284.

Luisa Musso. 2000. Governare il tempo naturale provvedere alla felicitas terrena presiedere l'ordine celeste. Il Tempo con lo zodiaco: percorso, metamorfosi e memoria di un tema iconografico. In Serena Ensoli and Eugenio La Rocca, eds. Aurea Roma. Dalla città pagana alla città cristiana, Rome: "L'Erma” di Bretschneider, 373-388.

Georges Nachtergael. 1998. Un sacrifice en l'honneur de 'Baubo': scènes figurées sur un moule cubique se l'Égypte romaine. In Willy Clarysse, Antoon Schoors, Harco Willems, eds. Egyptian Religion: The Last Thousand Years. Studies Dedicated to the Memory of Jan Quaegebeur, Leuven: Peeters, 159-170.

Edouard Naville and Francis Llewellyn Griffith. 1890. The Mound of the Jew and the City of Onias, The Egypt Exploration Fund, vol. 7, London: Kegan Paul, Trench, Trubner \& Co.

Robert George Murdoch Nisbet. 2007. Horace: Life and Chronology. In Stephen J. Harrison, ed. The Cambridge Companion to Horace, Cambridge: Cambridge University Press, 7-21.

Carlos Noreña. 2013. Locating the Ustrinum of Augustus. Memoirs of the American Academy in Rome 58 (2013), 51-64.

David Noy. 2004. Being an Egyptian in Rome: Strategies of Identity Formation. In Jürgen Zangenberg and Michael Labahn, eds. Christians As a Religious Minority in a Multicultural City, London: T\&T Clark International, 47-55.

Robert Palmer. 1990 Studies of the Northern Campus Martius in Ancient Rome, Transactions of the American Philosophical Society, N.S. 80.2.

Enrico Paribeni. 1959. Catalogo delle sculture di Cirene, Rome: "L'Erma” di Bretschneider.

Grant Parker. 2003. Narrating Monumentality: The Piazza Navona Obelisk. Journal of Mediterranean Archaeology A 16.2 (2003), 193-215.

Grant Parker. 2007. Obelisks Still in Exile: Monuments Made to Measure. In Laurent Bricault, Miguel J. Versluys, Paul G. P. Meyboom, eds. Nile into Tiber: Egypt in the Roman World, Proceedings of the 3rd International Conference of Isis Studies, Faculty of Archaeology, Leiden University, May 11-14, 2005, Leiden: Brill, 209-222.

Stefan Pfeiffer. 2004. Das Dekret von Kanopos (238 v. Chr.). Kommentar und historische Auswertung eines dreisprachigen Synodaldekretes der ägyptischen Priester zu Ehren Ptolemaios' III. und seiner Familie, Munich: K. G. Sauer.

John Pollini. 1993a. The Gemma Augustea: Ideology, Rhetorical Imagery, and the Construction of a Dynastic Narrative. In Peter Holliday, ed. Narrative and Event in Ancient Art, Cambridge: Cambridge University Press, 258298.

John Polllini. 1993b. The Acanthus of the Ara Pacis as an Apolline and Dionysiac Symbol of Anamorphosis, Anakyklosis and Numen Mixtum. In M. Kubelik and M. Schwarz, edd. Von der Bauforschung zur Denkmalpflege, Festschrift für Alois Machatschek, Vienna: Phoibos-Verlag, 181-217.

John Pollini. 1995. The Augustus from Prima Porta and the Transformation of the Polykleitan Heroic Ideal. In Warren Moon, ed. Polykleitos, the Doryphoros, and Tradition, Madison: University of Wisconsin Press, 262-282.

John Pollini. 2012. From Republic to Empire: Rhetoric, Religion, and Power in the Visual Culture of Ancient Rome, 
Norman: Oklahoma University Press.

John Pollini. 2014. Some Observations on Augustus' Obelisk, Meridian, and Ara Pacis and Their Symbolic Significance in the 'Bildprogramm' of Augustus. In Lothar Haselberger, ed. The Horologium of Augustus: Debate and Context. Journal of Roman Archaeology Supplement 99 (2014), 53-61.

John Pollini. 2017. The Bronze Statue of Germanicus from Ameria (Amelia). American Journal of Archaeology 121.3 (forthcoming).

Reginald Stuart Poole. 1883. Catalogue of Greek coins. The Ptolemies, Kings of Egypt, Catalogue of the Greek Coins in the British Museum, London: Trustees of the British Museum.

David S. Potter, with a translation by Cynthia Damon. 1999. The Senatus consultum de Cn. Pisone patre. American Journal of Philology 120 (1999), 13-42.

Giuseppe Pulighe, Valerio Baiocchi, and Flavio Lupia. 2015. Horizontal Accuracy Assessment of Very High Resolution Google Earth Images in the City of Rome, Italy. International Journal of Digital Earth (2015). DOI: 10.1080/17538947.2015.1031716

Michael C. J. Putnam. 1986. Artifices of Eternity. Horace's Fourth Book of Odes, Ithaca and London: Cornell University Press.

Jan Quaegebeur. 1970. Ptolémée II en adoration devant Arsinoé II divinisée. Bulletin de l'Institut Français d'Archéologie Orientale 69 (1970), 191-217.

Jan Quaegebeur. 1993. L'autel-à-feu et l'abattoir en Égypte tardive. In Jan Quaegebeur, ed., Ritual and Sacrifice in the Ancient Near East. Proceedings of the International Conference Organized by the Katholieke Universiteit Leuven from the $17^{\text {th }}$ to the $20^{\text {th }}$ of April 1991, Orientalia Lovaniensia Analecta 55 (1993) 329-353.

Stephen Quirke. 2001. The Cult of Ra: Sun-Worship in Ancient Egypt, London: Thames \& Hudson.

Ellen Elizabeth Rice. 1983. The Grand Procession of Ptolemy Philadelphus, Oxford: Oxford University Press.

Lawrence Richardson, jr. 1992. A New Topographical Dictionary of Ancient Rome, Baltimore: Johns Hopkins University Press.

Herbert Rüdiger Ricke. 1965. Das Sonnenheiligtum des Königs Userkaf I: Der Bau, Cairo: Schweitzer Institut.

Charles Brian Rose. 1997. Dynastic Commemoration and Imperial Portraiture in the Julio-Claudian Period, Cambridge: Cambridge Univerity Press.

Orietta Rossini. 2012. Ara Pacis, Rome: Electa.

Linda Safran. 1993. Points of View: The Theodosian Obelisk Base in Context. Greek, Roman, and Byzantine Studies 34 (1993), 409-435.

Michele R. Salzman. 1990. On Roman Time: The Codex-Calendar of 354 and the Rhythms of Urban Life in Late Antiquity, London and Berkeley: University of California Press.

Michele R. Salzman. 2017. Aurelian and the Cult of Sol Invictus in the East and West. In Oren Tal and Zeev Weiss, eds. Expressions of Cult in the Southern Levant in the Greco-Roman Period. Manifestations in Text and Material Culture, Turnhout: Brepols.

Heinrich Schäfer. 1929. Die Sonne auf dem Obelisken. Orientalische Literaturzeitung 32/10 (1929), 721-726.

John Scheid and Henri Broise. 1980. Deux nouveaux fragments des actes des frères arvales. Mélanges de l'École française de Rome - Antiquité 92 (1980), 215-248.

John Scheid et al. 1998. Commentarii fratrum arvalium qui supersunt, Rome: École française de Rome.

Rolf Michael Schneider. 1997. Roma Aeterna - Aurea Roma. Der Himmelsglobus als Zeitzeichen und Machtsymbol. Kodikas-Code. Ars semeiotica. An International Journal of Semiotics 20 (1997), 103-133.

Rolf Michael Schneider. 2004. Nicht mehr Ägypten, sondern Rom: Der neue Lebensraum der Obelisken. Städel Jabrbuch N. F. 19 (2004), 155-179.

Rolf Michael Schneider. 2005. Römische Bildern äegyptischer Obelisken. In Herbert Beck, Peter Bol, Maraike Bückling, eds. Ägypten, Griechenland, Rom: Abwehr und Berührung, Tübingen: Ernst Wasmuth, 416-426.

Marlow Scholander. 1952. Trees, Lattices, and Betweenness, Proceedings of the American Mathematical Society 3 (1952), 369-381.

Michael Schütz. 1990. Zur Sonnenuhr des Augustus auf dem Marsfeld. Gymnasium 97 (1990), 432-457. 
Michael Schütz. 2011. The Horologium on the Campus Martius Reconsidered. Journal of Roman Archaeology 24 (2011), 78-86.

Daniel L. Selden. 1998. Alibis. Classical Antiquity 17 (1998), 390-404.

Mosalam Shaltout and Juan Antonio Belmonte. 2005. On the Orientation of Ancient Egyptian Temples: (1) Upper Egypt and Lower Nubia. Journal for the History of Astronomy 36 (2005), 273-298.

Mosalam Shaltout, Juan Antonio Belmonte, and Magdi Fekri. 2007. On the Orientation of Ancient Egyptian Temples: 3. Key Points at Lower Egypt and Siwa Oasis. Journal for the History of Astronomy 28 (2007), 413-442.

Robert K. Sherk. 1969. Roman Documents from the Greek East: Senatus Consulta and Epistulae to the Age of Augustus, Baltimore: Johns Hopkins University Press.

Magdalene Söldner. 2000. Fruchtbar im Sommer der Nil strömt voll erquickender Flut (Tibull 1, 7, 21 ff.). Ägyptenrezeption im augusteischen Rom. Antike Welt 31 (2000), 383-393.

Susan Sorek. 2010. The Emperors' Needles: Egyptian Obelisks and Rome, Exeter: Bristol Phoenix Press.

G. Soukassian. 1983. Les autels 'à cornes' ou 'a acrotères' en Egypte. Bulletin de l'Institut Français d'Archéologie Orientale 83 (1983), 317-333.

Susan Stephen. 2003. Seeing Double: Intercultural Poetics in Ptolemaic Alexandria, Berkeley: University of California Press.

Sasha Stern. 2012. Calendars in Antiquity: Empires, States, and Societies, Norman: University of Oklahoma Press.

Volker Michael Strocka. 1980. Augustus als Pharao. In Rolf A Stucky and Ines Jucker, eds., Eikones. Studien zum griechischen und römischen Bildnis. Hans Jucker zum sechzigsten Geburtstag gewidmet, Bern: Francke, 177-180.

James Stuart. 1750. De Obelisco Caesaris Augusti e Campo Martio Nuperrime Effosso. Epistola XIII. In Angelo Maria Bandini, ed. De Obelisco Caesaris Augusti e Campo Martio nuperrime effosso, Rome: Typographia Palladis, LXXIII$\mathrm{CV}$.

Molly Swetnam-Burland. 2010. Aegyptus Redacta: the Egyptian Obelisk in the Augustan Campus Martius. Art Bulletin 72 (2010), 135-153.

Molly Swetnam-Burland. 2011. 'Egyptian' Priests in Roman Italy. In Erich Gruen, ed. Cultural Identity and the Peoples of the Mediterranean, Los Angeles: Getty Research Institute, 336-353.

Molly Swetnam-Burland. 2015. Egypt in Italy: Visions of Egypt in Roman Imperial Culture, Cambridge, New York: Cambridge University Press.

Volker Michael Strocka. 1980. Augustus als Pharao. In Rolf A. Stucky and Ines Jucker, eds. Eikones : Studien zum griechischen und römischen Bildnis. Hans Jucker zum sechzigsten Geburtstag gewidmet, Bern: Francke, 177-180.

Hans Peter Syndikus. 1973. Die Lyrik des Horaz, 2 vols., Darmstadt: Wissenschaftliche Buchgesellschaft.

Lily Ross Taylor. 1931. The Divinity of the Roman Emperor, Ann Arbor: University of Michigan Press.

Richard Thomas. 2011. Horace Odes Book 4 and Carmen Saeculare, Cambridge: Cambridge University Press.

Dorothy Burr Thompson. 1973. Ptolemaic Oinochoai and Portraits in Faience. Aspects of the Ruler Cult, Oxford: Clarendon Press.

Vance Tiede. 2016. ARA · PACIS · AVGVSTAE: An Astro-archaeological Analysis. Mediterranean Archaeology and Archaeometry 16, no. 4 (2016), 267-274.

Mario Torellli. 1992. Topografia e iconologia. Arco di Portogallo, Ara Pacis, Ara Providentiae, Templum Solis. Ostraka 1 (1992), 105-131.

Mario Torelli. 1993. Arco di Portogallo. In Eva Margarete Steinby, ed. Lexicon Topographicum Urbis Romae, vol. 1, Rome: Edizioni Quasar, 77-79.

Mario Torelli. 1999a. Providentia, Ara. In Eva Margarete Steinby, ed. Lexicon Topographicum Urbis Romae, vol. 4, Rome: Edizioni Quasar, 165-166.

Mario Torelli. 1999b. Pax Augusta, Ara. In Eva Margarete Steinby, ed. Lexicon Topographicum Urbis Romae, vol. 4, Rome: Edizioni Quasar, 70-74.

Jennifer Trimble. 2007. Pharaonic Egypt and the Ara Pacis in Augustan Rome (September 2007). Princeton/Stanford Working Papers in Classics Paper No. 090701. Available at SSRN: https://ssrn.com/abstract=1426965 or 
http://dx.doi.org/10.2139/ssrn.1426965

Joyce Tyldesley. 2008. Cleopatra, Last Queen of Egypt, New York: Basic Books.

Roberto Valentini and Giuseppe Zucchetti, eds. 1940. Codice Topografico della Città di Roma, Rome: Tipografia del Senato.

Marike E. J. J. Van Aerde. 2013. Concepts of Egypt in Augustan Rome: Two Case Studies of Cameo Glass from the British Museum. British Museum Studies in Ancient Egypt and Sudan 20. Online at: http://www.britishmuseum.org/PDF/Aerde.pdf (seen September 7, 2015).

José M. Vásquez and Manuel Vaquero. 2009. The Sun Recorded Through History, Dordrecht: Springer.

Miguel John Versluys. Forthcoming. Haunting Traditions. The (Material) Presence of Egypt in the Roman World.

Hendrik Simon Versnel. 1970. Triumphus: An Inquiry into the Origin, Development and Meaning of the Roman Triumph, Leiden: Brill.

Paola Virgili and Paola Battistelli. 1999. Indagini in piazza della Rotonda e sulla fronte del Pantheon. Bullettino della Commissione Archeologica Comunale di Roma 100 (1999), 137-154.

Paola Virgili. 2006. Il Pantheon: scavo sulla fronte del tempio. In M. A. Tomei, ed., Roma. Memorie dal sottosuolo. Ritrovamenti archeologici 1980/2006, Rome: Electa, 167-169.

Giuseppina Capriotti Vittozzi. 2013. La terra del Nilo sulle sponde del Tevere, Collana di Studi di Egittolia e Civiltà Copta 1, Rome.

Peter H. von Blanckenhagen. 1954. The Imperial Fora. Journal of the Society of Architectural Historians 13 (1954), 21-26.

Armin von Gerkan. 1924. Griechische Städteanlagen. Untersuchungen zur Entwicklung des Städtebaus im Altertum, Berlin and Leipzig: Walter De Gruyter.

Lisa Vogel. 1973. The Column of Antoninus Pius, Cambridge, Mass.: Harvard University Press.

Gerald A. Wainwright. 1932. A Pair of Constellations. In Stephen Ranulph Kingdon Glanville, ed. Studies Presented to F. L. Griffith, London: Egypt Exploration Society, 373-383.

Wolfgang Waitkus. 1983. Anmerkungen zu der Verteilung der Dämonennamen aus TB 144/147 im Zweiwegebuch. Göttinger Miszellen 62 (1983), 79-83.

Susan Walker and Peter Higgs, eds. 2001. Cleopatra of Egypt: from History to Myth, Princeton: Princeton University Press.

Martin Wallraff. 2001. Christus Verus Sol: Sonnenverehrung und Christentum in der Spätantike, Münster: Aschendorff Verlag.

Alaric Watson. 1999. Aurelian and the Third Century, London and New York: Routledge.

P. Gregory Warden, Andrew Oliver, Pamela Crabtree, and Janet Monge. 1990. The Extramural Sanctuary of Demeter and Persephone at Cyrene, Libya: Final Reports. Part I: The Small Finds, University of Pennsylvania Museum Monograph 67.

Erik Welin. 1939. Die beiden Festtage der Ara Pacis Augustae. In Krister Hanell, ed. Dragma Martino P. Nilsson Dedicatum, Lund: H. Ohlsson, 500-513.

Karol Wight and Molly Swetnam-Burland. 2010. The Iconography of the Cameo Glass Flask at the J. Paul Getty Museum. Kölner Jahrbuch 43 (2010), 839-846.

Frederick J. Williams. 1978. Callimachus Hymn to Apollo: A Commentary, Oxford: Clarendon Press.

Dietrich Wildung and Sylvia Schoske, eds. 1989. Kleopatra: Ä̈ypten um die Zeitenwende, Exhibition in the Kunsthalle der Hypo-Kulturstiftung, 16. Juni-10. September 1989, Mainz: P. von Zabern.

Timothy Peter Wiseman. 2014a. Archaeology and History: The House of Augustus. Journal of Roman Archaeology 27 (2014), 546-551.

Timothy Peter Wiseman. 2014b. How Do We Know? Historical Evidence and Cartographic Data. In Chrystina Häuber, Franz X. Schütz, Gordon M. Winder, eds., Reconstruction and the Historic City: Rome and Abroad. An Interdisciplinary Approach, Beiträge zur Wirtschaftsgeographie München 6 (2014), 3-22.

Georg Wissowa. 1912. Religion und Kultus der Römer, Munich: C. H. Beck.

Jean Yoyotte. 1978. Apopis et la montagne rouge, Revue d'égyptologie 30 (1978), 147-150.

Jean Yoyotte. 1980-1981. Héra d'Héliopolis et le sacrifice humain. Annuaire de l'École Pratique des Hautes Études, Ve 
section 89 (1980-1981), 84-90.

Paul Zanker. 1987. Augustus und die Macht der Bilder, Munich: C. H. Beck.

Zbynek Zaba. 1953. L'orientation astronomique dans l'ancienne Egypte, et la précession de l'axe du monde, Prague: Academie tchecoslovaque des sciences.

Stephan Zink. 2012. Old and New Archaeological Evidence for the Plan of the Palatine Temple of Apollo. Journal of Roman Archaeology 25 (2012), 387-402. 